\title{
A TREATISE ON THE ACARINA, OR MITES.
}

\author{
By Nathan Banks, \\ Custodian of Arachnida.
}

\section{PREFACE.}

The mites have always attracted considerable interest, both from their minute size and because of the remarkable habits of many species. Although many have examined them in a desultory way, but few have really studied them. Consequently there is a great amount of literature by many persons, much of which is not reliable. Too often entomologists have considered that their knowledge of insects in general was a sufficient basis for the description of mites. Probably the lack of general works on mites has been responsible for many errors. For years the only work treating of the mites as a whole that has been accessible to American naturalists is Andrew Murray's Economic Entomology; Aptera. In this book, nearly 300 pages are devoted to Acarina. Unfortunately Murray's treatment is far from satisfactory and abundantly stored with mistakes, many, however, taken from other writer's.

Since that book was published several European specialists have been at work on the European fauna and produced monographs which are of great accuracy. Not only have many new facts been discovered, but many of the old facts have been given quite new interpretations. Such a belief as the parasitism of the Uropoda on the Colorado potatobeetle seems hardly as yet to have been eradicated. To present a reliable text to the American reader is my intention. Very frequently I have obtained many facts of importance and interest from the European literature; particularly is this true with those parasitic groups with which I am not so well acquainted. Errors will, of course, be found, but great care has been exercised in choosing the sources of information.

I have given tables to all the known American genera, and in some families added other well-known genera which will doubtless occur in our fauna when it is more thoroughly explored.

Practically the only door through which one may enter into the systematic study of mites in general is Canestrini's Prospetto dell'Acarofauna Italiana. 


\section{INTRODUCTION.}

The Acarians form an order in the great class Arachnida." They are thus related to spiders, daddy-long-legs, and scorpions. A few writers at various times have claimed that the mites were a separate class, but the best sense of modern authors is that they are genuine Arachnids, and in many ways closely related to Solpugids and Phalangids. Although quite easily recognized at sight, it is not so easy to give definite characters whereby to distinguish a mite from other Arachnids. The abdomen and cephalothorax are broadly united to each other, and often there is no distinction between these parts. Usually there is no trace of segmentation, but in some forms it is quite distinct. Eyes are often present, but rarely only a median pair as we

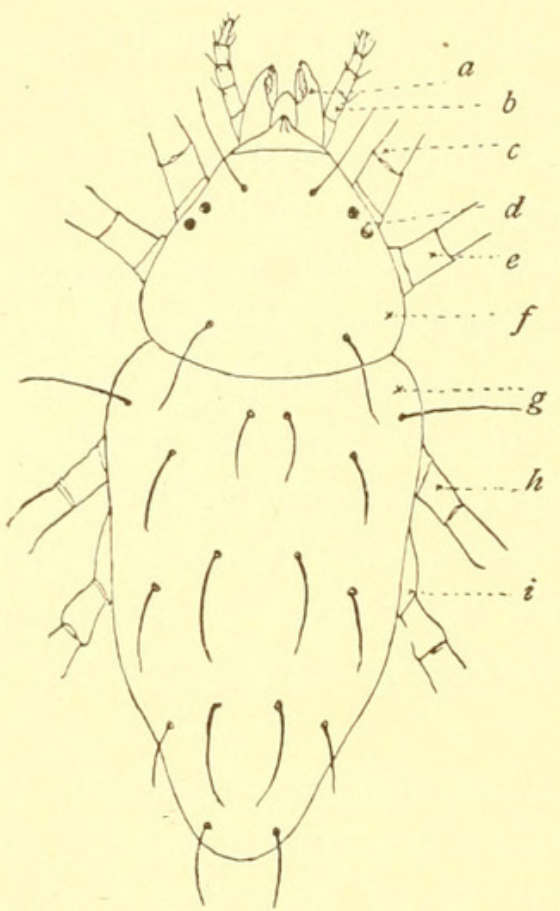

FIg 1.-DORSAL VIEW OF A MITE. $a$, MANDIBLES; $b$, PALPI; $c$, LEG I; $d$, EYES; $e$, LEG II; $f$, CEPHA LOTHORAX; $g$, ABDOMEN; $h$, LEG III; $i$, LEG IV. find in Phalangids and Solpugids. The mouth segments have become united to form a beak, rostrum, or capitulum. However this is not easily made out in some forms. Commonly the larva at birth has but three pairs of legs, and obtains the fourth pair only after a molt and metamorphosis. In the Eriophyidre, however, there are but two pairs of legs in both adult and young, and in Pteroptus the young have eight legs at birth. The adult mite has (except in the Eriophyidæ) four pairs of legs; often arranged in two groups, the hinder pairs apparently arising from the abdomen. However it is not probable that such is the case; rather the coalescence of the abdomen and cephalothorax has effaced the true outlines of these portions. It is probable that the abdomen of mites is more than the abdomen of other Arachnids. If one examines a Solpuga, he sees that the cephalothorax is divided into several portions, and it may be that the cephalothorax of mites represents only the anterior of these, while the abdomen of mites represents the abdomen of Solpuga plus the two posterior divisions of the cephalothorax. In Tarsonemus, and some other genera, the abdomen shows on the dorsum distinct traces of segmentation. On the venter there is still less distinction between parts, and in several groups, as Ixodidæ and some Gamasidæ, the genital segment is pushed forward between the legs so far that the genital aperture is close to the mouth. In other forms the genital opening is at the extreme tip of the body, and the anus is upon the dorsum. 
The cephalothorax, or anterior part of the body, commonly has one or more pairs of simple ocelli-like eyes. They are usually sessile, but sometimes elevated on pedicels.

The mouth-segments form typically a truncate cone or beak. Sometimes it is partially or completely retracted into the body. The mouth parts are the mandibles and palpi. Frequently there are other parts, as a hypopharynx, a lip, or definitely separated maxillæ, as will be mentioned under each family. Several investigators have claimed that there are three or four mouth appendages, and there are structures in some forms that indicate three. The mandibles generally are of two joints. The last is often opposable to a projection of the preceding, so as to become chelate. However, in many forms the mandibles are slender, needle-like, and suited for piercing. In each of the three large families (Oribatidæ, Gamasidæ, and Tyroglyphidæ) which typically have chelate mandibles there is one genus with styliform piercing mandibles. The palpi have never more than five joints; the last is frequently provided with peculiar sensory hairs. In some cases the palpi have a geniculate attitude. The various forms of palpi may be grouped into four classes. (1) Where they are simple, filiform, and have a tactile function; (2) where they are modified for predatory purposes, being provided with spines, hooks, or claws; (3) where the last joint is opposable to the preceding, so that the mite may by its palpi cling to some object; (4) where they have become obsolete, and are more or less united to the rostrum. The basal joints of the palpi are at times differentiated to form maxillæ.

In several families there is a distinct lingula, tongue, or hypostome, which arises from the inner base of the beak, and may be divided or simple. It may have a groove above, called the vomer. The hypostome is usually not visible except by dissection, but in the ticks it is very large and roughened with sharp teeth.

Sometimes the basal joints of the palpi unite to form a lip, or labium. Above the mandibles in many forms is a thin corneous plate, known as the epistoma. Its sides may be partly united to the beak or lip below and thus form a tube, called the oral tube, for it is through it that the mandibles are protruded.

The pharynx, or sucking portion of the alimentary tract, is sometimes prolonged forward into a sort of cone between the mouth-parts.

The opening of the body into which the mouth-parts are inserted is known as the camerostome. In one group (Uropoda) the anterior legs are also inserted into this camerostome.

The adult mite generally has four pairs of legs, and the larva three pairs. It has been shown that the embryo of certain forms (Gamasus and Ixodes) has four pairs of legs before birth, but one pair is aborted to be again developed at the nymphal stage. This is an indication that the six-legged larva is a secondary development, and lessens the 
apparent difference between Acarina and other Arachnida. The legs are composed of from five to seven segments; in some forms the apical joints are subdivided, but do not form genuine segments. The length and character of the joints vary in the different families, but usually there are distinguishable the following parts: coxa, trochanter, femur, patella, tibia, and tarsus. In some cases the femora are divided into two parts. The legs are provided with hairs and spines, sometimes modified for some particular function. In several groups there are organs on the anterior legs which appear to have an auditory function. The last joint or tarsus is commonly terminated by from one to three claws or ungues. In some groups there is a difference in this respect between the young and the adult. The claws are not often toothed. In many cases there is a median cup-shaped sucker,

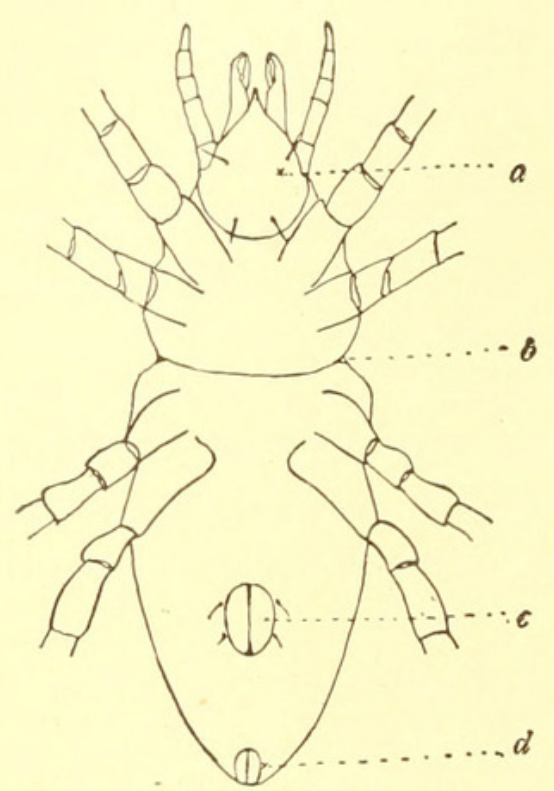

Fig. 2.-VENTRAL VIEW OF A Mite. $a$, BEAK; $b$, TRANSVERSE FURROW; $c$, GENITAL, APERTURE; $d$, ANAL APERTURE. pulvillus, caroncle, or ambulacrum between the claws or bearing them.

The reproductive organs, as in other Arachnids, open on the ventral surface of the abdomen near the base. The female aperture (vulva or epigynum) is of various shapes, and sometimes closed by flaps or folding-doors. The male aperture (epiandrum) is usually smaller than that of the female. The body is often provided with hairs, bristles, or scales, which are of characteristic nature and arrangement in each species.

In many of the soft-bodied forms there are chitinous plates, scutæ, or shields, sometimes so large or so numerous as to almost completely cover the mite. These shields are often sculptured or pitted in a characteristic manner. Frequently there are secondary sexual differences both of color and structure, as will be noticed under each family. The male is often a little smaller than the female, but in many cases there is no apparent difference in size.

The internal anatomy of mites is marked by great centralization of parts, the various organs being much more crowded together than with other Arachnids. The alimentary canal, when fully developed, consists of the pharynx or sucking-organ; the cesophagus; the stomach or ventriculus, with its cœeca; the hind gut or intestine, and the Malpighian vessels which enter the latter near the rectum.

The pharynx is a partially chitinous tube, convex below, concave above; to its upper, art or roof are attached the muscles, which, upon contracting, elevate the roof. A series of muscles, each moving just after the one in front, produces a steady flow of food to the stomach. 
The cosophagus is a long simple tube; the stomach is of varied size and shape, according to the food-habits. Sometimes there is an enlargement of the esophagus near its end, thus forming an ingluvies or crop. In some forms the cœea are extremely long or numerous. The Malpighian vessels, when present, are two in number, and enter the short intestine near its end. The latter is sometimes provided with an enlargement, the colon. In many mites the digestive system is much simplified. In many, if not all, of the forms allied to Trombidium, and the water-mites, there is no certain connection between the stomach or ventriculus and the anus. The ventriculus ends blindly; the anus opens into a large tube, supposed to have an excretory function. Many of these forms feed on animal juices, so probably have no excreta.

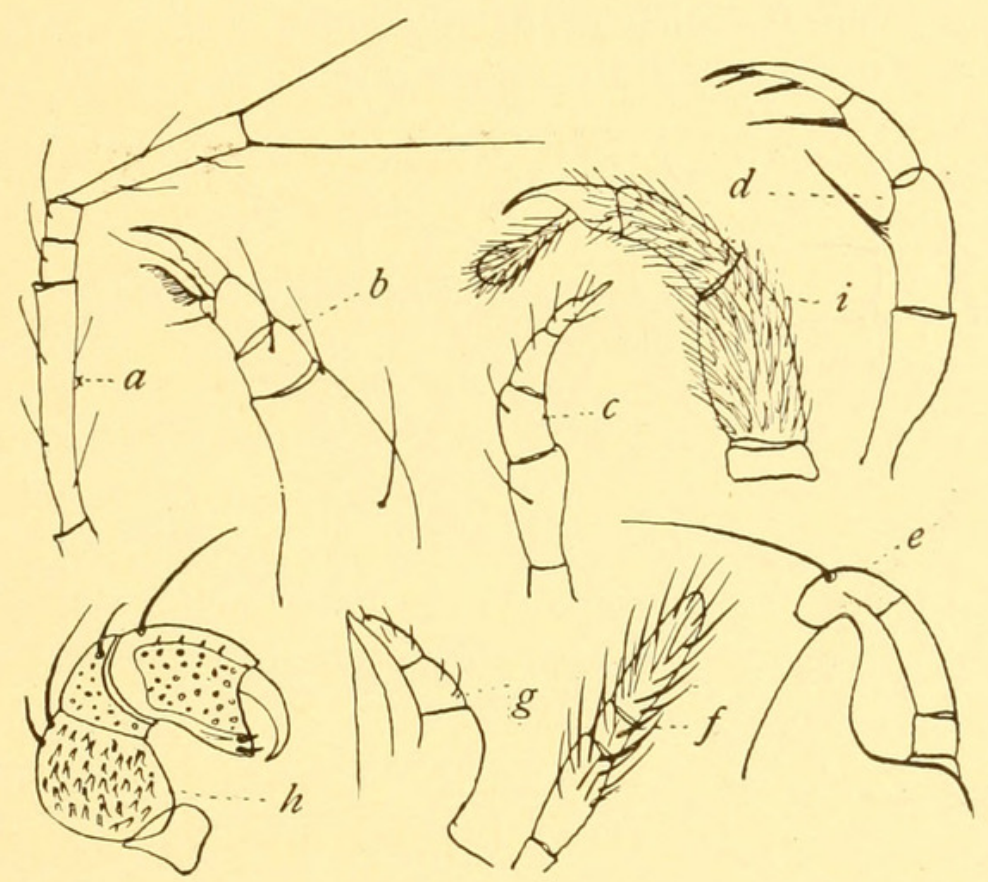

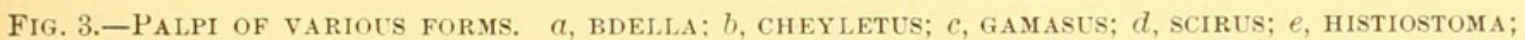
$f$, EUPODES; $g$, SARCOPTES; $h$, ARRENURUS; $i$, TROMBIDIUM.

The nerve ganglia are united into one mass of considerable size, pierced by a hole for the œsophagus. This brain cloubtless is formed of the supra and sub-cesophageal ganglia and their commissures, but so closely are the parts united that all trace of demarcation is commonly lost. The principal nerves arise from this brain. There is one unpaired nerve, and nine or more pairs of nerves. Three sets of paired nerves and the unpaired one arise from the supra-œsophageal ganglion and are of small size. The other six or more sets of paired nerves arise from the sub-œsophageal ganglion and are mostly of larger size. The unpaired, or medium nerve, goes to the pharynx. The paired nerves of the supra-œsophageal gang'ion go to the eyes, the mandibles, and the large vertical muscles neg the base of the rostrum. Of the nerves of the sub-œsophageal ganglion, one pair goes to the palpi, four to the legs, and one to the genital and other abdomi- 
nal organs. Sometimes there are other nerves that extend to the posterior part of the body.

The reproductive system is often highly developed, and frequently occupies a considerable part of the body. The male testes are large, lobate, and open into two tubes, the vasa deferentia, which, uniting, form the ductus ejaculatorins, which may open through a penis. The testes are often united. The ovaries of the female (sometimes united) are situate in the middle part of the body, of varying shape, and open into two tubes - the oviducts - which unite to form the vulva. The latter may have a spermatheca attached, and may open through an extensible ovipositor. In some families the vulva is not a bursa copulatrix, but there is a special copulatory opening near the anus. In other forms the female organs are very different, as will be mentioned under the families.

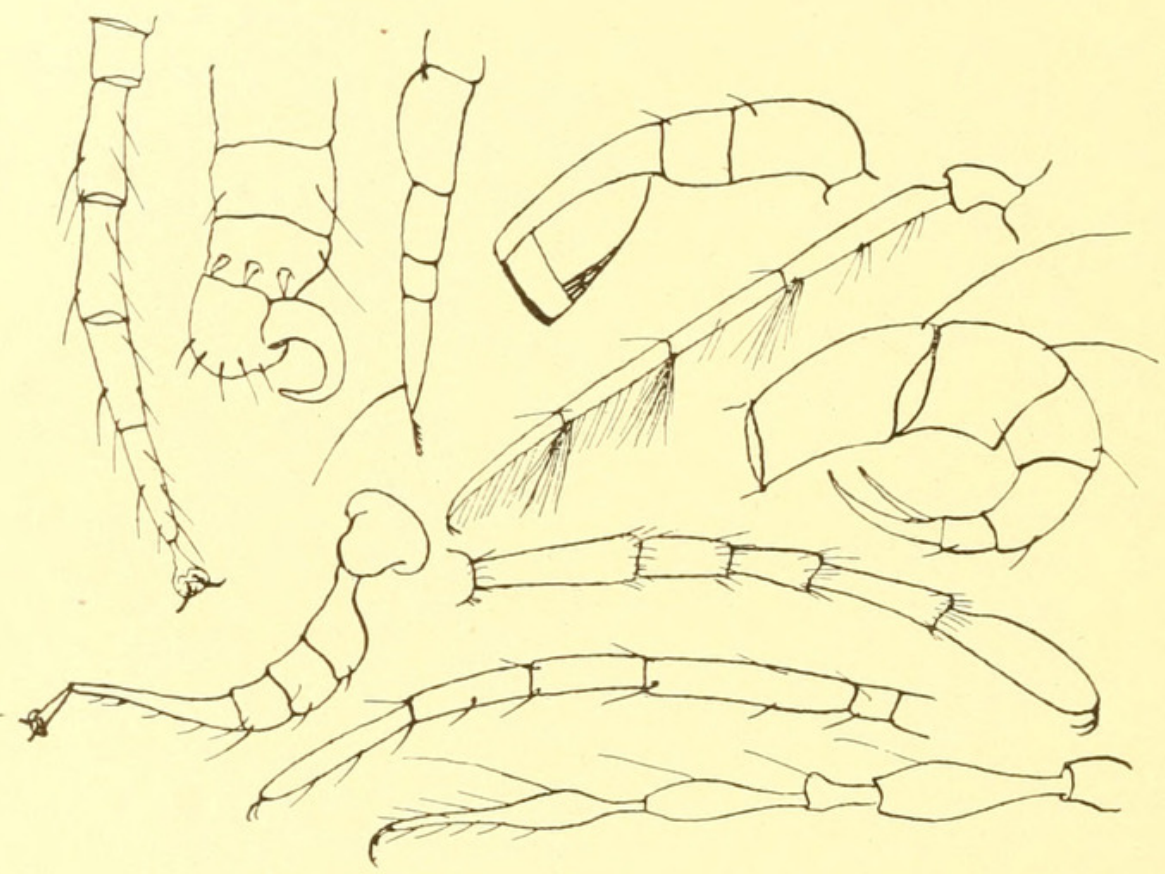

Fig. 4.-Legs of VARIOUS mites.

In the Gamasidæ, Tyroglyphidæ, and Oribatidæ there are a pair of glands in each side of the abdomen, each opening by a pore in the skin. They contain a yellowish, oily liquid, and are considered excretory glands; Michael has called them expulsory vesicles. In most mites there are several glands in the head region, some of them evidently of a salivary nature, but others are often present whose function is unknown. Some of them open into the mouth, or pharynx, and others may open at the base of the mandibles.

In some mites there is a well-developed dorsal pulsating organ or heart, but in most mites it is not present. In these latter there is an irregular motion of the body-fluids kept up by the action of the muscles in other movements. Many mites have an elaborate tracheal system for breathing. These tracheæ open in various parts of the 
body; in many common forms they open near the mandibles. In ticks and Gamasids they open near the hind legs. In other forms they open in the acetabula or coxal cavities. The openings of the tracheæ are through stigmata or spiracles which vary in different forms. Commonly there are one or two main tracheal trunks in each side of the body, each giving off many branches. In some forms there is a short tracheal trunk which at its tip gives rise to a great number of fine long tracheæ, each of which is unbranched. A great many mites, however, have no internal respiratory system whatever. In these forms the skin is soft, and they absorb oxygen by osmosis through the general surface of the body.

The muscular system of mites varies greatly in the different genera. Strong muscles are attached to the mandibles for extending and moving these organs. Still more powerful ones are attached to the legs, and those for the pharynx and organs of generation are often promi-

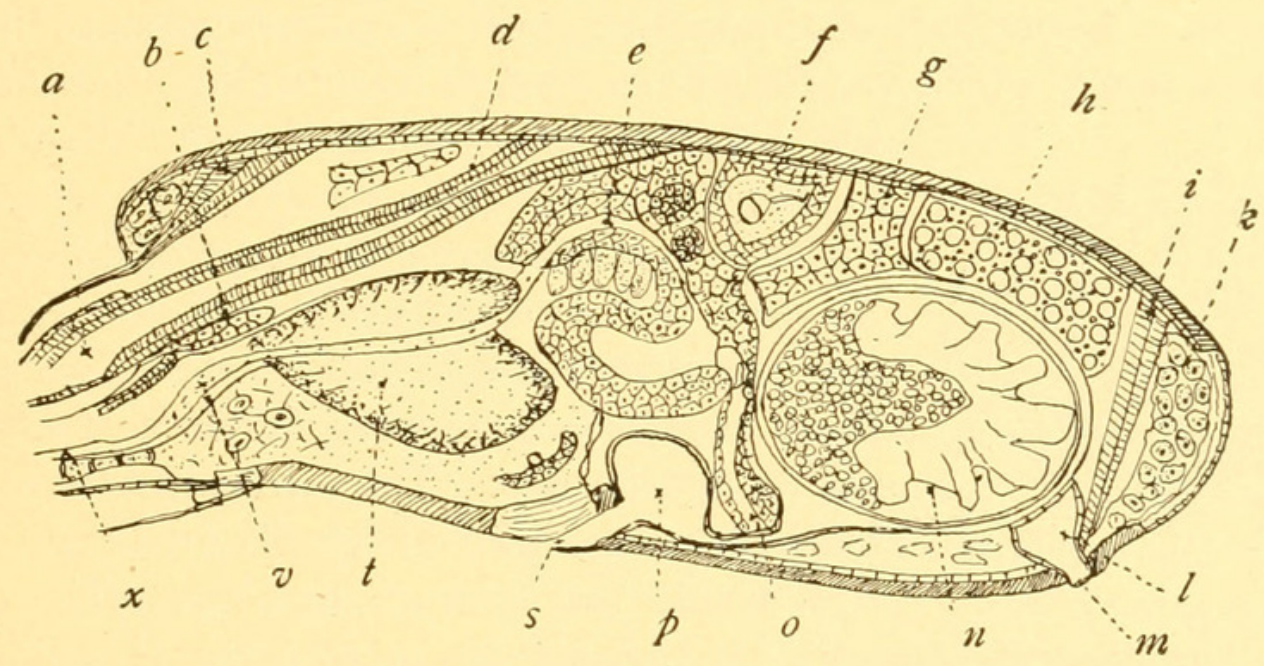

Fig. 5.-ANatomy of Gamasus. $a$, mandible; $b$, Salivary gland; $c$, Retractor rostrum; $d$, mus-

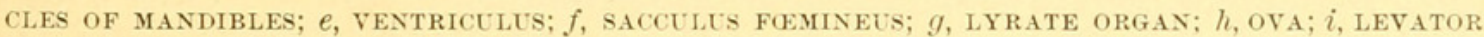
ANi; $k$, FAT CELLS; $l$, CLOACA; $m$, ANUS; $n$, EMBRYo; 0 , HIND GUT; $p$, VAGINA; $s$, VUlVA; $t$, BRAIN; $v$, ESOPHAGUS; $x$, PHARYNX.

nent. There are also muscles connecting various parts of the integument and in some cases one or two pairs attached near the middle of the dorsum. These latter often produce the depressions in the dorsal surface which are commonly found in many of the soft-bodied mites.

The life histories of mites are extremely variable, and will be described under each family. There are typically four stages-egg, larva, nymph, and adult. Many mites, however, have developed a complicated arrangement of forms that almost obscures this fundamental simplicity. Most of these additional phases occur during the nymphal stage, the growing stage of the acarian.

Nearly all mites deposit eggs, but there are a few forms known to be viviparous, or at least ovoviviparous, and one, Pediculoides, brings forth adult males and females.

The general plan of development is as follows: The egg is usually 
deposited by the female. Often within this egg, while the embryo is developing, an inner membrane is formed which incloses the young mite; this stage is the "deutovum." The outer shell may be cracked so as to show this membrane, or it may be wholly discarded. The larva at birth has but six legs. It feeds for awhile, then passes into a resting stage which in time discloses the eight-legged nymph. The added pair of legs is the fourth, at least usually. During the nymphal period the mite may molt one or more times and change its appearance, but is always destitute of true genital orifices. At the end of the nymphal stage it passes again into a quiescent condition, and in due time molts into the adult mite. During these resting stages much of the internal anatomy of the mite may undergo histolysis, each new stage being rebuilt from the disintegrated tissues of the preceding stage. The genital organs are, however, not affected by these histolytic processes.

The common impression that most mites are parasitic is entirely erroneous. About half of the known species are not parasitic in any stage, and many which are found attached to insects and other animals

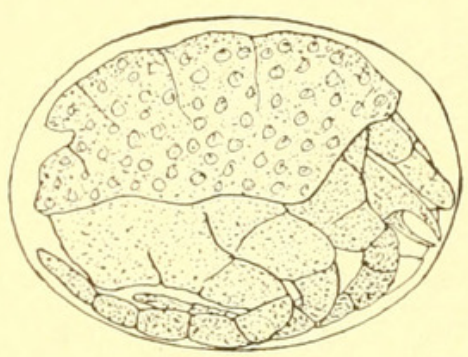

Fig. 6.-EMbryo of Gamasus. are not true parasites thereon. Most mites ordinarily move quite slowly, but when disturbed some can travel at an astonishing pace. A very few species are fitted for leaping. Aquatic mites occur in both fresh and sea water. Ticks occur on mammals, birds, and even on snakes and turtles. The bird-mites live on the feathers and skin of birds; the itch-mites burrow within the skin of man and other mammals. Other species live in the cellular tissue of birds; a few occur in the tracheal passages of seals, and one has been found living within the lungs of a monkey. Many species feed on living plants, and the gall-mites produce curious deformations on leaves and twigs.

Mites are distributed throughout the globe, but appear to be most numerous in temperate regions. Many are abundant in high latitudes. Single species are sometimes widely distributed; however, as a whole, mites are subject to the usual rules of geographic limitation. Most of the parasitic forms follow the distribution of the host. A few of the free mites are common in widely separated regions, but many, especially the myrmecophilous ones, are very local. Most of the free-living species and those parasitic on plants spread by their own wanderings, but many have developed, for the purpose of migration,

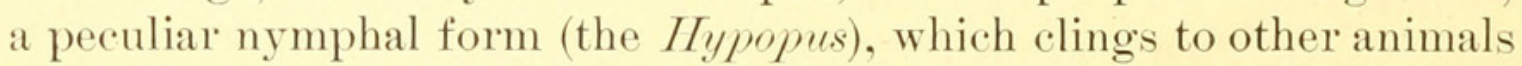
that will visit places similar to the mite's birthplace. Most mites are not readily destroyed by cold or moisture, and through this hardiness can extend their distribution.

Most mites have but few enemies outside of their predatory relatives. 
There are, however, various cases of protective resemblance, especially among the immature forms. No examples of mimicry, I think, are known.

A great many mites are more or less injurious to the property of man. Three, at least, can be ranked as pests of great importance, namely, the cattle-tick, the sheep-scab, and the pear-leaf blister-mite. The classification of mites has in recent years been developed to a considerable degree. The group is usually held to be an order, including about thirty natural groups. An excellent historical review of the classification of Acarians has been presented by Trouessart. ${ }^{a}$ The value of these natural groups of mites has been variously estimated by different authors as tribes, subfamilies, and families. Kramer in 1877 originated an ingenious scheme, which has been extended by Canestrini, whereby the mites are arranged according to the position of the opening of the tracheal system. By this method there are six main divisions of the Acarina.

Canestrini's classification is as follows:

Astigmata - Vermiformia and Sarcoptina.

Hydracarina - Water mites.

Prostigmata - The Trombidoidea and Eupodoidea of this paper.

Cry ptostigmata-The Oribatid mites.

Metastigmata - The ticks.

Mesostigmata - The Gamasoidea of this paper.

Trouessart has modified this scheme somewhat. He divides the mites into two orders, Acarina and Vermiformia; the latter group again into Octopoda (Demodicidæ) and Tetrapoda (Eriophyidæ). The true Acarina he divides into three suborders, the Prostigmata (including the Hydracarina of Canestrini), the Metastigmata (including the Mesostigmata and Cryptostigmata of (anestrini), and the Astigmata (including only the Sarcoptina). In the writer's opinion the Oribatide and Tyroglyphidæ are more closely related than indicated in either of these classifications.

In the arrangement used below, the main divisions are about the same, although based largely on other characters. These characters will be found defined under the various families; and although there are exceptions to the tables they are not prominent, and to have provided for them would heavily incumber the synopses. The characters used in defining genera and higher groups vary greatly according to the group. In some cases genera are based on very minute structures, which in other families are of no value. In several groups the habitat is the best clew to the systematic position. About three hundred and fifty species are known from this country, where there are doubtless a thousand or more, so that the student must not be surprised to

\footnotetext{
a Revue des Sciences naturelles de l'Ouest, 1891, pp. 289-308; 1892, pp. 21-56.
} 
find forms that do not fit into tables. Several of the families are not natural, and future study will greatly modify existing systems.

I have not made many new genera in the American mites. I believe in keeping genera as broad as possible. Division of a genus should be made only on grounds of convenience or those of zoological necessity. Because a group of species in a genus differs from the other forms by some structural character, there is not, I think, sufficient reason for a new genus. But whenever a species or group of species differs from the others by several disassociated points of structure, together with differences in life history or habits, then a new genus is advisable. However, in using an adopted classification it is sometimes not easy to place a new form without either making a new genus or modifying the characters of existing genera. The history of Acarology warrants the student in using much caution in the creation of new genera or higher groups.

In regard to nomenclature, I have not departed, save in a few cases, from that in common acceptance among acarologists. In some families there has been much difference of opinion, and lately Doctor Oudemans, an able Dutch acarologist, has revised the nomenclature. It is difficult to escape some of these changes, but others I can not accept, nor go back of 1758 for generic names. The larger groups I have called superfamilies, in accordance with the custom of the best zoologists, and these divisions are practically the same as I used in 1895 .

To the ordinary person mites do not exist. Occasionally he may have painful evidence of their presence, but he has no idea of the number of specimens and species around him. Yet a little careful searching will reveal a world of these tiny creatures. Although Müller early described many water-mites and Hermann (1804) and von Heyden (1816) had gathered a few, yet this world of mites was practically unknown until discovered by C. L. Koch about 1840 . Since then a number of naturalists have partially explored its shores, and sometimes penetrated into the interior. Now there are about a dozen persons who seriously study acarology and nearly as many more who devote themselves to the water-mites.

SYNOPSIS OF SUPERFAMILIES.

1. Abdomen annulate, prolonged behind; very minute forms; often with but four legs . . . . . . . . . . . . . . . . . . . . . . . . . . . . DEMODICOIDEA

Abdomen not annulate nor prolonged behind; always with eight legs . . . . . . . . 2 2. With a distinct spiracle upon a stigmal plate on each side of body (usually below) above the third or fourth coxæ or a little behind; palpi free; skin often coriaceous or leathery; tarsi often with a sucker ........................ 3

No such distinet spiracle in a stigmal plate on this part of body . . . . . . . . . . . 4

3. Hypostome large, furnished below with many recurved teeth; venter with furrows; skin leathery; large forms, usually parasitic.

Hypostone small, without teeth; venter without furrows; body often with coriaceous shields, posterior margin never crenulate; no eyes ..... GAMASOIDEA 
4. Body usually coriaceous, with few hairs; with a specialized seta arising from a pore near each posterior corner of the cephalothorax; no eyes; mouth-parts and palpi very small; ventral openings of abdomen large; never parasitic; tarsi never with a sucker ..........................................

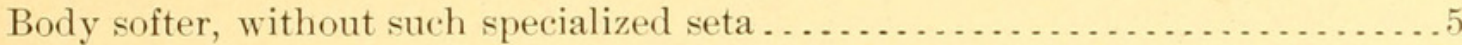

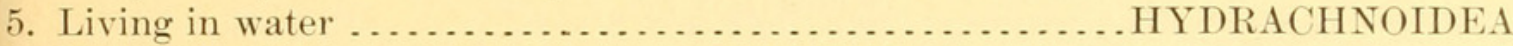

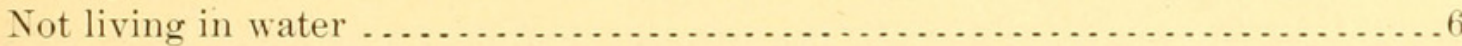

6. Palpi small, three-jointed, adhering for some distance to the lip; ventral suckers at genital opening or near anal opening usually present; no eyes; tarsi often end in suckers; beneath the skin on the venter are seen rod-like epimera that support the legs; body often entire; adult frequently parasitic.

SARCOPTOIDEA

Palpi usually of four or five joints, free; rarely with ventral suckers near genital or anal openings; eyes often present; tarsi never end in suckers; body usually divided into cephalothorax and abdomen; rod-like epimera rarely visible;

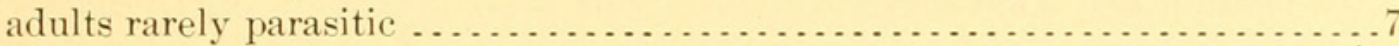

7. Last joint of palpi never forms a "thumb" to the preceding joint; palpi simple, or rarely formed to hold prey; body with but few hairs...... EUPODOIDEA

Last joint of palpi forms a thumb to the preceding, which ends in a claw (a few exceptions); body often with many hairs.............. TROMBIDOIDEA

\section{SYNOPSIS OF FAMILIES.}

\section{DEMODICOIDEA.}

With but four legs, of five joints each; living on plants, often in galls. . EriopH yid F With eight legs, of three joints each; living in skin of mammals. ... Demodicide

\section{SARCOPTOIDEA.}

1. With trachex; no ventral suckers; legs ending in claws; body divided into cephalothorax and abdomen; the female with a clavate hair between legs I and IInot parasitic on birds or mammals ...................... TARSONEMIDE

Without tracheæ; no such clavate hair . . . . . . . . . . . . . . . . . . . . 2

2. Genital suckers usually present; not parasitic on birds or mammals; skin usually without fine parallel lines. . . . . . . . . . . . . . . . . . . . . . . . . . . . 3

Genital suckers absent; parasitic on birds or mammals; skin with fine parallel

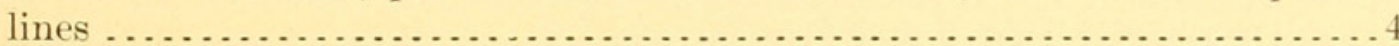

3. Legs short, without clavate hair on tarsi I and II; living on insects.. CANESTRINIDE Legs longer, with clavate hair on tarsi I and II; not parasitic (except on bees)

TYROGLYPHIDE

4. Possessing some specially developed apparatus for clinging to hairs of mammals

LISTROPHORIDA

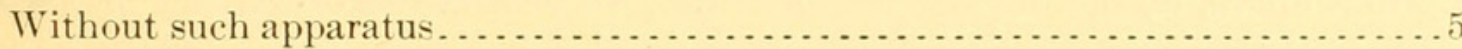

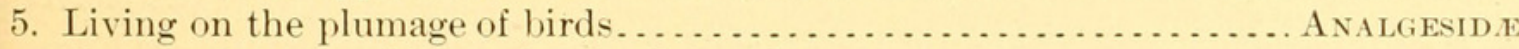

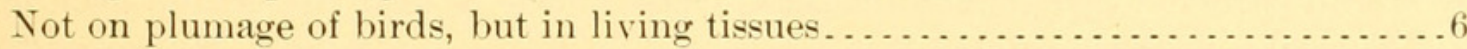

6. Vulva longitudinal; in skin and cellular tissue of birds........... CүтоLeichid

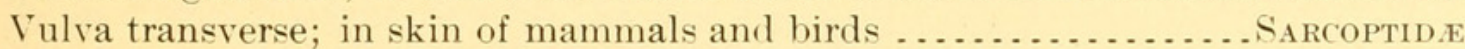

\section{GAMASOIDEA.}

1. Parasitic on vertebrates; mandibles fitted for piercing; body sometimes constricted

DERMANYSSIDF

Free, or attached to insects, rarely on vertebrates, never on birds . . . . . . . . . 2

2. First pair of legs inserted within the same body-opening as the oral tube; genital apertures surrounded by the sternum .................. UROPODID

First pair of legs inserted at one side of the mouth-opening; male genital aperture usually on the anterior margin of sternal plate.................. GAMASIDE 


\section{ORIBATOIDEA.}

Cephalothorax movably attached to the abdomen; palpi four-jointed.. HopLODERMid E Cephalothorax not movable; palpi five-jointed .................... Oribatide

\section{IXODOIDEA.}

No scutum; no ventral shield; mouth-parts of adult not prominent from above; no pulvillus to tarsus in adults . . . . . . . . . . . . . . . . . . ARGASID.E

Scutum present; sometimes ventral shields; mouth-parts of adult prominent from above; pulvillus to tarsus of adults ....................... IxoDIDE

\section{EUPODOIDEA.}

Palpi often geniculate, or else fitted for grasping prey; mandibles large and snout-like; cephalothorax with four long bristles above, two in front, two behind; last joint of leg I longer than preceding joint, often twice as long

BDELLide

Palpi never geniculate, nor fitted for grasping prey; beak small; cephalothorax with bristles in different arrangement; last joint of leg I shorter or but little longer than preceding joint; eyes when present near posterior border. EuPODID E

\section{TROMBIDOIDEA.}

1. Legs I and II with processes bearing spines; skin with several shields; coxæ contiguous . . . . . . . . . . . . . . . . . . . . . . . . . . . . . . .

Legs I and II without such processes; few if any shields . . . . . . . . . . . . 2

2. Palpi much thickened on base, moving laterally, last joint often with two pectinate bristles; no eyes; leg I ending in several long hairs, adult sometimes

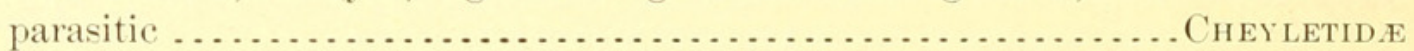

Palpi less thickened, moving vertically; eyes usually present; leg I not ending in

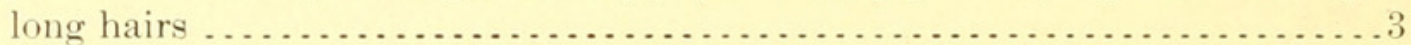

3. Coxæ contiguous, radiate; legs slender, bristly; body with few hairs; no dorsal

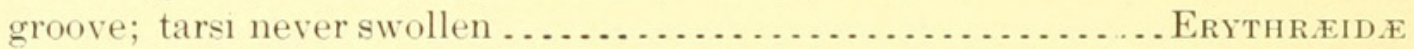

Coxæ more or less in two groups, legs less bristly . . . . . . . . . . . . . . . . . . 4

4. Body with fewer, longer hairs; often spinning threads; no dorsal groove; tarsi never swollen; mandibles styliform (for piercing).......... TETRANYchID.E

Body with many fine hairs or short spines; not spinning threads; often with dorsal groove; tarsi often swollen ................................ 5

5. Mandibles chelate (for biting) . . . . . . . . . . . . . . . . . . . . . .

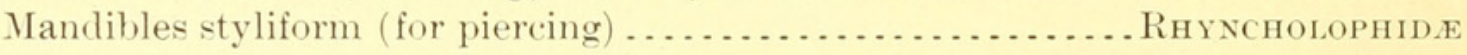

\section{HYDRACHNOIDEA.}

Mouth-parts carried upon a distinct beak; no ventral suckers; living in the sea HALACARIDE

Nouth-parts not carried upon a beak; usually suckers near the genital openings; usually in fresh water. HYDRACHNIDE

\section{Family EUPODID E.}

The Eupodidæ is a small family of small mites, several species of which are among our most common acarians. They are soft-bodied, delicate mites, with moderately long to very long legs. The body shows more or less distinctly the division into cephalothorax and abdomen; the former usually bears an eye each side; the latter carries 
a few simple hairs. The palpi are short and simple, four-jointed, and with only a few hairs. The mandibles are rather small, but distinctly chelate; in one genus they are very large. The legs are six or seven jointed and terminate in two simple claws, and often with a median plumose pulvillus. The venter has the usual openings, but in Notophallus the anal aperture is on the dorsum of the abdomen. These mites can run rapidly, and Eupodes can make considerable leaps. Most inhabit the ground, but some are found on the leaves of trees. All are predaceous and feed on various small insects or insect eggs. They seem to delight in cold, damp places, and can be found in winter still active among and under fallen leaves. They are among the most common acarians in high latitudes, and are also frequent in caves, both of this country and of Europe, where their simple and primitive structure is well suited to the conditions. Their internal anatomy has lately been investigated by Nordenskiöld, who finds that Rhagidia is among the most primitive of the Trombidoidea. The esophagus, which opens near the tip of labium or underlip, is very slender, and after passing through the large "brain," enters a very large stomach. From the upper part of this arises the intestine, which soon expands into a very large colon, opening at the tip of body. The eggs, as far as known, are laid upon the surface frequented by the adult. The larræ resemble the parent, while the nymph differs only in size. There is no sexual dimorphism. Most of the common species vary a great deal

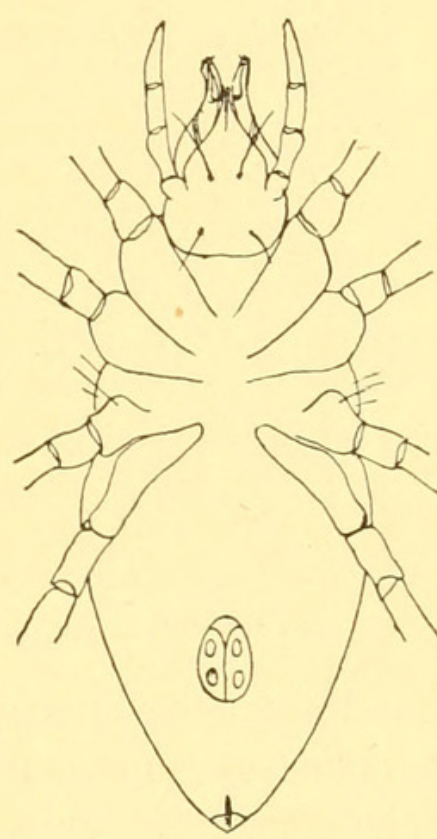

Fig. 7.-VENTER OF AN EUPODID. in markings, the consequence being that Koch described each of the common European species under many different names, several having from ten to twenty synonyms. Our forms have been collected only in the northeastern States.

Five of the described genera occur in the United States; these may be tabulated as below:

1. Legs extremely slender, anterior pair much more than twice as long as body Linopodes

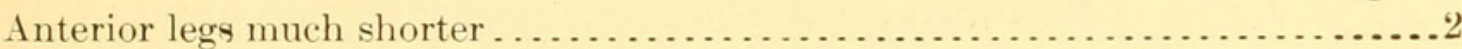

2. Hind femora much thickened; anterior legs much longer than others ... Eupodes

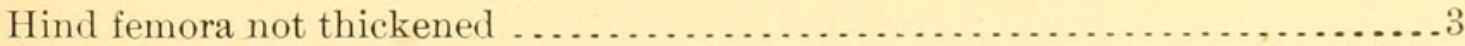

3. Anal opening on the dorsum; mandibles small . . . . . . . . . . . . Notophallus Anal opening on venter . . . . . . . . . . . . . . . . . . . . . . . . .

4. Mandibles very large; legs longer than body . . . . . . . . . . . . . . Rhagidia Mandibles small; legs scarcely as long as body Tydeus

Our one species of Linopodes is a very pretty pale yellowish or reddish mite, with some white marks, one on the back is in the form 
of a T. It is common on the ground under pieces of wood, bark, etc., that have lain there sometime. The first pair of legs is used as

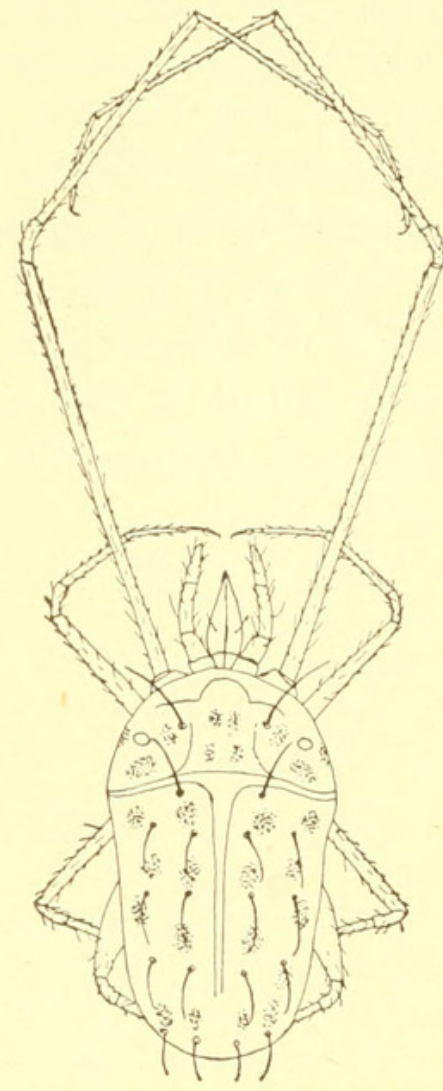

Fig. 8,-LINOPODES ANTENNEPES. feelers. Usually the mites walk slowly, but when disturbed run very rapidly. We have several species of Eupodes, all more or less marked with red. The common one, E. variabilis Banks, is found in the same places as Linopodes. Another species occurs on the seashore between tide-marks.

The species of Notophallus are blackish, with a red spot above, and red legs. They occur in damp fields, under stones, or in moss. But one species of Tydeus is known from the United States, T. gloveri Ashmead. It occurs on orange leaves in Florida, and feeds on the young and eggs of scale insects ( $M y$ tilaspis spp.). It is pale reddish or yellowish in color and has a subpyriform body, with rather short legs. Moniez has described a species of Tydeus (T. molestus) as attacking man, much on the "red-bug" style. Rhagidia is a remarkable genus. The

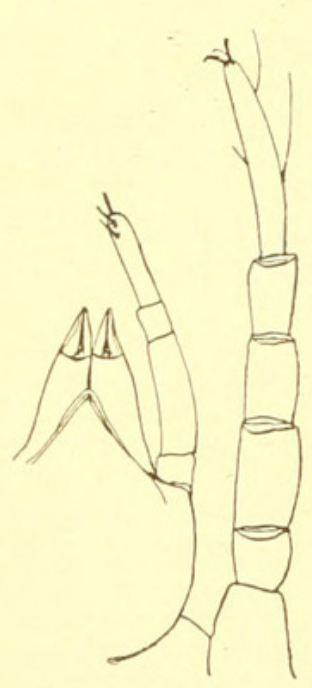

FIG. 10.-TYDEUS, BEAK AND LEG I FROM BELOW. species are pale or whitish in color, and occur under damp, fallen leaves and on moist soil. It is much larger than the other species of this family, and sometimes fully one millimeter long:

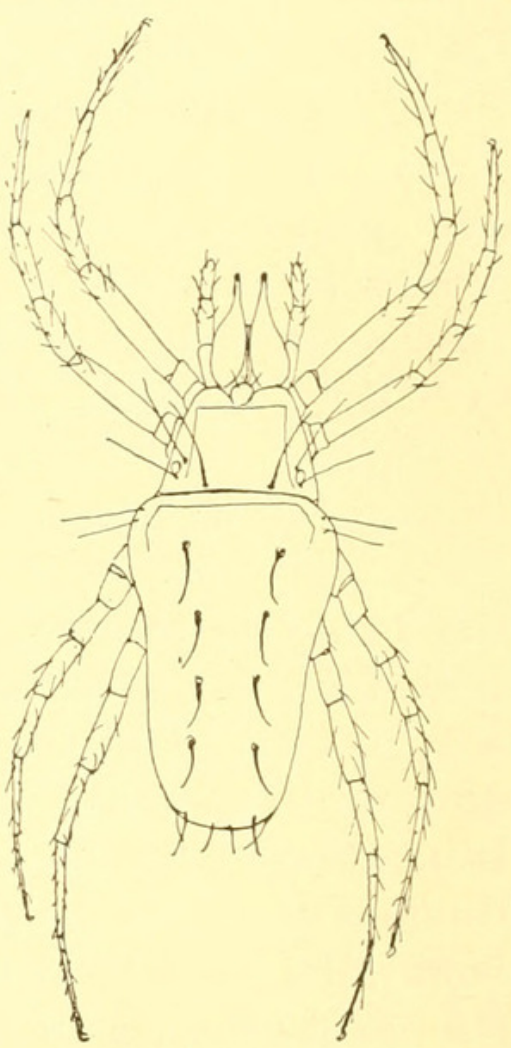

Fig. 9.-RHAGIDIA PALLIDA. Its structure is in many ways very similar to that of certain Solpugida and suggested to Thorell its generic name, which is a diminutive of Rhax, a genus of Solpugida. It is probable that it is the most primitive of all existing mites, and points to the close relationship of the Acarina to the Solpugida. Our common species, $R$. pallida Banks, is found throughout the country, but more commonly in the north. Other species are found in Europe, Japan, Kerguelen, Chile, and the arctic regions.

A European mite of this family, Erynetes limaceum Koch, some- 
times occurs upon certain species of slugs (Limax), and sometimes attached to a fly (Sarcophaga). In this country a mite (Iypopus concolor Haldeman) has been recorded by Binney as found upon a snail. It may belong to this genus, Erynetes. Penthaleus embraces several species, having a black body, with a red spot behind, and red legs. Here we may also refer to the genus Alycus, which is placed in a separate family. It looks much like a minute Trombidium, but has simple palpi. Two forms are known in Europe.

\section{Family BDELLID E.}

The members of this family are known as "snout mites," from the appearance of the beak or rostrum. The body shows distinctly

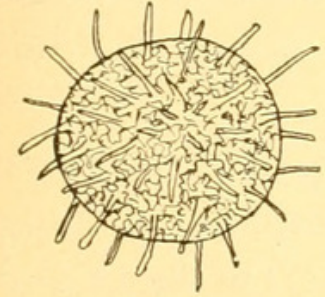

FIG. 12.-EGG OF BDELLA. the division into cephalothorax and abdomen, the two

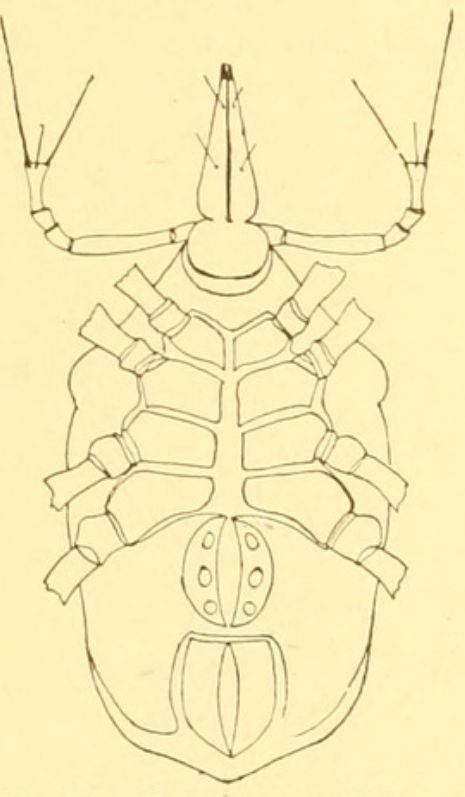

Fig. 11.-Venter of a BDEli. hind pairs of legs apparently arising from the latter. The cephalothorax is subtriangular, with a few long bristles above and usually one or two eyes on each side, commonly near the pos. terior corner. The mandibles are large, slender, tapering, more or less united along the median line, and together form a prominent cone in front. They are chelate in the typical genus, but in some of the other genera end in one claw. The palpi arise apparently from near the base of the mandibles, but really from a part of the body below them. They are either three or five jointed, the second joint being the longest. In some forms they are provided with spine-like bristles, but usually with fine hairs, the terminal oncs often of great length. The antennæ are frequently elbowed between the second and third joints. The abdomen is usually broadest at the shoulders and tapering, but rounded behind; it bears only a few hairs or bristles.

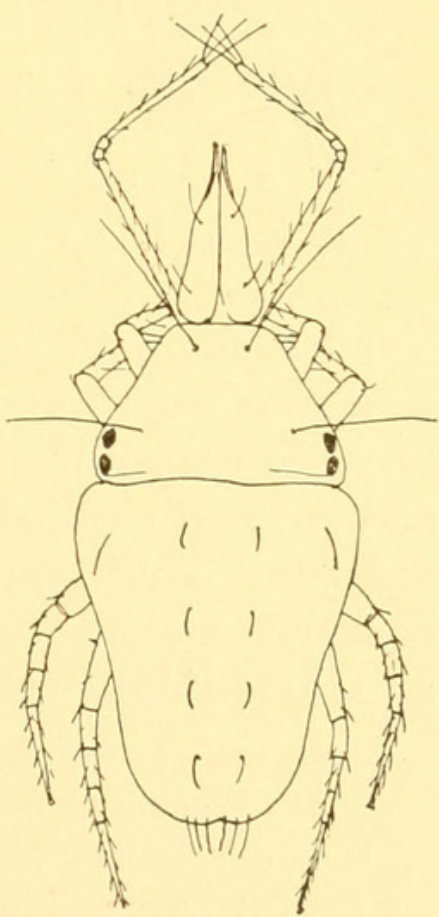

FIG, 13.-BDELIA PEREGRINA. The venter has the usual two apertures near the posterior part, the genital usually the larger. The legs are quite long and slender, with a few scattered small hairs. They terminate in two claws with a median hairy brush beneath. The hind coxæ are well separated from the anterior pairs. 
The internal anatomy has been studied by both Karpelles and Michael. It is peculiar in several respects. There is a large sac or diverticulum connected to the cesophagus above. Michael has termed it the receptaculum cibi, and believes its purpose is to store the food for a short time. The ventriculus ends blindly; there being no com-

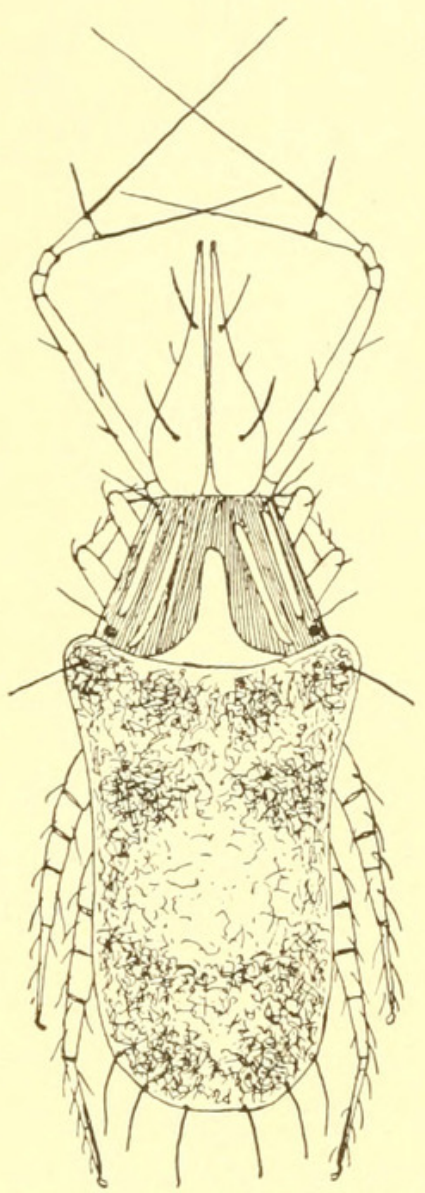

Fig. 11.-BDELLA TENEI.I.A. munication to the anus. There are three pairs of glands in the anterior part of the body, besides one large median gland. One pair opens at the base of the mandibles and their function is unknown. Two pairs open into a common duct which leads to the mouth; they are probably salivary glands. The supra and sub-cesophageal ganglia are more distinctly separated than in other mites that have been examined. The pharyngeal nerve (which in other mites is single) in Bdella is split in two parts. The male organs are remarkable for possessing two single and one pair of accessory glands, whose function is little understood. In the female there is but one oviduct.

Mr. Trägårdh has figured the egg of B. arctica; it is nearly spherical, and with a number of long spines scattered over the surface. The larva and nymph have much resemblance to the adult. They are never parasitic, and there is no sexual dimorphism.

The species are usually red in color, but some are blackish. They are predaceous in habit and wander about in search of food-any small creature they can find. The palpi serve as tactile organs in most genera, but in Scirus they are used to capture and hold the prey. These mites can run quite fast, and move backward as well as forward. Several species are known from the Arctic regions. Four genera have been recognized in this country, and one more (Scirula) is known in Europe. They may be separated by the following table:

1. Mandibles chelate; two eyes each side; palpi geniculate, and ending bluntly with two or more long bristles . . . . . . . . . . . . . . . . . . . . . . . . . . 2

Mandibles ending in one claw; no eyes, or only one each side; palpi not geniculate, and ending in a claw

2. No median eye on front margin of cephalothorax; tip of tarsus with one or two plumose hairs each side.

Bdella

A median eye on front of cephalothorax; tip of tarsus without plumose bristles.

Cyta

3. Palpi of three joints, and without spine-like bristles, one eye each side on ceph-

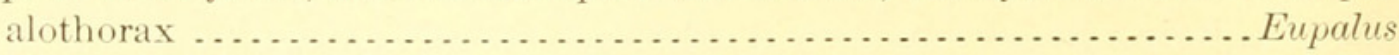

Palpi of five joints; and with spine-like bristles; no eyes.............. Scirus 
Trouessart has separated the group of Scims from the Bdellidx and placed them as a family of the Trombidoidea; this does not appear natural to me. Of Scirus but one species has been described in the United States; it lives in damp places, and is very active. Of Bdella we have a number of species, and some are common. They usually inhabit moist places, moss, rotten bark, etc. One species (B. marina Packard) is common along the north Atlantic shore between tidemarks. B. cardinalis and B. peregrina are common on damp soil; B. tenella, under rotten bark. Michael has recorded finding a species of Bdella abundantly on the web of a tube-weaving spider, Amaurobius ferox.

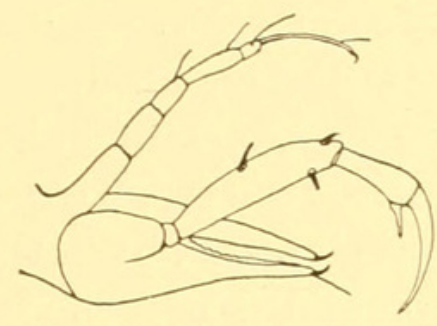

FIG. 15.-MANDIBLES AND PALPUS OF SCIRUS.

The mites were not disturbed by the spider and evidently felt much at home. They doubtless fed on some of the small insects disdained by the spider. The genus Cyta is very similar to Bdella; our one species ( $C$. americana) occurs in damp fields; it was formerly known as Ammonia, which name is not only later, but also preoccupied.

\section{Family CHEYLETID A.}

The Cheyletidæ are a small family of tiny mites, differing considerably in habits and structure among themselves. The typical forms are distinguished by the enormous palpi attached to a distinct beak.

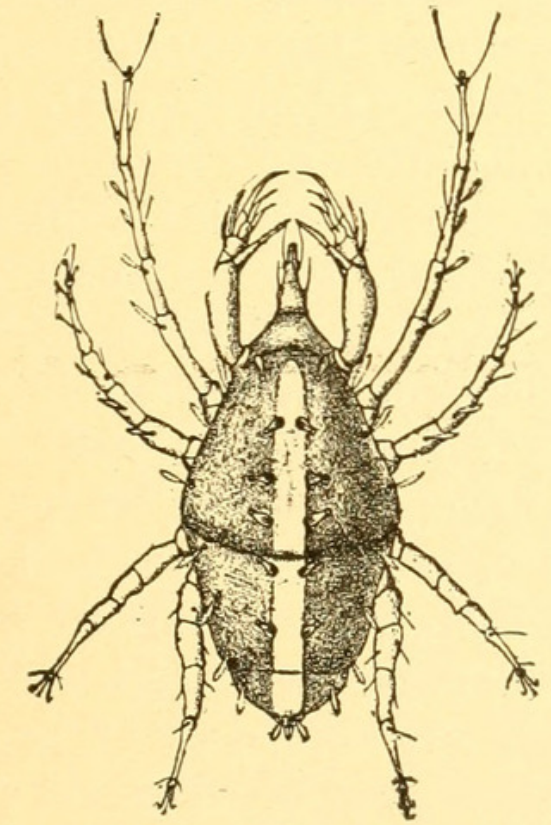

Fig. 16.-Chey letu's SP. (PERGANDE).

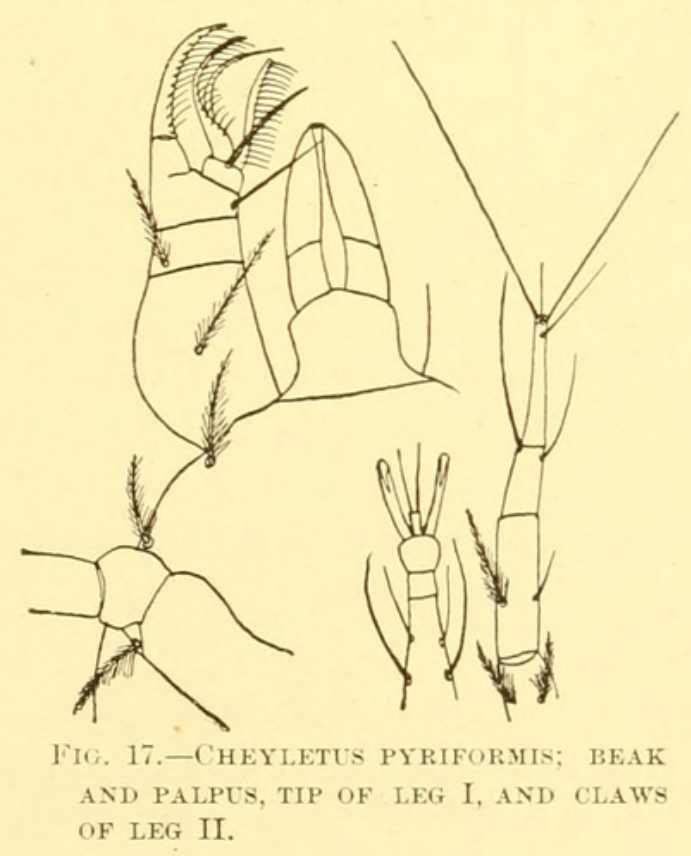

The palpi are three to five-jointed, and frequently have a minute movable tubercle or papilla near the tip on inner side, which in some forms is tipped with one or two pectinate bristles. This papilla is evidently homologous with the "thumb" of the Trombididæ. The beak is plainly

Proc. N. M. vol. xxviii- $04-2$ 
separated from the body by a deep constriction, and in front has the circular mouth-opening or camerostome, through which the mandibles may be extended and retracted. The body is usually oval; the skin soft, occasionally with chitinous plates, and in many forms finely striate. The division between the cephalothorax and abdomen is rarely present. The body bears a few hairs, sometimes in the form of scales. The legs are generally short, five-jointed, and usually end in two claws, with a bunch of hairs or a pectinate bristle between them. In some species the front legs terminate in bristles, and appear to have a tactile function; in others the front legs are transformed into clasping organs. Sometimes there is an eye on each side of the cephalothorax, but it is not often distinct. The mandi-

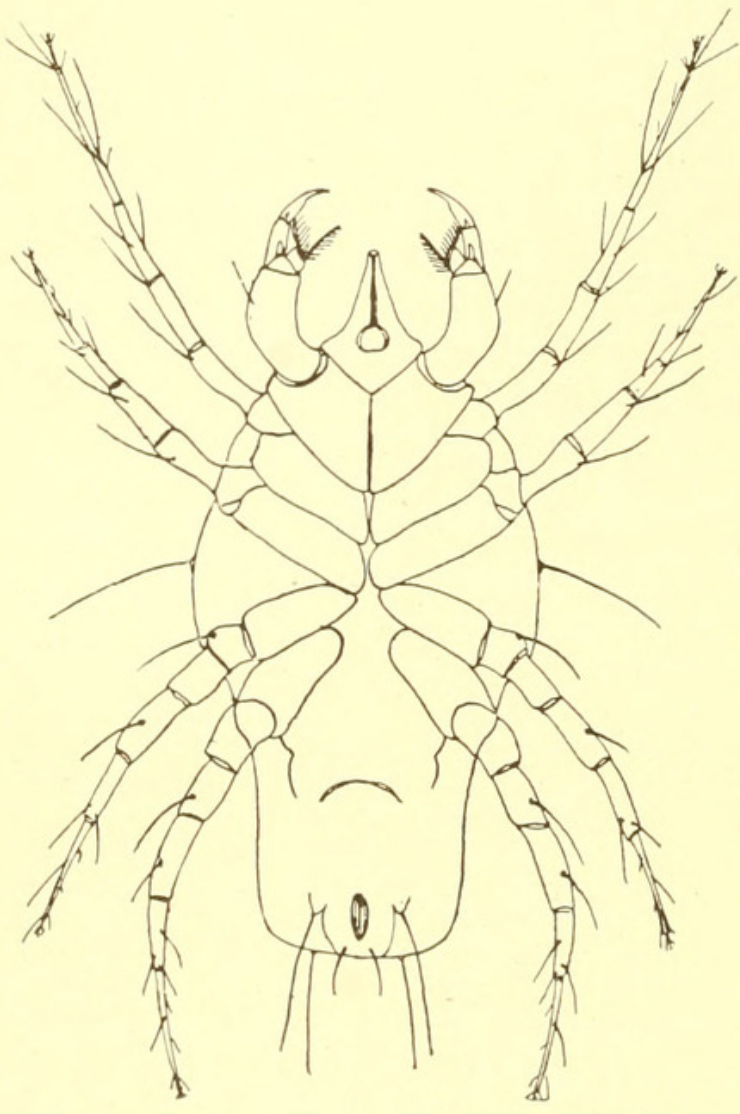

Fig. 18.-Cheyletus AUDAX, FroM BELOW. bles are commonly long and needle-like, fitted for piercing tissues; in one genus, however, they have two points, indicating their chelate origin. The female genital aperture is just in front of the anus, which is at tip of the venter. The male aperture is behind the anus, and often near the middle of the dorsum. The penis is very prominent, long, slender, and curved, and is often found partially extruded. The internal anatomy of the Cheyletidre has not been thoroughly examined. The digestive tube is simple; the stomach is provided with four large coea. In one genus, Sarcopterus, there is no anus; the food of this mite is of such a nature as to be completely digested. The respiratory system is perhaps more complete than that of other families. There are two large tracheal trunks starting from the beak and extending back to near the tip of the body, each giving off many smaller branches which ramify throughout the body. From some accounts it appears that the main trunks are composed of two or three separate tracheæ. These main trunks are connected to each other near their origins. The spiracles are at the sides of the beak, and in some cases there are two also near the median line. These spiracles are sometimes trumpet-shaped. The nervous system consists of a circle around the cesophagus and ten branches from it, four in front and six behind. Two of these branches go to the beak, others to the legs, and two to the posterior part of body. 
The eggs are deposited singly or in clusters, and by some species a web is spun over them, or at least a few threads to hold them in place. In a few species the mother remains to guard the cluster for some time. The larva, upon hatching, has much resemblance to the adult, but, of course, with only six legs. The nymph looks still more like the parent, and there are but few differences between the sexes, save that the male is smaller. Several authors have noted the existence of parthenogenesis in some species. Cheyletidæ feed on animal life, some being predaceous, others parasitic. A few may be said to belong to both groups, inasmuch as they occur upon certain animals only to prey on the parasites of the host.

Only a few genera are known, and of these but four have been recorded from this country.

1. Anterior leg fitted to clasp hair; hind legs with but one claw; palpi small ... Myobia Anterior legs not so modified; hind legs with two claws, or else leg I with two claws

2. Body elongate, at least three times as long as broad, palpi not swollen at base, no distinct "thumb" or papilla

Body not twice as long as broad, the papilla usually present. . . . . . . . . . . . 4

3. Anterior legs much larger than posterior pairs, and ending in a long bifid pulvillus . .

Picobia

Anterior legs barely longer than others, without such pulvillus...... Syringophilus

4. Body about as broad as long; legs very short and stout; palpi not swollen on outer side at base; parasitic forms. . . . . . . . . . . . . . . . . . . . . . . 5

Body plainly longer than broad; legs more slender; palpi usually swollen on outer side at base; hind legs with claws; not true parasites . . . . . . . . . . . . . . 6

5. Hind legs each with two claws ............................... Psorergates Hind legs without claws; with several long hairs.............. Harpyrhynchus

6. Tubercle, or papilla, of palpus with one or two pectinate bristles....... Cheyletus Tubercle, or papilla, of palpus with only simple hairs............. Cheyletiella

Cheyletus contains about one dozen species. They are very small (about one-half millimeter in length), live freely, and prey upon other mites and small insects. They seize the prey with their big palpi, insert the mandibles, and suck it dry. Some have thought that there must be poison glands in the palpi, since the prey ceases movement very soon after capture. Several species have some fan-shaped hairs or scales on the body and appendages. These constitute the subgenus Cheyletia Haller. Two species, one of them, C. clavispimus Banks, hare been found attached, in adult condition, to Hemiptera of the genus Aradus. They are evidently not parasitic, but use the insect only for transportation. Another of our species, C. pyriformis, was found feeding on a scale insect on grapevine, another on Cicada eggs, and a third, $C$. audax, attacking Tyroglyphids among cabbage seed. Cheyletiella includes several species in which the palpi are not as large as in Cheyletus. They usually occur on birds where they feed on the other mites present. They have been called auxiliary parasites. One species, $C$. parasitivorax, uses the rabbit's fur as a hunting forest, 
where it destroys the Listrophorus mites. No species have as yet been recorded from this country. Harpyrhynchus (formerly Sarcoptemus) is represented by a few species that have a very short, broad

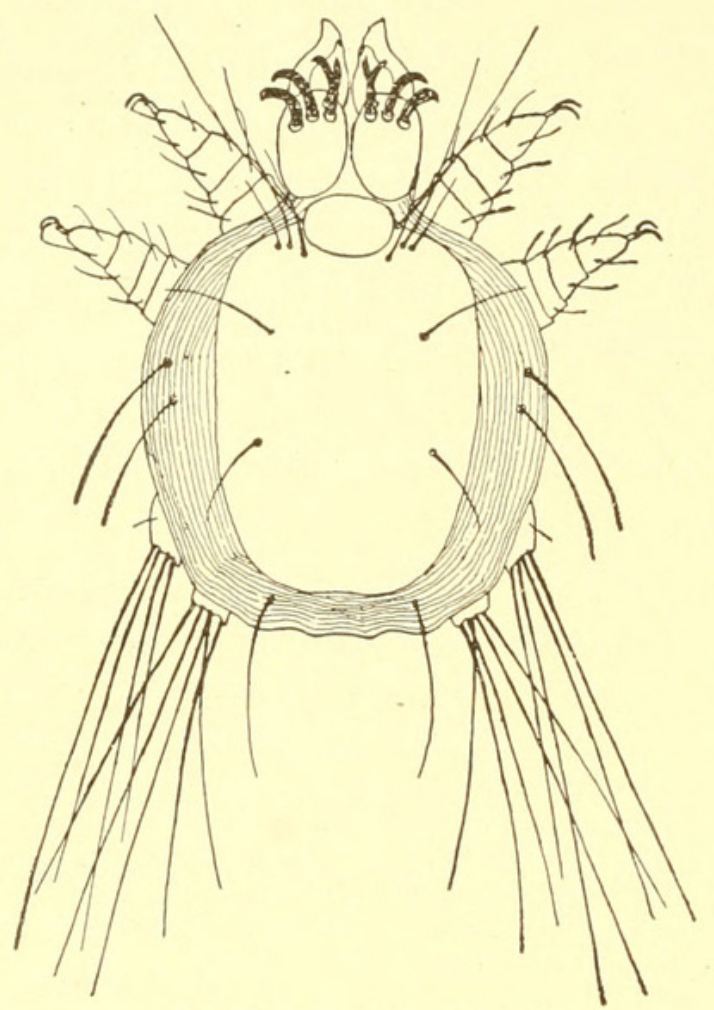

Fig. 19.-HARPYRHYNCHUS LONGIPILUS, FEMALE. body, with very short legs, the hind pairs ending in a bunch of bristles. They occur in the hair follicles of several birds, where they form tumors. The eggs are very large for

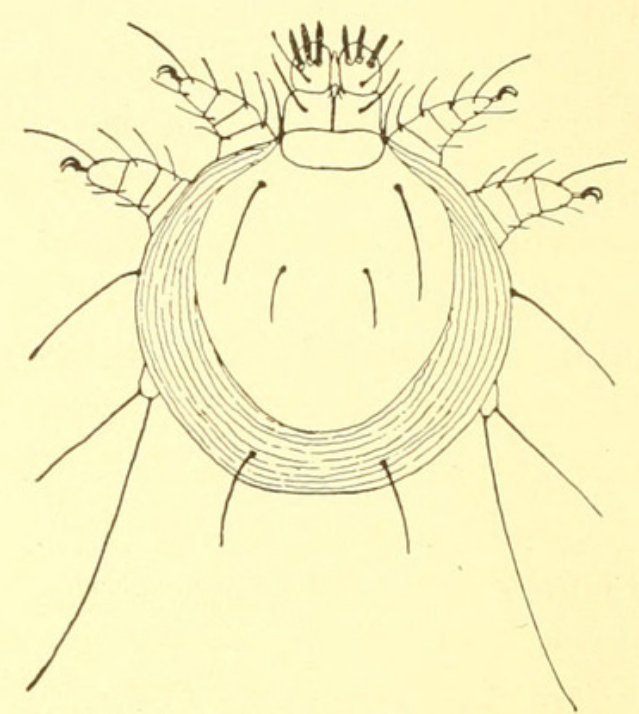

Fig. 20.-HARPYRHYNCHUS LONGIPILUS, IARVA.

the size of the mite. One species, II. Tongipitus Banks, has been taken in the United States in a tumor under the wing of a cross-bill. The

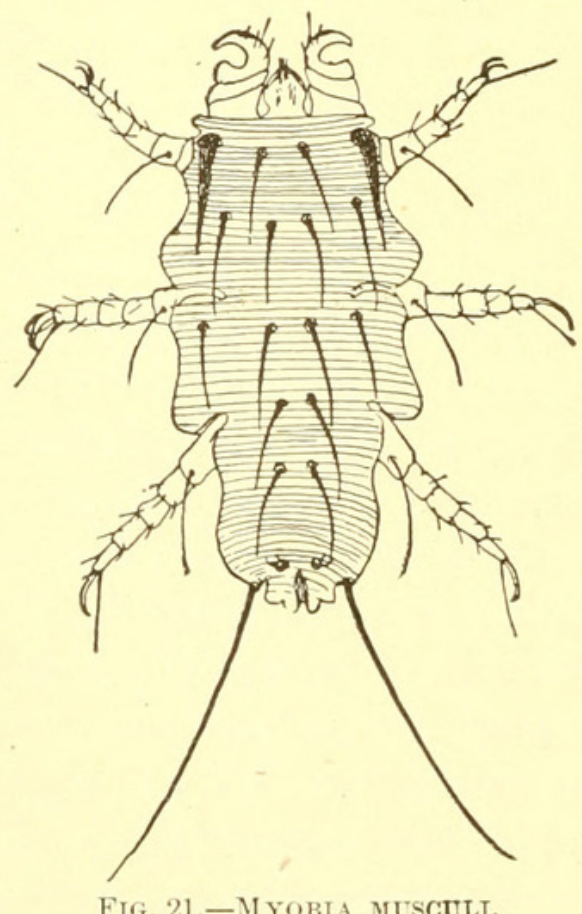

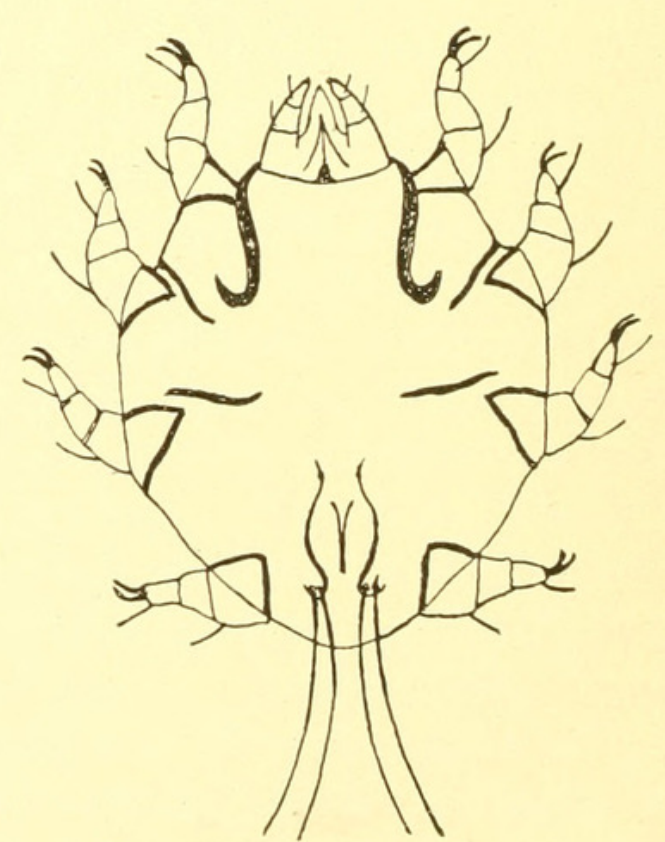

Fig. 22.-Psorergates SIMPLEX.

genus Psorergates was described by Tyrrell from Canada. It lives parasitically on the house and field mouse, in cavities or little cells just beneath the surface of the skin. It has a nearly round body, 
with very short, stout legs, each ending in two stout claws. It has since been found in various parts of Europe, and was described by Michael under the name of Gonionems musculimus.

The genus Myobia was based on a species from the head of the house mouse. All the legs are very short and thick, but the first pair is heavier than the others and transformed into an organ fitted to grasp the hair. The eggs are fastened to the hair of the mouse. The nymph differs considerably from larva and adult in legs and beak. The palpi are atrophied. In this stage it burrows into the hair follicles, feeds there, and transforms. It is not supposed to suck blood, but to feed on matter secreted by the skin cf the host. Several other species are found on allied mammals, and one infests bats. Osborn has recorded the presence of $\boldsymbol{M}$. musculi in this country.

Picobia and Syringophilus are closely allied. They have elongate bodies provided with long bristles. They live in the quills of the feathers of various birds, coming out only for breeding and migration. One of these was recorded from Arizona by Hancock as Picobia villosa, which Trouessart states is the same as S. bipectinatus Heller of Europe. Trouessart also claims that this is not an adult mite, but that it is a stage (which he calls "syringobial") in the life of a Cheyletiella. Nörner, however, describes and figures the male and egg of this species.

\section{Family ERYTHRAID E.}

There are few species of mites in this family, but one is very common and beneficial. They are at once separated from all other Trombidoidea in that the coxæ are close together and arranged in a radiate manner. The body shows no complete division between cephalothorax and abdomen, although in the typical genus the division is often indicated just behind the third pair of legs. The body, which is usually short and broad, is provided with many stout bristles. In front on each side are one or two simple eyes. The mandibles are quite large and prominent and taper to a point which is tipped by a curved claw. The palpi are prominent, but slender; in Erythrous with a long "thumb," but in Anystis the last joint is terminal. The legs are large and long, gradually tapering and provided with many long hairs or bristles.

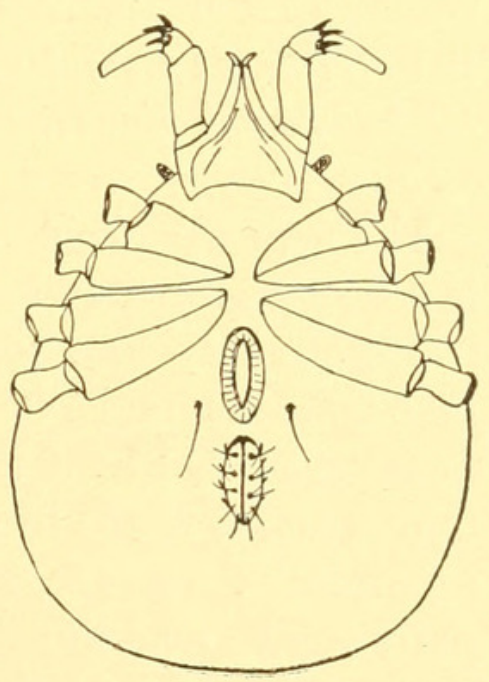

Fig. 23.-Venter of ANystis. They are six or seven jointed, and terminate in two or three claws. In some species the tarsus is divided into a number of small joints. On the venter are genital and anal openings, both quite elongate. The young resemble the adult, except in having but six legs. 
There are four genera, three of which, Erythrous, Anystis (formerly Actineda), and Gekobia, are known from the United States. Anystis and Erythreus are free and predaceous, feeding on any small insects or acari that they may come across. Their movements are excessively

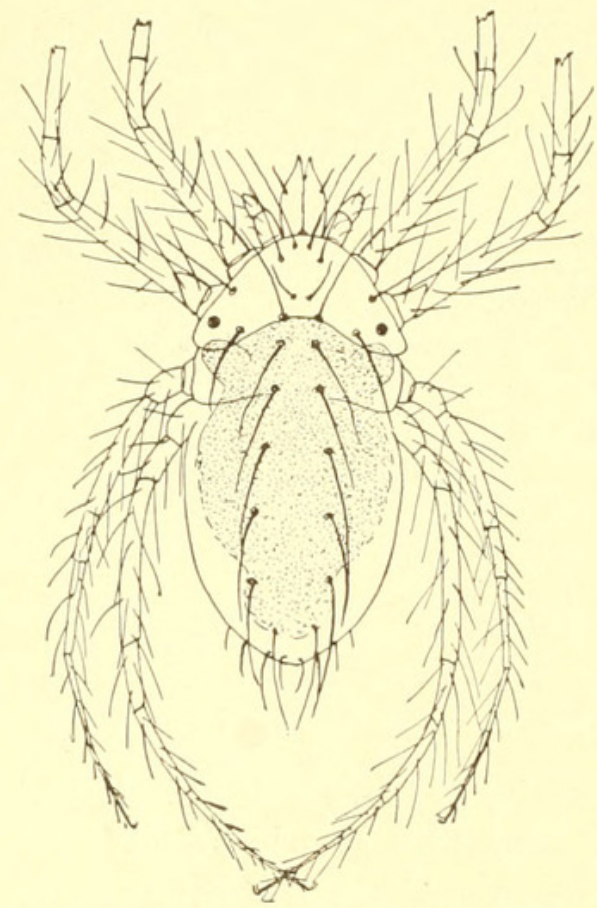

Fig. 24.-ERythreus SPINATUS. rapid and erratic, sometimes whirling about in a zigzag course like a particle of dust blown by the wind. In Anystis the body is triangular and the palpi are four-jointed. In Erythraus the body is more elongate, and the palpi five-jointed.

Our one species of Anystis, A. agitis Banks, is commonly found running over the leares of herbs and shrubs in the search for prey. It is red in color. I have seen it feed on aphids, on small caterpillars, and on the young larve of the currant saw-fly. The young before transformation spins a white silken web on a leaf, or crevice of bark, and beneath it changes to the adult form.

Species of Erythraes are known to occur about houses, but most of them

live on trees. They are usually red in color, but some are marked with white spots and stripes. They are not very common in our country, but two species have been described. Gekobin is found attached to various reptiles, especially lizards. Three species are known from Europe, and one, $G$. texana, is found on Sceloporus floridanus in this country.

The typical species is very broad, broader than long, and the coxæ all close together; in $G$. texana and one European species the body is longer than broad and the hind coxæ separated from the anterior pairs. The mandibles have a peculiar structure; they consist of a stout rod with a short, acute, stout spur near the tip. They are supposed to

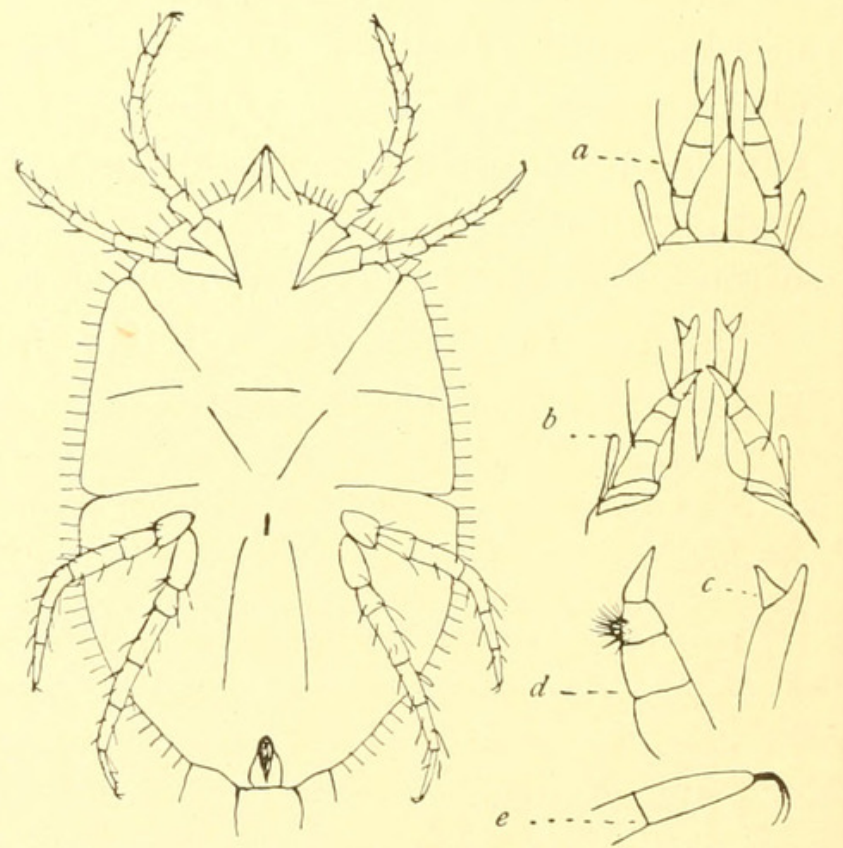

FIG. 25.-GEKOBIA TEXANA. $a$, BEAK ABOVE; $b$, BEAK BELOW; $c$, TIP OF MANDIBLES; $d$, PALPUS; $e$, TARSUS WITH CLAWS.

suck blood from the lizards; nothing is known of their earlier stages.

Berlese has recently changed Erythrous to Erythacarus, claiming that the type of Erythrous is a Rhyncholophus. 


\section{Family TETRANYCHID E.}

The members of this family, commonly known as "red spiders," have for many years attracted attention, owing to their ravages to cultivated plants. Since many of the species can spin a silken thread, they have also been called "spinning mites." Their structure presents few remarkable characters. The body is oval or elliptical, provided with a few, mostly long, hairs, arranged in four rows. The cephalothorax is separated from the abdomen by a furrow, and bears on each side one or two simple eyes. The palpi are short, the penultimate joint ending in a claw. The last is "thumb-like" and bears one or more appendages called "fingers." In some species the palpus of the male has a short curved spine at the tip on the upper side of the third joint. The mandibles have their basal joints united in a plate; the apical joint, being very long and flexible, is fitted for piercing plant tissues, and is known as the stylet. The legs are moderately slender, the first pair the longest, with scattered hairs, and ending in one or two claws. In many species of Tetranychus the claw is split into four pieces, whence the name. On the under side of the abdomen are two

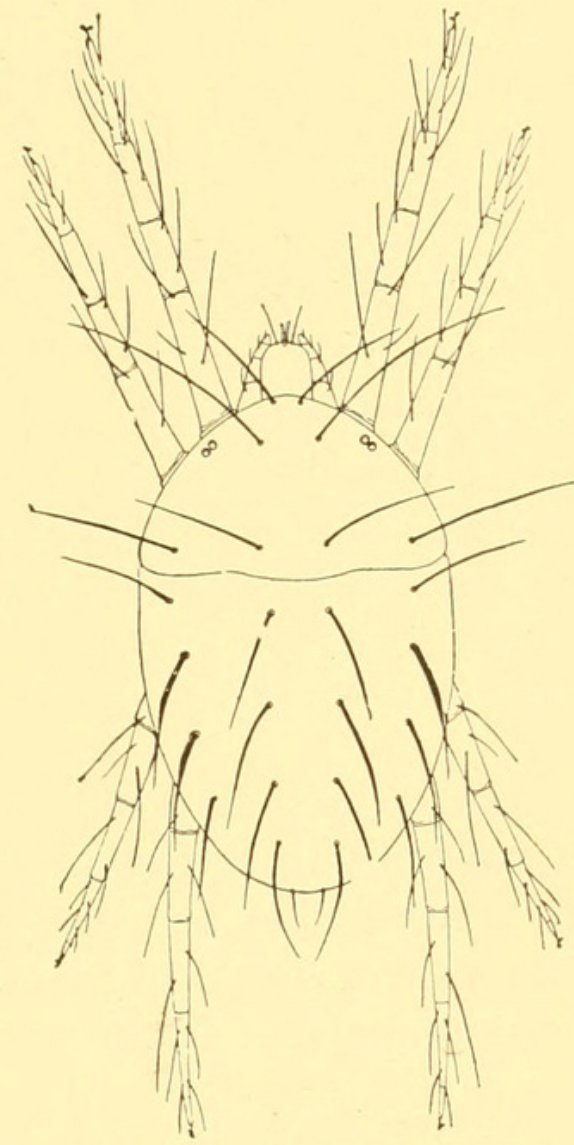

Fig, 26,-TETRANYCHUS BIMACULATUS. simple openings, the basal the genital, the other the anal. The former in the female is usually transverse. In the male it is longitudinal and often shows the slender curved penis.

The genera recognized in our country may be separated as follows:

1. Front margin of cephalothorax with four scale-like projections, body with scalelike hairs above; leg I longer than body ....................... Bryobia.

No scale-like projections on front of cephalothorax . . . . . . . . . . . . . . . . . 2.

2. All the legs much longer than body, which is short and broad; rostrum not prominent from above................................. Neophyllobius

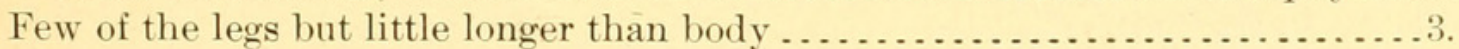

3. Palpi ending in a distinct "thumb;" not very slender....................

Palpi not ending in a distinct "thumb" ................................

4. Palpi very small and slender; legs short and heavy, usually rugose; eyes distinct

Tenuipalpus.

Palpi of moderate size, legs longer, not rugose; eyes indistinct or absent ........

Tetranychoides.

5. Body twice as long as broad; legs very short.................... Stigmæus.

Body one and one-half times as long as broad; leg I longer than body . . . . . . . . . 
Two coirimon European genera, Caligomus and Raphignathes, have not been found in this country. They are very small and of a bright red color. In the genus Bryobia we have but one species, B. pratensis Garman, known as the clover-mite. It is very abundant in many localities. In the West it is injurious to fruit trees; in the East

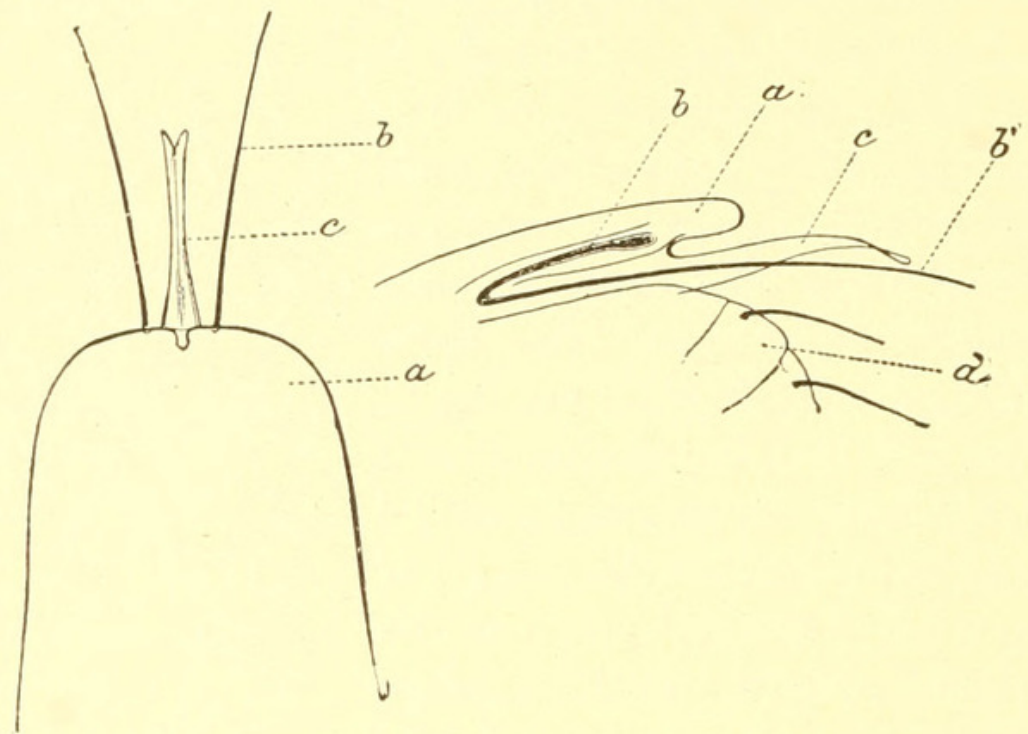

Fig. 27.-Tetranychus, Mandibular plate, dorsal and lateral views. $a$, Plate; $b$, Stylet; $c$, SPINA; $d$, PALPUS.

it more commonly affects clover and annual plants. The eggs are laid in the autumn in great numbers, attached to the branches and twigs of trees. They are red, very small, and round, and are often mistaken for the eggs of plant-lice. The adults in the autumn often seek winter quarters in houses and may become a great nuisance. Both

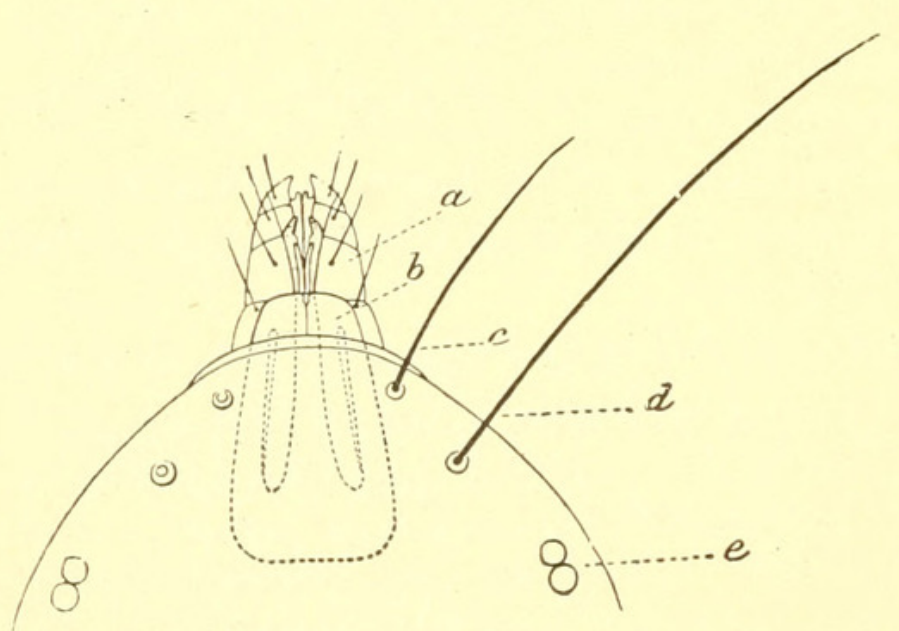

Fig. 28.-TETRANYCHUS, CEPHALOTHORAX FROM ABOVE. $a$, PALPUS; $b$, MANDIBLLAR PLATE; $c$, FRONTAL BRISTLE; $d$, SUBFRONTAL BRISTLE; $\ell$, EYES. the mites and their egos can be killed by a spray of kerosene emulsion.

In Tetranychus the body is subpyriform, and provided above with about twenty-four to thirty-six bristles arranged in four rows. The species of this genus can spin a thread, which, when they are very abundant, becomes a dense mesh or web, visible at a considerable distance. The spinning organ is not definitely located, but the thread arises from or near the genital or anal opening. The web does not appear to afford the mites any protection, but at times seems to serve to hold the eggs in place. It may be either on the upper or lower surface of the leaf. The mites are supposed to hibernate under or among fallen leaves, in the spring ascending trees to start new colonies. 
Each female may lay from five to ten egg's a day for a period of eight to twelve days; the young hatch in from three to five days, and in about five days more are adult. A succession of broods is continued

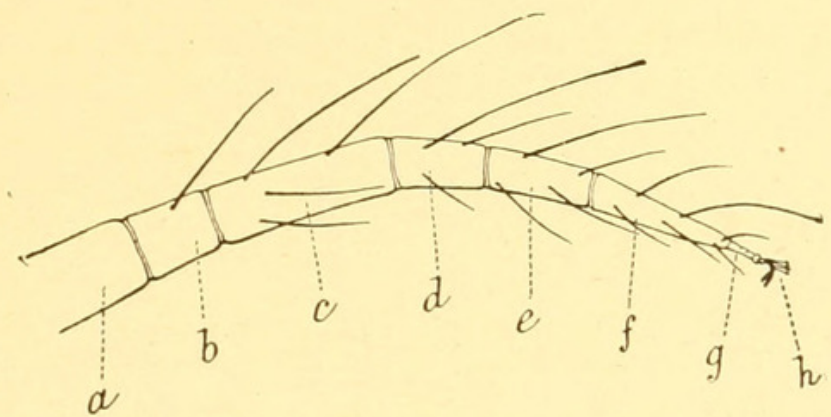

Fig. 29.-Tetranychus leg. $a$, coxa; $b$, trochanter; $c$, Femur; $d$, Patella; $e$, tibia; $f$, tarsus; $g$, ONYCHIU; $h$, CLAWS.

throughout the summer, but wet weather is apt to stop or greatly retard their development.

The mites ordinarily move slowly, but when disturbed can run quite rapidly. For the greater part of the time they remain in one place
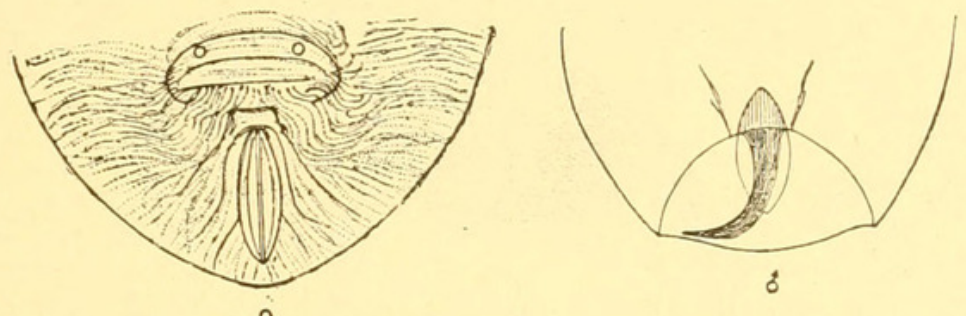

Fig. 30.-Tetranychus, genital organs.

sucking the juices from the leaf. In the spring some species attack the buds. Several of our species are very abundant and destructive. The common greenhouse species, known as "the red-spider," and which also occurs on many outdoor cultivated plants, is T. bimaculatus
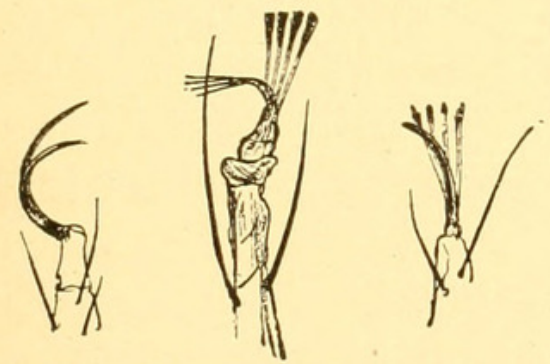

Fig. 31.-THREE STYLES OF CLAWS OF TETRANYCHUS
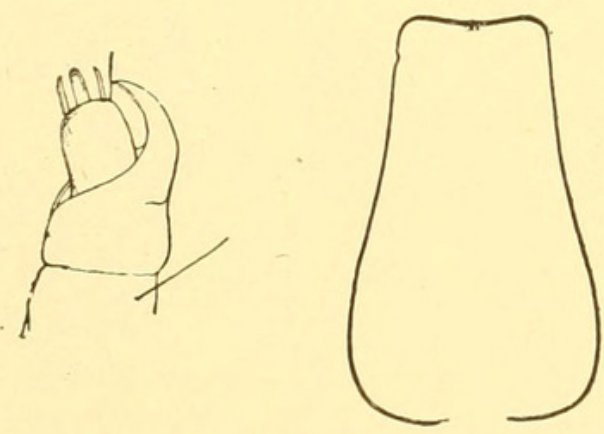

Fig. 32.-Tetranychus gloveri, PALPUS AND MANDIBULAR PLATE.

Harvey; it is probably the T. cucumeris of Boisduval. Specimens of this species often vary greatly in coloration; the members of each colony, however, usually being alike. T. mytilaspidis Riley is abundant on orange leaves in Florida. In this species the abdominal bristles arise from warts or tubercles, and the tarsus has two simple 
claws. The most abundant species on orange is a yellowish form, T. sexmaculatus Riley. At times it is a very serious pest to orange culture, and an article upon it is found in the Report of the Ento-

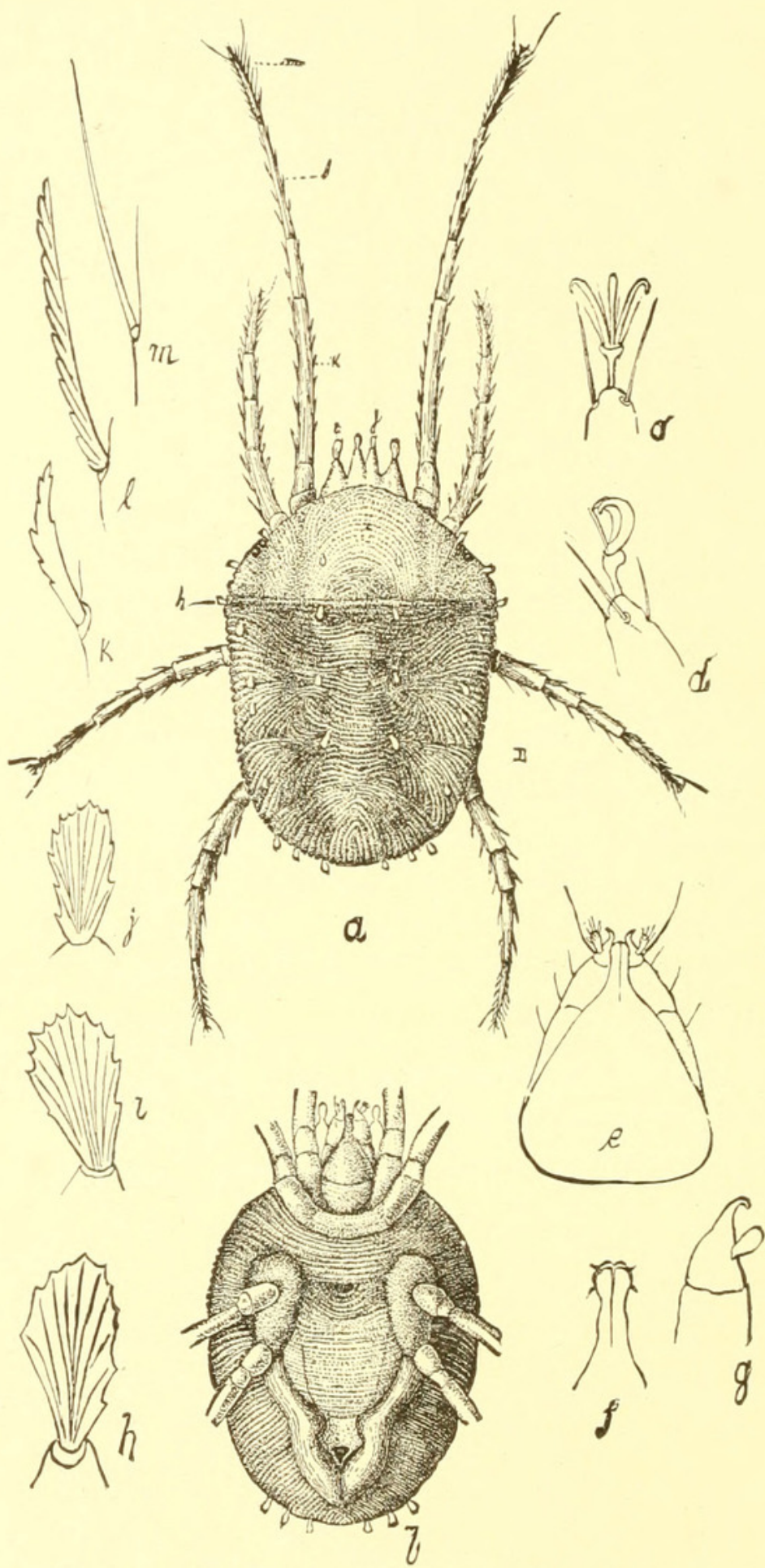

Fig. 33. Bryobia pratensis- $a$, Female from above; $b$, female from below; $c$ and $d$, tarsai CLAWS; $e$, BEAK FROM BELOW; $f$, BEAK FrOM ABOVE; $g$, PALPUS; $h, i, j, k, l, m$, sCALES AND SPINES OF VARYING SHAPE (BUREAU OF ENTOMOLOGY).

mologist for 1889 . They occur on the under surface of the leaves; the eggs are colorless or pale greenish-yellow.

In T. bicolor Banks, a species common on the leaves of oak and chestnut, the tarsus has but one claw. The form occurring on cotton is known as T. gloveri Banks; it is bright red, and greatly resembles 
the common greenhouse species. There are several remedies for red spider. One is to keep the plants moist, spraying them with water once a day. But the best remedy is flowers of sulphur applied either as a dry powder, or as a spray. Bisulphide of lime is also an effective remedy, and tobacco water is sometimes used. The species of Stigmzus are

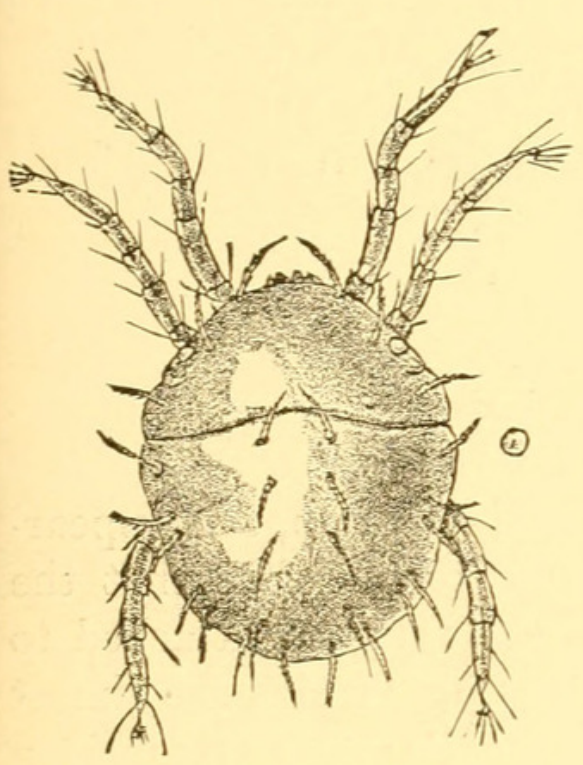

Fig. 34.-BRyobia PRATENSIS, LARVA (BUREAU OF ENTOMOLOGY).

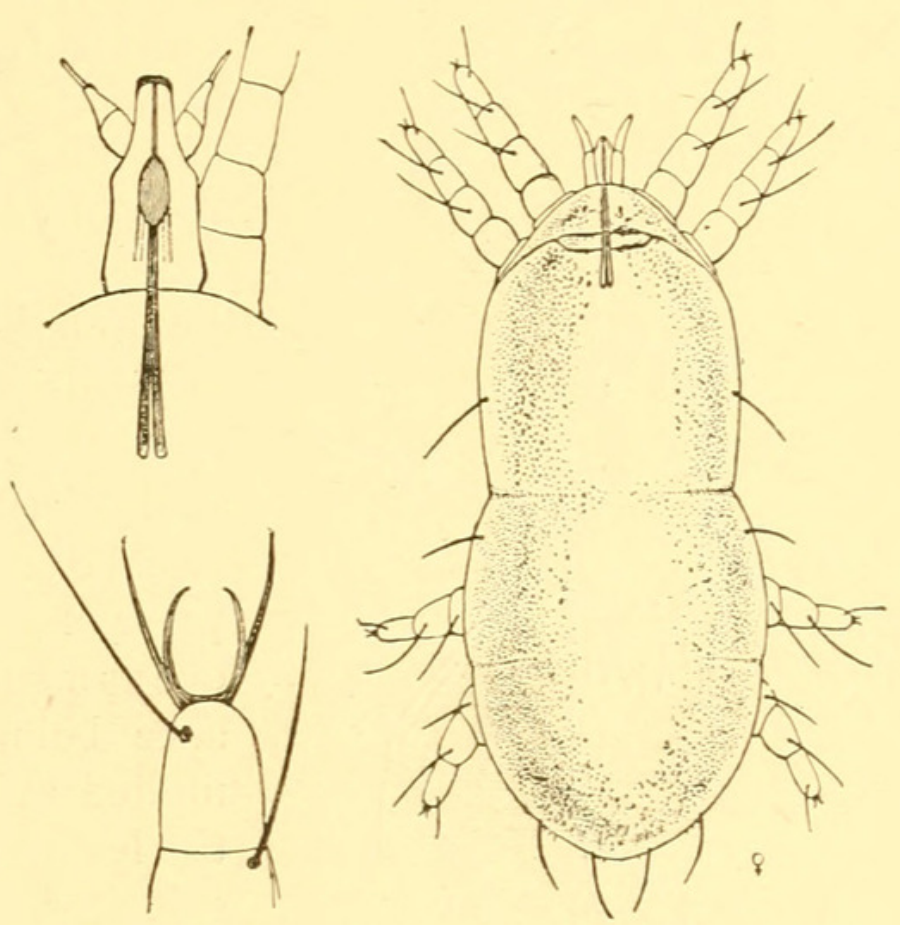

Fig. 35.-STigMAEUS FLoridaNUS; Mite, MOUTH PARTS, AND CLAWS.

elongate and have short legs. They are smaller than Tetranychus, but live in the same manner. Our one species, S. floridanus Banks, occurs upon the bases of the imbricated leaves of the pineapple. It

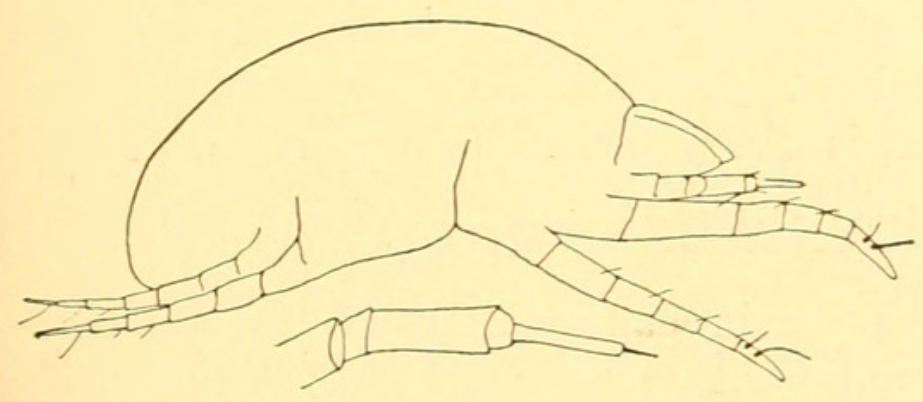

Fig. 36.-TetraNychoides CALIForNica, AND PALPUS ENLARGED.

is of considerable economic importance owing to the fact that its punctures give certain destructive fungi access to the tissue of the leaf. The remedy, Prof. Rolfs found, is to place a small quantity of tobacco dust in the bud of

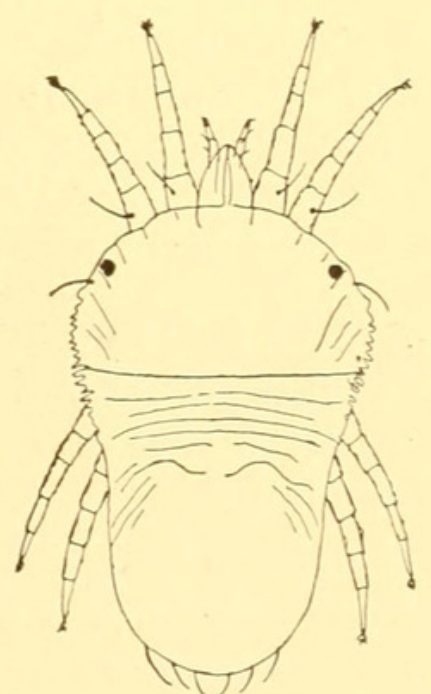

Fig. 37.-TeNuipalpus CaLIFORNICUS, the plant, the dew and rain washing it down upon the mites. One application is usually sufficient.

In Neophyllobius the body is short and the legs are very long; the tarsal joint slightly swollen in the middle and ending in two claws. Our only known species was taken on oak leaves in Alabama. 
In Tenuipalpus the palpi are very small and slender, and end in two or four short bristles. The species are smaller than Tetranychus, and red in color. I have seen one species from our country, namely,

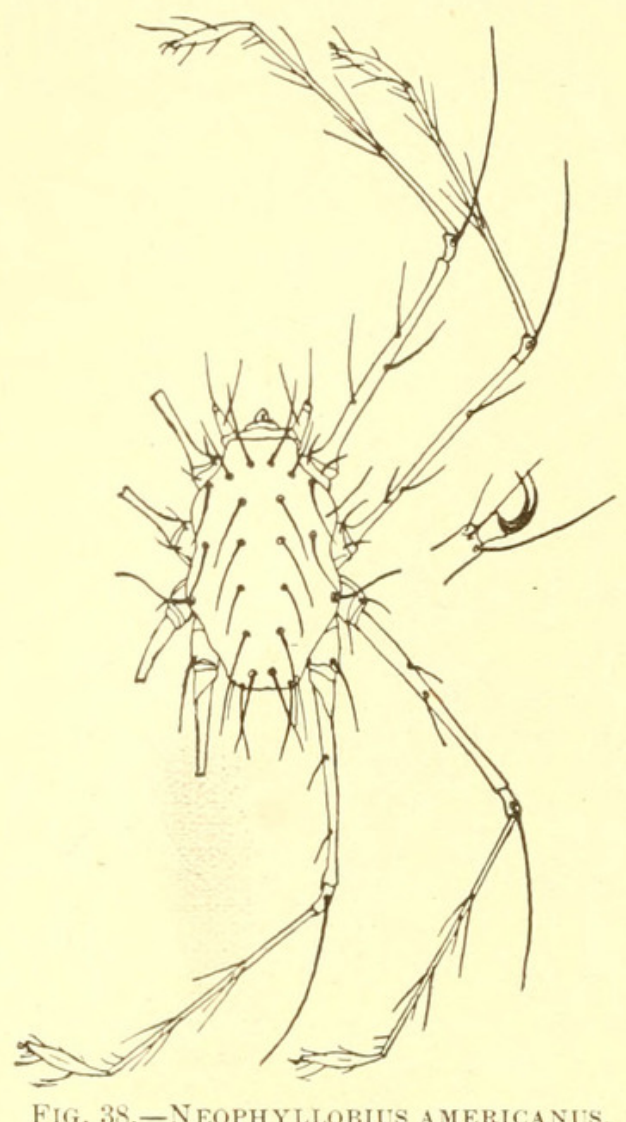
Temipalpus californicus. It appears to be very numerous on the oranges in California, and doubtless causes some injury. Inasmuch as it is very small, and does not breed very fast, it will probably never be a pest of prime importance. It may be destroyed by the treatment used against "red-spider."

Tetranychoides is based upon one species, T. californica, which occurs in small colonies on the leaves of orange. Each colony is usually in a slight depression, and is evident to the naked eye as a snow-white patch, this appearance being due to the fact that the molted skins are retained attached to the leaf. The mites, which are almost colorless, and their eggs, are located among these molted skins. They do not appear as yet to be numerous enough to do any appreciable damage.

Three other genera have been recorded in Europe, Eupalopsis, Cryptognathus, and Tetranychopsis, each with but one or two species.

Red-spider damage is common in nearly all foreign countries, but the genieric positions of the mites that cause it are not easily discernible from the meager descriptions. In India and Ceylon one species, called Tetranychus bioculatus, is a very serious pest to the tea plant.

\section{Family RHYNCHOLOPHID A.}

These common mites are similar in many ways to the harvest-mites (Trombidiidæ) and by many authors have been united to them. They are much like Trombidium in appearance, but nearly all are of more slender proportions and more rapid in motion. The body is usually divided, although not so plainly as in the Trombidiidæ, into two parts. The cephalothorax is quite large and on the same plane as the abdomen. Along the middle of the cephalothorax is a line or furrow, known as the dorsal groove or crista. It is usually enlarged at the posterior end, sometimes in the middle, and also at the anterior end, where it often includes a frontal tubercle. There are one or two simple eyes on each side of the cephalothorax; they are always sessile. In one genus (Smaris) there are also two eyes close together near the middle of the anterior margin. The palpi are prominent, five-jointed, the last forming a "thumb" to the preceding, which ends in a claw. 
The mandibles are slender, needle-like, and retractile, thus differing greatly from those of Trombidium, and forming the warrant for a separate family.

The legs are commonly quite slender, the hind pair sometimes more than twice as long as the body. They are seven-jointed and terminate in two small claws. The last joint, or tarsus, is nearly always shorter than the preceding joint, and in the first and fourth pairs often swollen. The body and legs are densely covered with bristles or hairs, sometimes both. The hinder pair of legs are always quite remote from the anterior pairs. The genital opening is between the hind coxæ; the anal opening is usually close behind it.

They are usually found on the ground, sometimes in very hot situations, and run over the surface or on low plants with great rapidity. Other species occur in moss or under

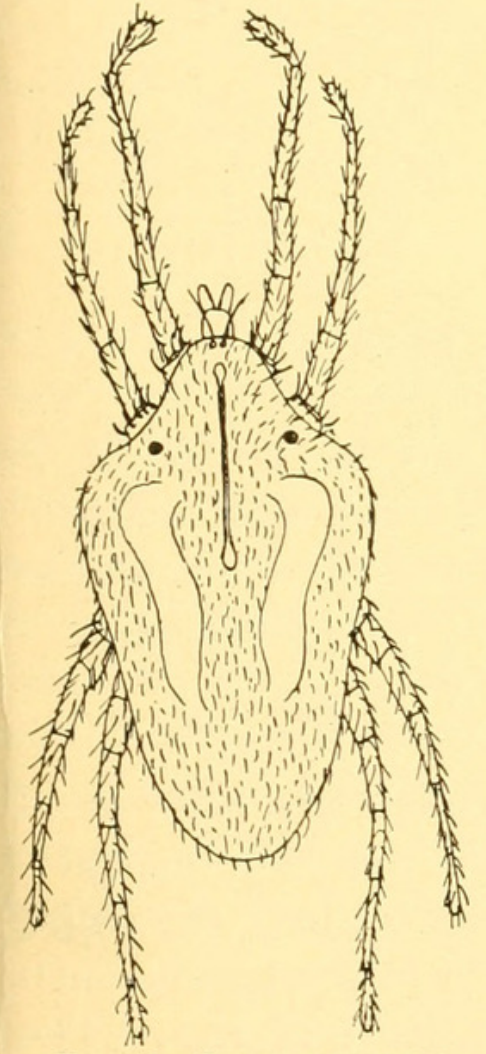

Fig. 40.-RHYNCHOLOPHUS MACULATUS.

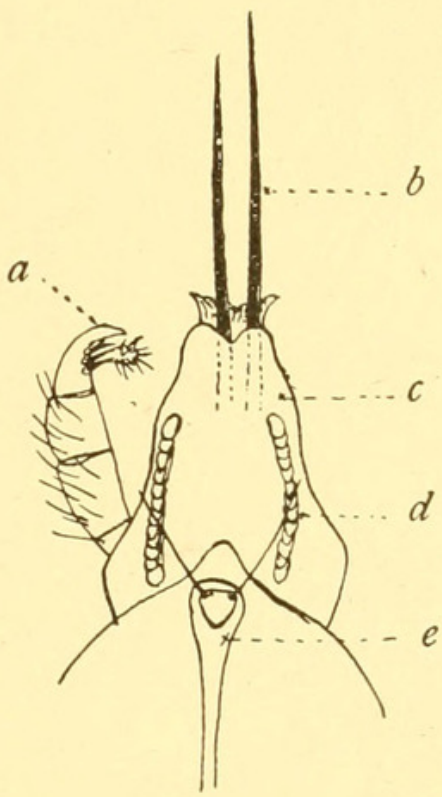

and one is abundant among the rocks near the top of Mount Washington. Several species appear to live in colonies, but most are solitary in habit. The eggs are deposited on the ground or un-

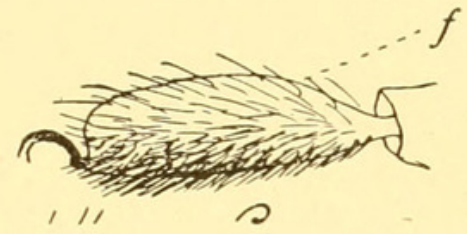

Fig. 39.-RhyNCholophus. $a$, PALPUS; $b$, MANDIBLES; $c$, BEAK $d$, TRACHEAL PORES; $e$, DORSAI. GROOVE; $f$, TARSLS. der stones, often in clusters. The larva is a six-legged mite attached to insects. When full fed they drop to the ground and become quiescent, and after a varying time transform to the adult.

There are several genera in the family, but only three are so far known from the United States. In Smaris the mouth-parts are retractile, and so are often invisible; the palpi are four-jointed and there is commonly an extra pair of eyes near the anterior margin, making six in all. In Smaridia the mouth-parts are less retractile than in Smaris, and there are but four eyes. The palpi are five-jointed and the dorsal groove is sometimes swollen in the middle.

Thor, who has recently published on this and allied families, makes Smuris the type of a special family. He finds that in this genus there are no spiracles near the beak, as in other Prostigmata, and that there are no large tracheal trunks in the body. There are a great many fine 
tracheæ in this mite, and Thor believes that respiration is effected through the skin, the structure of which is rather peculiar. Upon these differences he bases a family; however, in my opinion, this is but more evidence (if such is needed) of the uselessness of a classifi-

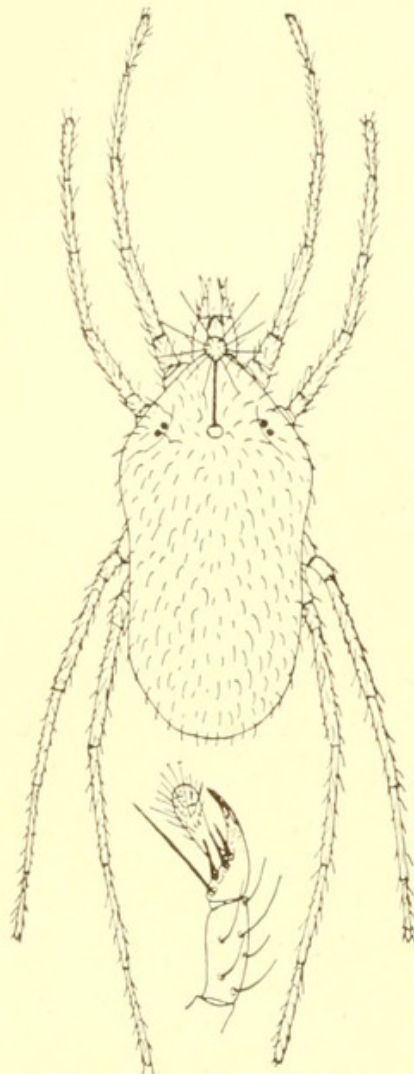

FIG, 41.-RHYNCHOLOPHU SIMPLEX AND PALPUS. cation based on the respiratory system.

In Rhyncholophus the mandibles only are retractile; there are but four eyes, and the palpi are five-jointed. We have many species of this genus, and several of them are common and widely distributed. They are predaceous and suck the juices from any small insect that they are able to catch. One species has been found preying on the gloomy scale (Aspidiotus tenebricosus) and othersare found feeding on the San Jose scale and other scale insects. In these situations they are often the prey of aphis-lions (Chrysopa).

Most of our species are uniform red in color, but R. cinctipes Banks has prettily banded legs, and

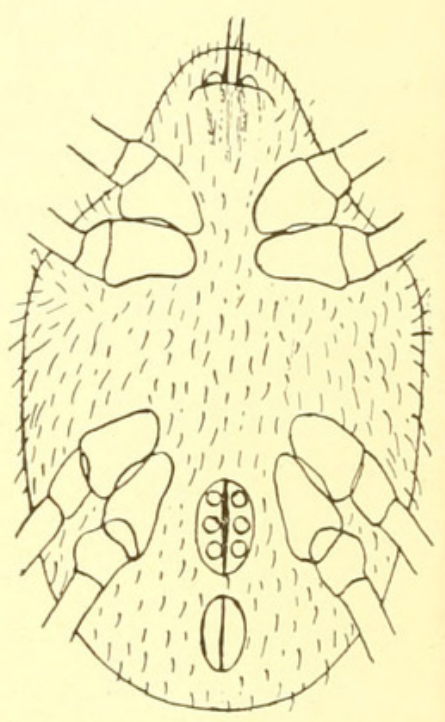

FIG. 42.-VENTER OF SMARIS, R. maculatus Banks has

several large pale spots on the dorsum. One of our species, R. longipes, has so extremely long legs that it resembles a minute Phalangid. The genus Eatoniana occurs in southern Europe and northern Africa; it is remarkable on account of the plume of hairs on the hind legs.

\section{Family TROMBIDIIDA.}

The "harvest mites," as they are popularly called, are recognized by the body being divided into two portions, the anterior (cephalothorax) bearing the two anterior pairs of legs, the palpi,

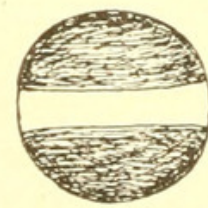

FIG. 43.-EGG OF Trombidium. mouth-parts, and eyes; the posterior (abdomen) is much larger and bears the two posterior pairs of legs. The mandibles are chelate, at least there is a distinct jaw or curved spine-like process. They also differ from the allied Rhyncholophidæ in that the last joint of leg IV is not or very slightly shorter than the penultimate, and in that the last joint of $\operatorname{leg} \mathrm{IV}$ is not swollen. The last joint of leg I usually is swollen, often more so than in the Rhyncholophidæ. They are always red in color, some, however, being much darker than others. The body is covered with bristles or feathered hairs according to the species. The palpi are five-jointed, quite prominent, often swollen in 
middle, the penultimate joint ending in one or two claws, the last joint (often clavate) appearing as an appendage or "thumb" to the preceding joint. The legs are seven-jointed; the tarsi terminate in two small claws. The legs are clothed in the same manner as the body. There are two eyes upon each side of the cephalothorax, quite frequently borne on a distinct pedicel. Along the median line of the cephalothorax there is commonly a crista or dorsal groove similar to that of the Rhyncholophidæ. This crista is enlarged at the middle or posterior end into a triangular area, called the areola, in which are two pores from which arise bristles.

Doctor Oudemans terms these pseudo-

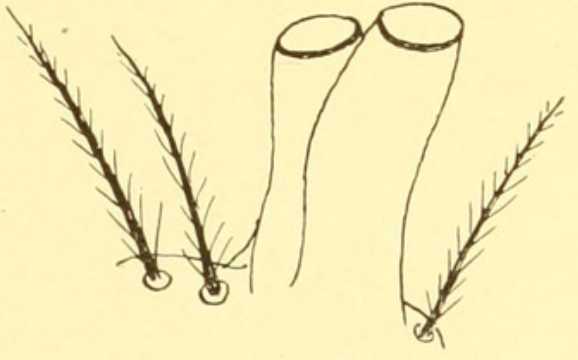

Fig. 44.-Eye of Trombidium. stigmata and pseudostigmatic organs. The latter are sometimes clavate at or near tip. There is no proof that these are homologous with the organs of the same name in the Oribatidæ, although it is possible.

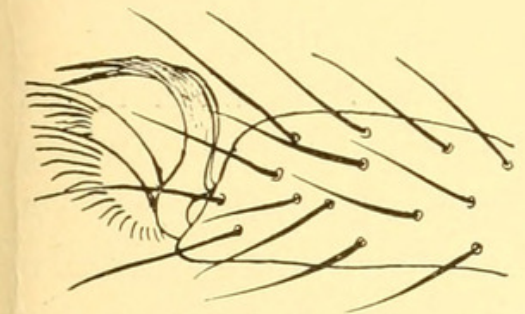

Fig, 45.-Claws of Trombidium.

Sometimes these organs are present, although the crista is absent, and in one species there are two pairs of the organs. The function of these organs is entirely unknown. The genital aperture is situate between the hind coxæ; the anal opening is smaller than the genital and placed a little behind it.

The larve are six-legged mites and parasitic on various insects. They, with other larval forms, were formerly supposed to be adult and to constitute a distinct family under the name of Microphthiridæ. Three of the genera of that family, Leptus, Ocypetus, and Atoma (or Astoma), are now known to be larval Trombidiids. Some of these larvæ are, in certain localities, very numerous, and will attach themselves to man, causing in-

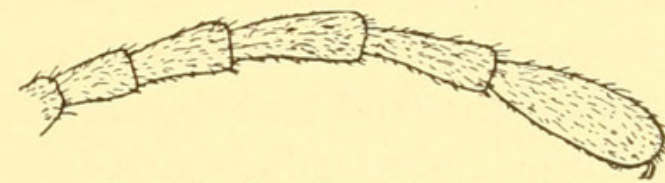

FIG. 46.-LEG I OF TROMBIDIUM. tense itching, soreness, and even more serious complications. They have received the popular name of "red bug." In parts of the Southern States the "red bug" is often a source of great annoyance. They burrow beneath the skin and produce inflamed spots. It is an unnatural situation for the mites, and they soon die, but the waiting is not pleasant. They can be killed by anointing the affected spots with an ointment or salve containing sulphur. Some recommend sponging with a veak solution of car-

Fig. 47.-Mandible of Trombidium. $p$, TRACHEAL PORES; $t$, TRACHEA.

bolic acid (an ounce to a quart of water) after a soap bath. Allied species occur in most warm countries. In France, where they are often very troublesome, they are called "rouget" or "aoutat," and are the 
cause of the "erythema autumnale." In parts of Germany a severe infestation is known as "Stachelbeerkrantheit." In England and Scotland it is called the "harvest mite" and "gooseberry bug." In Mexico red bugs are known as "Tlalsahuate," in Japan as " Akamushi," and in

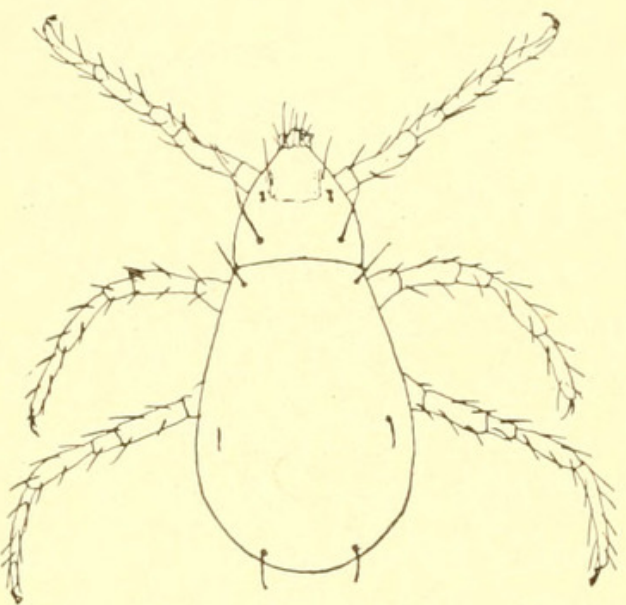

Fig. 48.-The LARVA (Leptus) OF a TromBIDIUM. parts of the West Indies as the "bêterouge." In all these countries they have at times been a serious annoyance to the peasantry and hindered or prevented the harvesting of certain crops. The female deposits the eggs in or upon the ground, sometimes as many as 400 together. They are usually brown and spherical, and were by some early writers considered to be fungi. The outer skin or chlorion soon splits, dividing the egg into halves and exposing the pale vitteline membrane. This stage is the "deutovum" of Claparede.

The newly-hatched larva is circular or ovoid in outline, with three pairs of legs, each tipped with two or three prominent claws. After becoming attached to the insect the larva becomes elongate and swollen with food. When full fed it drops off, seeks shelter, and gradually changes in shape, but does not molt. The new parts are formed under the larval skin, which in a few weeks cracks and discloses the adult Trombidium.

The mature mite is not parasitic, but wanders about feeding on small insects, as plant-lice, young caterpillars, and one species, T. locustamm Riley, is known to destroy a great many grasshopper eggs. A French species has been found destroying the root-forms of the dreaded Phylloxera. The adult hibernates in sheltered places, or in the soil; the eggs are laid in the spring, and there appears to be but one brood a year. Only a few forms have been bred; the larvæ of one of them is common on the house fly in autumn, and a similar form occurs on mosquitoes.

Our species are all practically congeneric,

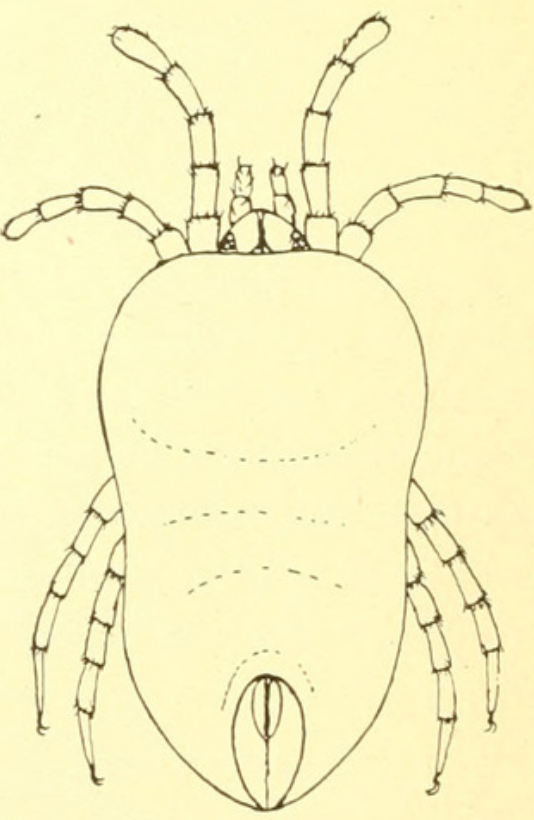

Fig. 49.-Trombidium LocUstarum MALE.

but those forms that have two claws at the tip of the palpi fall in the genus Microtrombidium Haller. Kolenati's genera Otonyssus and Peplonyssus, parasitic on bats, appear to be larval Trombidions. The genus Trombidium contains a great many species-in the United States about ten. Several of our species are very common, and are often seen 
crawling abuut in early spring, their bright red color and silky vestiture attracting the attention of even the most casual observer. In the Southwest there is a very large, hairy species, $T$. magnificum Le Conte; it appears at times in enormous numbers, and in parts of Arizona is called "angelitos" by the Mexicans. Most of the species are of good size, some among the largest of the mites. In the Tropics there is a group

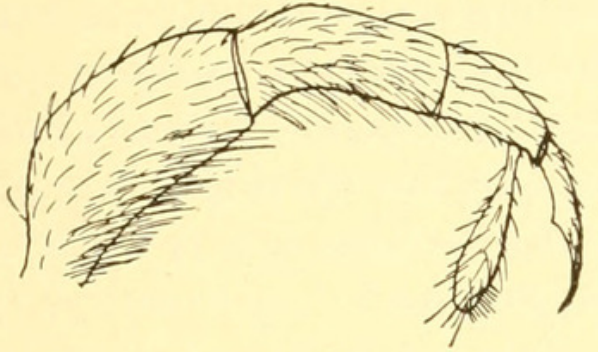

Fig. 50.-PALPUS OF TROMBIDIUM GIGANTEUM,

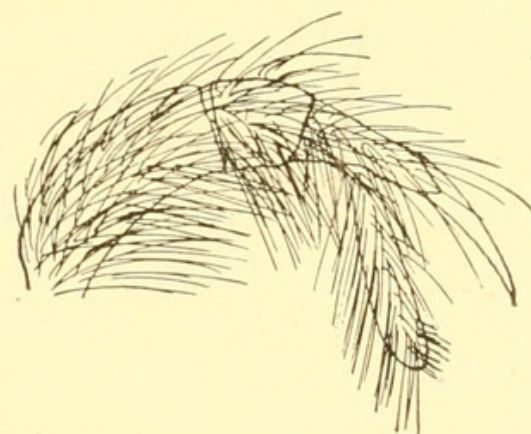

Fig. 51.-PALPUS OF TROMBIDIUM MAGNIFICUM.

of large species, of which $T$. tinctorium Linnæus is perhaps the best known; it attains a length of about one-half inch, and occurs in the warmer parts of Africa. It was supposed to be used as a dye in olden times, but does not seem to be so used now. One of our species, T. maritimum Banks, lives under stones between tide marks on the seasiore, and feeds sometimes on a maritime Coccid (Ripersia mari-

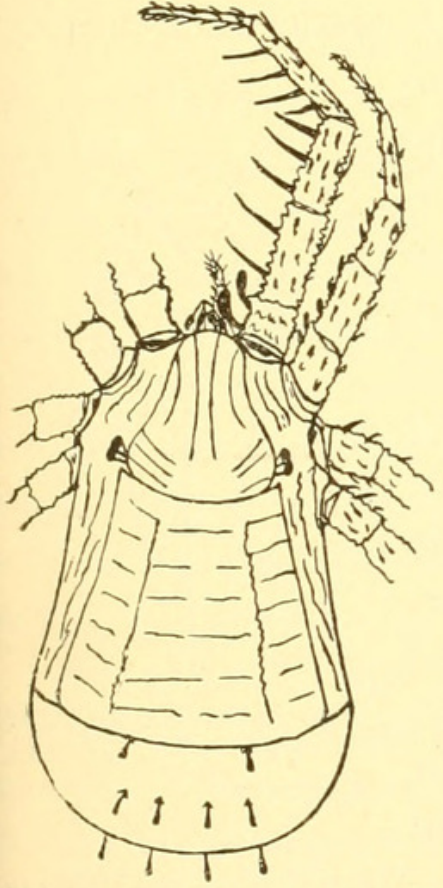

Fig. 52.-CECULUS AMERICANUS.

tima Cockerell). Our most common species in the Eastern States is T. sericeum Say; it occurs in moist woodlands, and feeds upon small insects, frequently upon springtails.

The genus Trombella is founded on a curious South American species, and Chyzeria represents a form from New Guinea which has projections along the sides of the body.

\section{Family CACULID E.}

A few mites of peculiar appearance, somewhat like Nothms of the Oribatidx, but structurally allied to Trombidium, constitute this family. They are rather large mites, of somewhat rectangular shape, and of a leathery texture, the legs are very rough, and the anterior pairs provided with a row of long spines. They terminate in two claws. The coxæ are arranged close together in a radiate fashion. The dorsum shows a transverse furrow, indicating the separation of cephalothorax and abdomen. The former is provided with a median shield, and from each posterior side arises

Proc. N. M. vol. xxviii-04-3 
a pedicel bearing two eyes similar to those of Trombidium. The abdomen is provided with two or more shields, according to the species. The ventral openings are very large and close together, each closed by flaps or valves. The mouth-parts are small and obscure, but the palpus is stout, five-jointed, the first and third joints very small, the penultimate ending in a curved spine, the last forming a "thumb." The mandibles are stout and terminate in a curved claw. They are concealed in the large conical rostrum. The species are brown in color. Very little is known regarding their habits and nothing as to life history. They occur in moss, anong fallen leaves, or in moist places. They move very slowly and feign death when disturbed. But one genus, Cxculus, is known. Several species occur sparingly in southern Europe and northern Africa. One, Cxculus americanus Banks, was discovered by Hubbard in southern California.

\section{Family HYDRACHNIDA.}

Since O. F. Müller described the Danish species in 1781, the water mites have attracted more attention and study than any other family of Acarina. A large number of important papers have been published,

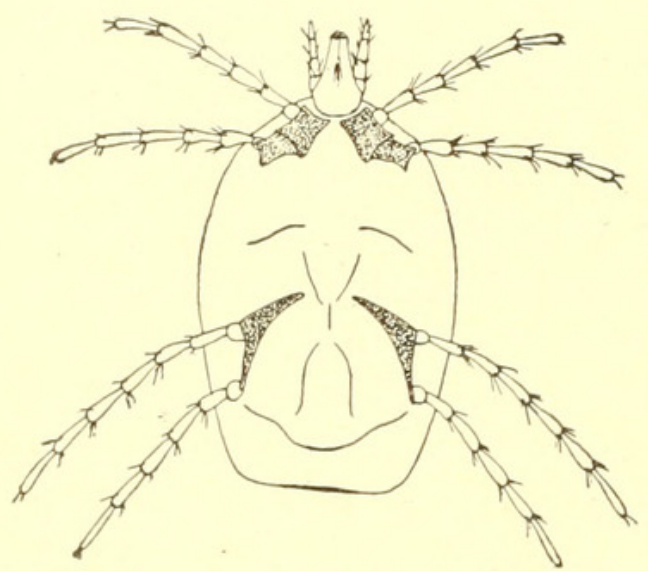

Fig. 53.-LimNochares; veNter. particularly on the European fauna, and a recent number of "Das Tierreich" (fascicule 13) is devoted to them. The body is commonly short, usually high, and sometimes nearly spherical. It is entire, there being no division into cephalothorax and abdomen. The legs arise close together on the anterior part of the venter, and often in a radiate arrangement. They have one or two simple eyes each side; in some cases these are situate close to the median line. The tegument is often soft, but sometimes provided with dorsal shields or covered with a pitted cuirass. The mouth parts are often hidden under the anterior margin of the cephalothorax. The beak (rostrum

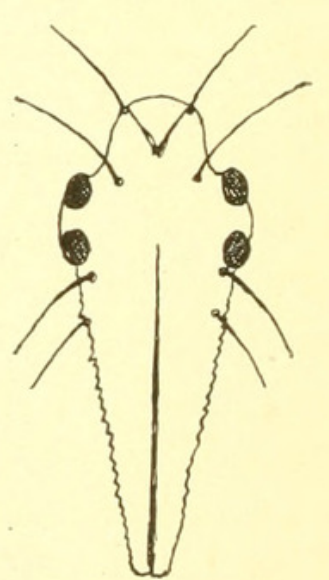

Fig. 54.-LIMNOCHARES; EYES AND DORSAL PLATE. or capitulum) is usually elongate pyriform, and the mandibles are twojointed, with a claw-like terminal joint; sometimes they are elongated into needle-like piercing organs. The palpi (maxillary) are of four or five joints, the basal one often very small, the apical one sometimes folding against the penultimate. The palpi vary greatly in shape and are of great value in classification. The legs are usually of seven 
joints, rather subequal in length, although the fourth pair is commonly the longest. The coxæ are often broad and entirely united to the venter and frequently to each other. The coxæ or epimera thus form coxal or epimeral platessometimes four, sometimes three, and in a few genera they are united into one plate. The tarsi often terminate broadly, and usually have two claws. They are provided with hairs and bristles. Sometimes there are rows of hairs for assistance in swimming; these are most numerous on the posterior legs. On the venter are the genital and anal openings;

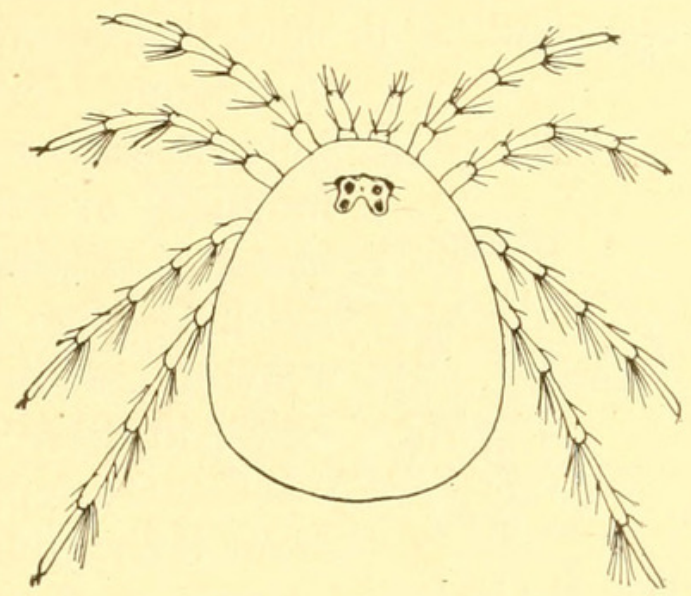

FIG. 55.-EyLAIS SP. sometimes the former is very far back, nearly or quite on the posterior margin. There is usually a group of sucking disks each side of the genital aperture, the number and position of which are quite characteristic of each species. On the dorsal side of the rostrum (capitulum) are two spiracles that lead to the tracher; in some forms there are no tracheæ.

The adult mite lives free in the water as a rule, but in Atax they are parasitic in the gills of mollusks. The young are frequently parasitic on insects or molOF EYLAIS.

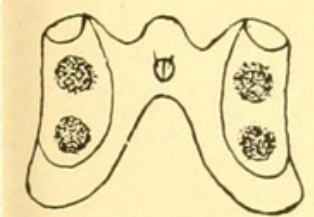

Fig. 56.-EYE-PLATE lusks. Many of the species are red or bluish-green in color; often they are prettily marked with yellow or black, and vary considerably in maculation. Hydrachnids are rather above the average size of mites, some species being fully 8 millimeters long and most of them over 1 millimeter.

There are frequently differences in structure between the sexes; in Arrenurus and some other genera the male has an elongated abdomen tipped with a median projection called the petiolus. In

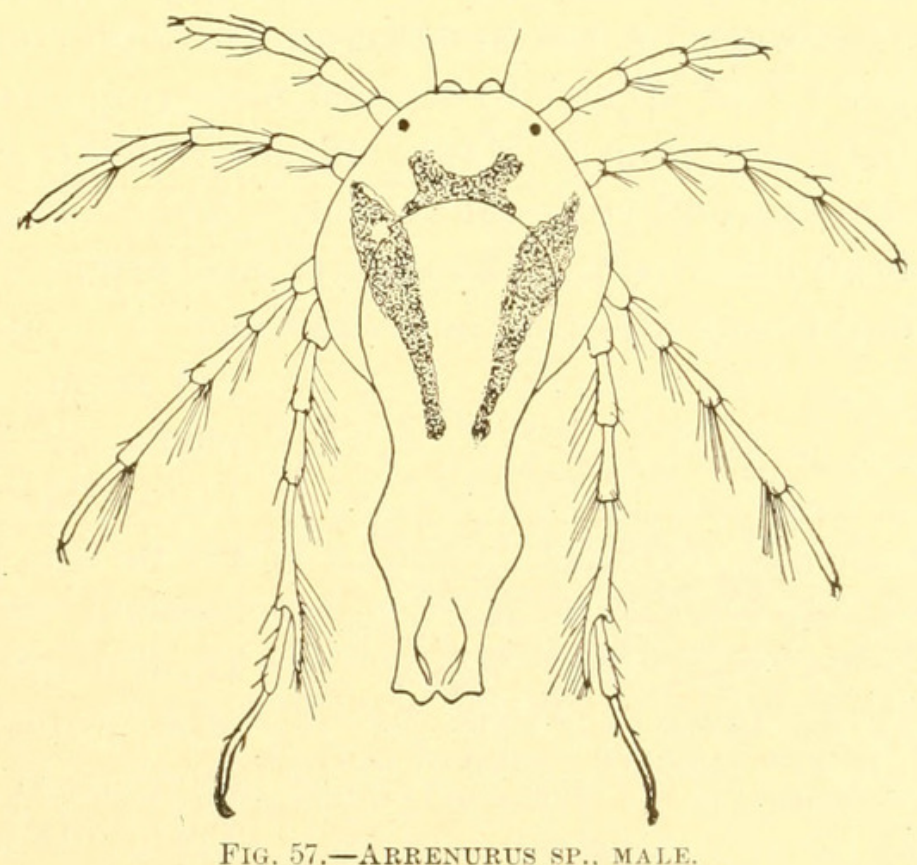
some forms the males have some of the joints of the legs especially modified. The female lays spherical eggs on water-plants, stones, or in the 
mantle-folds of Lamellibranch mollusks. During the course of development a membrane is separated from the embryo while yet inclosed in the egg-shell; the egg in this condition is the deutovum. After the egg-shell is broken the embryo continues to develop within this deutovum. The larva on hatching is six-legged, and

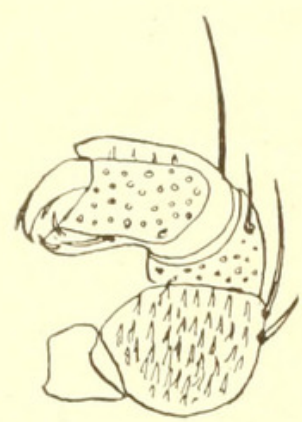

Fig. 58.-ARRENU RUS SP., PALPUS. in some cases is parasitic in the respiratory system of mollusks or attached to aquatic insects. Neumann has claimed that in one species of Limnesia the form hatching from the egg is eight-legged, and therefore a nymph, as in Pteroptus. Kramer has arranged the larve in three series, which he considers is the basis of classification. As a whole, the larve differ greatly from the adults and many were described as different creatures. Some were the basis of the genus Achlysia. The larva usually has very small mouth-parts; it fastens to an insect by means of hooks at the tip of the short, stout palpi, inserts its jaws and proceeds to feed. Gradually the body becomes swollen, the legs shrink, and the creature looks like an elliptıcal egg. The pupa is formed within this sac-like body, and from it in time issues the adult mite.

Nearly all Hydrachnida live in fresh water, a few forms occur in brackish water, and sereral are known from the littoral zone of the sea. They are sometimes parasitic, as already noticed, but usually free, and feed on any small animals they can catch, such as small crustacea, infusoria, and minute insect larvæ. The water mites are found throughout the globe, but appear to be most numerous in tem. perate regions. Many species inhabit rapid

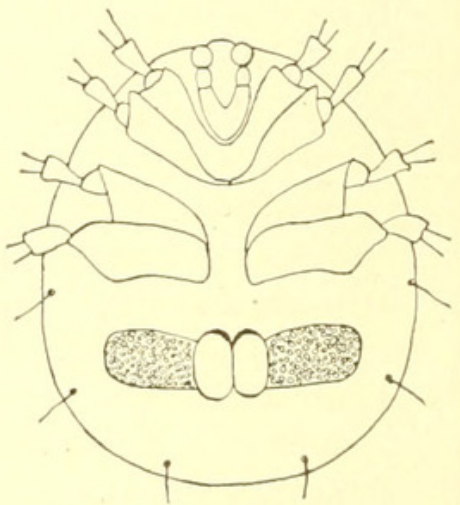

Fig. 59.-ArrenUrus SP., FEMALE FROM BELOW. streams and very cold water. About 60 genera and 600 species have been described. The species are often widely distributed and found amid very differing surroundings.

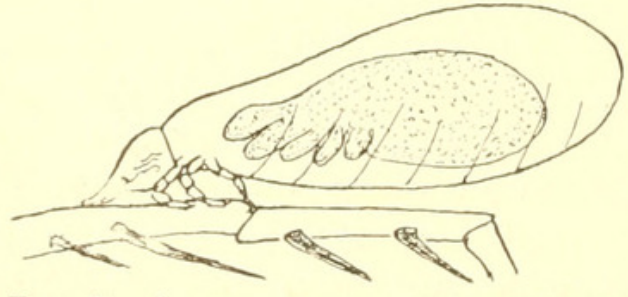

Fig. 60.-LARVA OF AN HYDRACHNA AT TACHED TO LEG OF AN INSECT; NYMPH INSIDE.

Various classifications have been made, one of which arranges them in 14 families. However, it may be better in this paper to use a less complex system. Some writer's have kept the Hydrachnidæ quite distinct from all other mites, but they are now generally recognized to be closely related to the Trombidiidæ. Nordenskiold believes the family to have two separate origins, and therefore not natural.

In the following table are found several common European genera which are not yet recognized from this country, and doubtless other 
European genera will also be found to occur in North America. A German, Doctor Koenike, published a valuable paper on some Canadian forms, and lately Dr. R. H. Wolcott, of Nebraska, has issued several excellent articles on our native species.

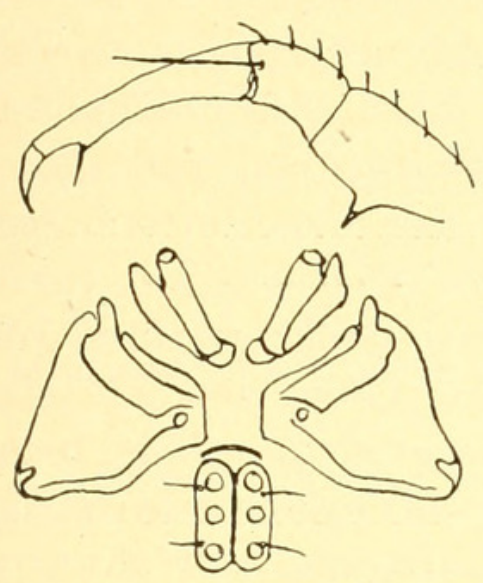

Fig. 61.-LimNesia SP., PALPUS AND COXAL PLATES.

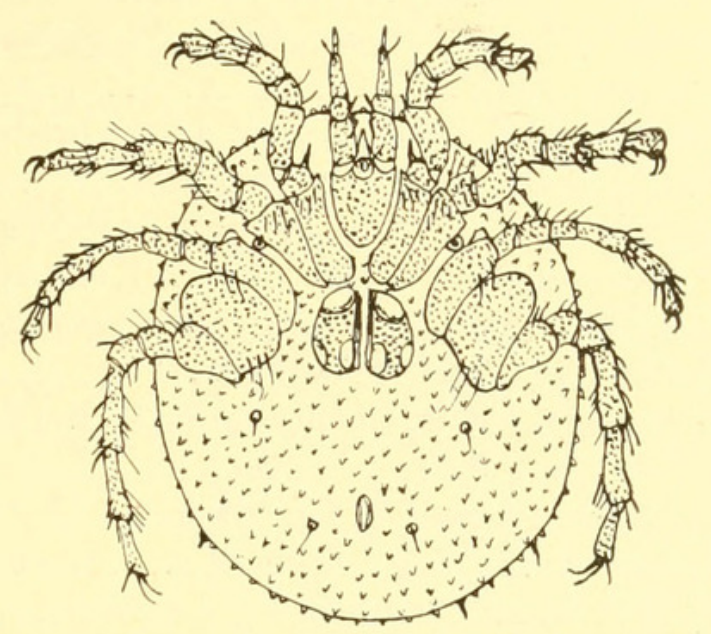

Fig. 62.-TYRELLia CIRCULARIS.

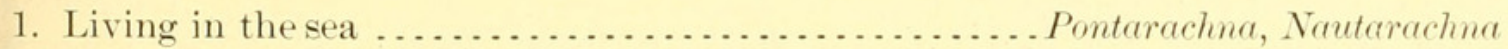

Living in fresh water . . . . . . . . . . . . . . . . . . . . . . . . 2

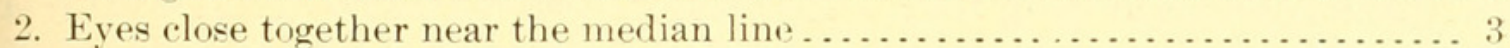

Eyes widely separate on the sides . . . . . . . . . . . . . . . . . . 4

3. Hind legs far from frent legs, and without swimming hairs; tips of tarsi obliquely truncate; body somewhat divided into cephalothorax and abdomen; in fact, the whole creature is trombidiform ........... (Limnocharine) Limnochares Hind legs not far from front legs, with swimming hairs; tarsi pointer; no indication of division of body .......................... Eylainæ) Eylais

4. Penultimate joint of palpus prolonged beyond base of last or with a tooth or spine-like projection near, or at tip................... Hydrachninæ) 5

Penultimate joint of palpus not prolonged beyond base of last, nor ending in a

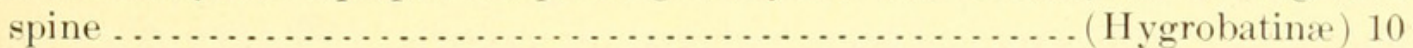

5. Mandibles, one-jointed, needle-like ....................... Hydrachna Mandibles of two joints, with claw at end . . . . . . . . . . . . . . 6

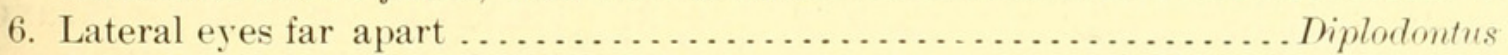

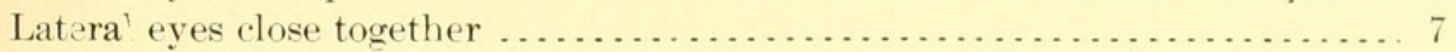

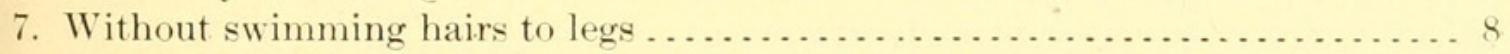

With swimming hairs. . . . . . . . . . . . . . . . .

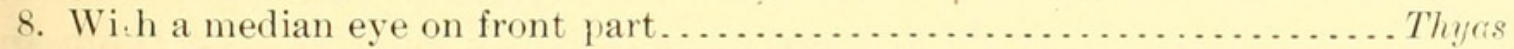

Without median eye . . . . . . . . . . . . . . . . . . . . . . . . . . .

9. With a median eye on front part ........................ Hydruphtes

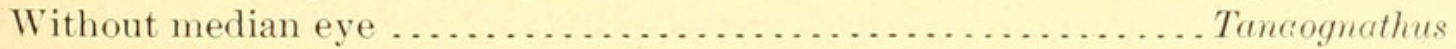

10. Fifth joint of palpus forming a claw opposable to the apical part of the fourth joint; males frequently have the abdomen extended behind . . . . . . . . 11

Fifth joint of palpus not forming a claw opposable to the apical part of fourth

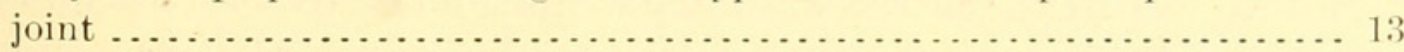

11. Capitulum or rostrum elongate, of two joints; palpi very small ..... Krendoriskia Capitulum short, entire . . . . . . . . . . . . . . . . . . . . . 12

12. Dorsum with a furrow, following somewhat the outline of body; in male open

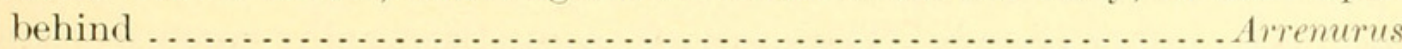

Dorsum without furrow . . . . . . . . . . . . . . . . . . . . . . . . . . . . . .

13. Epimera of both sexcs united into one plate $\ldots \ldots \ldots \ldots \ldots \ldots \ldots \ldots \ldots \ldots . . . . .14$

Epimera (at least of female) not united into one plate $\ldots \ldots \ldots \ldots \ldots \ldots . .17$ 
14. Fourth joint of palpus with a projection below $\ldots \ldots \ldots \ldots \ldots . . . .$. Xystcmotus

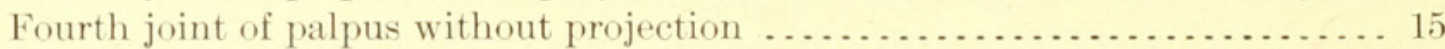

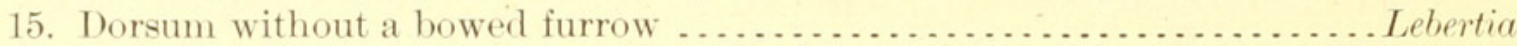

Dorsum with a bowed furrow . . . . . . . . . . . . . . . . . . . . . . 16

16. Second joint of palpus with a projection below; genital aperture at tip of

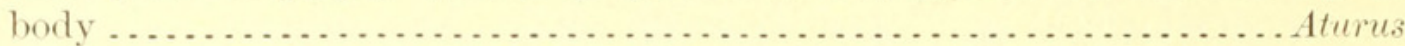

Second joint of palpus without projection; genital aperture much before tip of

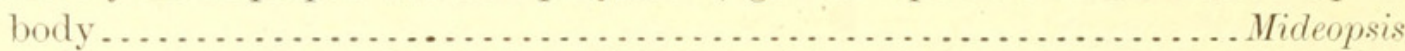

17. Fourth tarsus without claw; a long bristle at tip ................. Limnesia

Fourth tarsus with claw as others. . . . . . . . . . . . . . . . . . . . . 18

18. Genital opening with lip each side nearly covering the disks; palpi with spine

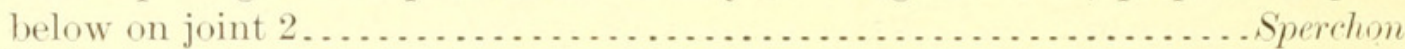

Disks near genital opening fully exposed . . . . . . . . . . . . . . . . . . . 19

19. Epimera of female in two groups . . . . . . . . . . . . . . . . . . . Kanikea

Epimera of female in three groups; genital opening usually with three disks each

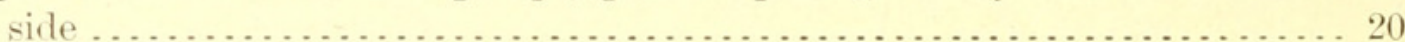

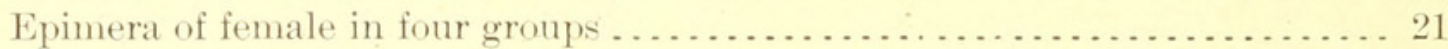

20. Apical joints of $\operatorname{leg} I$ normal . . . . . . . . . . . . . . . . . . . . . Hygrobates

Fifth and sixth joints of leg I curved . . . . . . . . . . . . . . . . . Atractides

21. Genital opening with three disks each side.................... Tyrrellia

Genital opening with more than three disks each side . . . . . . . . . . . 22

22 . Legs I and II with spirally ringed bristles. . . . . . . . . . . . . Neumamir

Legs without such bristles. . . . . . . . . . . . . . . . . . . . . . . 23

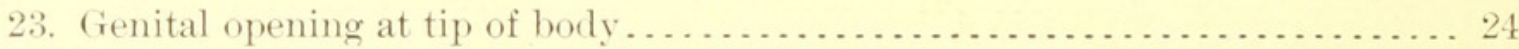

Genital opening much before the tip . . . . . . . . . . . . . . . . . . . 25

24. Without swimming hairs on legs; fourth joint of palpus without three spurs below; genital area large . . . . . . . . . . . . . . . . . . . . . . . . . . .

With a few swimming hairs; fourth joint of palpus with three spurs, or papillæe, below; genital area smaller . . . . . . . . . . . . . . . . . . . . . . . .

25. Hind epimera with a pointed projection below; palpi larger than leg I. . Najadicola

Hind epimera without a projection; palpi smaller, and end in two or three small claws; the fourth joint has two papillæ below . . . . . . . . . . . . Piona

The genus Limnochares is practically an aquatic Trombidian; the body is of the same shape, and red in color. It can not swim, but

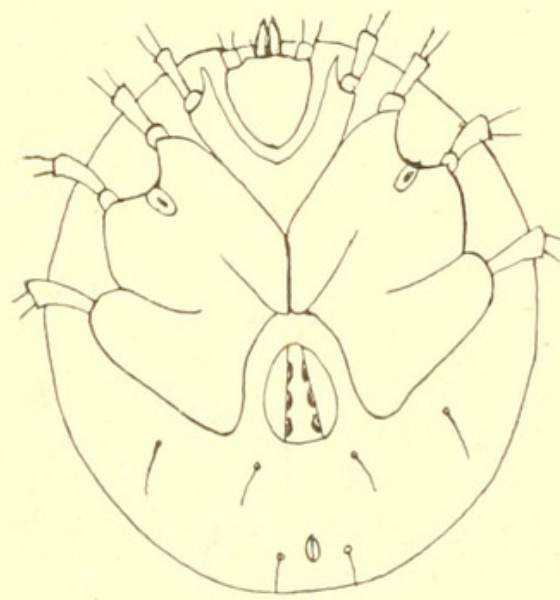

Fig. 63.-VENTER OF LEBERTiA. creeps over the mud and plants under water. The young are parasitic on water-skaters (Gerridæ). Our species is very like the European.

We have three species of Eylais. They are distinguished by having four simple eyes situate close together on a plate near the median line. They are most frequently found in ponds. A larva of this genus has been found on mosquitoes. The genus Thyas, of which we have a few species, has no swimming hairs on the legs, and beside the lateral eyes there is a median eye in front. Several species of Arrenurus have been described from North America, and doubtless many more occur. They are often green in color, and have a chitinous dorsum. The dorsum has a circular furrow in the male open behind. 
The males have the body extended behind, and there is a small median petiolus. They live most commonly in lakes and ponds. Krendorskia and Steganaspis are each represented by one species.

In Aturus the epimeral plate covers nearly the entire ventral surface; one species is known from a small river in Canada. Of Xystonotus and Mideopsis but one species is known in each; the latter is also a common European water-mite.

The species of sperchon are often found in cold and rapid mountain streams. Three species are known from Canada. They have the palpi enlarged at base, and the second joint bears a strong spur below. The sucking disks each side of the genital opening are nearly concealed by lateral flaps. The legs have no special swimming hairs.

Limnesia is a large genus; three species have been recorded from Canada, two of them European. They have a soft body; the hind legs are

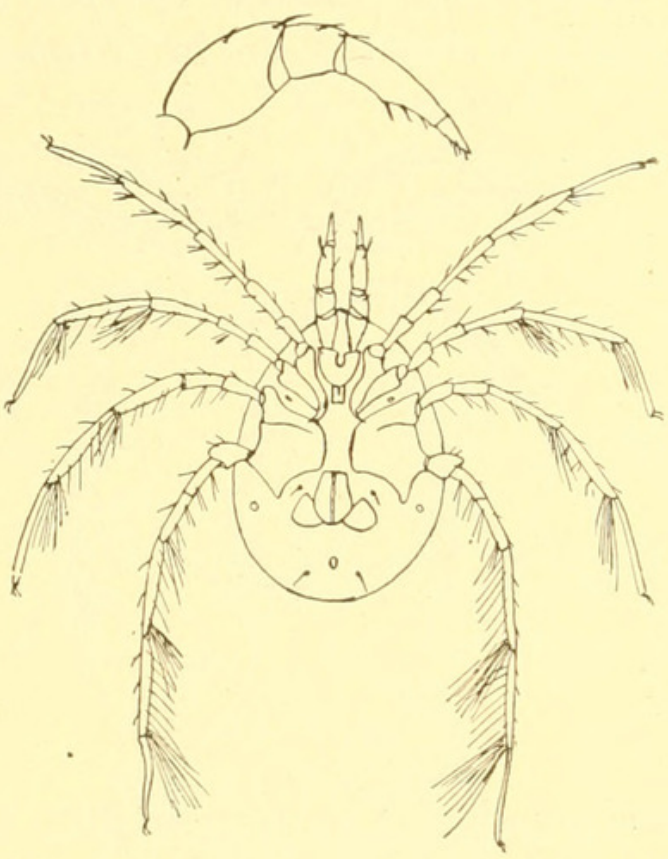

FIG. 64.-PIONA SP., AND PALPUS ABOYE. well provided with swimming hairs, and the fourth tarsus lacks the claws, but is provided with a bristle at tip. The palpi have the basal joints enlarged and often with a spur below. They usually occur in lakes.

Koenikea is represented by one species widely distributed in the

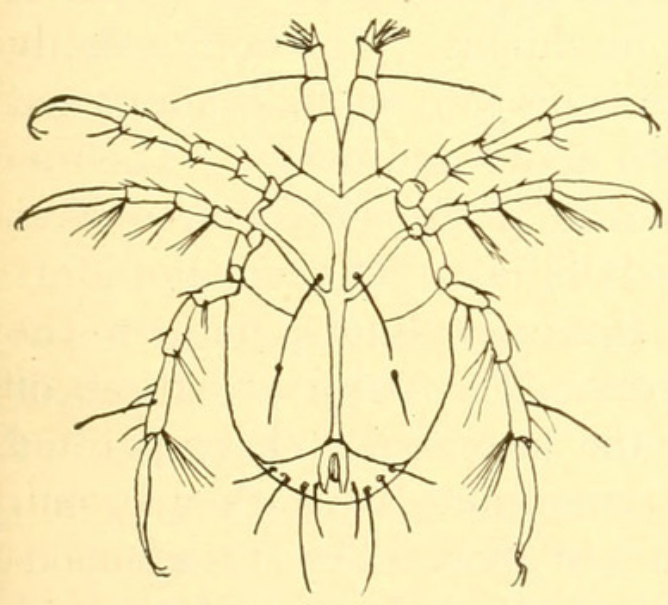

FIG. 65.-LARVA OF PIONA. northern parts of our country. The species of Mygrobates have soft bodies, the slender legs destitute of trueswimming hairs, and the palpi have a spur or tooth below. There are three sucking disks each side of the genital orifice. Four species are known from Canada.

Atax is one of the largest genera, and Doctor Wolcott has worked out some twelve species, and another has since been added from Texas. The genital opening is situate at the tip of body, and the sucking disks each side are ten or more in number. The legs have swimming hairs and the first pair is thicker than usual. The palpi are enlarged at base, and the fourth joint bears three papillæ or spurs below. Most of the species occur, for at least a time, in certain fresh-water mussels, particularly of the genera Unio and Anodonta. 
They are found on the mantle-folds or gills of the mussel, and feed on the minute animals drawn in by the mussel. The late Doctor Haldeman described a number of species under the generic name of Unionicola.

The genus Neumannia is closely allied to Atax, but peculiar on account of the spirally ringed bristles on legs I and II.

The genus Piona (Curvipes) is also a large genus, and about 19 species are now known in North America. They occur chiefly in lakes

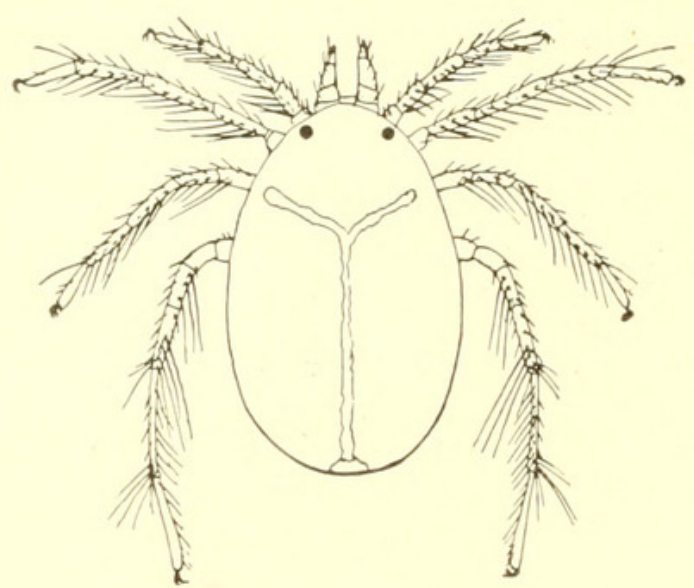

FIG, 66.-ATAX sP.

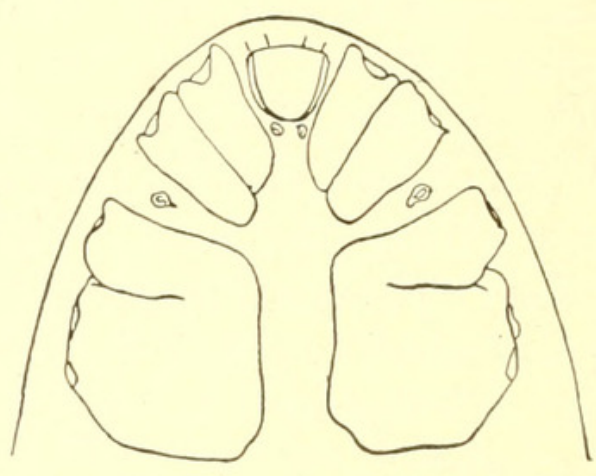

Fig, 67,-COXal plates of atax.

and ponds. The fourth joint of the palpus usually has two papillæ beneath, and the legs are well provided with swimming hairs. The genital aperture is much in front of the hind margin, and each side of it are a great number of sucking disks, often of two sizes.

\section{Family HALACARIDA.}

This is a small family of marine mites. They have a leathery skin, frequently granulate or striate, but commonly destitute of bristles. Sometimes there are coriaceous plates or shields. The body usually

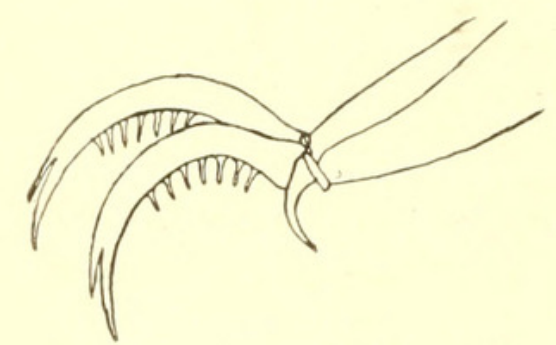

Fig. CS.-CLAWS OF HALACARUS. shows the division into cephalothorax and abdomen, both above and below. The rostrum is often quite prominent, sometimes as largeas in the Bdellidæ. The cephalothorax usually has three eye-spots, one on the middle in front. The palpi are three or four-jointed, the last article sharp-pointed at tip. The mandibles are rather prominent, and end in a single straight, or recurved claw. The legs are moderately long, rather widely separate at base, lateral or sub-lateral in origin, and end in two claws. They bear a few scattered bristles. The genital opening is quite large and far back; the anus is small and at the tip of abdomen. These mites have no tracheæ, but do not appear to be related to other atracheate Acarians, but rather to the Bdellidæ and Oribatidæ. It is, perhaps, not a natural family, but derived from several groups. The Halacaridæ are found crawling slowly over algæ, 
frequently in shallow water, but some have been dredged at considerable depths. The adults are free, and feed on diatoms and other minute vegetation. The young of some forms feed on the eggs of Copeopods, while others are attached to various animals. One is known to occur on a Chiton. They are from one to two millimeters in length, and their colors depend largely on the nature of their food. The young have the general appearance of the adults, and nymphs sometimes possess rudimentary genital organs. The legs of the nymphs have each one less joint than in the adults. They have been

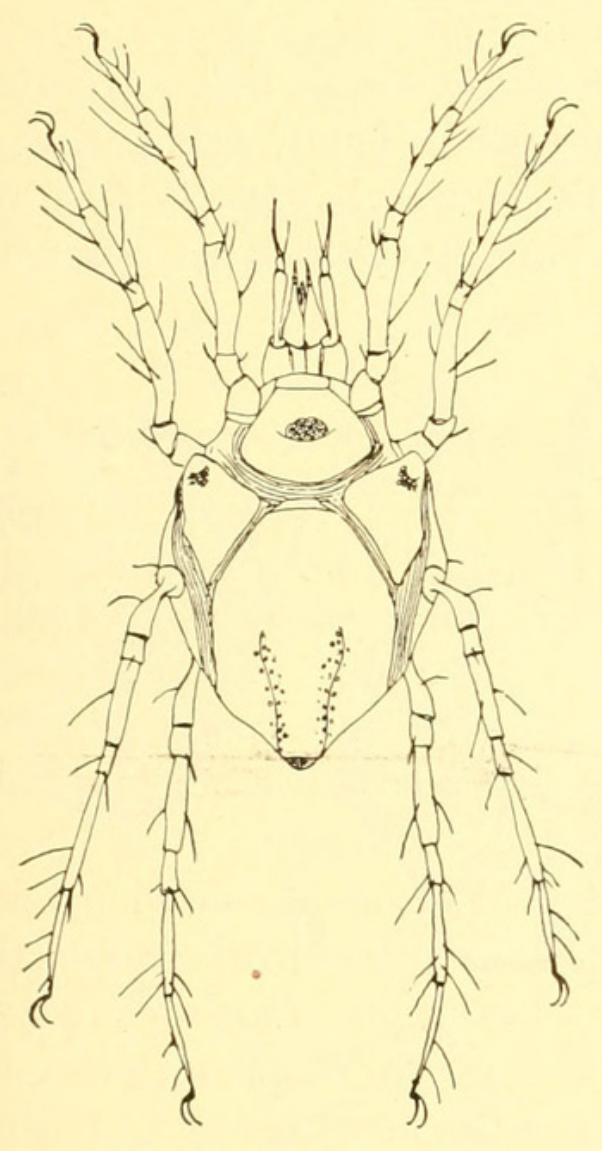

Fig. 69.-HALACARUS SP.

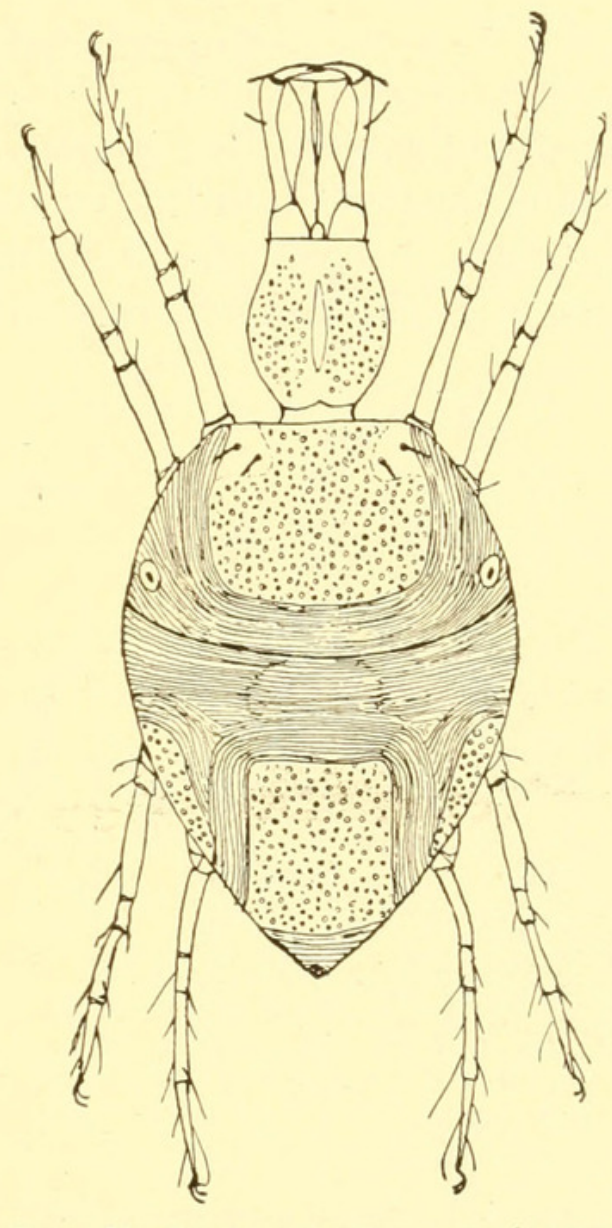

Fig. 70.-SCAPTOGNATHUS SP. (AFTER TROUESSART).

found in nearly all seas, and about seventy speries are now known. The forms along the coasts of North America have not been studied. The principal genera may be tabulated, as below.

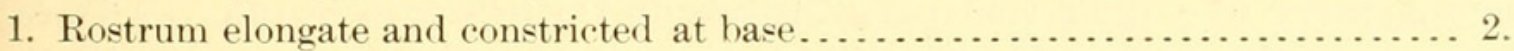
Rostrum not constricted at base ...................................

2. Palpi apparently three-jointed, separate................... Scaptognathus. Palpi, four-jointed, connate at base ......................... Trouessartella.

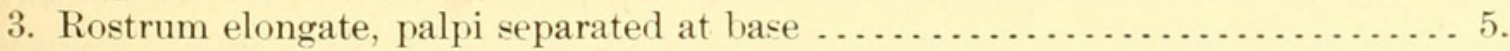

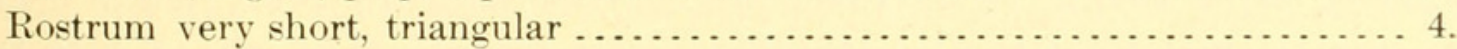

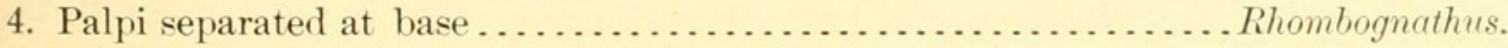
Palpi connate at base .................................... Simognathus.

5. Palpi apparently but three-jointed $\ldots \ldots \ldots \ldots \ldots \ldots \ldots \ldots \ldots \ldots \ldots \ldots \ldots$ Coloboceras.

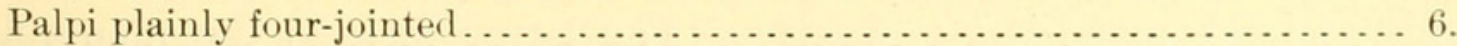

6. Third joint of palpus nearly as long as fourth ........................ Agaue. Third joint of palpus much shorter than fourth 
Most of the species come from the French coasts or the Atlantic Ocean; one was described from fresh water. A few are from other regions, and doubtless, as they aremore collected, the family will be of considerable size. Malacarus, the largest genus, contains about fifty species, several of which bear some resemblance to Scutovertex in the Oribatidæ. Most of them are marked with brown, reddish, or black. Dr. E. Trouessart, of Paris, has published very largely upon them. Packard described, under the name of Thalassarachna verrilli, a species of Halacams from the coast of Maine; it was found on algæ.

\section{Superfamily IXODOIDEA.}

The members of this group, commonly known as ticks, are of all Acarians the most familiar to ordinary people. Their body is covered by a tough, leathery skin, which in the female is capable of great extension. The ticks (before distention) are of a somewhat triangular

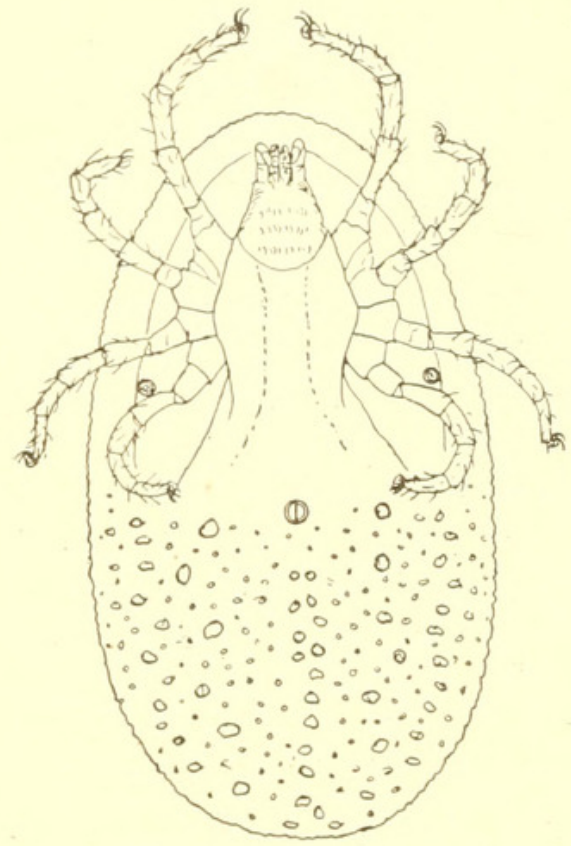

Fig. 71.-ARGAS MINIATUS, FroM BELOW.

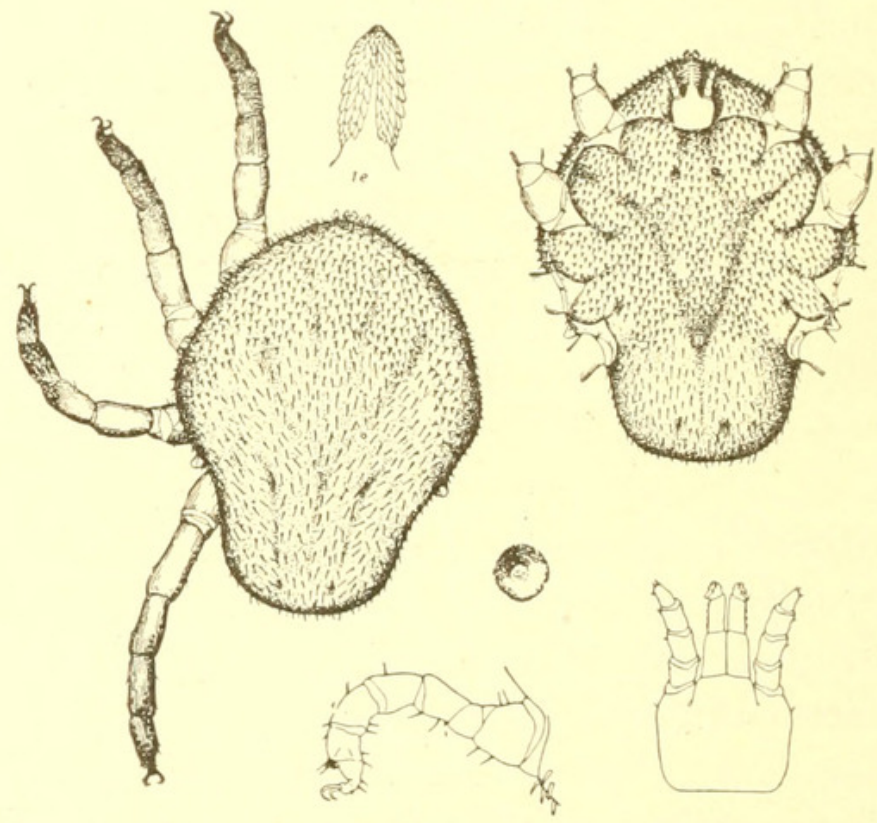

Fig. 72.-ORNITHODOROS MEGNINI; NYMPHAL FORM, AND DETAILS (Marx).

outline, moderately flat, with prominent, slender legs and a beak-like rostrum in front. On the anterior part of the dorsum there is a corneous piece or shield that may represent the cephalothorax. This is known as the scutum, and is absent in the family Argasidæ. With the male this scutum covers the greater part of the dorsum. Articulated to the anterior margin of the scutum, usually within an emargination, is a small, transverse piece, the capitulum or head. The posterior corners of the capitulum project backward in spines. In the female ticks there are on the dorsum of the capitulum two pitted areas, known as the porose areas. The capitulum bears the palpi on each side and the mandibular sheaths. The latter include the mandibles 
and the hypostome. These are sometimes called the proboscis, haustellum, or rostrum. The hypostome is a central piece, bearing many recurved teeth or denticles. The number of rows of these denticles is used as a specific character in classification. At the tips of the mandibles are two or three processes known as the apophyses. They also have been used in classification, but are variable. The palpi are always very short and stout and composed of four articles, not, however, very distinctly. Some species have eyes situate one at each lateral angle of the scutum. The posterior margin of the body, especially of the male, is usually somewhat lobate, these lobes being known as the posterior marginal festoons. The stigmata or spiracles are above and usually behind the coxæ IV. Each is surrounded by a reticulated or pitted plate of varying outline, and called the peritreme or stigmal plate. It is often of large size. Upon the venter there are several furrows characteristic in position and of value in classification. The anal opening is a small, circular hole some distance behind the coxæ IV; the genital pore is situate on the front of the sternal area, slightly behind the mouth-orifice. The legs arise close together, but in the distended females the coxæ become quite widely separated. There are six joints in the leg-coxa, trochanter, femur, tibia, protarsus or metatarsus, and tarsus; the latter is sometimes divided, while the femur often presents a basal distinct portion, which may be the

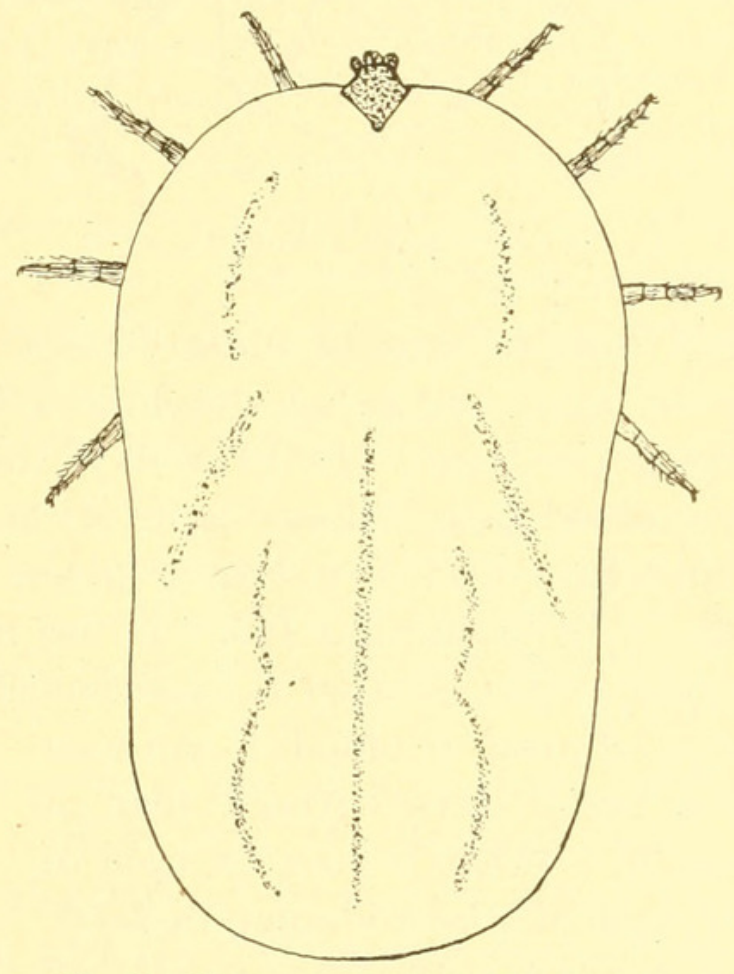

Fig. 73.-Boophilus andulatus, Female. trocbantin. Upon the tarsus of the first pair of legs is a depressed circular area, supposed to be an organ of hearing; it is known as Haller's organ, in honor of its discoverer. The tarsus terminates in a short stalk that bears the two claws and the pulvillus or caruncle. The body of a tick is usually dull colored, but some forms are mottled with brown and yellowish or reddish.

Ticks are parasitic on mammals, birds, and reptiles. But at times they may leave their host, and are not confined to one host, althougin some species show a preference: Most of them do but little damage to their hosts while sucking blood, but several closely allied species belonging to the genus Boophilus transmit an organism, the Pyrosoma bigemminum, that causus a disease in cattle known as Texas fever, Southern cattle fever, red-water, heart-water, etc. As a result of her bloodthirsty naturo the female tick becomes enormously distended, 
and is then in a mature condition. The life history of ticks has been described by Curtis, Morgan, Lounsbury, and others. Tieks pair during parasitism, the male remaining beneath the female for some days, the latter finally dropping to the ground to deposit her eggs. These may be as many as 10,000 to 20,000 , and issue as elongate masses in front of the tick. During the operation the head is with-

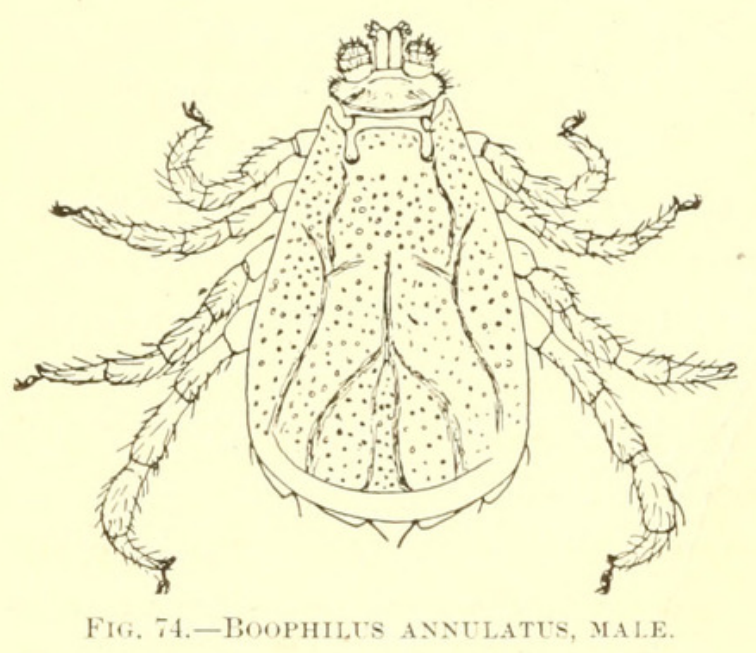
drawn into the body, so that the neck behind the capitulum is close to the genital pore. As the eggs issue they are coated with a viscous substance secreted from glands in the neck. These eggs lay upon the surface of the soil, or just beneath it, and the larvæ hatch in a few days. The young ticks, known as "seed ticks," ascend the nearest support of grass or herb, and patiently await the coming of some animal. Delay and disappointment must often end in starvation and death. However, many secure an attachment to some animal, often, perhaps, not the desired one. In a few days the young tick is rapidly distended by the blood it has sucked from its host, and drops to the ground. Here it seeks a cavity or hiding place, and rests. In three or four days the skin splits and from it the nymph issues, and begins the same waiting process that it experienced as a larva. As it has already had a good meal of blood, it can wait for many days without fear of death. When it secures hold of an animal, the abdomen distends as before, and it soon falls off again to hide and molt. After this molt the tick is adult; it waits again for a host, and when secured starts the life-cycle anew. The Texas cattle-tick and its allies do not drop off for molting, lut cast the skin while upon the host.

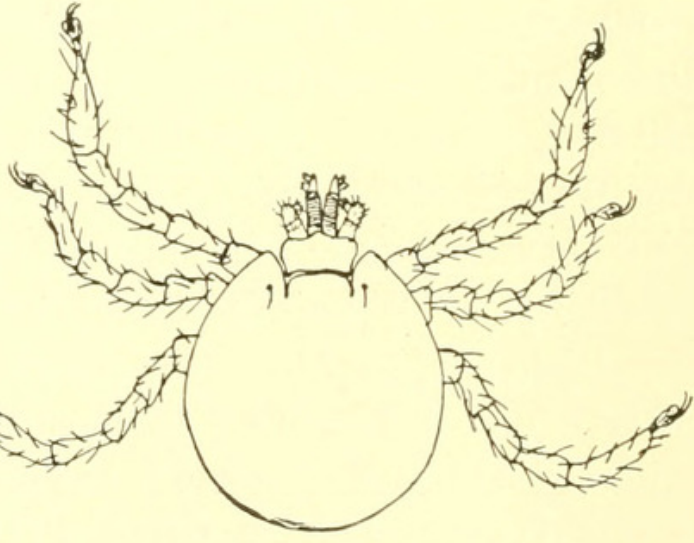

Fig. 75.-LARVA OF BOOPHILUS ANNULATUS. They drop to the ground, however, for the purpose of laying eggs, as the other ticks.

In the true ticks there is a considerable difference in the abdomen of males and females. In the latter the dorsal shield does not cover the entire abdomen, while in the male this shield extends to the tip. The males of some species have spines upon some of the coxæ, and sometimes an extra pair of shields on the venter. 
The internal anatomy of the Ixodidæ has been examined by Heller (1848) and later by Pagenstecher (1861). The pharynx soon contracts into a slender œosophagus, which, as usual, passes through the "brain" and into the stomach. The latter is not very large, but has several diverticula or cæca, some in front, and usually four large ones behind and one longer on each side. The color of the food in the cæca often shows through the integument, so that the same species at different times exhibits different markings on the body. Upon this basis the earlier authors often described one species under several names. The intestine is short and straight, enlarging somewhat before the anus. The breathing apertures or spiracles open into a large sac, which soon divides into a host of small tracheæ that spread out in the body cavity. In the anterior part of the body are two large, botryoidal salivary

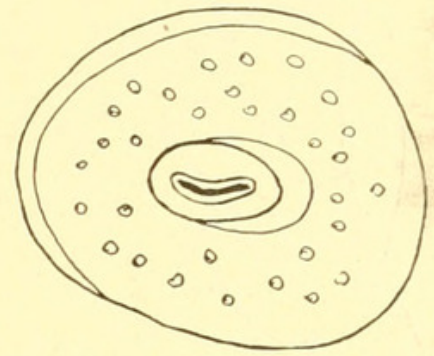

Fig. 76.-STigMAL PLATE OF BOOPHILUS ANNULATUS. glands, opening through a duct each side of the mouth. The female genital organs consist of two elongate ovaries, each with a slender oviduct, which unite shortly before the vulva. The male organs consist of the two slender testes, each emptying into a large median sac, from which a slender duct leads to the opening.

The Ixodoidea are readily divided into two families.

No scutum; no ventral shield; mouth-parts of adult not prominent from above; no pulvillus to tarsus in adults; stigmal plate between coxæ III and IV . . Argasida

Scutum present; sometimes ventral shields; mouth-parts of adult prominent from above; pulvillus to tarsus of both adults and young; stigmal plate behind coxæ IV.

Ixodida

The Argasidæ, containing but few genera, are in some ways intermediate between the true ticks (Ixodidx) and the Dermanyssidx. The skin is. usually covered with granulations or deeply pitted and the head and mouth-parts are hidden beneath the anterior part of the body. They are nocturnal in habit and feed on the blood of mammals (including man) and birds. Unlike the true ticks, the females of this family do not become so greatly distended with blood. There are two genera in our fauna.

Capitulum at least its length from the anterior margin .................. Argas Capitulum under a beak-like projection, close to anterior margin....... Ornithodoros

It is to the genus Argas that the famous Miana Bug of Persia belongs (A. persicus). It lives in houses, and its puncture was declared by the early travelers in those regions to produce startling results; consulsions, delirium, and even death following its attack. Specimens kept in Europe for experiment have failed to produce these dire consequences, but there is such a wealth of testimony as to the dangerous effect of the bite in Persia that possibly in that country the Miana Bug may at times carry the germs of some disease. The European 
species, Argas reflexus, commonly infests pigeons, but has been known to attack man, not however with serious results. Our species,

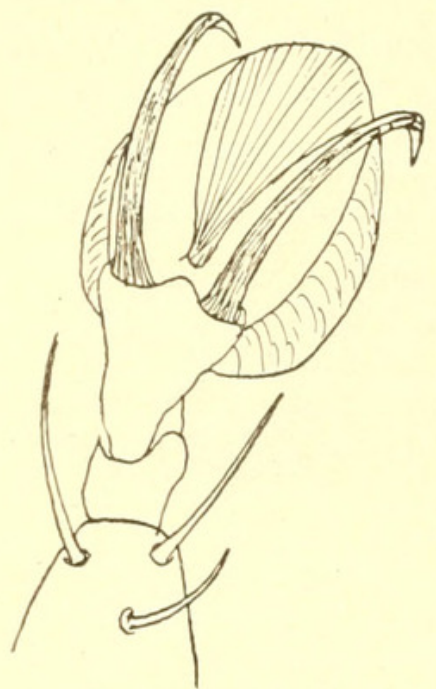

Fig, 77.-CLAWS OF BOOPHILUS ANNULATUS. the "chicken tick," Argas miniata Koch (americana Packard) is not uncommon in the southern parts of the United States from Texas to California, and often does a great deal of injury to poultry. Chickens, badly infested, droop, refuse to eat, in a few days drop down, and finally die. It is of a dull reddish color, and the body granulate. The eggs are laid in masses of 30 to 100 and deposited in cracks of the chicken house. Perhaps the best remedy is to spray the inside of the chicken house with kerosene or benzine, then whitewash or dust with carbolated lime, and finally daub the ends of the roosts with coal tar. Isolating the roosts, by suspending them on stout wire, or by placing a barrier of cottonwaste soaked in oil around each end, will also be helpful.

It is now claimed that the chicken-tick in Brazil transmits the bloodparasite of a disease fatal to fowls. A similar species (A. sancheai Dugès) is found in houses in New Mexico and Arizona and is there called the "adobe tick."

In the allied genus, Ornithodoros, we have two species, both known to attack man. O. turicata Dugès is the most dangerous. The Mexicans call it "turicata." In southern California they are known as "pajahuellos"

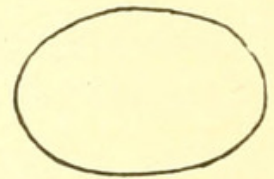

FIG. 78.-EGG OF BOOPHILUS ANNULATUS. to the cattle herders. Their bite will cause large swellings that remain for some days, and are very painful. The other species, O. megnini

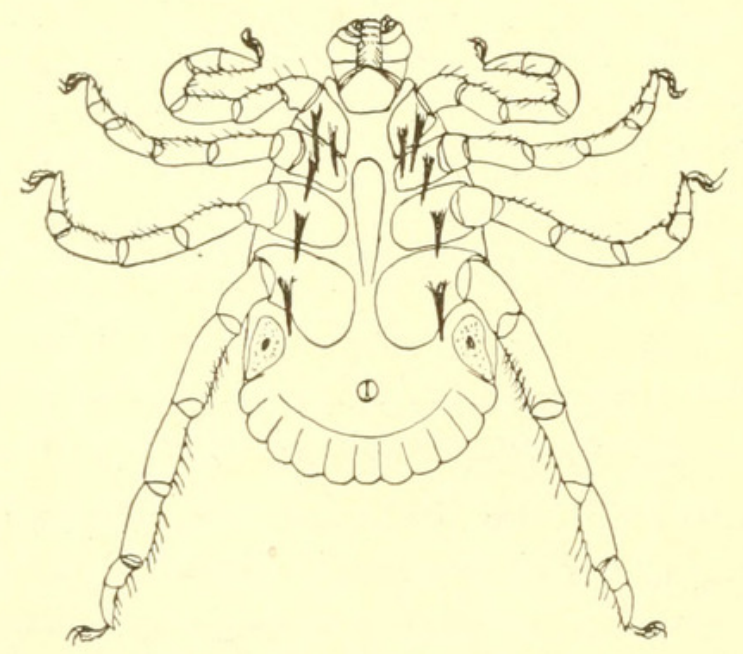

FIG. 79.-DERMACENTOR VARIABILIS, MALE FroM BELOW. Dugès, is a serious pest to cattle and of much more common occurrence. It infests the ear's of horses, cattle, sheep, and sometimes man, and has been called the "spinose ear tick." The nymphal stage is quite unlike the adult tick and was figured by Marx as Rhynchoprion spinosum. It is of a brown or blackish color, and in the nymphal stage is clothed with many stout spines. It has been known to cause death in cattle.

They can usually be removed by an application of linseed or olive oil. Like the preceding it is a Mexican species, which occurs only in the southern parts of our country, but is sometimes found as far north as Nebraska. The adult is known to Mexicans as the "garrapata," and the young are called "pinolias." 
The Moubata bug, O. savignii, is an African species whose puncture is reported to produce effects almost as dangerous as those ascribed to the Miana bug. It attacks both man and beast, sometimes occurring in houses. The pain of the puncture is not felt until several hours after it is inflicted, but gradually the spot becomes inflamed and irritable.

The Ixodidæ, or true ticks, are represented by a large number of species in tropical countries, but in the temperate regions they are much less common. However, there are about twenty-five species in the United States, and one of these, the Texas cattle tick, is a pest of prime importance. Our ticks are ar-

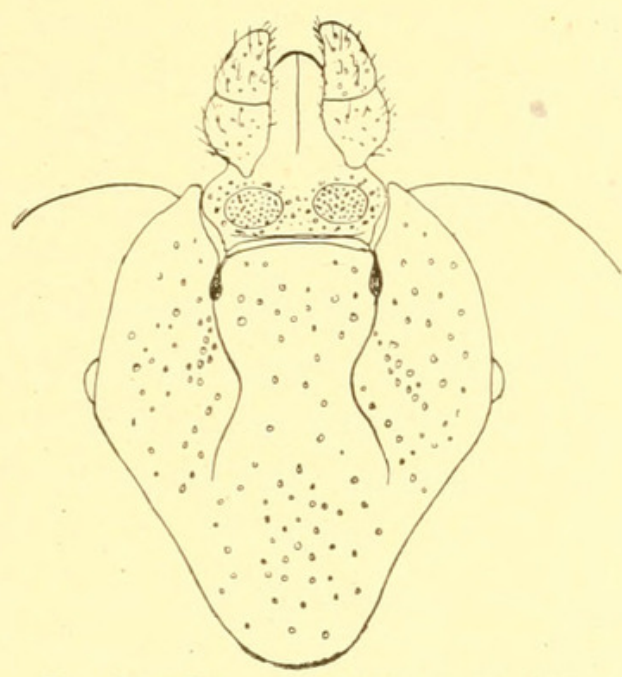

Fig. 80.-DERMACENTOR VARIABILIS, SHIELD OF FEMAI.E. ranged in about seven genera, which may be tabulated as follows:

1. Palpi short, not or only slightly longer than broad; capitulum short . . . . . . 2 Palpi plainly longer than broad; capitulum longer . . . . . . . . . . . . . . . 5

2. Dorsal surface of capitulum hexagonal, the sides projecting in angles; male with

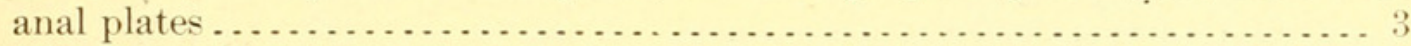

Dorsal surface of capitulum rectangular, sides straight; male without anal plates. 4

3. Second and third palpal joints extend laterally into sharp points; stigmata nearly circular.

Boophilus

Second and third palpal joints even; stigmata comma-shaped ...... Rhipicephalus

4. Eyes present; external border of palpi straight; coxæ I bidentate.... Dermacentor Eyes absent; external border of palpi uneven; coxæ I not bidentate. Hrmaphysalis

5. Anal groove surrounds anus anteriorly and opens posteriorly; eyes absent; stigmal

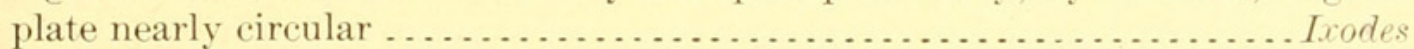

Anal groove surrounds anus posteriorly and opens anteriorly; eyes present; stig-

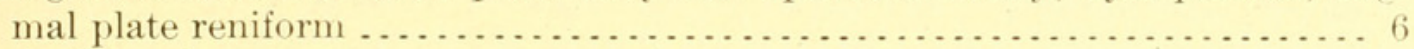

6. Anal plates absent.

Anal plates present in male.

Amblyomma

Our one species of Boophilus (B. annulatus Say) (bovis Riley) is the distributer of Texas fever, a disease of cattle that causes enormous losses in the South, particularly in cattle imported there from the North. The southern cattle tick is found only in the Southern States and the Government maintains a quarantine line where cattle brought North may be cleansed of their ticks. The female tick is of a dark, dull brown color, with reddish scutum and legs; the male is reddish brown, the legs paler at articulations. The cause of Texas fever is a minute Protozoan parasite, Pyrosoma bigemminum. This is taken up with the blood by the Boophilus, which then inoculates each animal that it attacks. And even the young that have not infested any animal may produce the disease. The young ticks, called "seed ticks," are born on the ground; they climb upon grasses or bushes, and await the coming of cattle. Each attaches itself at the first opportunity, and begins to draw blood. In about a week it molts, remaining on the 
host during this period. The male increases but little in size, but the female becomes enormously swollen and in about a month she is ready

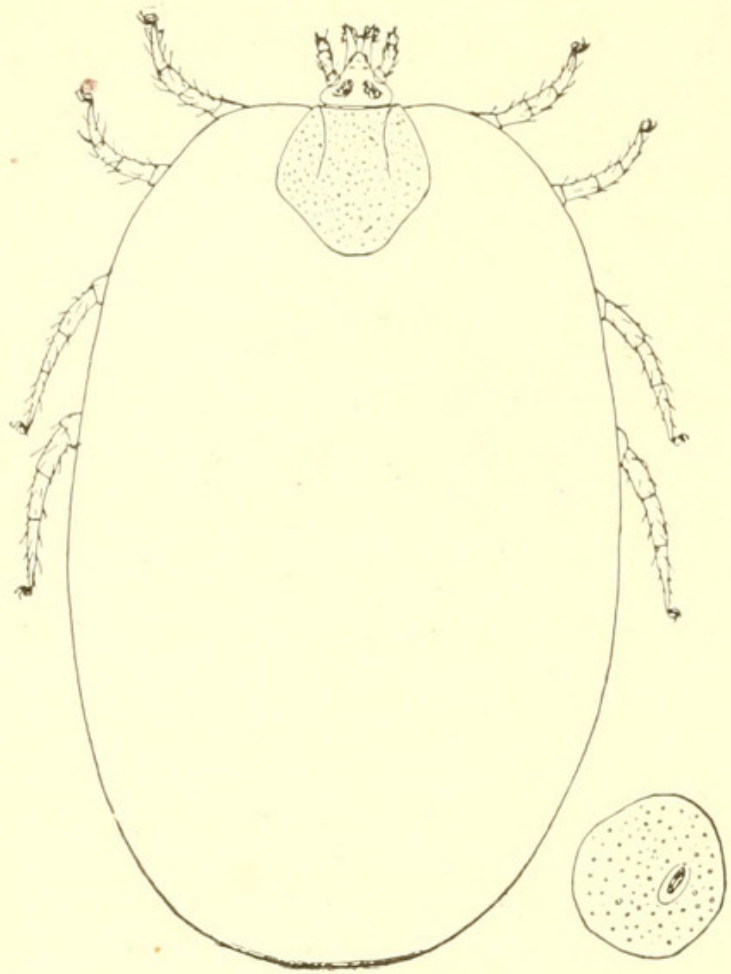

FIG. 81.-IXODES CRUCIARIUS, FEMALE, AND STIGMAL PLATE. to drop off and deposit eggs.

Once in the blood of cattle the parasite destroys the red blood corpuscles, and causes a thinness of blood, the hæmaglobin of which appears in the urine. After death the spleen and liver are found to bs greatly enlarged. The most promising preventive seems to be the removal of cattle from pasture for one year. This pasture disinfection may be hastened by cultivation for one year, or grazing it to sheep. It has been noticed that southern cattle may become immune, and with this hint a method of vaccination was devised for treating northern cattle when taken South.

There are several other species of ticks often found on cattle, but none are known to carry the parasite of Texas fever.

Of Dermacentor there are three or four species in this country, all with the scutum more ov less variegated with white and brown. The most common one is the "dog tick," Dermacentor variabilis Say, and is our most widely distributed species. It is found on cattle, dogs, horses, rabbits, and sometimes on man. On the latter it causes no serious consequences, but is a source of much irritation. They are so tightly attached that it is often impossible to remove them without either leaving the head in the flesh or else tearing out a piece of the skin. The other species are similar to the dog tick, but are less common. One occurs on the moose, and others on cattle, deer, and sheep.

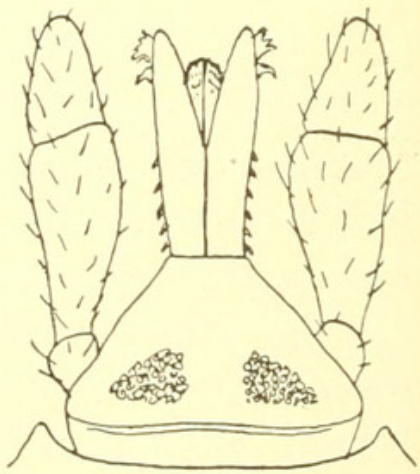

FIG. 82.-HEAD OF IXODES.

D. reticulatus Linnæus, a European species, is perhaps more frequent in California than D. variabilis.

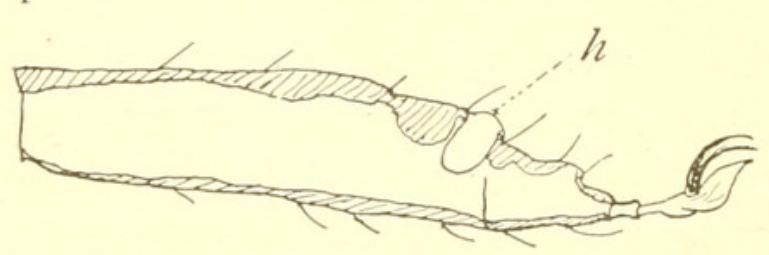

FIG. 83.-LEG I OF IXODES; SECTION THROUGH TARSUS, $h$ HALLER'S ORGAN.

In the genus Hamaphysalis (formerly Rhipistoma) we have one or two species that occur on rabbits and other small mammals.

In Ixodes there are several species; one is a European species, $I$. ricinus Linnæus, that occurs occasionally on cattle. In Scotland this species often attacks sheep, and appears to distribute the germs of a 
disease similar to Texas fever, that is known by the name of "louping-ill" or "trembling." The parasite is at present unknown. The loss to Scottish herders is sometimes very heavy. It is said that sheep in moist meadows are not as subject to ticks as those in drier pastures. A pale yellowish or almost white species, with a brighter yellow scutum, I. cruciarius Fitch, occurs on squirrels, gophers, rabbits, ete. In Florida a reddish species, I. scapularis Say, is common.

Of Amblyomma there are a number of species, particularly in the Tropics. A. americana Koch is often found on cattle, and is called the "lone-star tick" on account of a prominent yellowish spot on the scutum. On some species the markings become intricate; a series of yellow and brown sinuate stripes variously interlaced. One of these, $A$. crenata Say (maculata Koch) is very common in the Southern States, attacking almost any mammal, including man. One large species, $A$. tuberculata

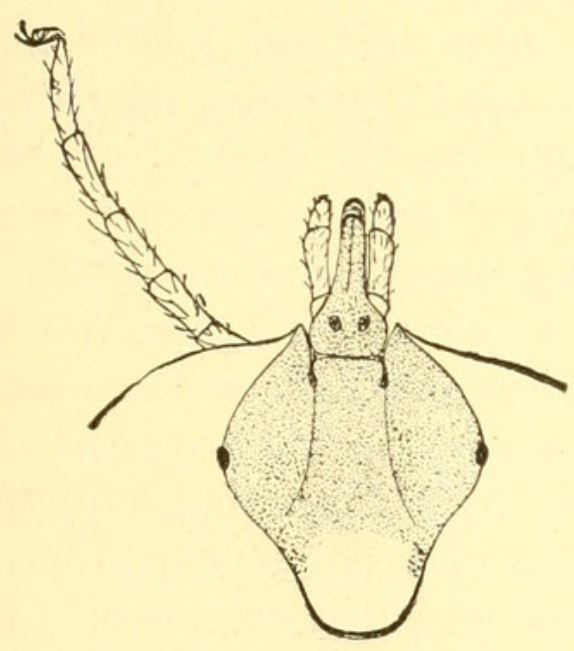

FIG. 84.-AMBLYOMMA AMERICANA, SHIELD OF FEMALE.

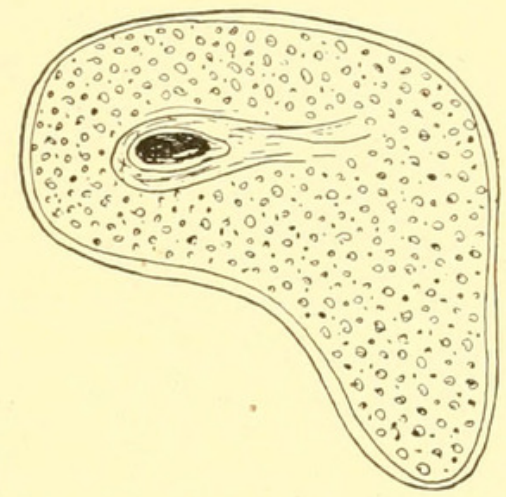

Fig. 85.-AMBLyoma AMERICANA, STIGMAL PLATE.

Marx oceurs on the Floridan gopher. The exotic genus Ophiodes infests snakes; the various species are handsomely marked with brown, red, and yellow. The genus Hrmalastor occurs on bats in Europe.

It has lately been shown that a South African tick, Hrmaphysalis leachi Audouin, is the carrier of a blood-parasite that causes malignant jaundice, or distemper, in dogs in South Africa. The young stages do not communicate the disease, but if an adult tick feeds on infectious blood, her descendants, when adult, may transmit the disease.

\section{Superfamily GAMASOIDEA.}

The Gamasid mites are among those best known to collectors of insects, since many species are very common, and others spend part of their life attached to beetles and other insects. Typically these mites have a hard coriaceous integument, but there are many exceptions to this rule. They are quite flat, broad, and with rather short legs. They have no eyes, but the sense of touch is very highly developed through many hairs on legs and body. Some species are slow in movements, and are apt to feign death when disturbed, but others 
can run with considerable rapidity. The mouth-parts, in many species, may be completely withdrawn into the body of the mite. The mandibles are normally chelate, and the fingers toothed. Sometimes they are greatly elongate and styliform, so fitted for piercing; in a few

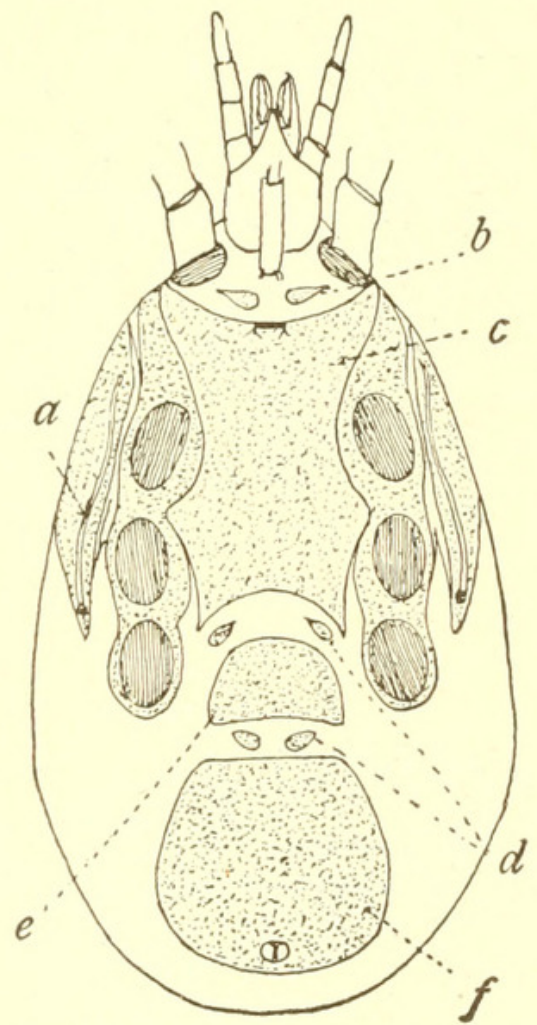

Fig. 86.-VENTER OF GaMASUS. $a$, PERITREME; $b$, JUGULARIA; $c$, STERNAL PLATE; $d$, METAPODIA; $e$, GEN. ital plate; $f$, anal plate. cases the movable finger is lacking. In many species there is a projection or appendage arising near the base of the fingers known sometimes as the "spur," sometimes as the "flagellum." Beneath the mandibles is a large piece, the hypostoma. It is bifid, and each side ends in an elongate corneous point. Between the two corneous points is a long fleshy part, the lingula. The palpi are prominent and usually five-jointed. Above the mouth there is in many forms a thin plate, often toothed, known as the epistoma. In the Uropodidx, the palpi are scarcely visible, as the body projects so much in front. 'The legs are of moderate length, usually slender, and arise close together, in a row each side. In the Uro. podidr the anterior pair is separated from the others and their coxæ are nearly contiguous. The body is commonly provided with coriaceous plates or shields, the position and shape of which are characteristic of each species. These plates sometimes nearly cover the entire body. Their position and names may be observed from the accompanying illustrations. There are some small shields or pieces which are often of importance; a pair just behind the fourth coxæ are called the "metapodia;". a pair just behind coxæ I are known as the "jugularia," and a pair behind sternal plate, the "metasternalia." There are frequently differences between the sexes in the arrangement of the plates, and in the males of many species the ventral plates are mostly

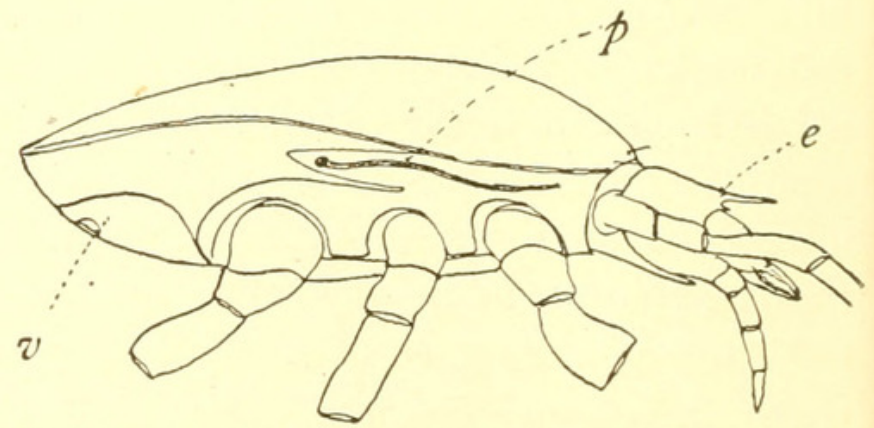

Fig. 87.-SIDE VIEW OF A GAMASUS. e, EPISTOME; $p$, PERITREME; $v$, ANAL PLATE.

coalesced. The female genital opening is commonly under the anterior margin of a plate (the genital) which ends near the coxæ of the third legs. The male genital aperture is usually at the anterior margin of the sternal plate, only a short distance back of the mouth. In some groups, notably the Uropodidx, the genital aperture of the 
male, or of both sexes, is situate in the middle of the sternal plate. The anal opening is small and placed near the tip of the venter; it is often surrounded by a plate. There is a spiracle or breathing pore on each side of the body, above and slightly in front of the

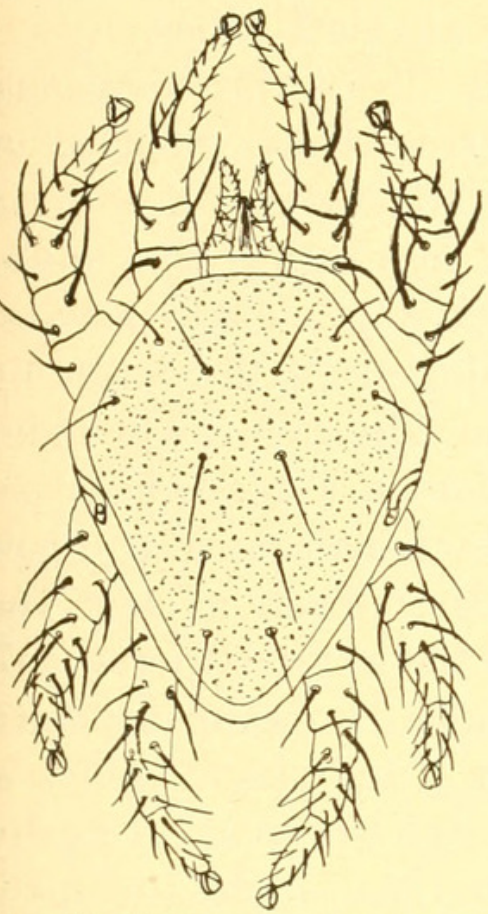

Fig. 88.-PTERoptus AMERICANUS fourth coxa. It is surrounded by a chitinous ring, the peritreme, which usually extends forward for a long distance, often in a slightly sinuous line. The legs are of six joints-coxa, trochanter, femur, patella, and tibia, of subequal length, and a long tapering tarsus. In some species there are indications of a division of the tarsus. The tarsi terminate in two claws, and sometimes a sucker or ambulacrum. In several forms the anterior legs are destitute of claws, and seem to act more as antennæ. In many species the males have the second pair of legs enlarged and provided with teeth and projections, and sometimes the hind legs are also armed. These legs are used to hold the female during pairing.

The internal anatomy of the Gamasidx has been studied perhaps more than that of any other family. It differs in various ways from what may be called the typical acarid anatomy. Kramer has shown that in some forms there is a tendinous framework in the middle of the body, a sort of internal skeleton, to which are attached many of the larger muscles. The male sexual organs are usually on the common plan. There is, however, a large accessory gland lying between and beneath the vas deferens. There is no intromittent organ; and sometimes there are two testes. The female generative organs usually differ much from that in other families. Often there is a semiglobular or botryoidal ovary, opening into one (sometimes two) oviducts, that lead to the vagina; above the ragina is a domed chamber, the spermatheca. At times there are two small glands that open into the vagina. In many forms there is no spermatheca, in which case Michael

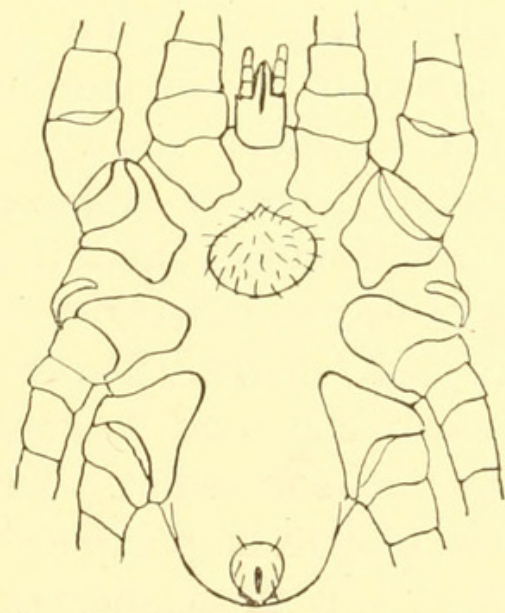

Fig. 89.-VENTER OF PTERoptUS. has discovered the existence of other organs of a most curious nature. Attached to the top of the ovary are two rather clavate arms, known as the lyrate organs; and above is a large sac, the sacculus famineus, connected at one end to the ovary and at the other by two annulate tubes to the acetabula of the coxæ of the third pair of legs. After 
the eggs are all deposited the sacculus becomes very small. Sometimes it is wanting, but the annulate tubes are present and connect direct to the ovary. The significance of these organs is not fully

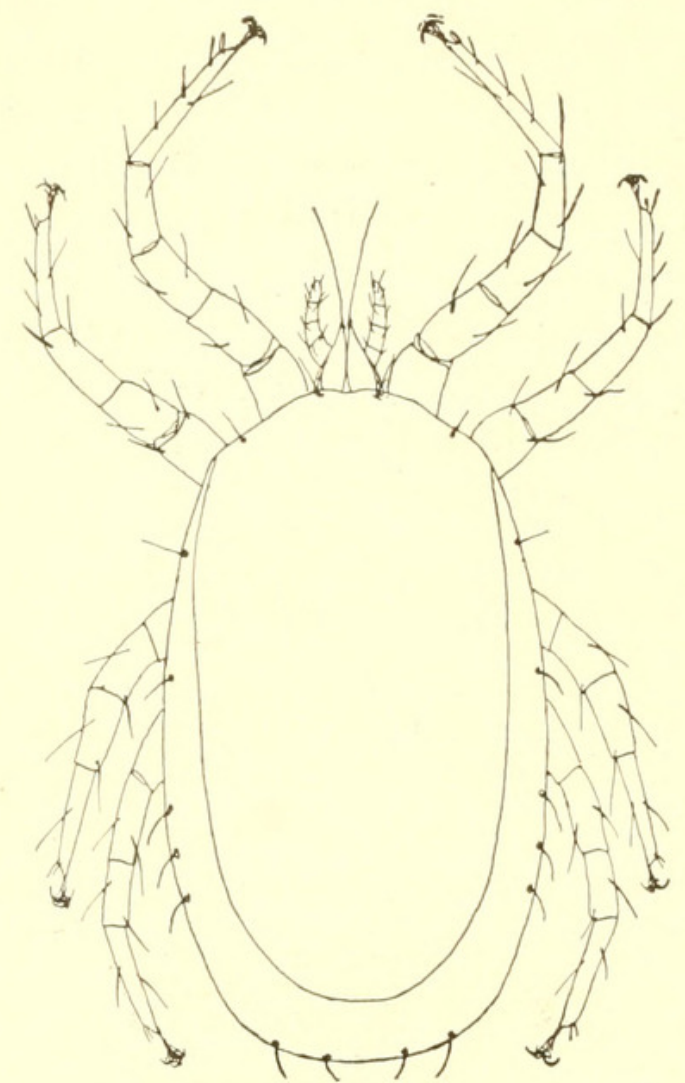

Fig. 90.-DERMANYSSUS GALLINE known, but the sacculus contains spermatocysts which are supposed to reach it through the annulate tubes.

Some, if not all, of the Gamasidæ have a most remarkable method of coition, which Michael has discovered and described in detail. The male, which is commonly a little smaller than the female, clasps the latter by the legs of one side and crawls under her. His abdomen extends back beyond that of the female, and he grasps her by his legs. Then a clear sac emerges from the genital aperture of the male, gradually enlarging until it is of full size and shape, which is constant for each species. Usually this sac or bubble is flask-shaped, with a long neck. It incloses the spermatozoa floating in a clear viscid liquid (sometimes within spermatocysts). The male clasps this bubble with his mandibles, which are often modified apparently for such purpose. The male then applies the small end of the bubble to the vulva of the female, often inserting his mandibles for some distance. Here the small end of the bubble bursts and the liquid and sperma tozoa are discharged into the spermatheca of the female. The bubble is rather firm, and when empty does not collapse, but shrinks somewhat. After the male leaves the female he proceeds to clean his mandibles. In those species in which the female has no spermatheca, but has annulate tubes connecting to the acetabula of the third pair of legs, it is probable that the bubble is applied to these apertures, and not to the
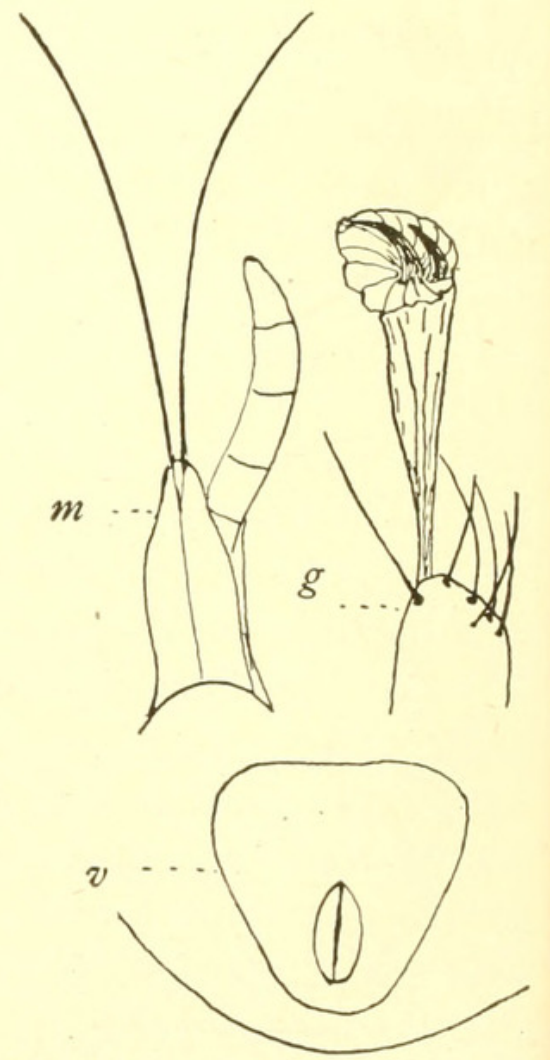

Fig. 91.-DERManysses Galline. $g$, CARONCLE; $m$, BEAK; $v$, ANAL PLATE.

vulva. The spermatozoa thus passing into the sacculus fœmineus, from which they may pass into the ovary as occasion demands. In 
the male of one species there is a hole in the jaw, through which the bubble is blown, part hanging down on either side.

Trouessart has shown that in Raillietia there is a true parthenogen-

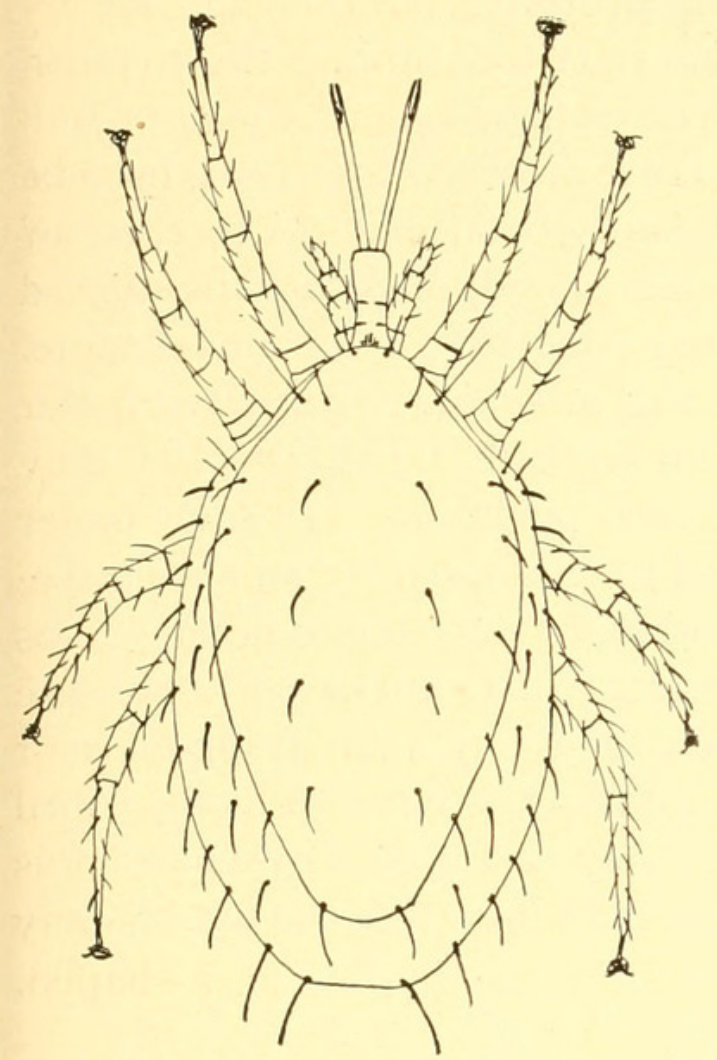

Fig. 92.-Liponyssus AMERICANUS. esis; agamic generations are found in spring and summer, the male appearing only in the autumn or winter. He also found that this form has no nymph, the larva changing into the adult female.

Gamasids deposit eggs which hatch into pale, soft-skinned, sixlegged larvæ, often very different

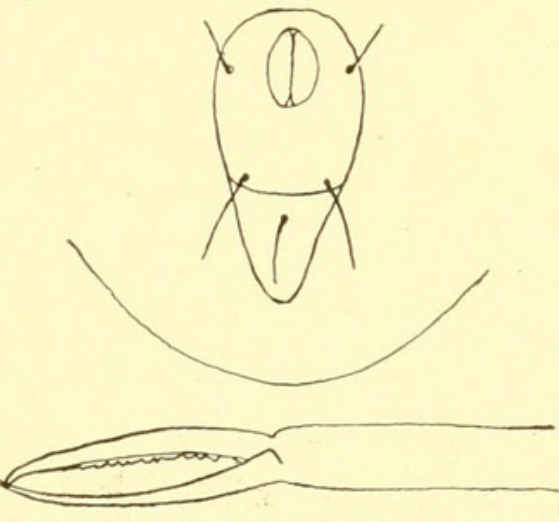

Fig. 93.-Liponyssus; ANal Plate AND MANDIBLE,

from the adult. There is a remarkable exception in Pteroptus and allied genera of the Dermanyssidæ; the young of these mites hatch with eight legs. In time the larva molts into an eight-legged nymph.

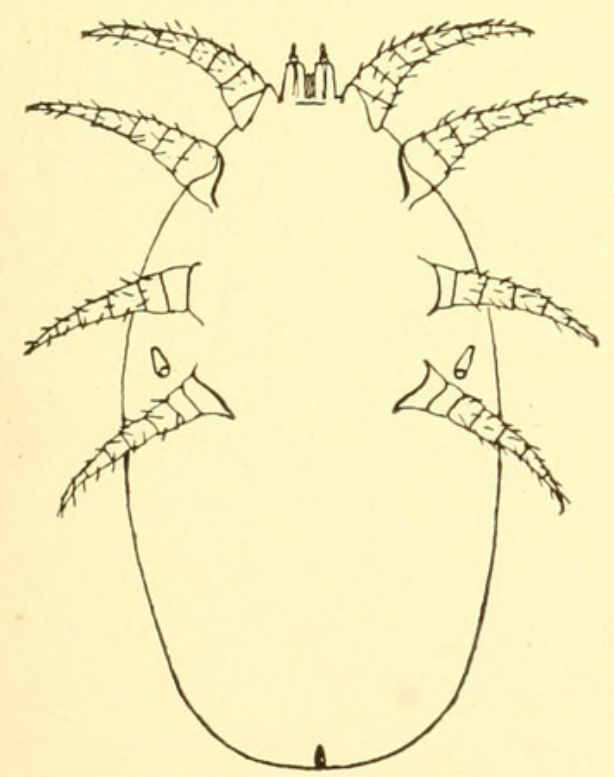

Fig. 94.-PNEUMONYSSUS SIMICOLA, FROM BELOW.

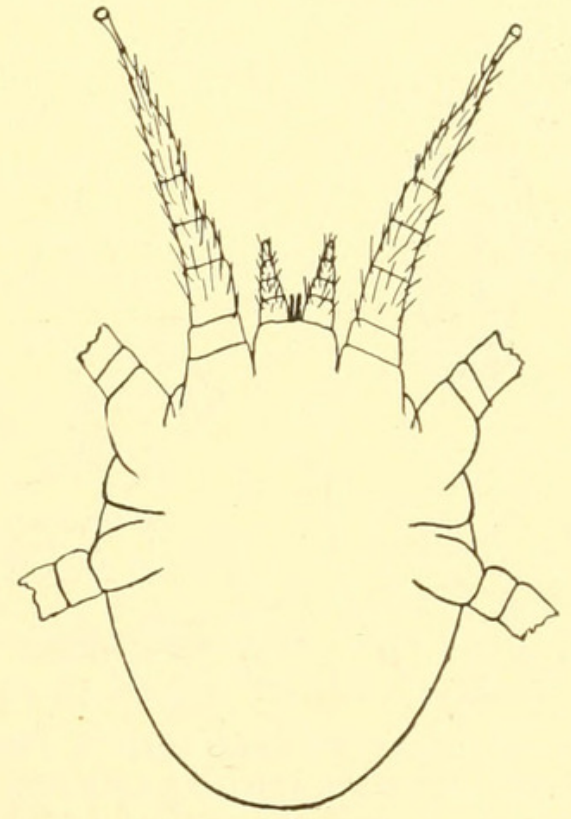

Fig. 95.-LARVA OF PNEUMONYSSUS SIMICOLA.

In this stage they have shields, the dorsal often transversely divided. The nymphal stage is often the longest and most active period of their 
life - the stage of growth and development. After one or two molts in this stage some forms approximate closely in appearance to the adult condition. Hence there are names for the various portions of the nymphal mite, the earlier part being the protonymph, then the deuto-

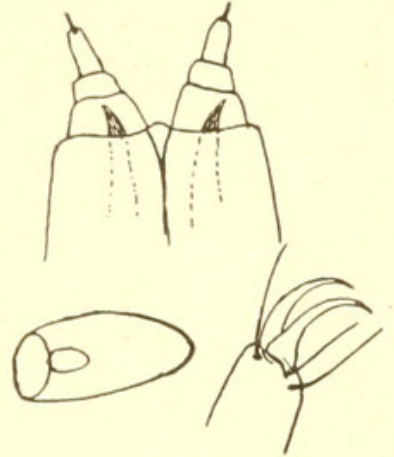

Fig. 96.-PNeUnonyssus; BEAK, CLAWS, AND STIGMAL PLATE. nymph, and sometimes a tritonymph. These terms are applied in the true Gamasidæ. In the nymphal stage some Gamasids are attached to various insects for the purpose of transportation. In fact, some genera (as Uropoda) are chiefly known to us in this migratorial nymphal condition. Various writers have claimed that the mite was a parasite of the insect, but such is not the case. The insect is used only as a means of transportation. In some cases the mite is attached to the insect by an anal pedicel formed of excretions. Such a one is known as a "nympha pedunculata." In some cases the nymph may pair and produce eggs; these are called "nympha pedogenica." The nymph from the larva is often more like the larva in many ways than like the adult. This first nymphal stage is called "nympha heteromorpha." The nymph after molting may look like the adult; this second nymph is the "nympha homeomorpha." These latter two terms are applied only in the Uropodidæ. Some Gamasids live in decaying substances,

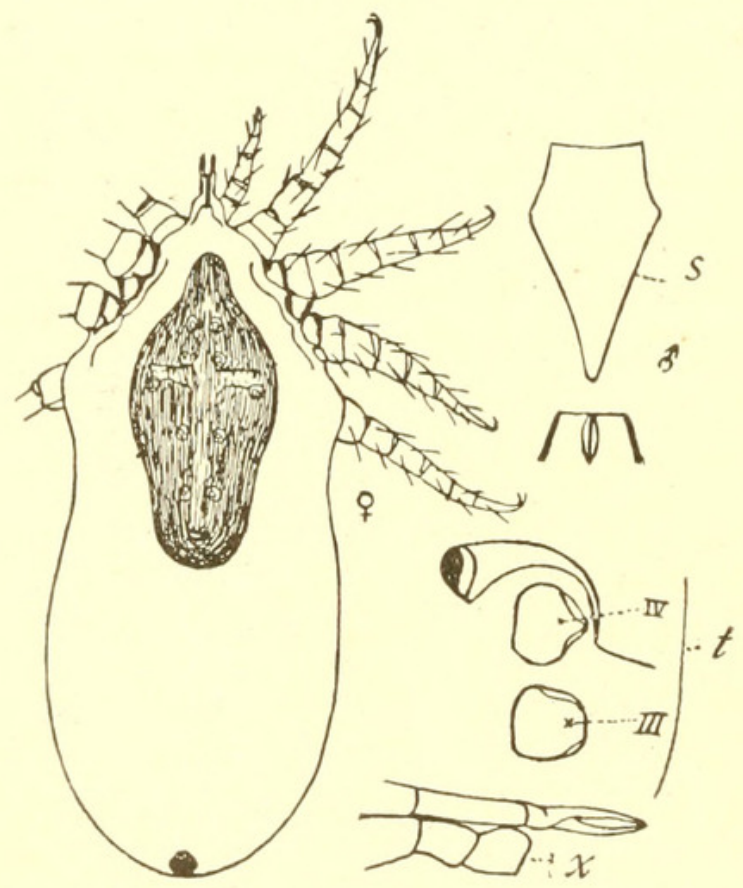

Fig. 97,-HALARACHNE AMERICANA. $s$, STERNUM OF MALE; $t$, STIGMATA AND COX $A ; x$, MANDIBLE.

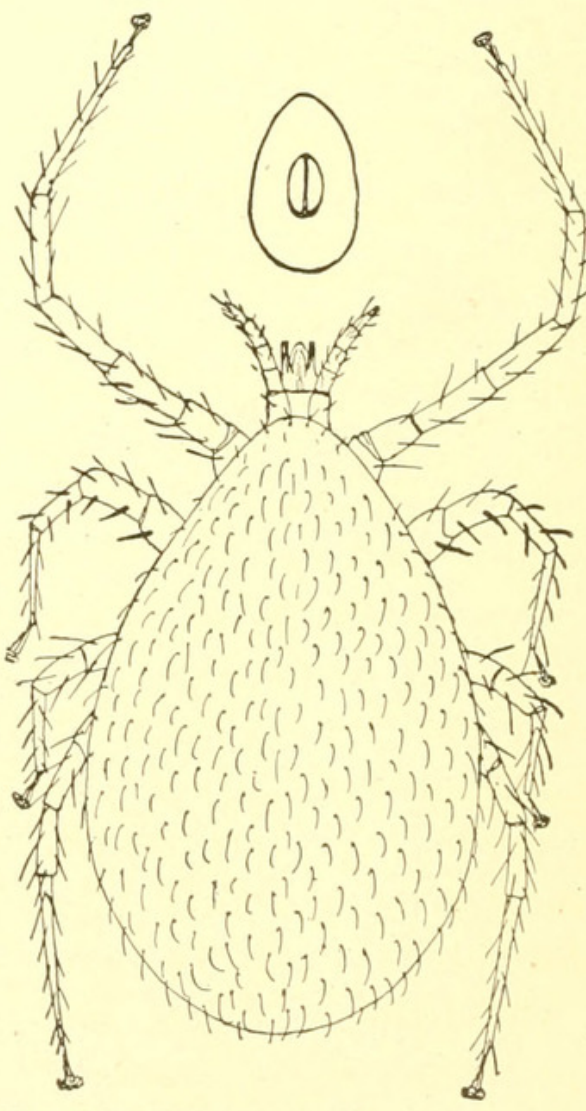

Fig. 98.-HæMogamasus aMericanus, AND ANAL PLATE.

either animal or vegetable. It has been shown that certain Uropodidæ live on minute plants, bacteria, and small fungi. Most species prey on small insects, Thysanurans, other mites, as Tyroglyphidæ and Eriophyidæ, and occasionally they will eat one another. 
There are a few parasitic forms; the entire family Dermanyssidæ is parasitic on birds, bats, rodents, etc. Two genera of the true Gamasidæ

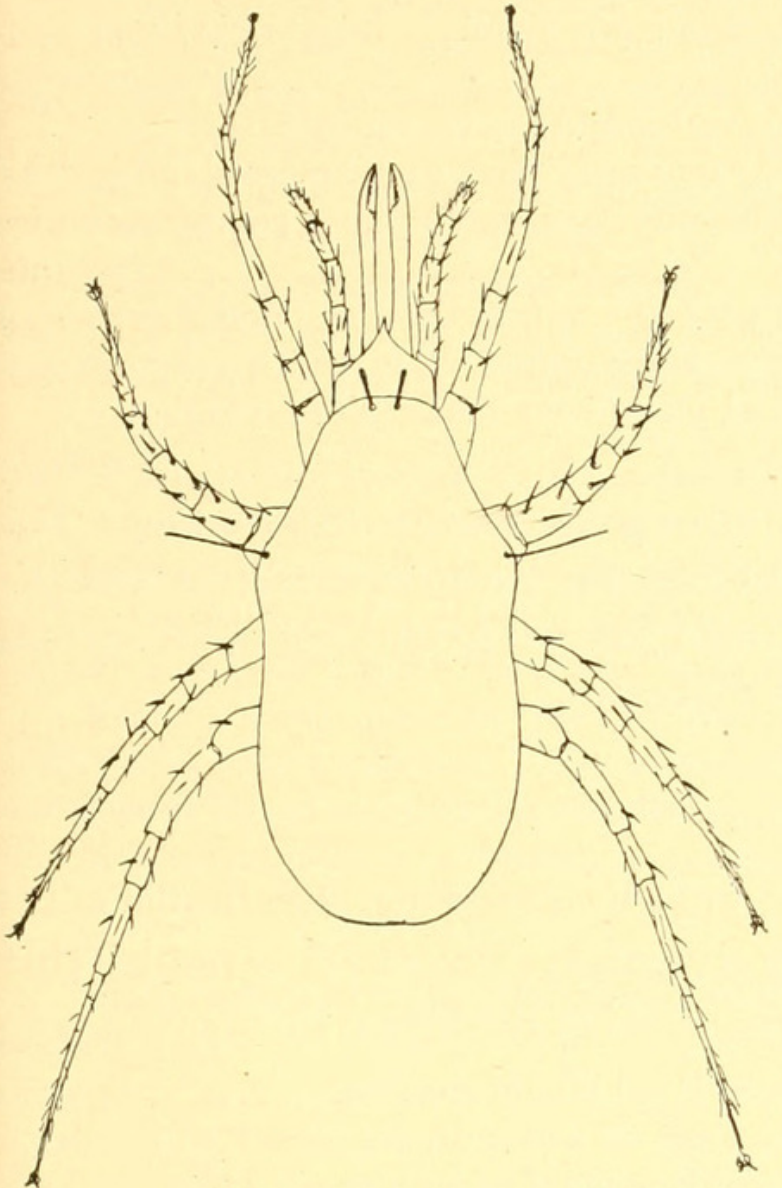

Fig. 99.-GAMASUS SP.

are parasitic-Ilrmogamasus on moles, and Raillietia in the ears of various animals. A great many occur among decaying fallen leaves. A num-

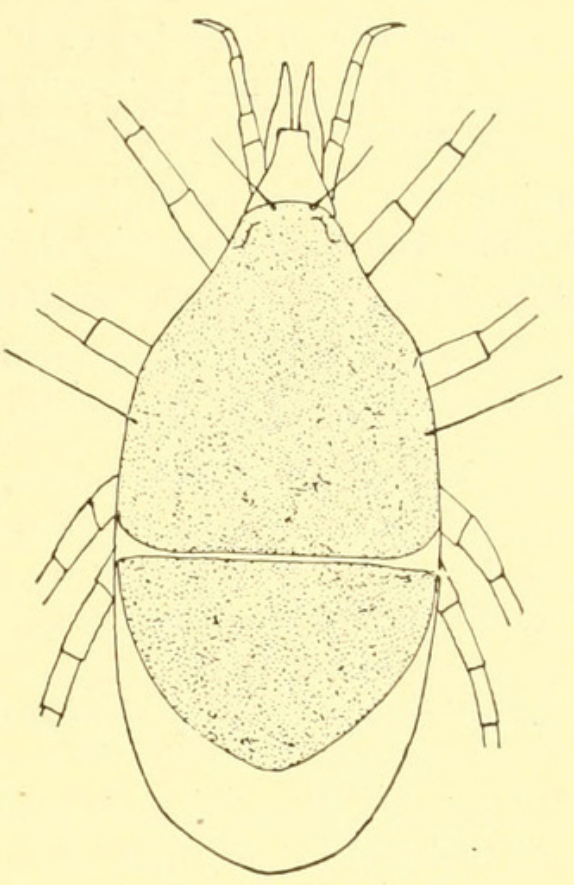

FIG, 100,-GAMASUS SP., NYMPH.

ber of species have been taken in ants' nests. Some of these live attached to the ants and obtain food from them. One species is so found on a Scolopendra. The relationship of the other forms to the ants is not clear in all cases. It has been shown by Michael that some species of Lxlaps feed upon the dead ants. It is therefore probable that most, if not all, of these myrmecophilous forms are scavengers, and their presence useful to the health of the colony. The ants sometimes take care of the mites when the nest is disturbed, and carry them to a place of shelter. One species of Lxlaps, L. equitans, was frequently observed to jump up on an ant and ride about for a while, the ant taking no notice of its rider. It appears that each species of mite prefers to live with a certain species of ant, but several kinds of mites have been found in the same nest. The mites disappear when the ants desert the nest.

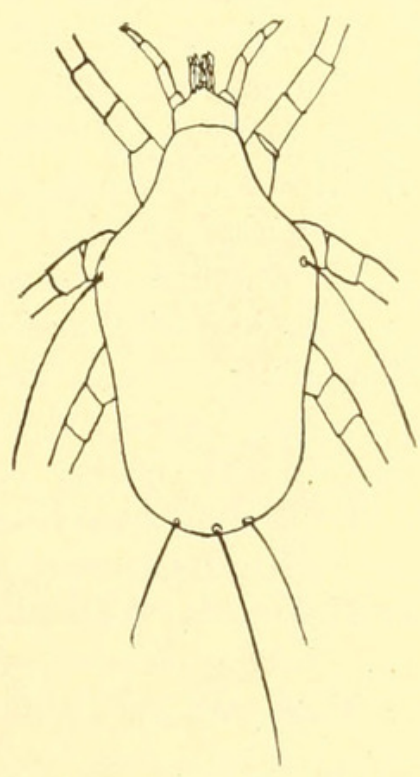

Fig. 101.-Gamasus SP., I.ARVA.

The superfamily Gamasoidea is divisible into several natural groups, the relative importance of which has been variously estimated by different writers. I shall consider that there are 
three families - the Dermanysside, the Gamasidæ, and the Uropodidx. They are not, however, as distinct as one could wish. They may best be separated as follows:

1. Parasitic on vertebrates; mandibles fitted for piercing; body sometimes con-

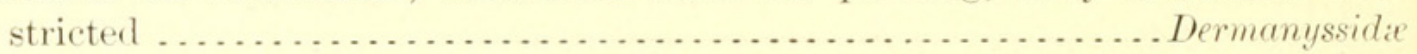

Free, or attached to insects (rarely on vertebrates, never on birds) . . . . . . . . 2

2. First pair of legs inserted within the same body-opening (camerostome) as the oral tube; dorsum of body projects beyond the camerostome; genital apertures surrounded by the sternum............................ Lropodidx First pair of legs inserted at one side of the mouth opening; dorsal surface of body does not project in front of the camerostome, male genital aperture usually on the anterior margin of sternal plate (sometimes in the middle).

Gamasidæ

The true Gamasidx are divided into a great number of genera. The family has not been carefully studied in the United States, so that the following table to the more prominent known genera includes several not yet recorded from the United States:

1. Living in the ears of cattle, horses, etc ........................ Raillietia Living upon moles, or in their nests ........................ Hrmogamasus

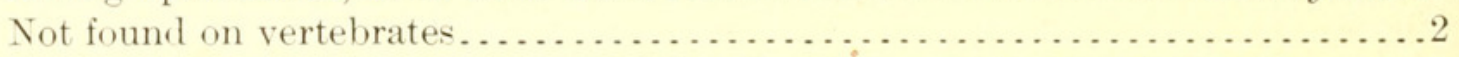

2. No peritreme, only the spiracle; leg I without claws; dorsal shield entire .....3

Peritreme present . . . . . . . . . . . . . . . . . . . . . . . . . . . 4

3. Spiracle elliptical; male genital aperture in anterior margin of sternal plate.

Iphiopis

Spiracle, circular; male genital aperture in middle of sternum......... Epicrius

4. Peritreme very short, about twice as long as wide; dorsal shield entire; leg I with claws; living in a cavity of the abdomen of certain bees (Xylocopa).

Greeniella a

Peritreme more than twice as long as broad; not parasitic on bees..........5

5. Leg I without claws; dorsal shield undivided ......................... 6

Leg I with claws . . . . . . . . . . . . . . . . . . . . . . . . . . . 10

6. A post-anal plate; genital aperture of female between second and third coxæ, and opening by two hinged plates; male with ventral plates united, and leg II

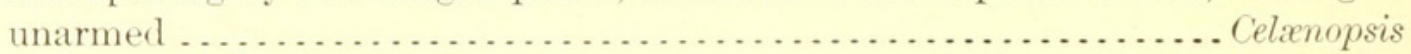

No post-anal plate; female genital opening normal, and farther back . . . . . . . . 7

7. Hind femora with several distinct teeth behind; leg II of male unarmed; male genital opening in middle of sternum ......................... Misthanus

Hind femora unarmed, or, if so, then leg II is enlarged and armed in male, and male genital aperture on anterior margin of sternal plate............... 8

8. Peritreme not extending in front of coxie III; body short; legs short; male with leg II unarmed; male genital aperture opens in middle of sternum; attached

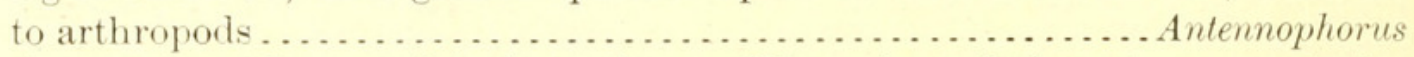

Peritreme extending much in front of coxæ III; male genital aperture on anterior

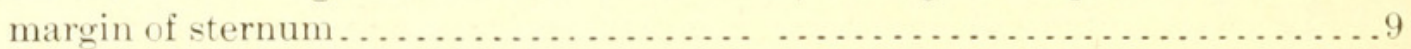

9. Male with leg II enlarged and armed with teeth; female often with metasternalia; peritreme often curved at base; body more elongate ............. Mucrocheles Male with leg II unarmed; all legs very long; female without metasternalia.

Podocinum

10. Middle of dorsum with two small shields each side, a larger one at tip, and a very large one in front ..............................................

Dorsum without such arrangement of shields, usually one, or one transversely divided ...

« New name to replace Greenia Oudemans (1900), preoccupied by Kirby in 1896. 
11. Male genital opening in middle of sternal plate; body rather short and usually

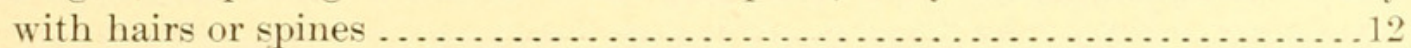

Male genital opening on anterior margin of sternal plate $\ldots \ldots \ldots \ldots \ldots \ldots . . .13$

12. Peritreme rather short; dorsal shield divided; leg II of male unarmed ... . Zercon Peritreme long; dorsal shield entire; leg II of male armed with teeth..... Seiodes

13. Leg II of male unarmed; body usually egg-shaped; dorsal shield entire . . . . 14 Leg II of male armed with teeth; body usually longer . . . . . . . . . . . . . 16

14. Male with ventral plates all united; anal plate separate in female; female genital plate not angulate in front . . . . . . . . . . . . . . . . . . . . . . . . . . . . . . . . . . . .

Anal plate separate in both sexes . . . . . . . . . . . . . . . . . . . 15

15. Anal plate broad; epistoma scarcely pointed . . . . . . . . . . . . . . . Seius

Anal plate small and narrowed behind; epistoma usually with a mucronate

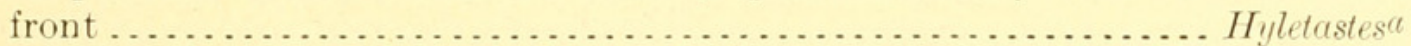

16. In female the sternal plate reaches behind hind coxr; the ventral and genital plates united, the anal separate . . . . . . . . . . . . . . . Pachylxlaps

In female the sternal plate scarcely reaches hind coxi; the ventral plate often united to anal, but not to genital . . . . . . . . . . . . . . . . . . . . 17

17. Female genital plate triangular, angulate in front . . . . . . . . . . . Gamasus

Female genital plate rounded in front. . . . . . . . . . . . . . . . . . 18

18. Dorsal shield entire. . . . . . . . . . . . . . . . . . . . . . Hydrogamasus

Dorsal shield more or less divided . . . . . . . . . . . . . . . . . . . . . . 19

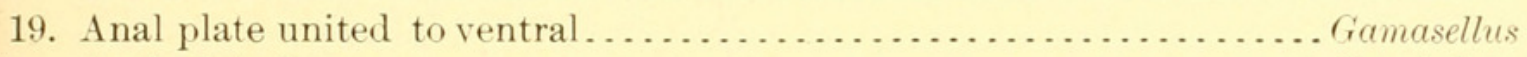

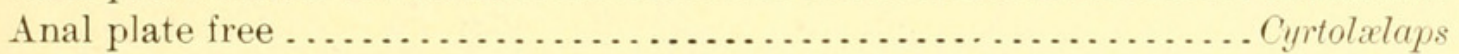

The genus Raillietia is based on R. auris, which was found by Leidy in the ears of cattle in this country. Of Iphiopsis and Epicrius no

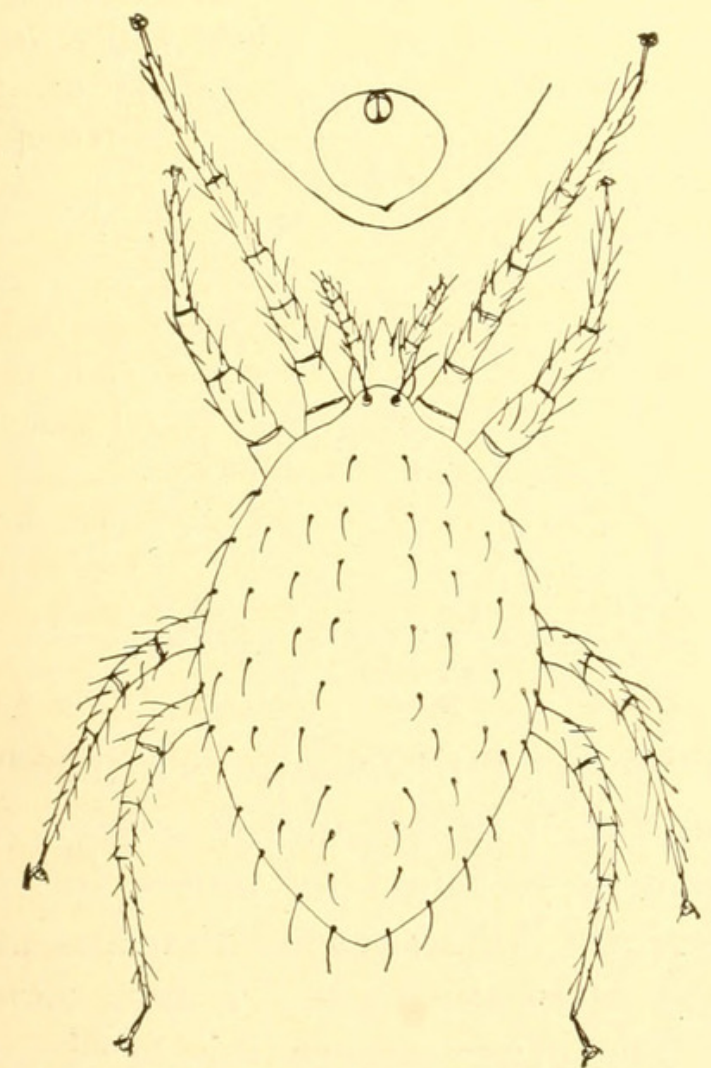

Fig. 102.-Hyletastes SP. AND ANAL Plate.

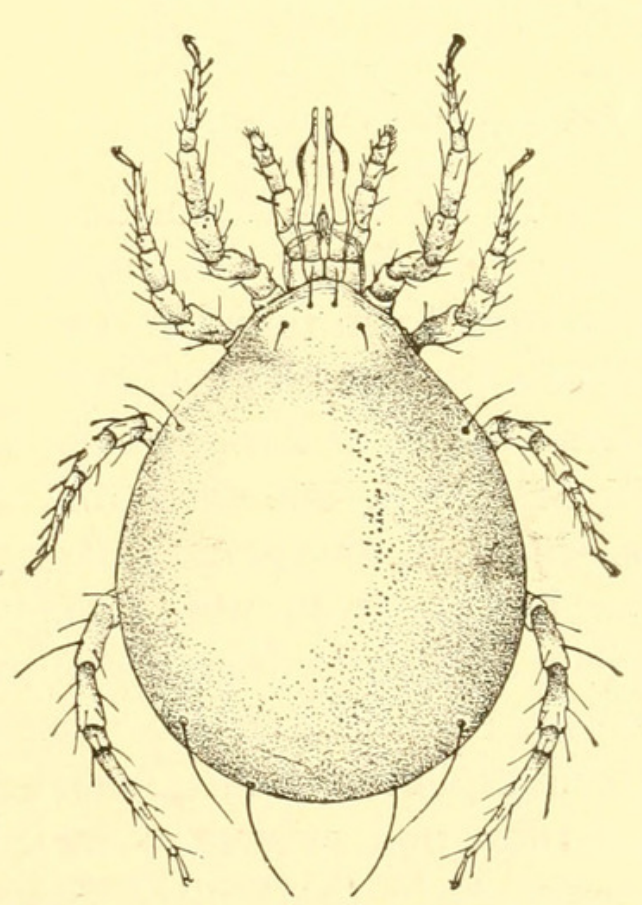

Fig. 103.-HYletastes OVALIS (PERGaNDE).

species have been found in this country; the latter often has a regular pattern of tubercles on its dorsum. A species of Celzenopsis has been 
taken in Indiana and the District of Columbia on- a Histerid beetle, Hololepta. Megisthames includes a number of large tropical Gamasids, recognized by their large size and toothed hind femora. One species, M. Aloridanus Banks, has been taken in Florida. Antennophorus has a very short, broad body, with short, stout legs. The first species was found in Europe abundantly attached to certain ants, and its habits have been studied by Wasmann and Janet. One species, A. wheeleri Wasmann, has been recorded, from the United States on ants. Macrocheles includes some of our most common species, but they have not been described, except one ( $M$. mostus Banks) which

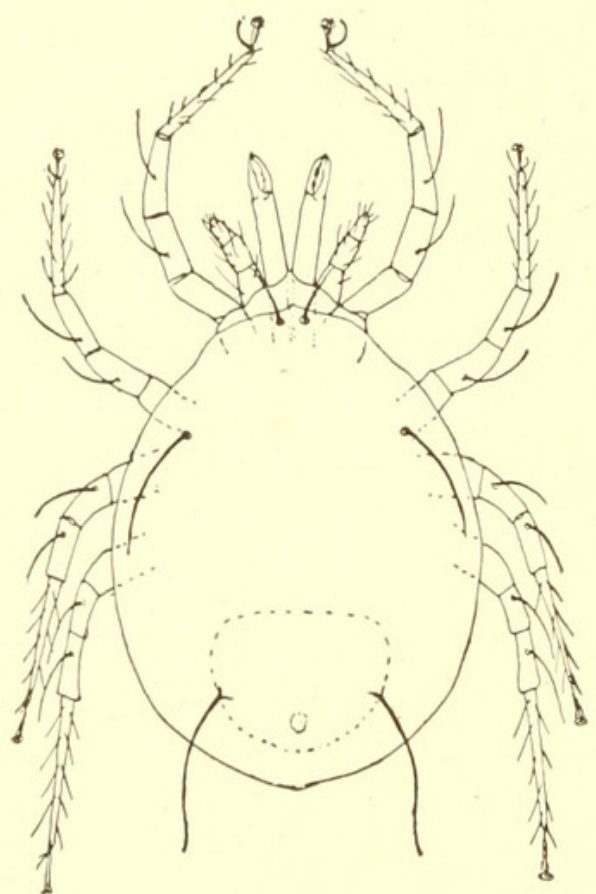

FIG, 104.-SEJUS QUADRIPILIS.

occurs in the nest of an ant, Lasius americanus. Liroaspis is a strange form found in the northern part of the country. Several species of Lxlaps have been described, one from the nest of an ant, another, L. pla-

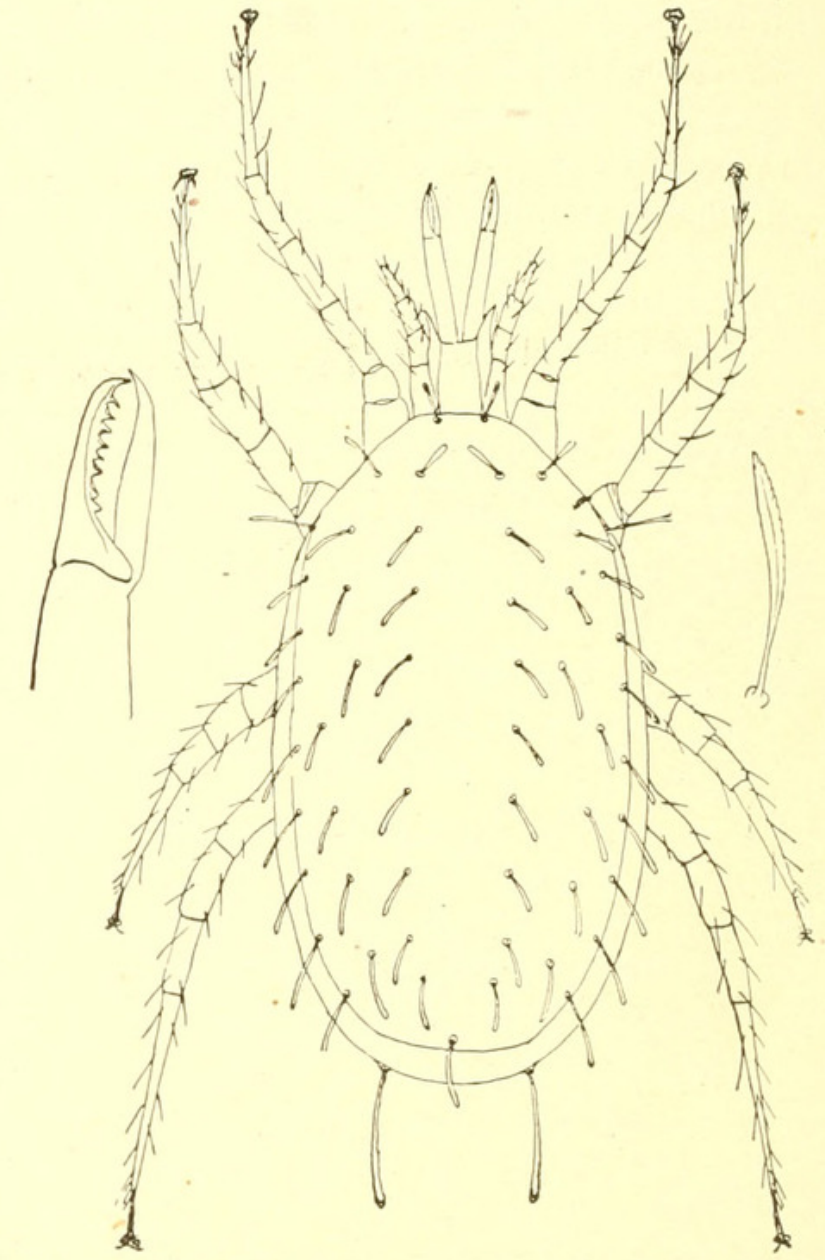

Fig. 105.-LELAPS MEXICANUS, MANDIBLE, AND ENLARGED HAIR,

cidus Banks, from wet sphagnum moss. Of Gamasus we have a number of species that occur among fallen leaves, on the ground, in rubbish, etc. The genus Irxmogamasus is found on moles and in their nests, both in Europe and America. All stages are found at the same time, and evidently suck blood from the mole. I have taken one species in the United States. The other genera tabulated are known in Europe, and several others have been described from South America.

Berlese has recently divided Lxlaps into several genera, one of them, Myrmonyssus, from forms on ants. Ribaga has also divided Seiulus or Seius into four subgenera. 
The Dermanyssidæ, though differing much in general appearance from the Gamasidx, are closely allied by structure, and their parasitic habits are the best character for the separation. Probably it would be better to abandon the group. The principal genera can be arranged as follows:

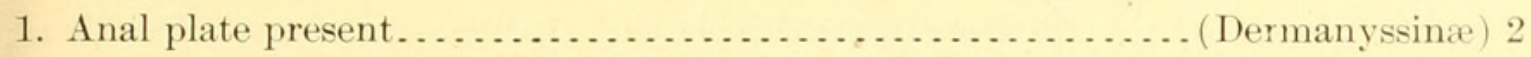

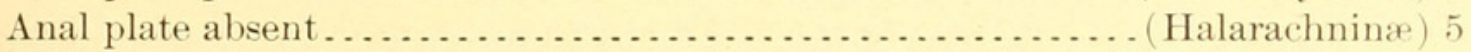

2. Body short; legs very stout, hind pair reaching much beyond the tip of body.

Pteroptus

Body longer; hind legs not reaching beyond the tip ................... 3

3. Peritreme on the dorsum, very short; body very distinctly constricted. Ptilomyssus Peritreme on venter, longer; body not distinctly constricted . . . . . . . . . . . . 4

4. Mandibles in both sexes chelate; parasitic on bats and mice .......... Liponyssus Mandibles in male chelate, in female long, styliform; parasitic on birds.

Dermanyssus

5. Dorsal shields present; coxæ close together; living in seals Halarache No dorsal shields; hind coxæ separated from the fore; living in monkeys.

Pneumonyssus

Pteroptus, which is parasitic on bats, is remarkable on account of

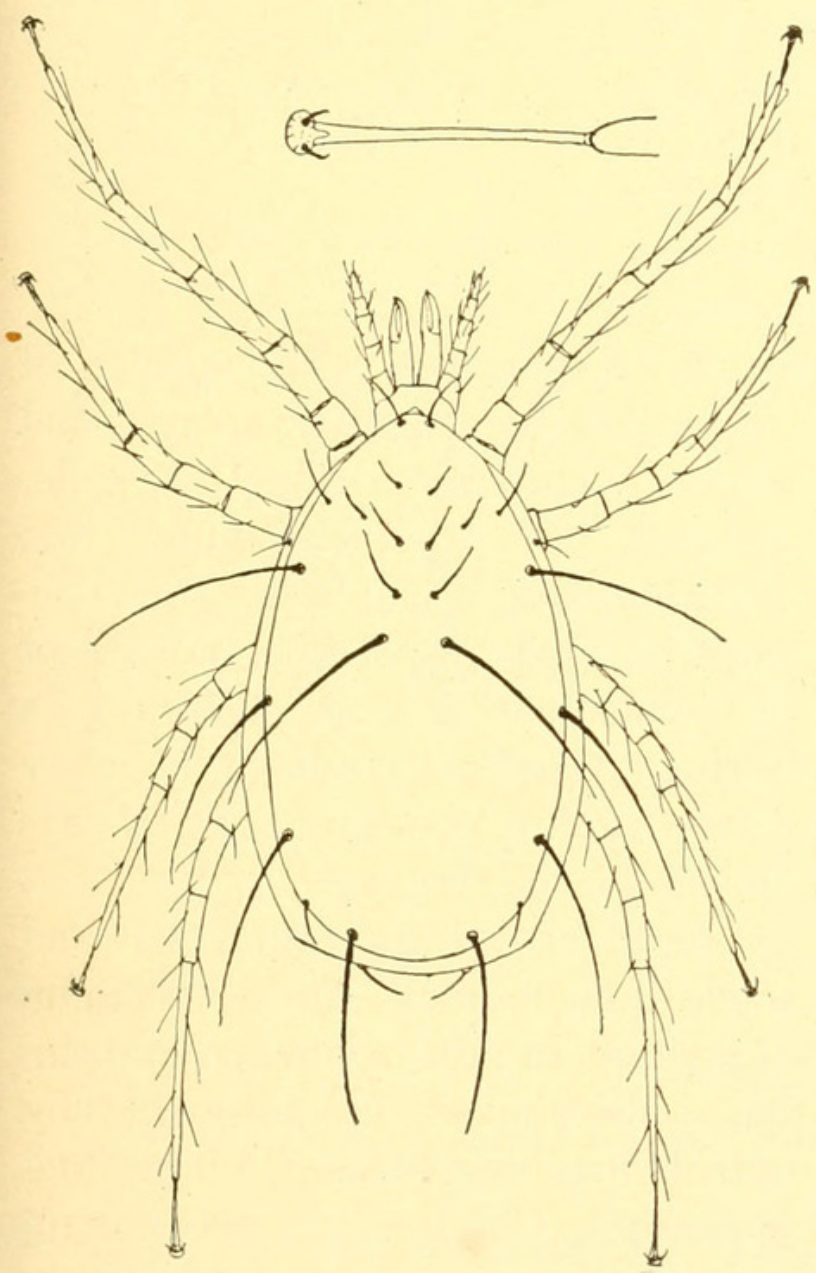

Fig. 106.-L.Llaps MACropilis AND CARONCle OF TARSUS IV.

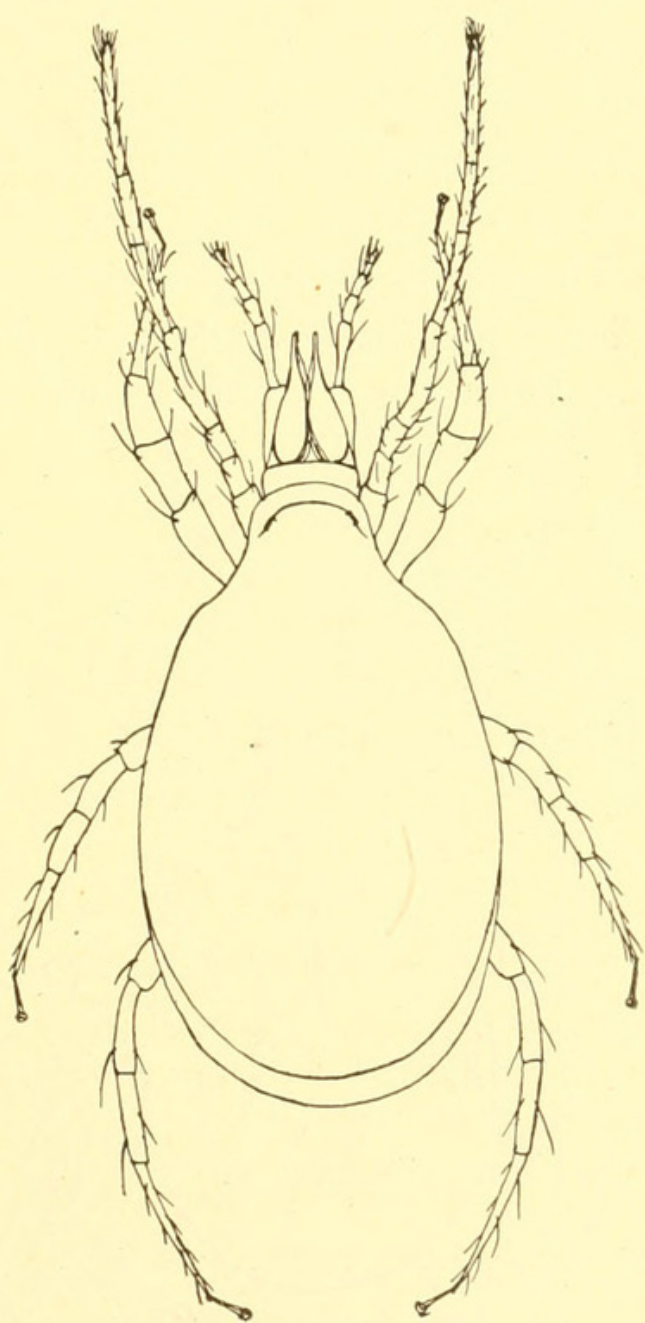

Fig. 107.-MACrocheles CAROLINENSIS, FEMALE.

its curious shape, dorsal position of the stigmata, and also on account of the young hatching with the full complement of legs, the larval 
stage having been passed in the mother. The abdomen is practically

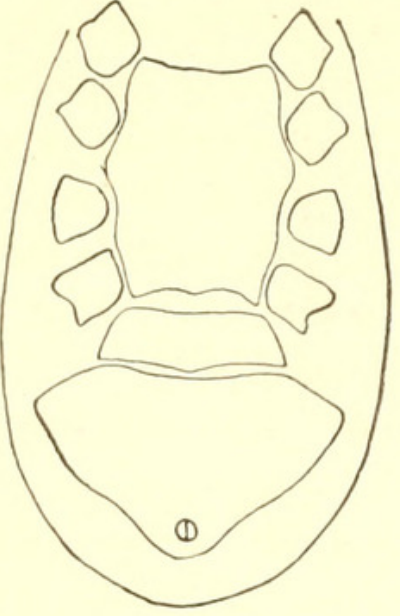

FIG. 108.-II A R OCH ELES CAROLINENSIS; VENTER OF FEMALE. wanting in the male, and in the female it is extremely small. The short, thick, bristly legs are set at about equal distances around the body. Although the stigmata are on the dorsum, the peritreme extends down over the sides and upon the venter. Doctor Oudemans has described an accessory nymphal stage in one species of this genus. It occasionally issues from the second nymphal stage, and differs particularly in the nature of the vestiture. Its use is unknown. One species has been described from our country. The allied genus $P e$ riglischrus differs in having the dorsal shield divided, and the peritreme does not extend down on the venter. The female has a wrinkled fan-shaped expansion to tip of body, by which she retains hold of the skin of the bat. Kolenati described several allied genera, but most, if not all of them, are stages of Pteroptus.

The genus Ptilonyssus differs in having a large abdomen, separated by a constric-

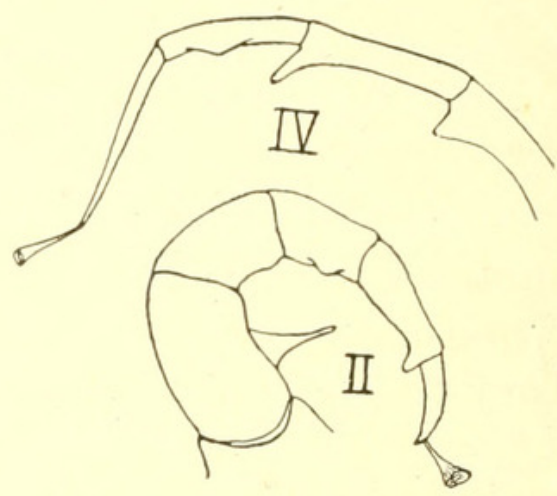

Fig. 109.-Macrocheles SPINATUS; LEGS II AND IV OF MALE. tion from the cephalothorax; it occurs on sparrows. The species of

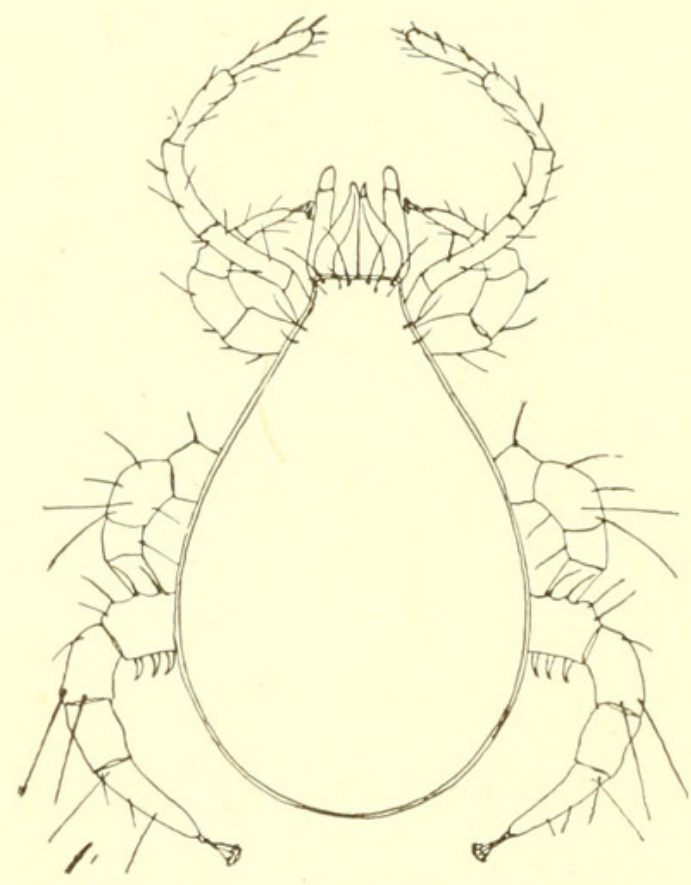

FIG. 110.-MEGISTHANUS FLORIDANUS.

Liponyssus are parasitic on mice and similar mammals. They are palecolored, but otherwise much like Dermanyssus. The latter genus occurs on birds, especially those kept in domestication. D. gallinx is a serious pest of poultry in many parts of the country. They hide in cracks and crevices by day, but at night crowd upon the fowls and suck their blood. They are more injurious in the Southern States than elsewhere. Sometimes they attack man and cause itching and soreness. Chickens endeavor to get rid of the mites by a dust-bath, but when the mites are numerous, it will be best to spray or wash the hen-house with kerosene, benzine, or gasoline. Whitewashing with carbolated lime will destroy a great many of them. If the 
ends of the roosts are daubed with coal-tar the mites will be unable to reach the fowls. A mixture of kerosene and sulphur plastered upon the roosts and in bottoms of the nests is also very useful. The same or an allied species occurs on cage birds. The species of Halarache are

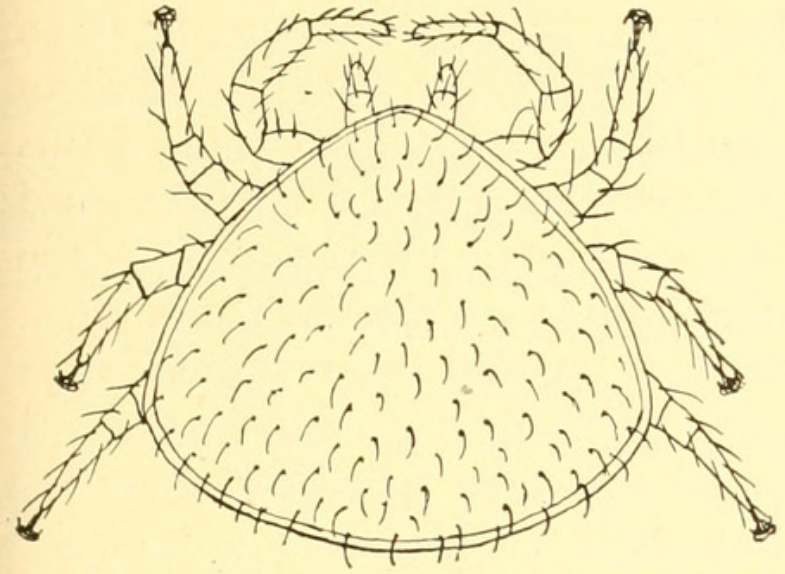

Fig. 111.-ANTENNophorus UhLMANNI (AFTER HALLER). very elongate, and look somewhat like ticks; they inhabit the branchial passages of seals. Pneumonyssus occurs in cavities in the lungs of a Javanese monkey.

Doctor Trouessart has erected a subfamily, Rhinonyssinæ, to include Rhinomyssus, Ptilonyssus, Sternostomm, and possibly IIalarache. The group is based on the dorsal position of the peritreme. The species of Rhinomyssus and Sternostomum are found in the nasal cavities of various birds, one species, $S$. rhinomlethrum, thus infesting the domestic fowl. They have retractile claws, comparable to those of cats, which enable

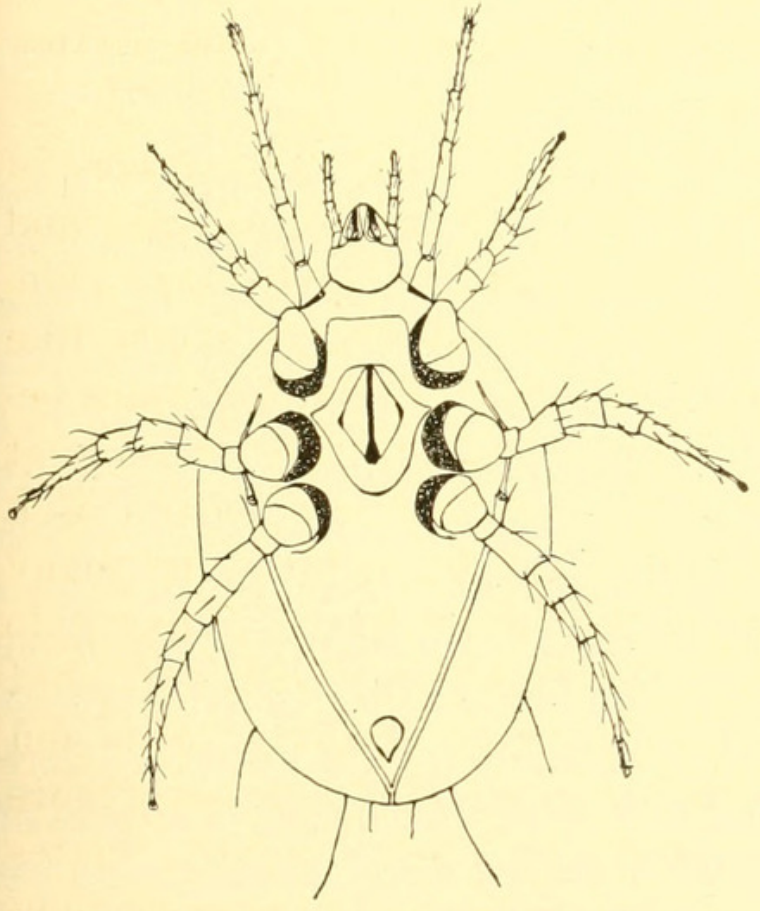

FIG. 112.-CELENOPSIS AMERICANA.

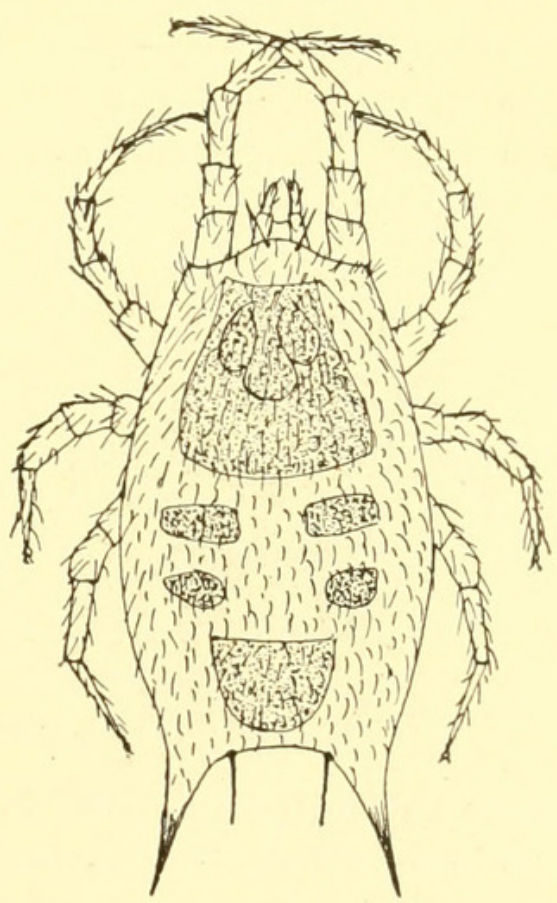

Fig. 113.-LIROASPIS AMERICANA.

the mite to retain its position. Their feeding may cause a catarrhal inflammation, but no remedy has been suggested. I am not aware that any of these forms have yet been taken in the United States. Berlese states that in Sternostomum and Ancystropus the anterior coxæ are contiguous abore the rostrum. The latter genus was found on bats. 
The Uropodidx are divisible into comparatively few genera. In general appearance they are quite different from most of the Gamasidæ, being shorter and their legs more or less

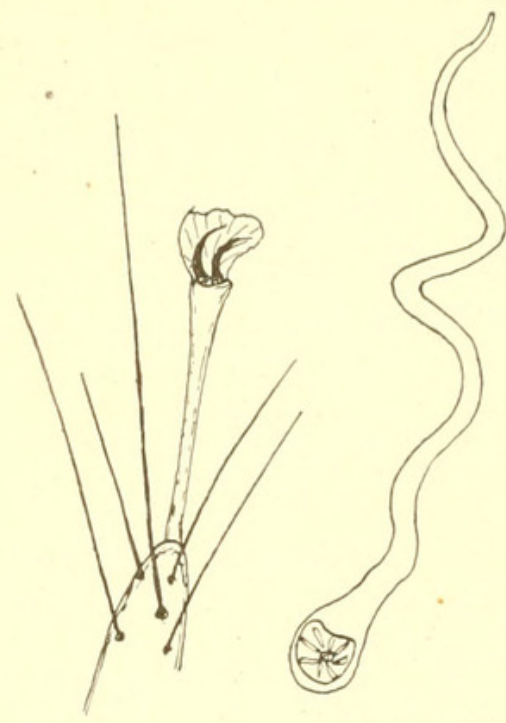

FIG. 114.-UROPODA; CARONCLE AND PERITREME. hidden under the body. They are familiar to most entomologists when attached to beetles and other insects. Besides the characters given in the table for the separation of these forms from the Gamasidæ, it may be added that the mandibles are very long and slender, ending in delicate chelæ. In fact the mandibles in some species are twice the length of the body, and when retracted the bend near the middle is near the posterior walls of the body. Most of the Uropodide that are found on insects are there for the purpose of transportation and not as parasites, but in certain forms found on ants the mite is a true parasite. The species that use the insect as an aid

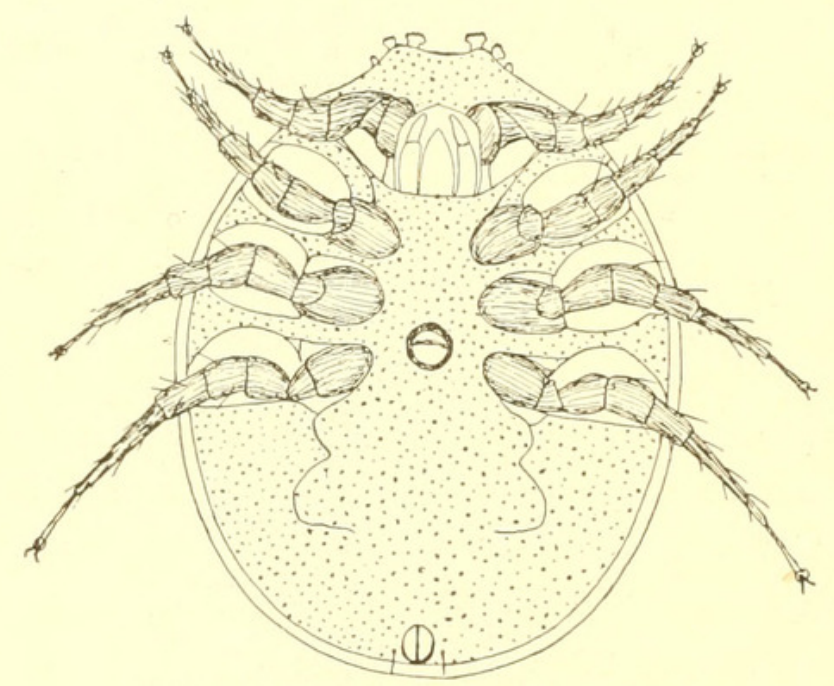

Fig. 116.-UROPODA SP., FroM BELOW. to migration are attached thereto by a pedicel of excrement; those that are true parasites are not so attached. Most of those that are attached by this anal pedicel are not adults, but in a nymphal stage, and are called "mympha pedunculata." The mite can detach itself by a fresh excretion. They occur on insects that breed in places suitable for the mites. There-

fore the mites are sure to be carried to a spot where they can drop off and find the desired breeding grounds-decayed wood, humus, manure, or fallen leaves. Sometimes the insect is so completely covered by the mites that it can not be seen.

The genera may be tabulated as follows:

1. Venter provided with impressed fover for the reception of the legs........ 2

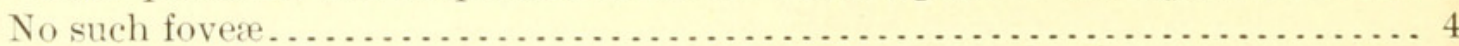

2. Body irregular, dorsum sculptured . . . . . . . . . . . . . . . . . . . . . . . . . Body regular in form; dorsum evenly convex; no sculpture, except punctuation. 3

3. Leg I provided with claws . . . . . . . . . . . . . . . . . . . . . . . . . . . .

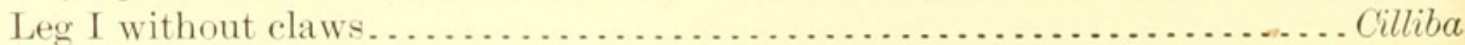


4. Leg I without claws. . . . . . . . . . . . . . . . . . . . . . . . 5

Leg I with claws. . . . . . . . . . . . . . . . . . . . . . . . . . . . . . . 6

5. Legs with scale-like hairs; dorsal and ventral plates separate and distinct. . Polyaspis Legs without such hairs, no ventral plate ...................... Uroseius

6. Dorsum covered by one plate fused to the ventral plate; peritreme sinuate; ante-

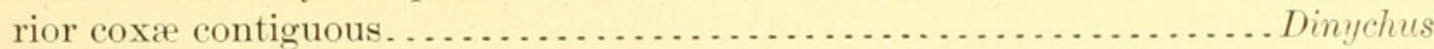

Dorsum with several plates, not fused to the ventral plates; peritreme but little curved; anterior coxæ separate . . . . . . . . . . . . . . . . . . Trachytes

Our species of the family have been but little studied, and only three of the above genera are known in this country.

Species of Uropoda are frequently found attached to various beetles. One of these is common on the Colorado potato beetle, and it was formerly supposed by many eco-

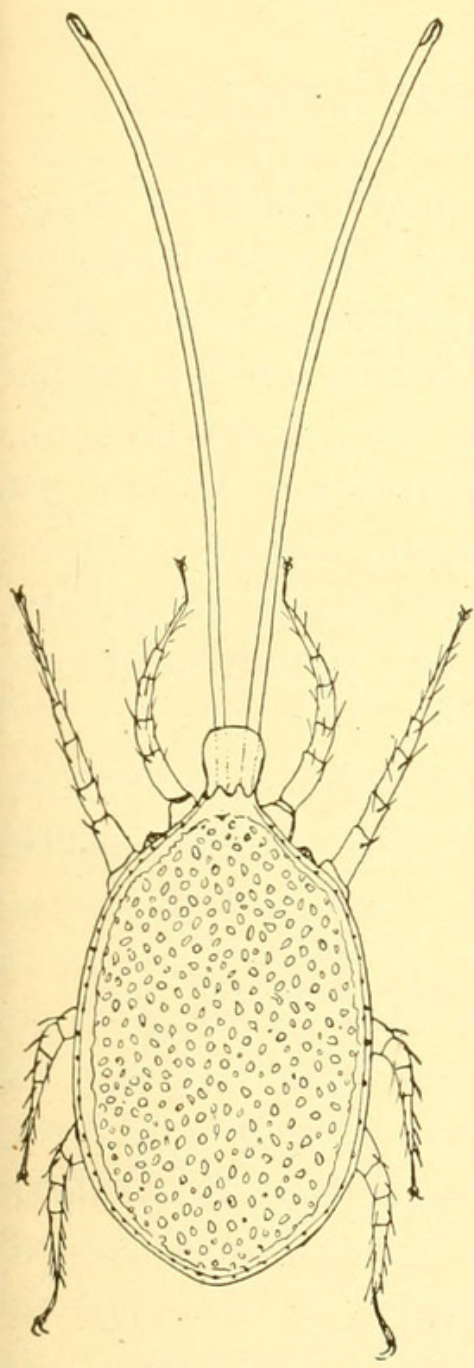

Fig. 118,-Dinychus AMERICANUS, nomic entolomologists that the mites fed upon the beetle. It has lately been claimed that some species feed on bac-

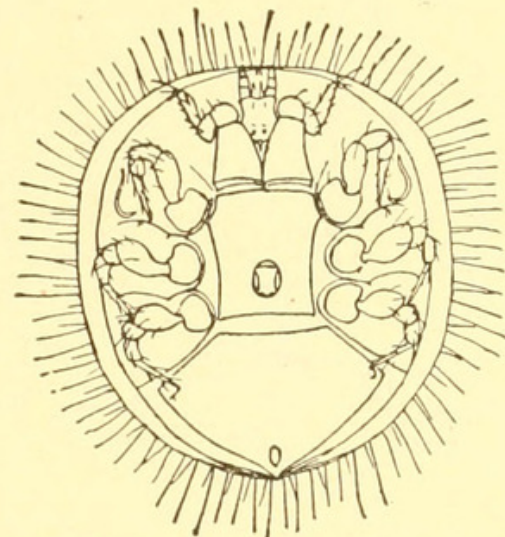

Fig. 117.-CILlibA HIRSUTA, FroM BELOW, teria and small fungi. The species are very numerous; some are smooth, others hairy; nearly all of a red-brown fawn color. The species of Glyphopsis have usually been found in ants' nests, and seem to live on good terms with the ants, although their exact status is not known. Uroseius and Polyaspis are based on a few forms, and not well known.

Trachytes contains two or three pyriform species found in moss; the genus was formerly called Celæeno. Cilliba (formerly known as Discopoma) is similar in appearance to Vropoda. Some species have been found in moss, but others occur parasitically upon ants, attached to the thorax or abdomen. One of our species, $C$. circularis Banks has been found thus fastened to the thorax of Cremastogaster lineolata. Another species, C. liirsuta Banks, was taken upon a species of Lasius in Arizona.

The relations existing between the Discopoma and the ant has formed the subject of several recent investigations, both by Wasmann and by Janet. The mites which cling to the abdomen of the ant do not seem to be disturbed by the ant, but if a mite was placed on the ground of the nest it was seized and destroyed by the ants. The mites bite through the soft skin situated between the segments, and thus draw blood from their hosts. 
The genus Dimychus is peculiar in having enormously long extensile, flexible mandibles. The mandibles are more than twice as long as the
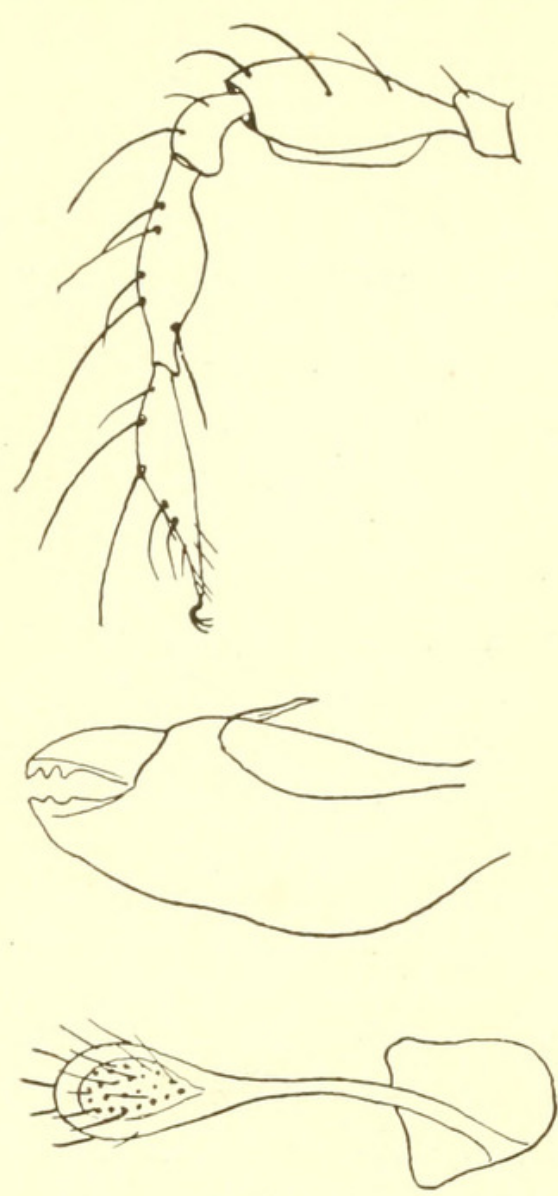

Fig. 119.-LEG, MANDIBLE, AND PSEUDOSTIGMATIC ORGAN OF AN ORIBATID. entire animal, and can be retracted so that the bend in them is close against the posterior walls of the abdomen. The tips of these mandibles are distinctly chelate. We have one species in this country.

From New Guinea, Canestrini has described several species of a remarkabie genus-Derciophorus. They have a pair of plate-like projections over the head, and from these arise long bristles, and there are also bristles at tip of abdomen. Two other genera, Tropodella and Fedrizzia, have been described from tropical countries.

\section{Superfamily ORIBATOIDEA.}

The Oribatid mites may usually be recognized by the presence of a single character, a hair or seta arising from a small pore near each posterior corner of the cephalothorax. This pore was formerly considered a spiracle, but it is now known not to be such. It function, however, is uncertain, and it is called a pseudo-stigmata, while the hair arising therefrom is known as the pseudo-stigmatic organ.

With the great majority of the Oribatidæ the tegument is coriaceous; it is because of this that these mites have been called "beetle mites." This name is somewhat misleading, as members of another family, the Gamaside, are often attached to beetles, and therefore sometimes termed "beetle mites."

The body of an Oribatid is short, broad, and usually high. There is always more or less indication, usually very plain, of the division into cephalothorax and abdomen. There is at this point a constriction on the sides, a line or suture on the venter,

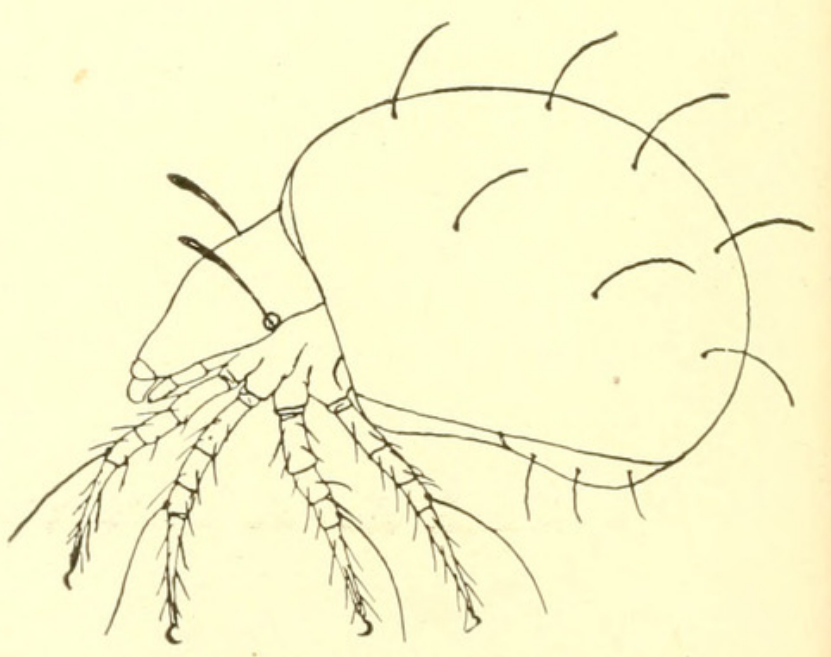

Fig. 120.-Hoploderma SPHERULA. and a break in the continuity of the dorsal outline. The posterior pairs of legs are apparently attached to the abdomen. The coxæ of the legs 
are arranged in a somew hat radiate manner, and the hind pairs are never remote from the anterior pairs. Each leg is composed of six joints, namely, coxa, trochanter, femur, patella, tibia, and tarsus. Sometimes there is a plate-like expansion near base of coxæ, known as a tectopedium. The coxre are usually entirely united to the ventral surface of the body to form a sternal, or, more properly, a coxal plate, each coxa usually being margined by a short furrow. In Nothers, however, the coxæ may be seen to be quite distinct from the body. On the first two pairs of legs the trochanter is extremely small and usually indistinct, while this joint is often very large on the hind pairs. So it follows that the hind legs have, apparently, one more joint than the

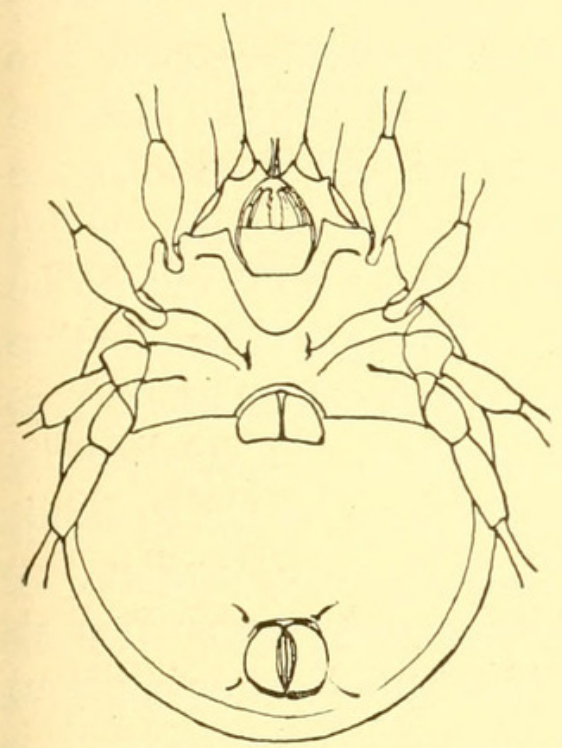

Fig. 122.-GALUMNA SP., From BELOW. front pairs. The tarsus is terminated by one or three claws, but without a sucker or pulvillus. The legs bear a few hairs, but never many; one

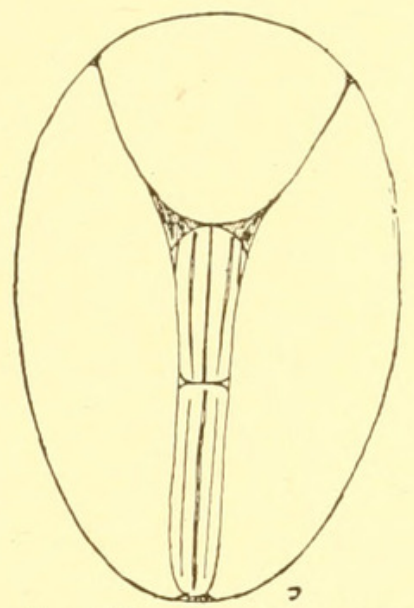

Fig. 121.-PHTHIRACARUS SP., CLOSED UP; VENTRAI. VIEW. at the tip of the tibia is often much longer than the others. The tarsus is commonly more hairy than the other joints.

On the dorsum of the cephalothorax there are often narrow ridges or lamellæ; the position, shape and development of these being characteristic of each species. Generally there is an erect lamella each side, extending in a point (sometimes bifid) in front of the cephalothorax. Frequently there is a trans-lamella connecting the lateral lamellæ. There are also on the cephalothorax usually two pairs of bristles, the pair near and between the pseudostigmata are the superior bristles; the pair toward the tip and often at ends of the lamellæ are the inferior bristles. There is also a pair of smaller bristles at the apex of

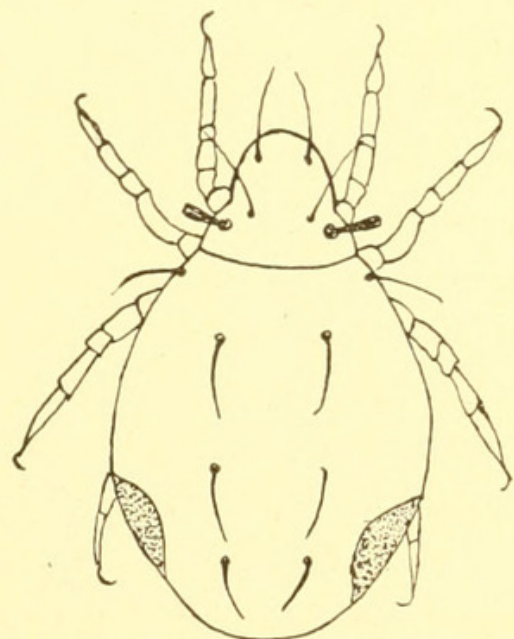

Fig. 123.-NYMPH OF A GALUMYA. the cephalothorax. Around the sides of the abdomen there is a line separating the dorsum from the venter. In the Hoplodermidx this line is often far down on the under side of the body. The dorsum of the abdomen is often devoid of hairs, but sometimes there are a few, usually arranged in rows. On the venter are two openings, the basal the genital one as usual. These openings are circular, elliptical, or rhomboidal, and are closed by folding doors opening outward, 
and hinged to the outer margins of the apertures. In many forms these apertures are very large and occupy the greater part of the venter, in other and more highly organized species the openings are much smaller and quite remote from each other.

The mouth-parts of the Oribatidæ

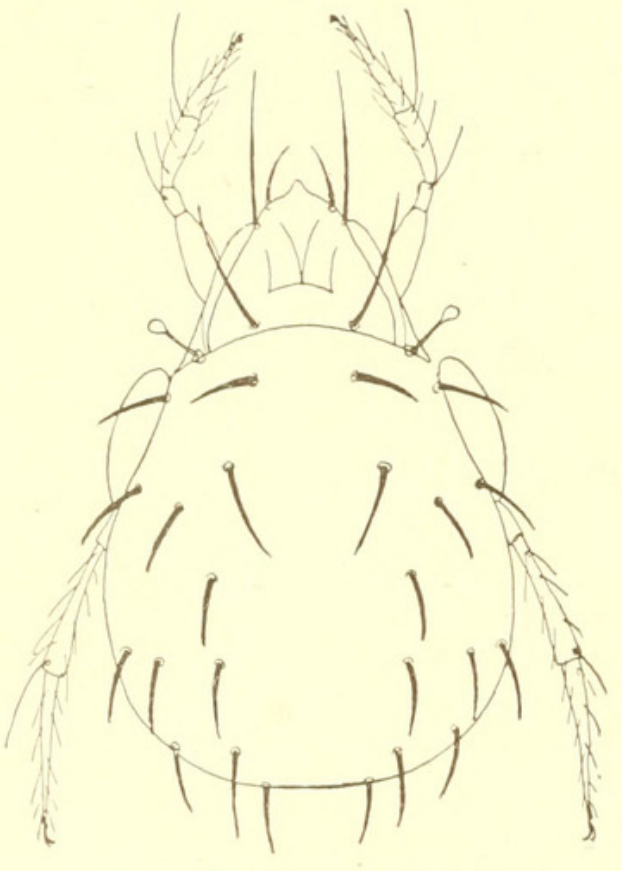

FIG, 124,-GALUMNA HUBBARDI. are obscure. The palpi are very small, five-jointed, and arise from the labium. They are usually in motion while the mite is walking. The mandibles are chelate in all save the genus Serrarius. The limbs of the chelæ are commonly toothed on the inner sides. In Serrarius the mandibles are elongated and rod-like, and there is no movable limb at tip; the sides are serrate, so that the mandibles act as a saw. The maxillæ have their basal joints united into one transverse piece, the labium, which partly and sometimes wholly closes the mouth-orifice. The maxillæ incline slightly toward each other; their tips are broad and toothed. The Oribatidæ deposit the eggs in crevices of wood, moss, fungi, or on the ground. The six-legged larva remains for a few weeks in this stage, when, by a molt, it becomes an eight-legged nymph. The nymph passes through three molts, increasing in size at each, the third molt bringing it to

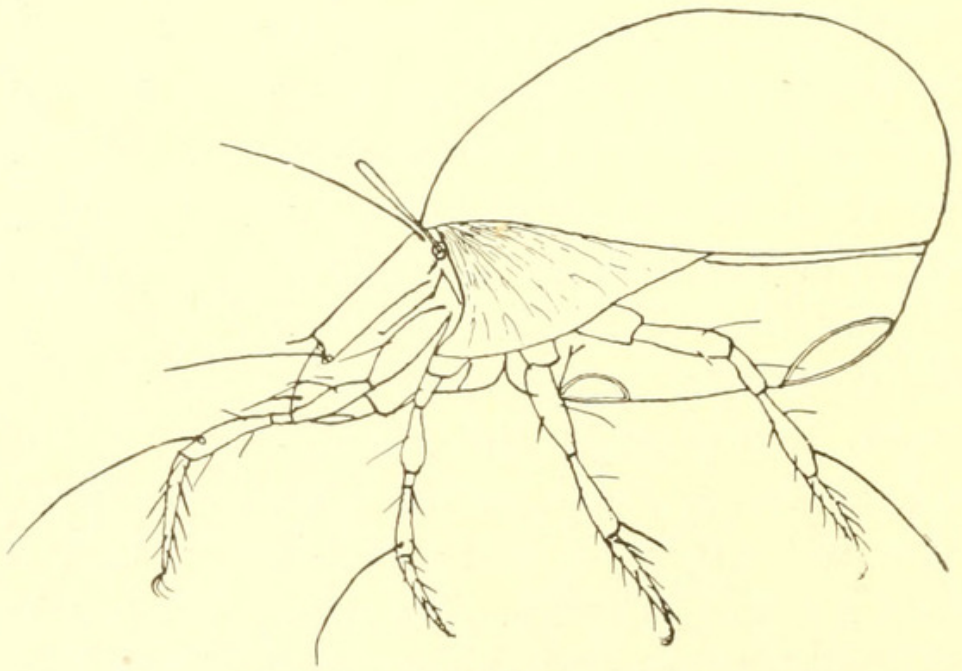

Fig. 125.-Oribatella armata.

the adult condition. In some cases the eggs are not deposited, but ripen in the body of the parent mite, the mother then dies and dries up, her old shell remaining as a protection for the eggs till they hatch. In some species the egg has a hard shell; the growth of the embryo splits the shell and shows the pale vitelline membrane as a white band around the egg. 
The larvæ and nymphs are always monodactyle - that is, with one claw to tarsus. Their skin is soft and

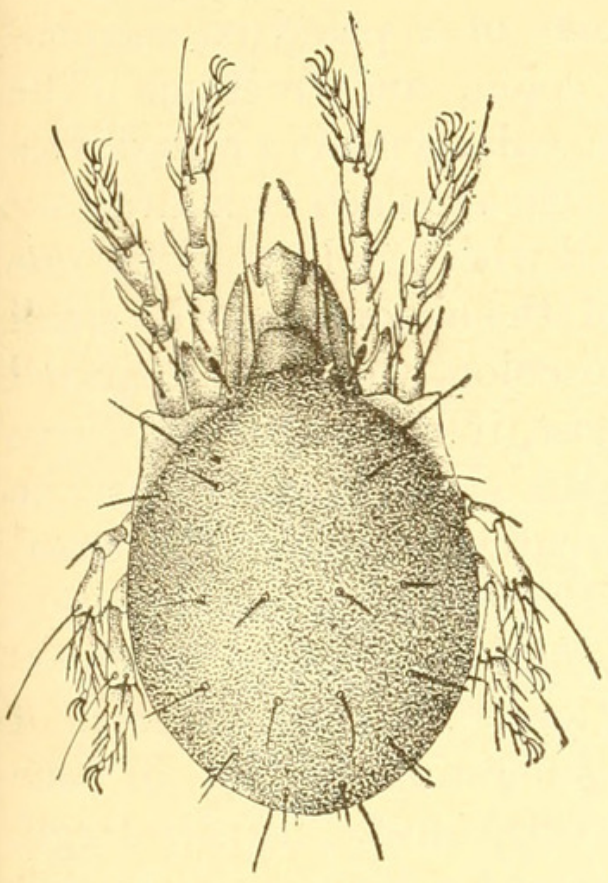

Fig. 126.-ORibatella SP. (PERgaNde). flexible. There are few creatures more bizarre or remarkable than the nymphs of certain Oribatidæ. 'Some bear upon the back concentric rings of beautifully

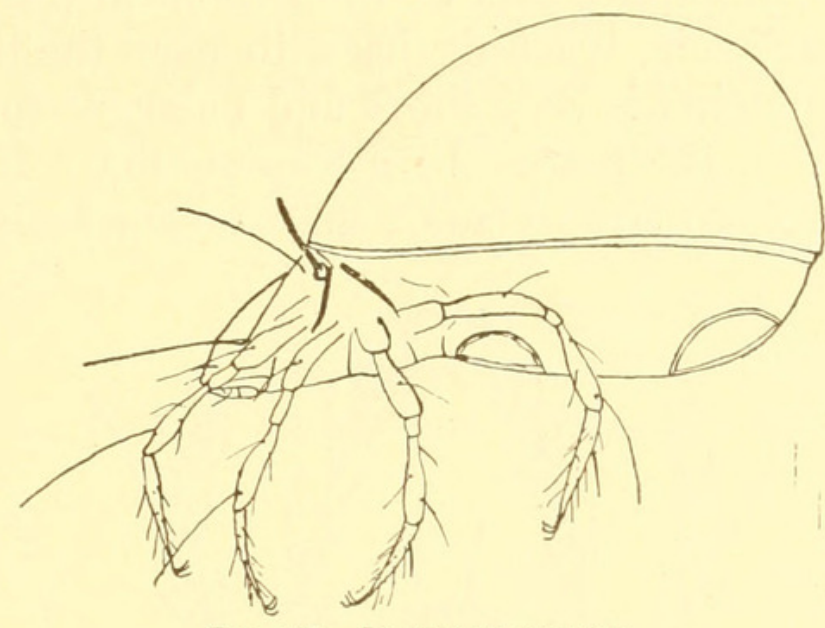

Fig, 127,-LIACARUS NITIDUS.

iridescent, membraneous, fan-shaped scales. Others carry a collection of their molted skins, eggshells, bits of dirt, moss, etc. - a veritable peddler's pack of trash. Many species have rows of serrate hairs on their backs. The skin of the back of many nymphs is wrinkled so as to allow for growth. Many of these nymphs were described by early writers on Acari as distinct species.

When a nymph is about to become an imago, it seeks some sheltered spot and fixing its legs firmly in the substance upon which it rests, it gradually becomes inert and apparently dead. It remains in this condition about ten days. When about to transform to the adult the skin splits behind and shows the imago beneath; this split increases without any perceptible movement of the mite, until it is quite large, when the mite begins to back out of its old shell. It may then be seen that the legs of the adult are not with-

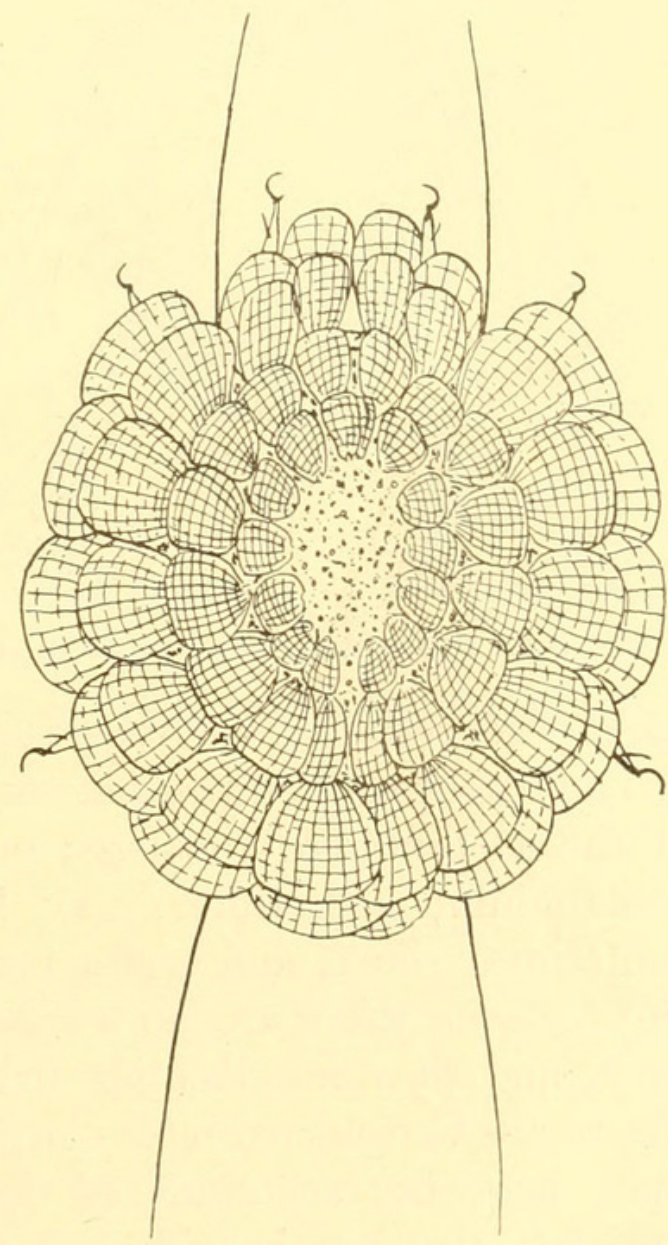

Fig. 128.-LIACARUS SP., NYMPH. drawn from the legs of the nymph, but were folded beneath the adult. 
The internal anatomy of the Oribatide is quite well known, having been investigated by Nicolet and later and more thoroughly by Michael. The alimentary canal is composed of a pharynx, cosophagus, stomach or ventriculus, intestine, colon, and rectum. The cesophagus has, near its posterior part, an enlargement or ingluvies of varying size, according to the species. The stomach is a large sac in the upper part of the abdomen, provided with two large caca, one each side, reaching back to near the tip of the abdomen. The small intestine is very short and enlarges to the colon, which is separated from the rectum by a constriction. In most, if not all, forms there are two large glands, the preventricular glands, which open into the

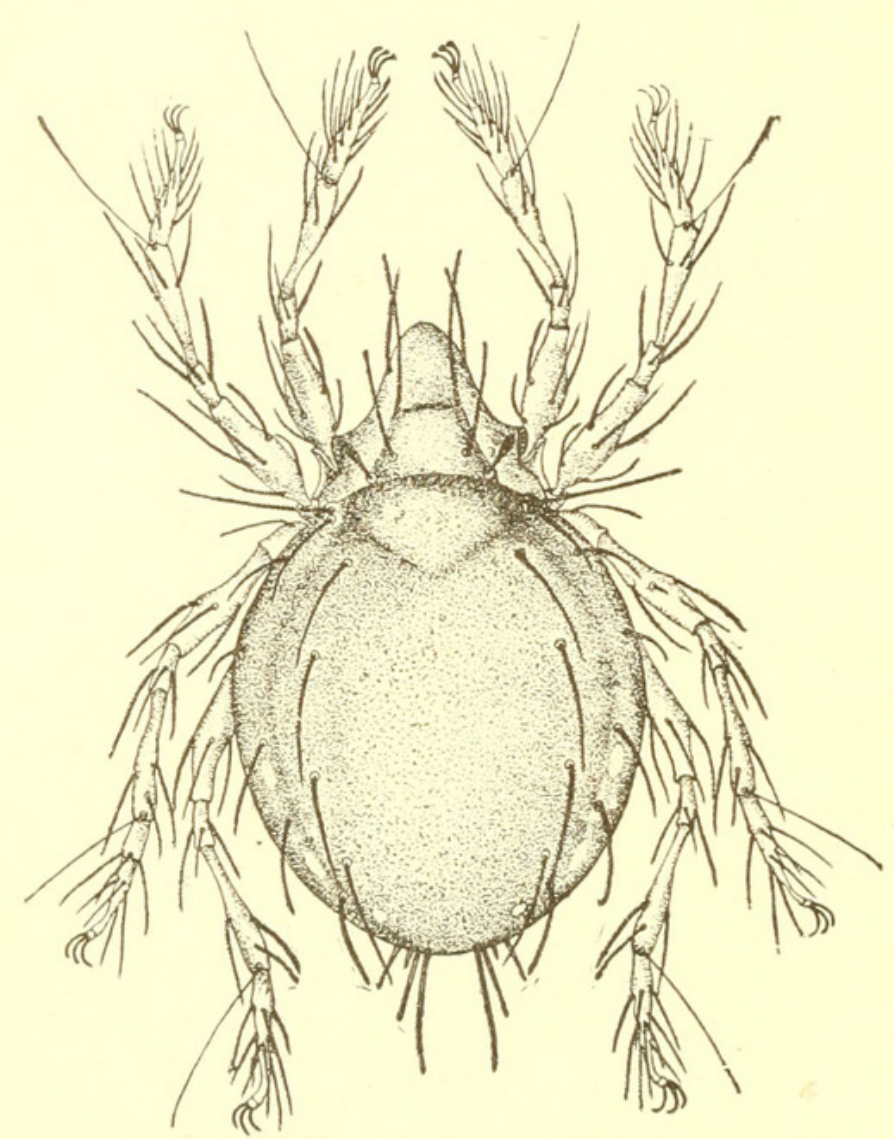

Fig. 129.-EREMAt's PILOSUS (PERGANDE). ventriculus near the cæca. They are supposed to secrete some fluid useful in digestion. The male organs of generation consist of one central testis, usually large, two vasa deferentia, uniting into a ductus ejaculatorius, which opens through an extensile penis. In the female there is a median ovary (sometimes showing traces of division) opening into two oviducts which unite in a vagina; the latter opens through a protrusible ovipositor. It is possible that the ovary is connected by two fine tubes to an aperture near the anus, and that this is the bursa copulatrix. Coition, however, has not been observed, so it is not certain that the male does not use the vagina.

The tracheæ when present vary much in shape and size. They open at the acetabula of the legs; one or two tracheæ proceed from each acetabulum; sometimes very long, and wind about in the body; sometimes short, and again may be enlarged to form air sacs. In Hoploderma there are no tracheæ, and in Nothms they are rudimentary, and they are lacking in the larve and nymphs of all forms. There are various excretory organs; one pair, the supracoxal glands, open near the acetabula of the second legs; others, the expulsory vesicles open on the sides of the abdomen. The Oribatidæ have a delicate sense of touch, which resides apparently in the long hairs or setæ upon the legs, particularly a very long hair on the tibia. They 
have no eyes, yet have a quick appreciation of light and darkness, and prefer the latter. It is quite possible that the pseudo-stigmata

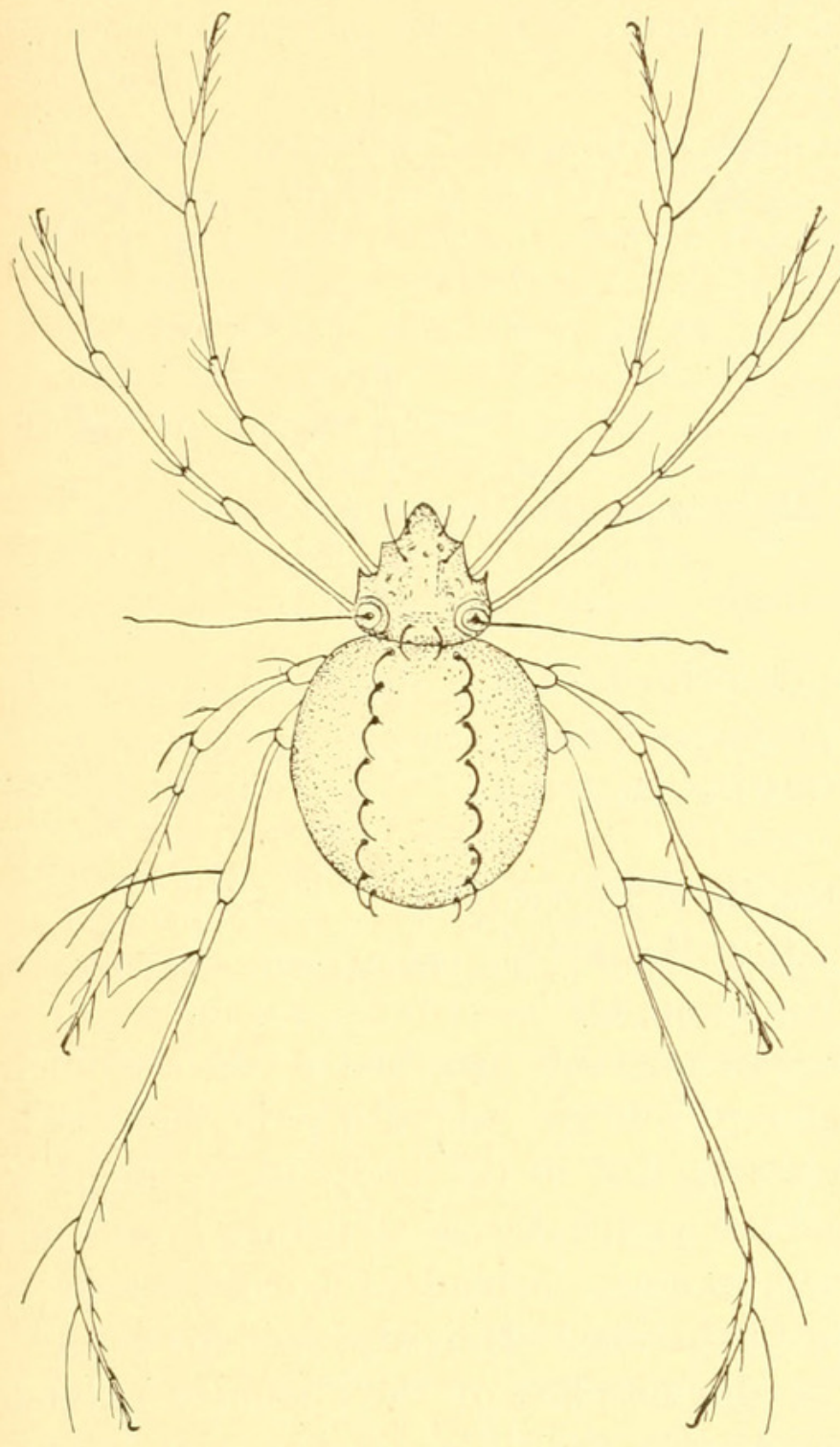

FIG. 130.-ORIBATA GRACIIIPES. are organs of hearing.

The food of the Oribatide is usually of vegetable nature, but a few species affect decaying animal matter; one of our common species is usually found on bones. Many feed on lichens and fungi, and some bore into decaying wood. Several kinds are found on the bark of living trees, and others under dead bark. Many species

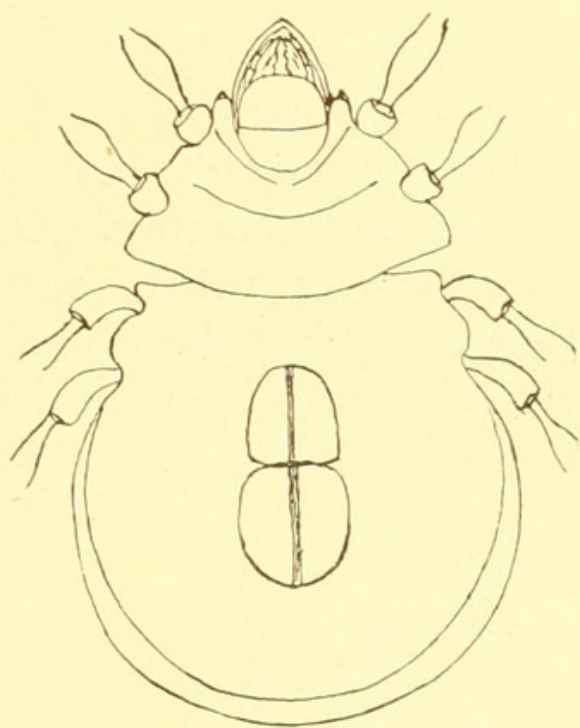

FIG. 131.-VENTER OF ORIBATA.

occur in moss, but do not necessarily feed upon it. Most species are slow in traveling, and often, when disturbed, feign death. Many of the adult mites carry their molted skins and other rubbish on their back.

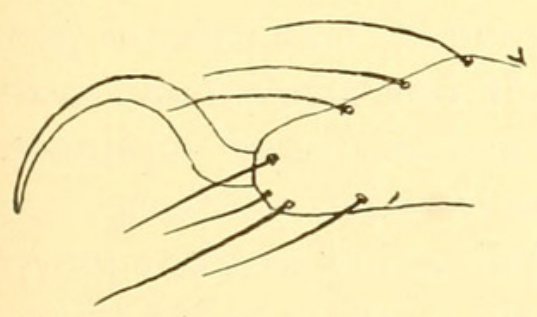

FIG. 132.-CLAW OF AN ORIBATA.

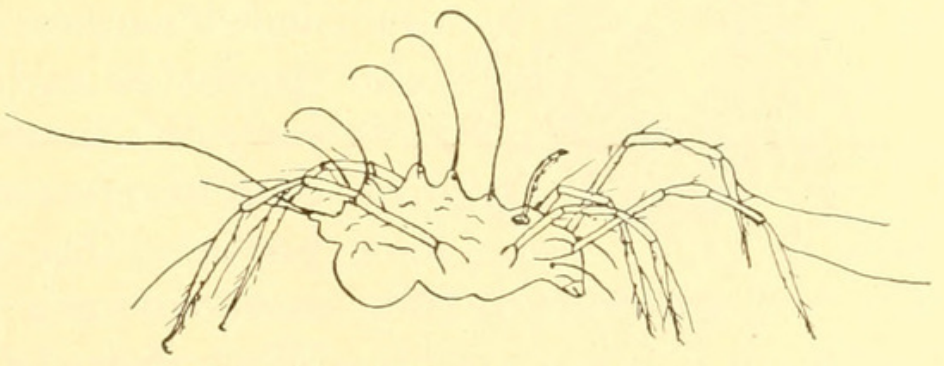

FIG. 133.-LARVA OF AN ORIBATA.

Practically none of the Oribatidx are of economic importance. A few have been recorded as damaging grass; but as a whole they prob- 
ably are slightly beneficial. There are doubtless 200 species of this family in the United States, but only about fifty or sixty, mainly from

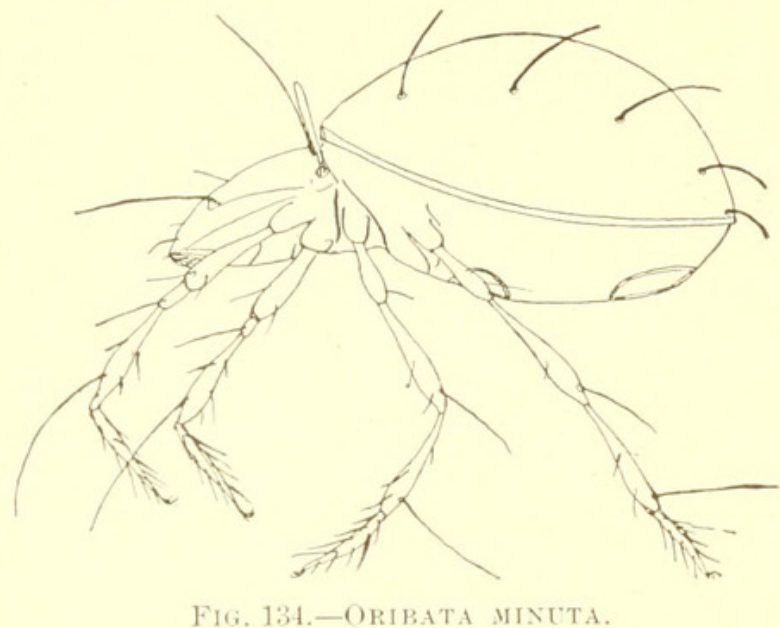

the Eastern States, have been described. On account of their minute size, obscure habits, and small economic value they are rot favorites with collectors.

The superfamily Oribatoidea includes two well-marked families. One, the Hoplodermidæ, are separated from the genuine Oribatidæe in having the cephalothorax movably attached to the abdomen. By this means the animal is able to roll up, concealing the legs. The legs of the Hoplodermide are attached to the body, close together,

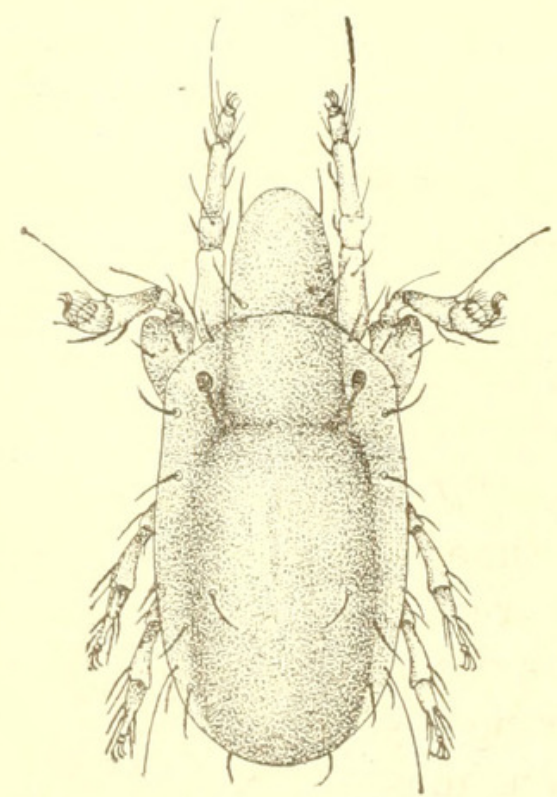

Fig, 136,-ORIPODA ELONGATA (PERGANDE). and the whole sternal structure is soft and membranous, instead of coriaceous as in the Oribatidæ. The palpi are four-jointed. The dorsal plate of the abdomen extends down upon the sides, so that the venter is very narrow and almost wholly occupied by the large genital and anal apertures. We have two genera of this family-Hoploderma, with one claw to tarsus, and Phthiracarus, with three claws to tarsus, and a narrower venter. We have a few species in each genus; Plithiracarus glabrate Say is one of our largest and most common forms, and is found on moist ground. The species of IToploderma are most common in decaying wood or moss. When disturbed they roll up, play "possum," and are then not easily discerned. One of the species described by Doctor Riley was supposed to feed on the Plylloxera, but such is not the case. 
In the true Oribatidx there are a great many genera, and there appears to be much doubt as to the proper names of several of them, owing to the work of old authors who had no idea of the rules of modern nomenclature. The forms, as far as known, can be grouped as follows:

1. Abdomen with wing-like expansions at the anterior sides $\ldots \ldots \ldots \ldots \ldots \ldots .2$ Abdomen without wing-like expansions......................... 6

2. Superior bristles spatulate; mandibles elongate................... Pelops Superior bristles not spatulate

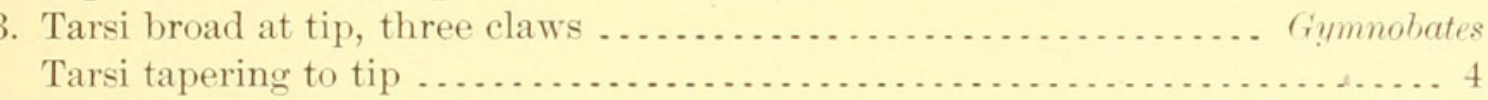

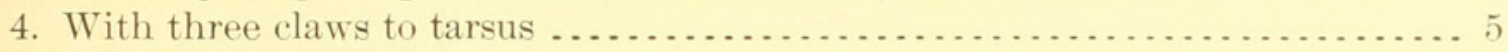

With but one claw to tarsus............................... Oribatodes

5. Cephalothorax with lamellæ large, and attached to cephalothorax for only part of their length.

Oribatella

Cephalothorax with smaller lamellæ, attached for nearly their whole length,

Galumna

6. Cephalothorax with lamellæ................................... 7

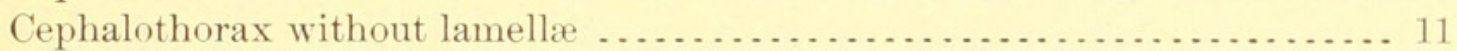

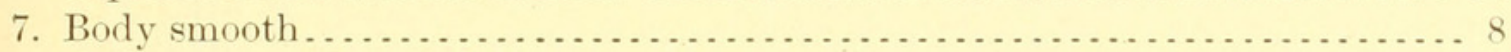

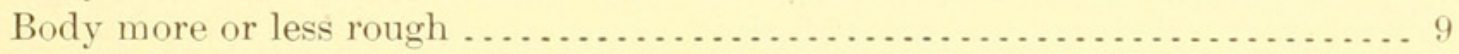

8. Legs II, III, and IV inserted under body ....................... Liacarus

Legs inserted more on side of body . . . . . . . . . . . . . . . . . . . Eremæus

9. Cephalothorax and abdomen plainly separated on dorsum . . . . . . . . . . . 10

Cephalothorax and abdomen more or less united ................ Scutovertex

10. Claws three; femora I and II not pedunculate.................. Notaspis

Claw one; femora I and II pedunculate ...................... Carabodes

11. Legs slender, longer than body . . . . . . . . . . . . . . . . . . . . . . . . 12

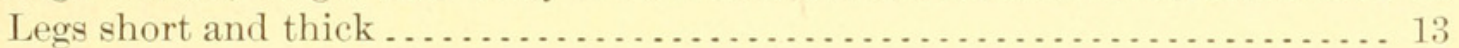

12. Claws three

Gymnodamæus

Claw one.

Oribata

13. Abdomen transversely segmented.

Hypochthonius

Abdomen not transversely segmented

14. Claw one; dorsum convex ..................................... Hermannia

Claws three ................................................. 15

15. Dorsum very convex, with concentric rings .................... Neoliodes

Dorsum quite flat, without concentric rings ...................... 16

16. Leg II with tectopedia; dorsum coriaceous; body elliptical ....... Cymberemxus

Leg II without tectopedia; dorsum softer; body more rectangular..... . Nothrus

Most of our common forms belong to either Galumna or Oribatella. They are usually shining black in color, sometimes with a pale spot at loase of abdomen, and rarely with hairs or bristles above. They have the anterior sides of the dorsal integument extended downward in a wing-like expansion. The shape of this "wing" is characteristic in each species. Many species can be sifted from moss. They at first remain quiescent, but after a few moments start to crawl away.

$G$. pratensis Banks may be swept from meadows in great numbers, and doubtless injures grass to some extent. O. aquatica Banks lives on aquatic plants, and can readily walk on the surface of stagnant water, yet there seems to be nothing peculiar in the structure of the 
tarsi. G. arbored Banks and G. affinis Banks occur on the bark of trees. G. hirsuta Banks is a pale yellowish form, with a bristly body, occurring in dry sandy places.

One of our common forms and one of the largest of the family, being fully one millimeter long, is Liacarus nitidus Banks. It occurs on the ground under pieces of wood, bark, stones, and fallen leaves. A species of Eremzus, E. pilosus Banks, is common in the crevices of bark of living trees. There are four rows of bristles on the abdomen. A species of Scutovertex, S. marimus Banks, is not uncommon on rocks between tide

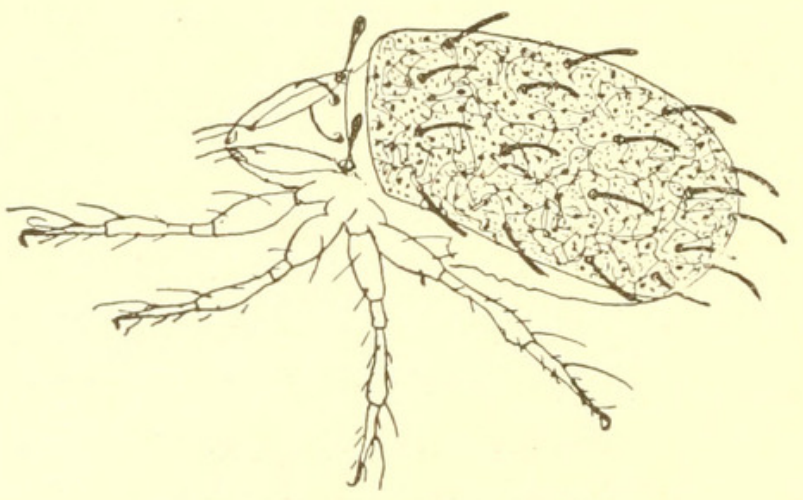

FIG. 137.-CARABODES BREVIS.

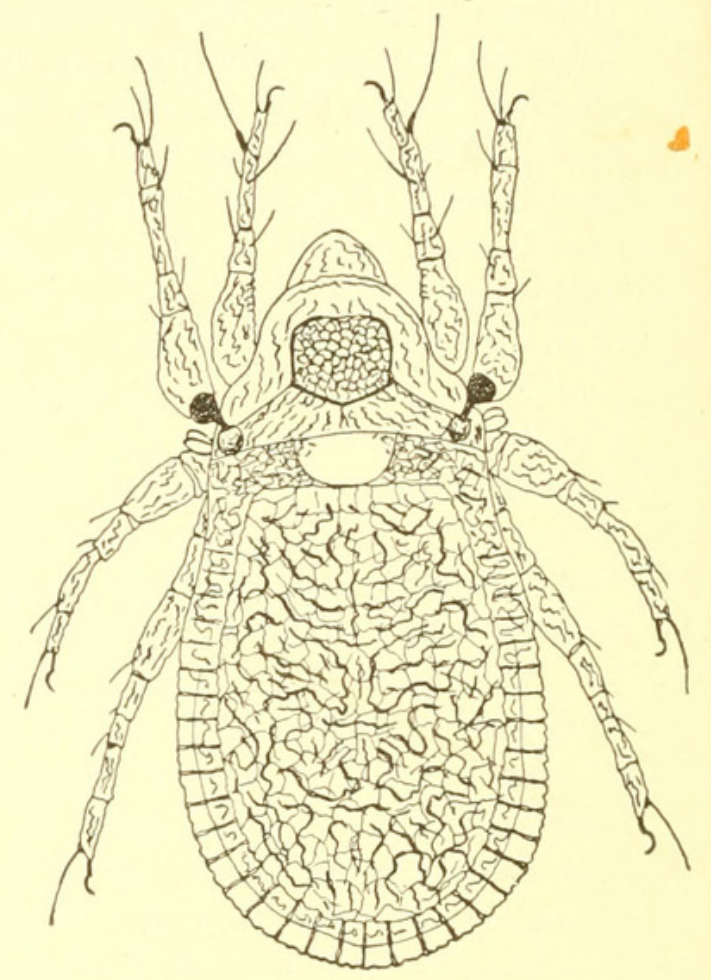

Fig. 138.-CYMBEREMAUS MaRgiNalis.

marks on the Atlantic seashore. It appears to lack the pseudostigmatic organs and is otherwise peculiar. Notaspis punctulatus Banks is a pretty species, with a deeply pitted dorsum, and is found in decaying fungi.

Of Carabodes we have several species, some of which are found in fungi. Our most abundant species, C. niger Banks, which occurs in

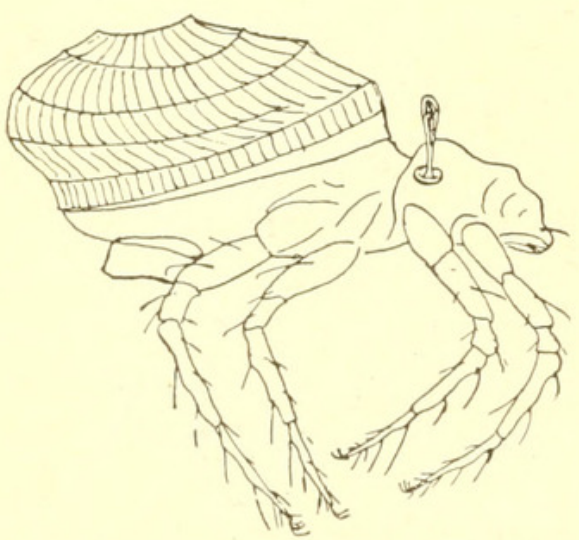

FIG. 139.-NEOLIODES CONCENTRICUS. fungi, has four rows of spatulate hairs on dorsum. $C$. oblonga Banks was found boring under the bark of a stump, and it looks much like a tiny scolytid beetle. A species of Oribata, O. minuta Banks, occurs in moss and on decaying animal substances. It is pale yellowish-brown in color and appears to be widely distributed. The largest Oribatid we have is Neoliodes concentricus Say, a black species with concentric rings on its elevated abdomen.

It occurs in crevices of bark of living trees throughout the Eastern States, and also in Europe. Our one species of Cymberemzus, C. marginalis Banks, occurs under lichens on the bark of trees in the Eastern States.

We have various species of Wothrus. They are very rough-looking 
creatures, with a squarish body and short, rough legs. I. truncatus Banks occurs in sphagnum moss and on the ground in wet fields. N.excisus Banks occurs on the bark of spruce trees, where it is much protected by its color. Another species, $\bar{V}$. simplex Banks, was found among lichens on dry rocks. $\quad$. rugulosus Banks is a common form under loose bark; it can scarcely be distinguished from the bits of dirt among which it lives.

The genus Hypochthonius has not been found in this country. It has a soft skin, which usually shows traces of segmentation. They occur in moss and damp places. The genus Pelops, closely related to Galumna, is likewise not yet known in this country.

As an appendix to the Oribatoidea may be added the genus Nicoletiella Canestrini, a genus represented by two European and one Central American species. It differs from the other Oribatidx in the

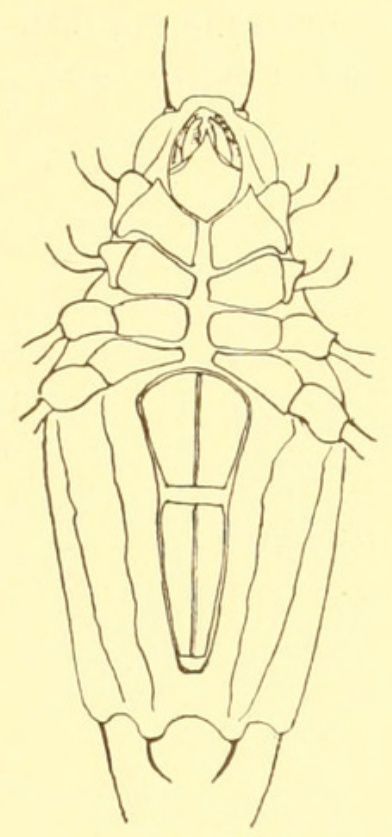

Fig. 140.-VENTER OF A NOTHRUS. large and prominent chelate mandibles, by the indefinite pseudostigmatic organs, the complete union of cephalothorax and abdomen, and

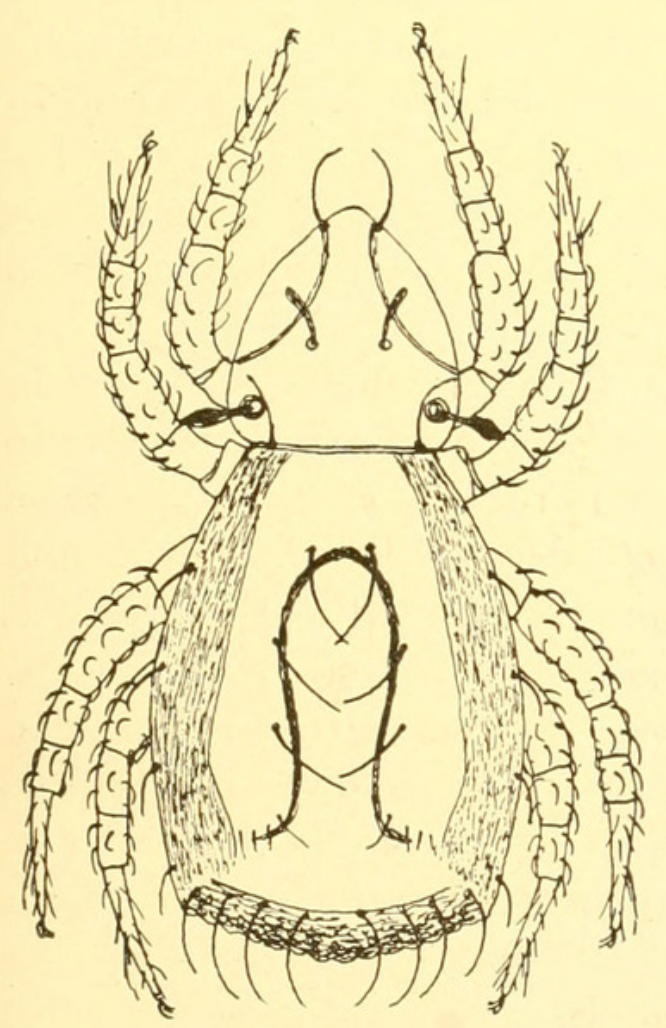

FIG. 141.-NOTHRUS BANKSI. by having but one large aperture on the venter near its tip, which includes both anal and genital openings. The coxæ are all close together, and touch on the median line. The palpi are very short and simple. Legs I and II end in two claws; legs III and IV end in three claws. The species occur on

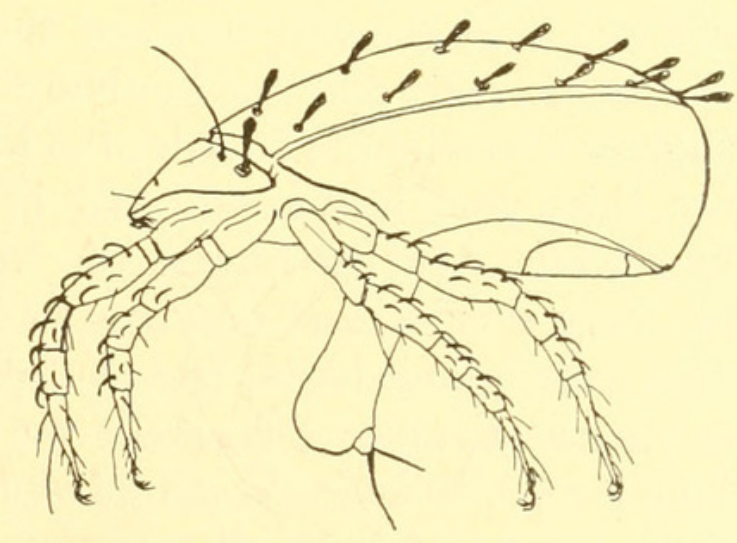

Fig. 142.-Nothrus TRUNCATUS.

the ground, under stones, dead leaves, and in moss. They have much resemblance to some Gamasidæ. 


\section{Family TARSONEMIDA.}

This is a small family, but of much biological and economical interest. They are soft-bodied mites, and in some ways resemble the Tyroglyphidæ, but the females dif-

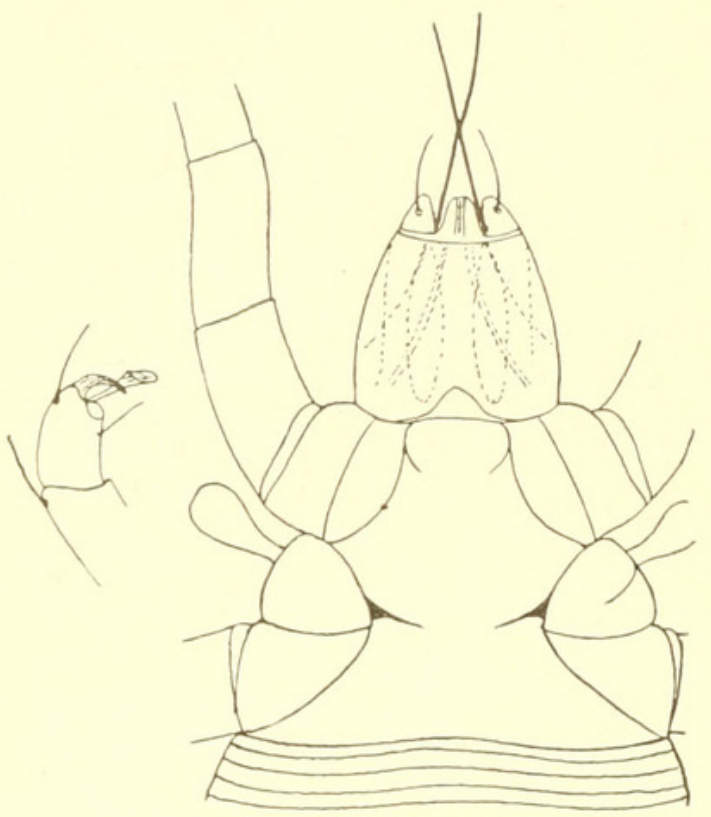

FIG, 143.-BEAK AND CLAW OF PEDICULOIDES. fer from them, as well as from all other acarians, in having between legs I and II a prominent clavate organ of uncertain use. The mouthparts are formed for sucking, and the mandibles are very slender and needle-like. The palpi are minute and barely visible. There are tracheæ which open on the ventral surface near the base of the rostrum. The legs are short and composed of five or six joints; the anterior tarsi terminate in one claw, the others usually have two claws and often a sucker. The posterior pairs of legs are quite remote from the anterior pairs; in the males of Tarsonemus they are almost at the tip of the body. In some species the abdomen shows traces of segmentation by the presence of a few transverse lines on the dorsum. The anal opening is at the end of the body; the genital opening in Tarsonemus is a small, elongate aperture near the hind coxæ. The body and legs are provided with a few simple hairs. In several genera of the family, notably in Tarsonemus, there is a marked difference in the structure of the sexes. In the male Tarsonemus the body is much shorter than in the female, the hind legs are thick and heavy, and end in a very large claw. In the female the hind legs are very slender and delicate, and terminate in two long hairs, one of them often as long as the entire leg. In the mature female of Pediculoides the abdomen becomes enormously swollen so that it is 20 to 100 times greater than the rest of the body; the whole animal appearing as a

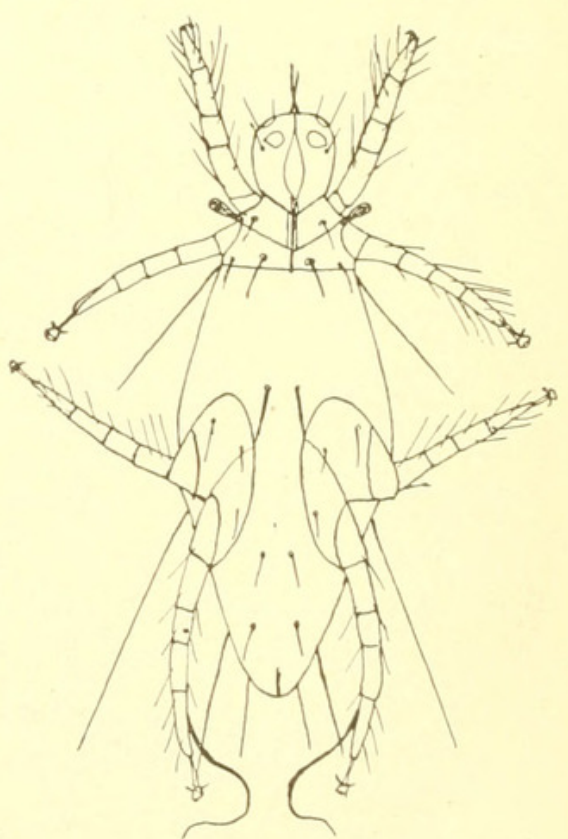

Fig. 144.-PEdiculoides ventricosus, FEMALE.

white spherical grain, with a tiny sear on one side. The male of Pediculoides has almost no abdomen at all; the body being very short, and angulate behind. The head in this genus is almost a distinct 
portion of the body. Brucker has studied the anatomy of Pediculoides; there is a large stomach, connecting to the mouth by a slender cesophagus; to the latter is attached a blind pharynx. He found no anus (but I believe one exists in Tarsonemus) the intestine ending blindly near tip of body. The genital opening is at tip of the body; above it is a short spermatheca. In the females there are a pair of air reservoirs in the front part of body; behind them are tufts of tracheæ, which, when the female becomes swollen by eggs, extend into the swollen part.

The Tarsonemidæ have not long held any one position in the system of Acarina. They have been associated with Oribatide and Cheyletidx, and Berlese has recently elevated the family into one of the principal groups of the order. The dimorphism

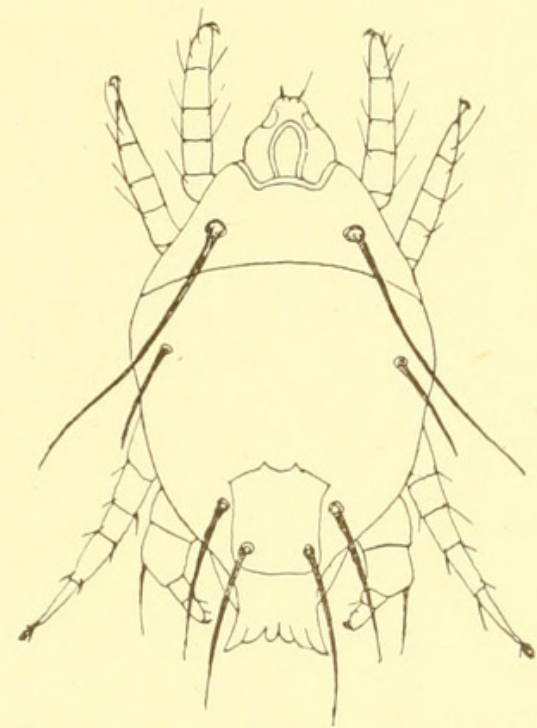

Fig. 145.-PEDICULOIDES VENTRICOSUS, MALE, in certain forms seems to suggest affinity to the Tyroglyphidæ.

The family has been divided into two groups.

Hind legs of female ending in claw and sucker as in other pairs ........ Pediculoidinx Hind legs of female end in long hairs

Tarsoneminx

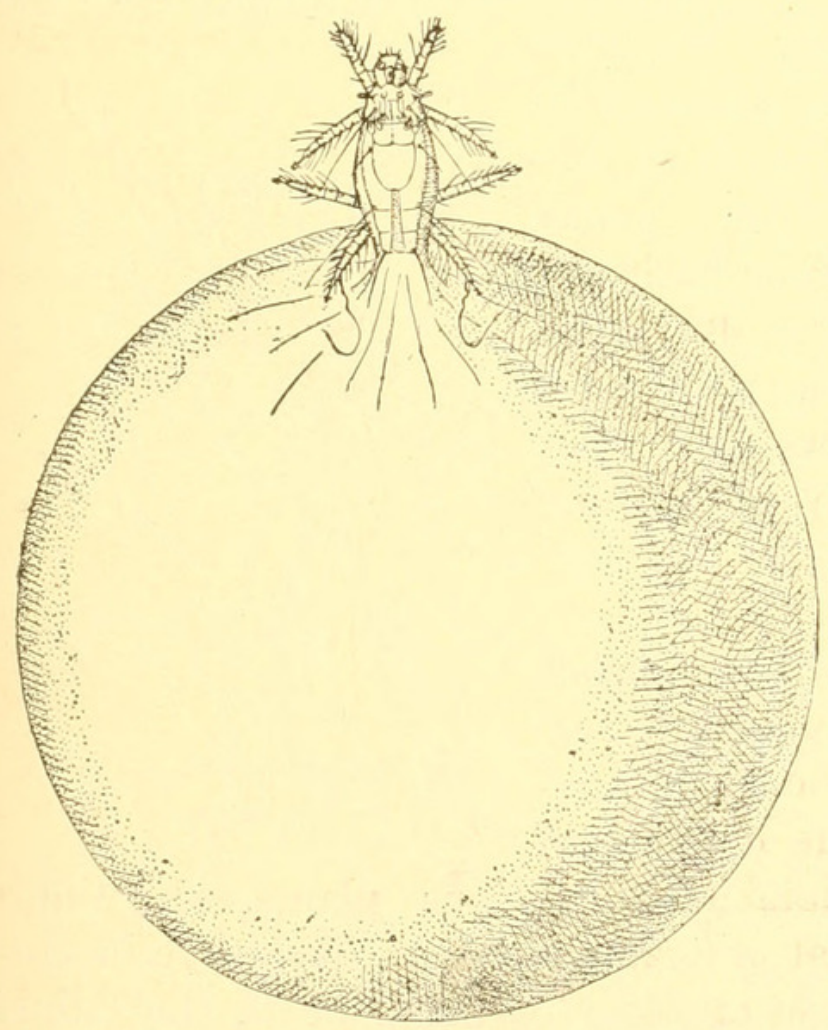

Fig. 146.-PEDiculoides VeNtricosus, gra Vid FEMALE (BUREAU OF ENTOMOLOGY).

In the first subfamily are two or three genera, the most prominent is Pediculoides.

In 1850 Newport gave the name Heteropus ventricosus to a mite found on the larva of a wasp. Since then the same mite has been found on various insects, both alive and dead. The generic name was preoccupied, and was changed to Pediculoides by TargioniTozzetti in 1875. The species has become of much economic importance since it is frequently parasitic upon injurious insects. The abdomen of the pregnant female swells to an enormous size, this being due to the development of the eggs. These not only hatch within the parent, but obtain their entire development there, and issue as sexually mature males and females. These may wander about for a time on the body of the mother and soon pair. 
The body of the male ends in a broad sucker, wherein is situated the penis. The tip of the female is grasped by this sucker. P. ventricosus occurs commonly in this country, and another species has been

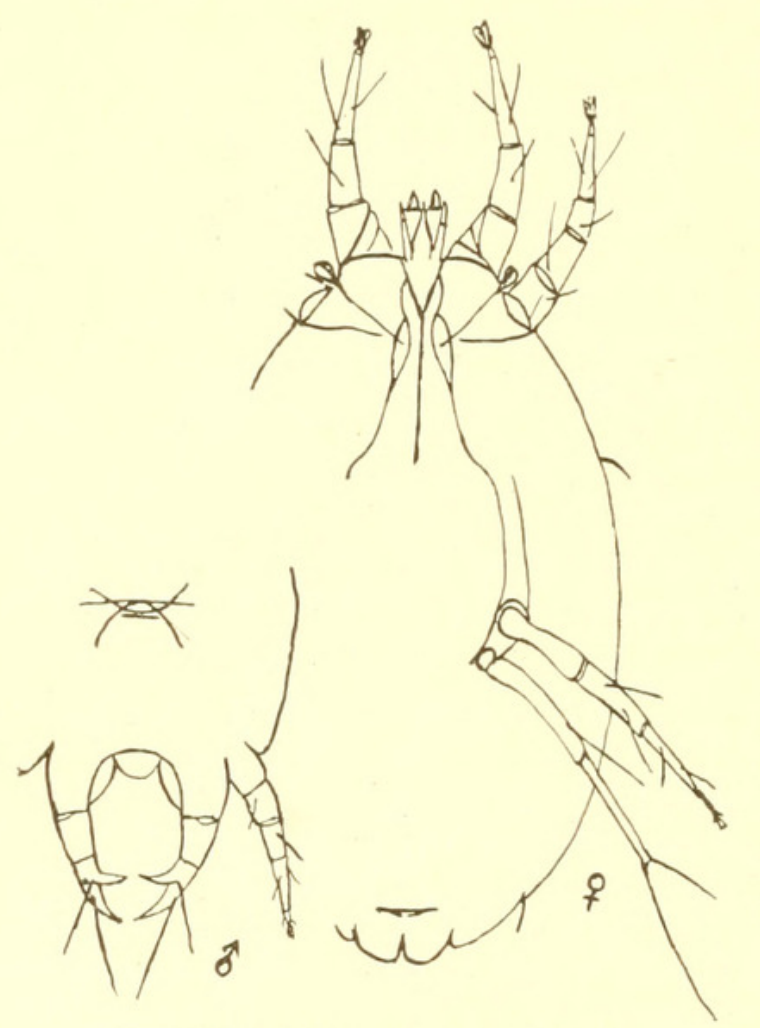

Fig, 147.-TARSONEMUS PALLIDUS.

found on the larve of scolytid beetles. Professor Herrera, the Mexican entomologist, has endeavored to breed a Mexican species to kill the grubs of the cotton-boll weevil.

Several other species have been assigned to this genus which feed on grain and grasses. One would suspect that they would fall in a separate genus, for which the name Siteroptes Amerling is available. One is $P$. tritici, found in wheat heads; another is $P$. graminis which Reuter has described as partly responsible for "silver-top" in certain grasses.

Pigmeophorus is closely allied to Pediculoides. It has a migratorial form, which in one case was found on a mole, and in another on a fly. We have observed a species in this country attached in some numbers to a fly-Platycnemis imper-

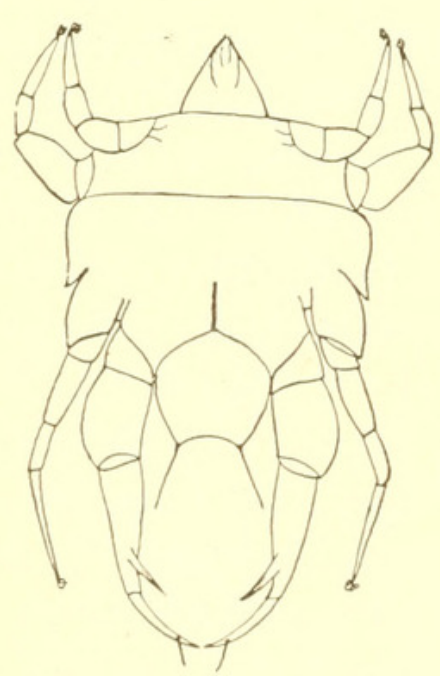

FIG. 149.-TARSONEMUS IATUS, MALE.

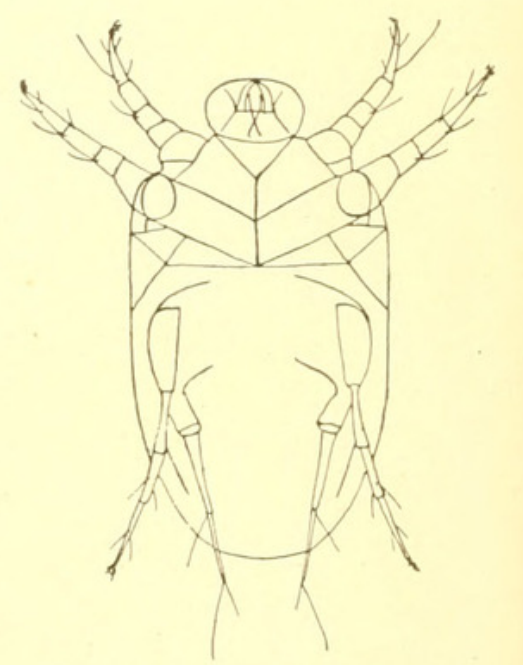

FIG. 148. - TARSONEMUS IATUS, FEMALE. pes. The species of Tarsonemus affect various plants, sometimes producing galls upon them. They live in colonies upon the leaf or stem, or in the culms of grasses. One species, T. oryzx, infests rice in Italy; another, T. culmicola, produces "silver-top" in certain grasses of Finland; a similar form produces the same appearance in some grasses of New Mexico. One grass-stem may contain several million mites. Another species does considerable damage to tea in Ceylon. Tryon has 
described a species, T. anasæ, as injuring pineapples in Australia. I have described one, $T$. latus, which causes galls on the main shoots of mango plants. Another species, T. pallidus, has been found on various greenhouse plants in this country. Karpelles described a species, T. intectus (apparently identical with the Chrithoptes momunguiculosus of Geber), as attacking men in the Danube region of Hungary and Russia. The men had been handling barley and the mites spread from this to the hands, where they caused an irritating inflammation of the skin so intense as to force the men to leave their work. Michael has recorded a species, $T$. bancrofti, as the cause of serious damage to sugar cane in Queensland and also in Barbados. T. canestrinii produces small, rounded galls on several European grasses; T. spirifex forms elongate swellings on oats. But few remedies have been proposed for these mites; a mixture of powdered sulphur in soap and water has been

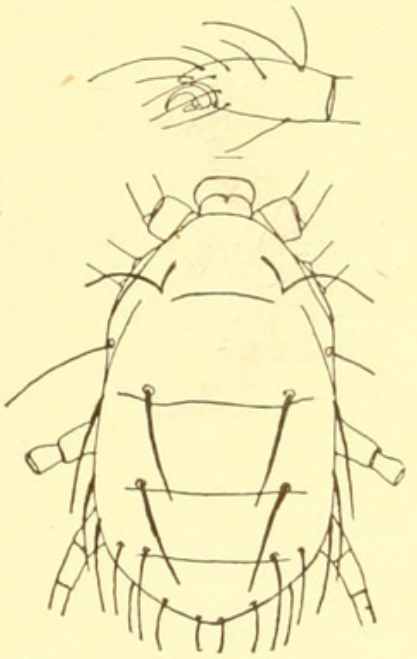

Fig. 150. - PigMEOPHORUS AMERICANUS, FROM ABOVE, AND TARSUS ENLARGED. suggested for the one on sugar cane. Probably the remedies for "red-spider" will be found applicable to them.

The curious genus, Disparipes, has a migratorial nymphal stage much like the Hypopus of the Tyroglyphidæ. This stage has been found on

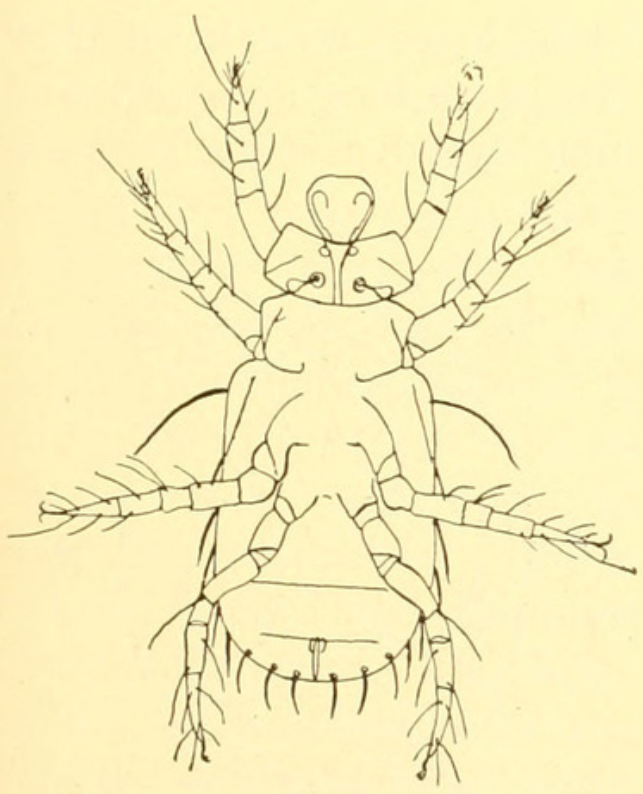

Fig. 151.-PIGMEOPHORUS AMERICANUS, FROM BELOW.

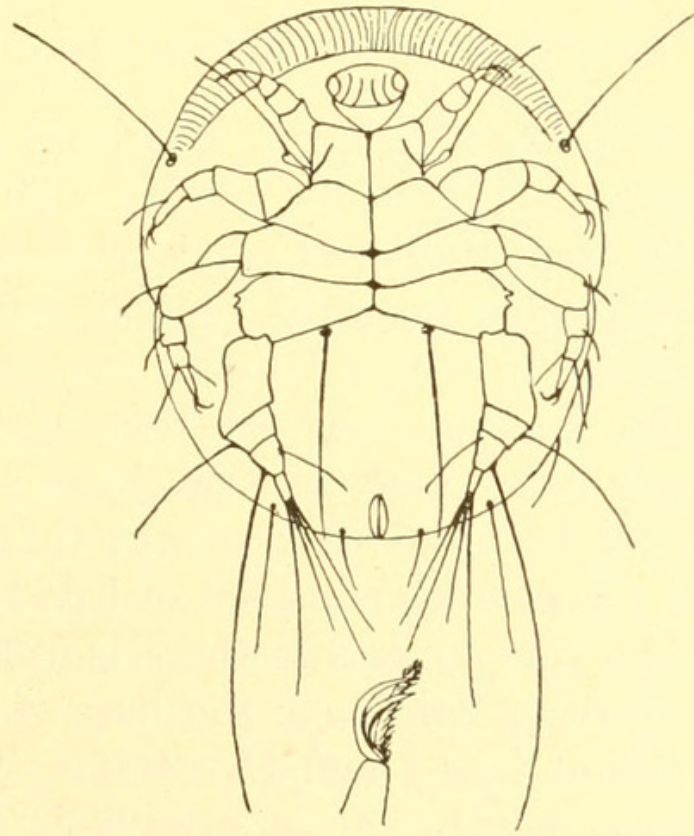

FIG. 152.-DISPARIPES AMERICANUS, FROM BELOW, AND CLAW.

bumblebees and ants. The adults occur on plants. I have seen specimens of an American species taken from a bee of the genus Halictus. Berlese has recently described a number of species taken from ants, and proposes to divide the genus into three groups, the two new ones being Diversipes and Imparipes; the characters, however, are very slight. 


\section{Family TYROGLYPHIDA.}

The Tyroglyphide (Sarcoptides détricoles of Mégnin) are not a large family of mites, but many of them are of considerable economic

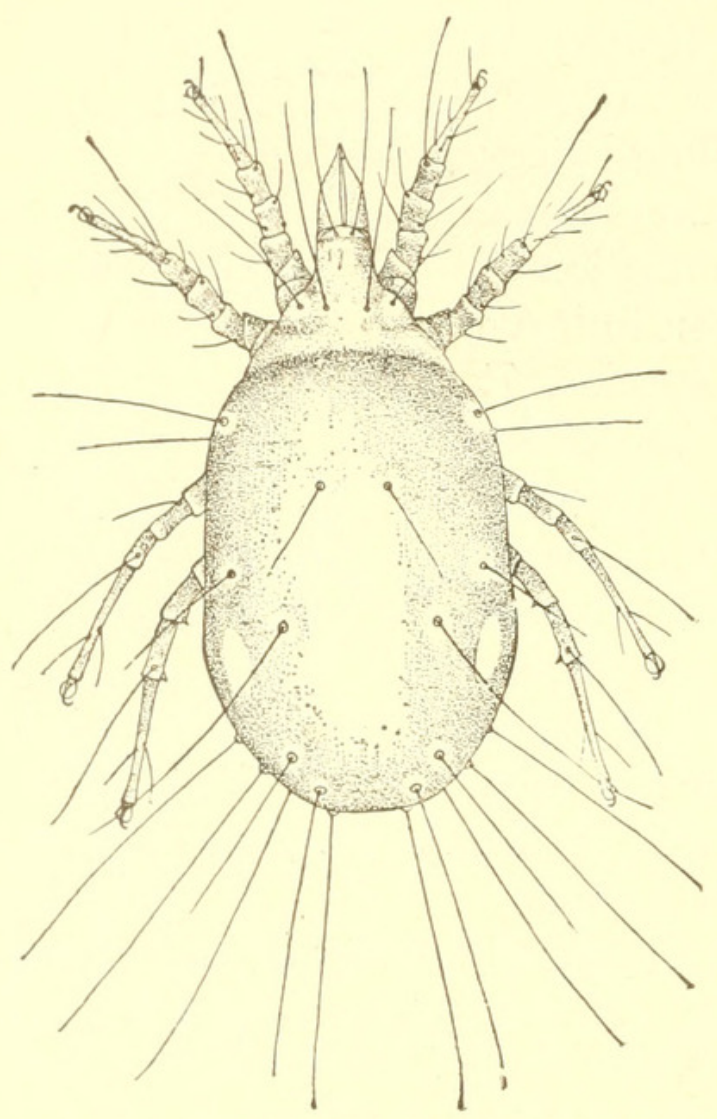

FIG. 153.-TYRogLYPHUS SP. (PERGANDE). importance, since several of them affect stored foods and the roots and bulbs of living plants. They have been known to naturaiists from the time of Linnæus. In the adult condition they are usually free, but during one stage of their life, known as the bypopial, they are attached to various insects and sometimes small mammals. This hypopial stage, or hypopus, is a migratorial condition; the mite during this period takes no food, so it is not a true parasite. However, in some cases where they occur in enormous numbers they may injure the insect, owing to their weight or position.

The Tyroglyphidæ are pale-colored, soft-bodied mites, devoid of tracheæ, usually with prominent chelate mandibles, small palpi, moderately long legs, ending in one claw and often a sucker. The body is about twice as long as broad, and broadest behind the middle. There is commonly a distinction between the cephalothorax and abdomen. There are no eyes (unless certain organs in a few Hypopi are eyes). The dorsum bears a few, mostly long hairs, and the legs have scattered hairs. One hair near the end of the penultimate joint of legs I and II is very long, and there is usually a clavate hair near the base of the tarsi of legs I and II. It may be a sense organ. It is always in this position although authors sometimes figure it as arising from the preceding joint. On the venter are the usual apertures. The genital is usually elongate, and situate between

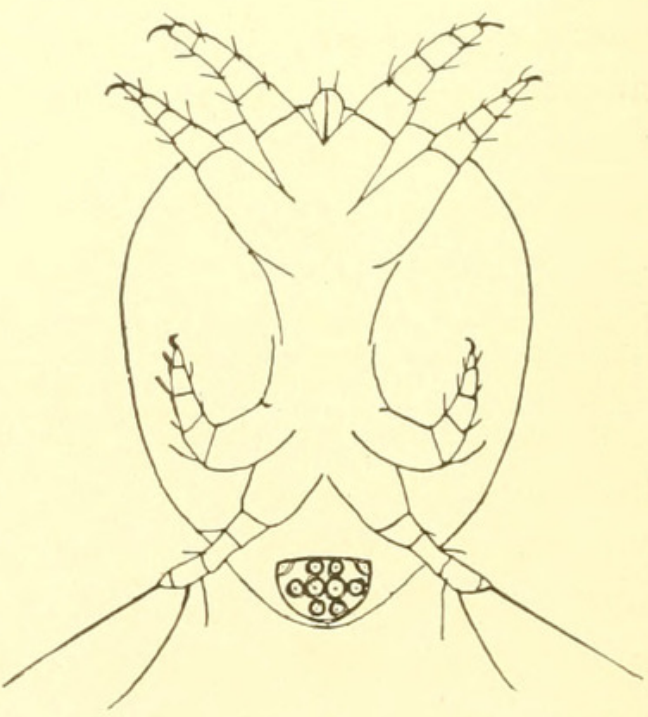

Fig. 154.-HYPOPUS OF A TYROGLYPHUS, FroM BELOW.

the hind coxæ; there are often two $U$-shaped marks each side of it, known as the genital suckers. The anal opening is usually much 
before the tip; it is often but an elongate slit, with a sucking-disk each side. In Glyciphagus the openings are much larger, and the genital sometimes occupies the entire area between the coxæ.

The internal anatomy of the Tyroglyphidæ has been carefully studied by Nalepa and Michael. The digestive system is of the usual type; the ventriculus is very large, with two short cœea, the colon is globose, the rectum very large, and opens close to tip of body. Behind the anus is a small opening-the copulative aperture. In Glyciphagus the bursa copulatrix projects externally in a small cone. So in the Tyroglyphidæ, as in the Analgesidæ, copulation is not performed through the vulva, but by this special opening. This opening leads to a receptaculum seminis, which connects by a small duct to the ovaries. The nervous system is chiefly concentrated in the very large "brain" which surrounds the œsophagus. The most powerful muscles of the mite are those attached to the mandibles, the legs, and the stomach.

As a rule there is little difference in size between the sexes, but Michael has described one form with the male not half as large as the female. In several cases there are well-marked secondary sexual characters, such as the enlargment of the first or third pair of legs in the male.

The transformations of the Tyroglyphidæ are among the most marvelous of the animal kingdom. All Tyroglyphidæ (except Carpoglyphus) appear to lay eggs, sometimes of large size. The young on hatching are six-legged, and, molting,

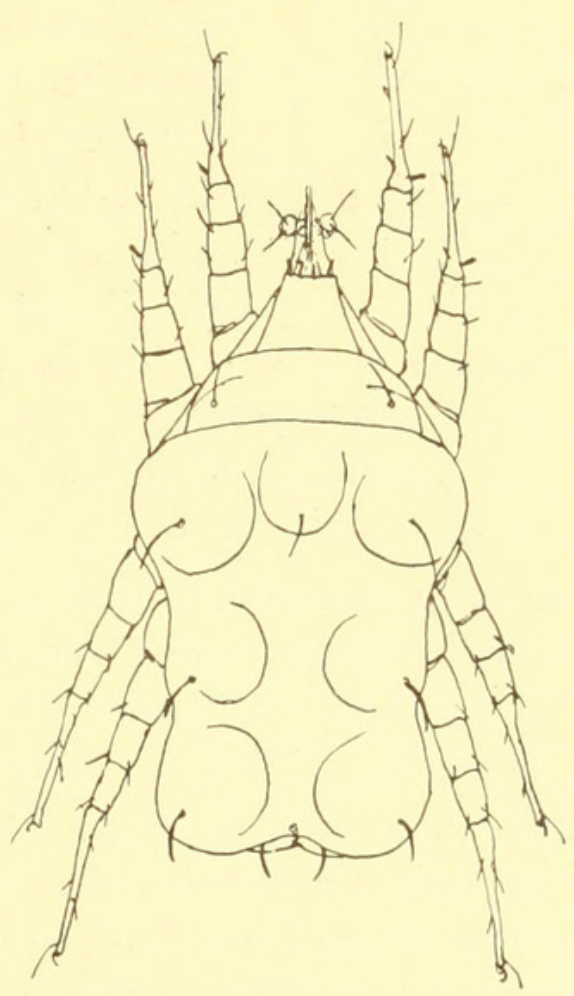

Fig. 155.-HistiostomA AMERICANA. obtain two more. Thenceforward their life-history may take the simple and direct path to the adult condition, but often it passes through what is called a Iypopus. This Hypopus is very different from the creature from which it has developed-the octopod nymph. Its body is hard and chitinous; there is no mouth-orifice and no distinct mouth-parts. The legs are short and ill adapted to walking. On the ventral surface of the body near the tip is an area distinct from the general surface and provided with several circular marks or sucking disks. By means of these sucking disks the Hypopus attaches itself to an insect or other creature and is transported to some other locality, where it may find a suitable breeding place. The Hypopus is thus a stage in the life of Tyroglyphus for the purpose of migration. The Ilypopus, on finding a suitable locality, molts into an octopod nymph, which will feed and develop into an adult mite. The causes 
that will induce a nymph to transform to a Iypopus are not known. Mégnin supposed that the dryness of the air or the scarcity of food were necessary causes. But Michael has shown that Hypopi are developed in the absence of these conditions, and that the Hypopus is the natural and normal means of distributing the species.

In the early days of the science of acarology this connection was unknown; therefore Hypopus stood for a separate

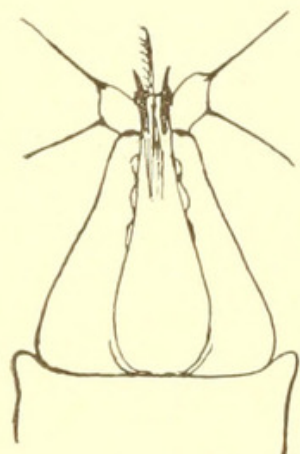

FIG, 156.-BEAK OF HISTIOSTOMA A ERICANA. genus, allied more to Gamasus than to Tyroglyphus. Dujardin in 1850 concluded that Hypopus was the pupal stage of Gamasidæ. As investigation proceeded Hypopus was so frequently found in association with Tyroglyphus that views were advanced as to their relationship. One was that Hypopus was a ferocious parasite devouring the Tyroglyphus from within; another, that Ilypopus was the male of Tyroglyphus, and a third, that Hypopus was the real adult of certain species of Tyroglyphus. The "Hypopus question" disturbed acarologists for a long time, but through the work of Mégnin and Michael it has been settled. In some species of Glyciphagus the Hypopus is not fully developed and does not escape from the nymphal skin.

Most of the Tyroglyphidx differ but little in general appearance, and the characters that separate species are often few and minute. The family is usually considered to have affinity to the Sarcoptidæand Analgesidx, but there is more resemblance to the nymphs of the Oribatidæ; in fact, Oribatid nymphs have been described as Tyroglyphidæe, and vice versa.

The Tyroglyphidæ feed mostly on vegetable matter; a few live on animal food. They are partial to stored foods, and so are often of much economic interest. A long list of articles attacked by them could be

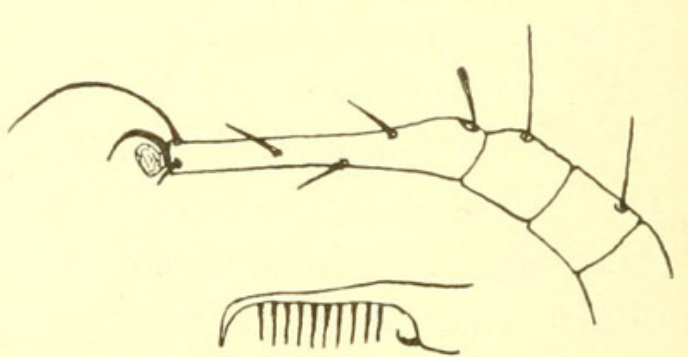

Fig, 157.-LEG I, AND TIP OF MANDIBLE OF HISTIOSTOMA AMERICANA. compiled. It would include cheese, flour, hams, dried meats, hair in furniture, cereals, many drugs, dried fruits, seeds of all kinds, bulbs, feathers, hay, and entomological specimens. Their ravages are due to the enormous number of individuals developed from a few in a short time. Materials attacked by them are often in a fewdays swarming with millions of the tiny creatures. 'How to get rid of them is often a difficult problem. Since they have no tracheæ, they are not very susceptible to fumigation, although some of them will succumb to such treatment. Flowers of sulphur and carbolic acid are, at times, of much use. But in many cases destruction of the material 
attacked is the only remedy. Since many are carried in the hypopial stage on flies, it is advisable to have the windows screened in all factories where cereals, drugs, dried meats, and fruits are prepared. When very abundant the Tyroglyphids are attacked by various predaceous mites, chiefly Cheyletus and Gamasus, which greatly reduce their numbers, and in some cases entirely destroy them.

Various species have at different times been recorded as temporarily parasitic on man, causing itching and soreness of skin. Persons handling infested products are apt to become attacked.

The genera known to occur in the fauna of the United States may be distinguished as follows:

1. Dorsal tegument more or less granulate; claws very weak, almost invisible; some hairs of body are plainly feathered; ventral apertures large....... Glyciphagus

Dorsal tegument not granulate; claws distinct; no prominent feathered hairs; ventral apertures smaller . . . . . . . . . . . . . . . . . . . . . . . . . 2

2. Mandibles not chelate, elongate, and toothed below; body without long hairs; palpi enlarged at tip, and provided with two divergent bristles; body often

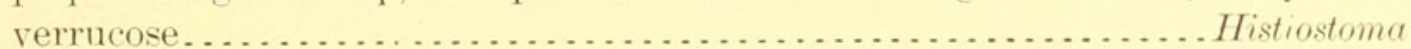

Mandibles chelate, not elongate; body usually with some long hairs; palpi not very distinct, not enlarged at tip, nor with the two bristles . . . . . . . . . . 3

3. No suture between the cephalothorax and abdomen; male lacking sucking disks near anal aperture; claws arising from a membraneous plate, or else associated

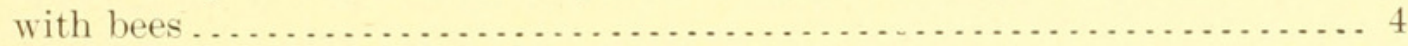

A suture present; male with paranal sucking disks.................. 5

4. Body short; no clavate hair on base of tarsi I and II, a coriaceous piece on anterior margin of cephalothorax, or with a dorsal shield; living on bees, or in their nests; epimera of legs I and II not connected ............ Trichotarsus

Body not short; with clavate hair on tarsi I and II; no coriaceous shields or pieces; epimera of legs I and II are connected; claws arising from tip of a membraneous extension of the tarsus; living on dried fruit...... Carpoglyphus

5. Body elongate; hind pairs of legs arising much behind the anterior pairs; the

Hypopus with eye-like spots.......................... Histiogaster

Body not elongate; hind pairs of legs much nearer to anterior pairs......... 6

6. No sucker at tips of tarsi; leg I never thickened; in some males leg III is thickened; tarsi with stout spines ......................... Rhizoglyphus

A sucker at tips of tarsi, although sometimes weak; leg III never thickened; no spines (only bristles) on tarsi . . . . . . . . . . . . . . . . . . . . . 7

7. Leg I of male thickened; palpi quite distinct and separate ............ Aleurobius

Leg I of male not thickened; palpi less distinct and more appressed to rostrum.

Tyroglyphus

The Hypopi of the various genera, as far as known, can be separated by the following table:

1. A pair of clasping organs on venter near tip of body, margins not sharp-edged. Labidophorus

No clasping organs, but an area of suckers

2. Anterior legs end in very large claws; margins of body not sharp-edged. Trichotarsus Claws small or of normal size.................................. 3

3. An eye-like spot each side on anterior part of body . . . . . . . . . . . . Histiogaster

No such eye-like spots . . . . . . . . . . . . . . . . . . . . . . . . . . . . 4

Proc. N. M. vol. xxviii- $-04-6$ 
4. Venter behind with a submarginal crescentic plate; tarsi rather long...... Hericic

No such crescentic plate....................................... 5

5. Legs very slender, especially the tarsi; hind legs often bent forward .. Histiostoma Legs much shorter, the tarsi not slender . . . . . . . . . . . . . . . . . . . 6

6. Four pairs of suckers in the plate arranged $2-2-2-2 \ldots \ldots \ldots \ldots . . . . .$. Aleurobius Suckers not in such arrangement............... Rhizoglyphus and Tyroglyphus

Of the genus Mistiostoma we have at least two species. The hypopial stage of one (H. muscarum) is often attached to house flies; the other species, $I$. americamum, was taken under bark, which was also infested with a Rhizoglyphus. This species has a number of humps on the dorsum of the body, and upon the summit of each is a small hair. In Europe one species lives in mushrooms, and spreads a disease that causes the decay of the

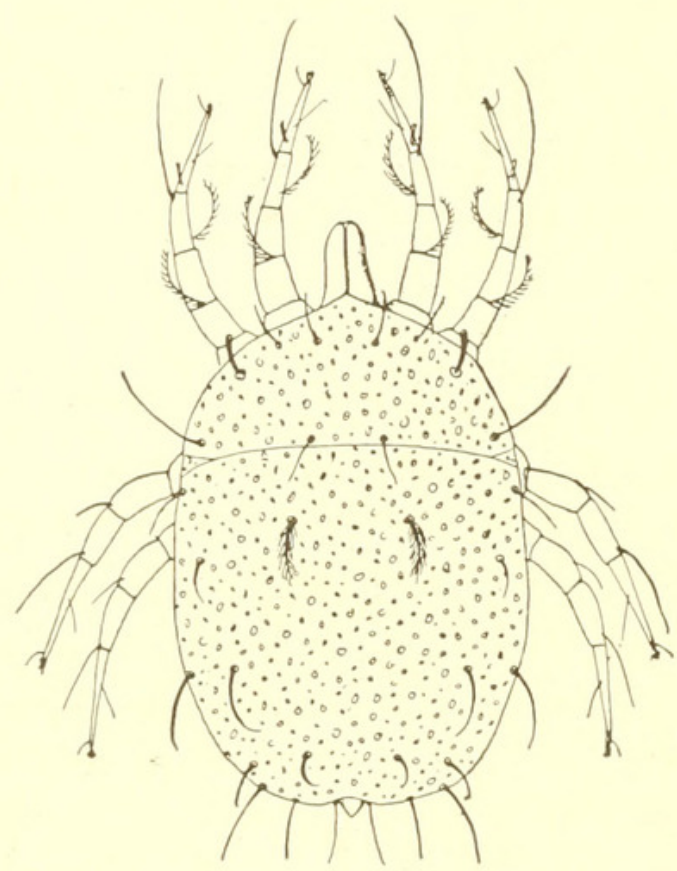

Fig. 15S.-GLYCIPHAGUS OBESUS.

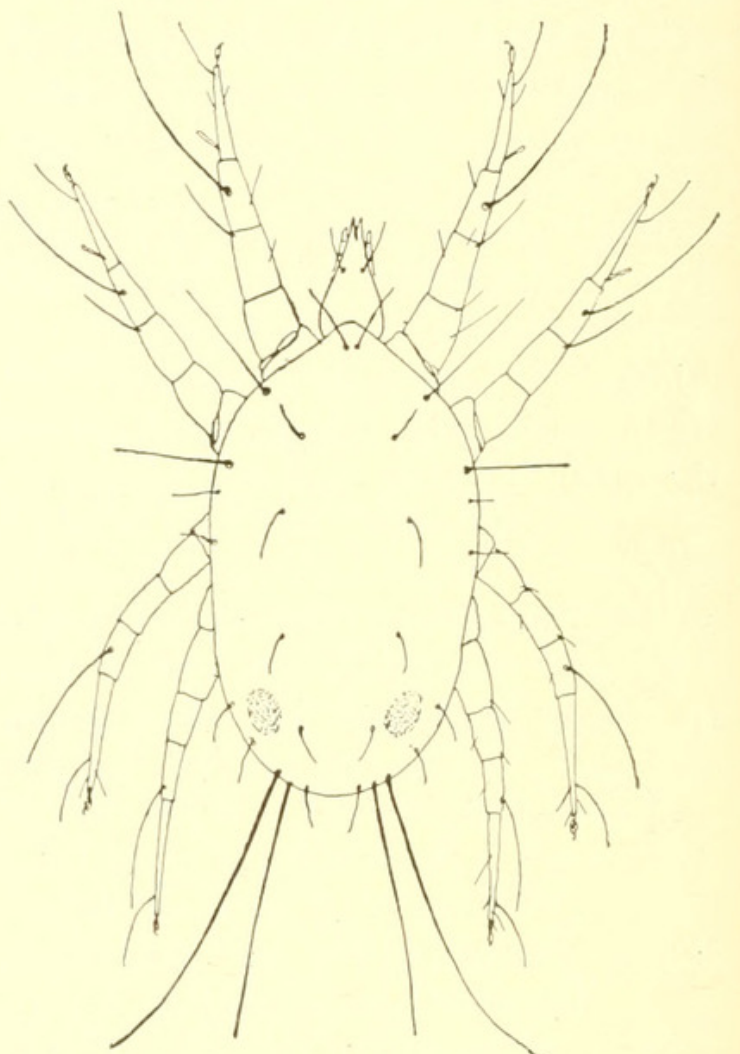

FIG. 159.-CARPOGLYPHUS PASSULARUM, MALE.

pileus. Nearly all the species occur in decaying materials, but Jensen has recorded that one species ( $H$. berghi) lives parasitically in the egg-capsule of a horse-leech in Denmark. The eggs hatch into sixlegged larvæ, which soon molt into the nymph. The latter devours the embryonic leech and then passes into a Hypopus. This escapes from the capsule, attaches itself to an insect, and, on reaching suitable locality, molts into a full-grown nymph. The latter cuts through the capsule, enters, and there transforms to the adult mite. Here reproduction takes place, and the life-cycle begins anew.

The genus Glyciphagus does not appear to be as common in this country as in Europe, possibly owing to their minute size. Two species are known to me, both of rather modest appearance. One has long plumose hairs on the body, and was found in seeds. In Europe several species appear to be common in houses and buildings. some species are provided with many broad scale-like hairs. In all the forms 
the skin is finely granulate, which character serves to distinguish it from all other Tyroglyphids. The original species of the genus (as indicated by the name) and some others have been found in sugar. The mites sometimes spread to the hands of those handling such materials, and produce a skin disease known as "grocers' itch." Michael has described two remarkable forms which he discovered in the nest of the mole. The body is broad, flat, and the margins crenulate and provided with spines. They do not occur in deserted nests, but their relation to the mole is unknown. They may, perhaps, form a distinct genus.

The curious genus Labido-

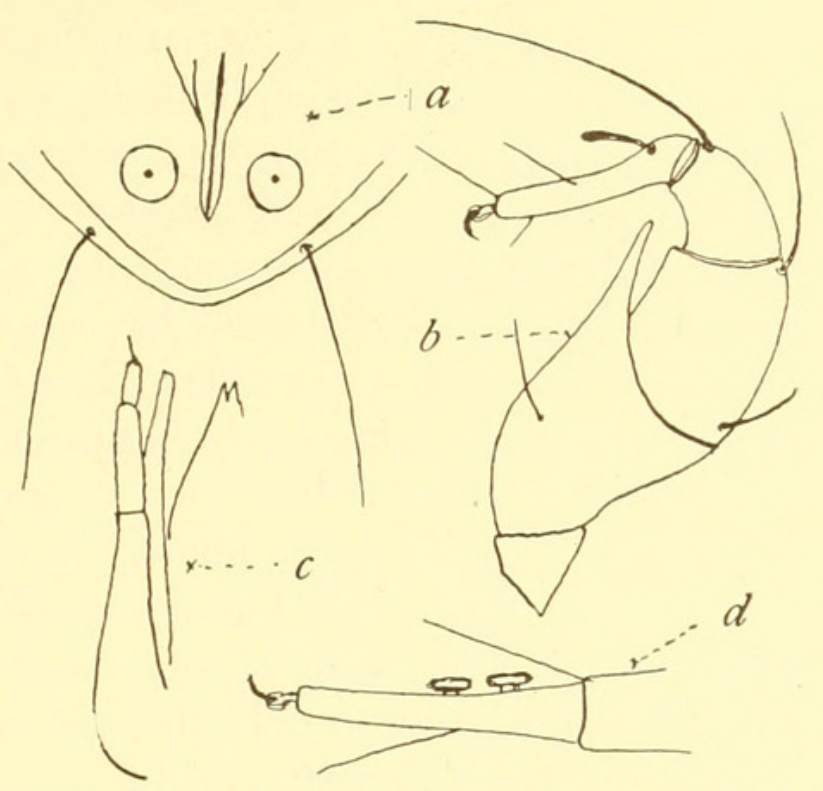

Fig. 160.-Aleurobius Farine; $a$, Venter of MALE; $b$, LEG I OF MALE; $c$, PALPUS; $d$, TARSUS IV OF MALE.

phorus has not been found in this country. The genus was based on a Hypopus that is found attached to moles. Michael has worked out its life history, finding that the adult is much like Glyciphagus. The

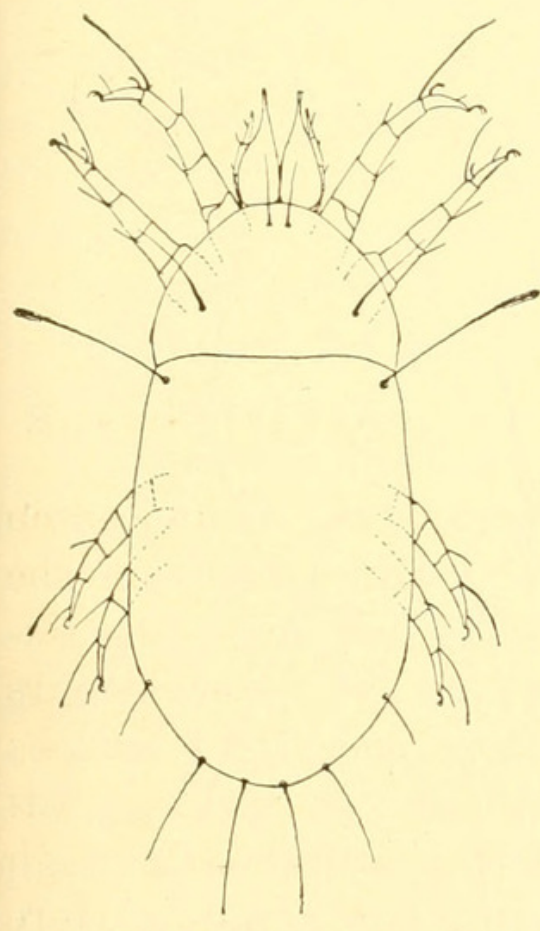

Fig. 161.-Histiogaster yalus, FEMALE. male has several curious comb-like projections from the under side of the first and second pairs of legs, and some plumose bristles on the other legs.

The genus Aleurobius contains one species, A. farinæ, which appears to be wellnigh cosmopolitan. It is the species most commonly found in flour, grain, and stored foods. The greatly enlarged anterior legs of the male are a unique character in the family. The body has a few rather short hairs. Cleanliness, window screens, and frequent handling of the grain will be the best preventives for the protection of mills against this pest. Fumigation with hydrocyanic acid gas is the best remedy.

Tyroglyphus, the typical genus, is known in this country by three or four species, two of which are very common. One, a species in grain and stored foods, appears to be the true cheese mite, T. siro Linnæus. Our specimens, however, have rather longer hairs on the body than the European specimens. Our other common species is the mushroom mite, T. lintneri Osborn. It is very close to the European 
T. longior Gervais, but the bristles are smooth. This species at times is very destructive to cultivated mushrooms, and once in a bed it is very difficult to eradicate. Busck ${ }^{a}$ has given an account of experiments against it which serve to show the difficulty of dealing with the pest. Severely infested beds should be destroyed, and perhaps if the earth was steam-heated (as is done for root-

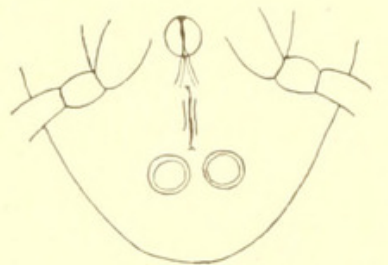

Fig, 162.-H1STIOGASTER MALUS, MANDIBLE AND VENTER. worms), the eggs would be killed. Another species has been taken by Hubbard on oranges in Florida. It is found among the Mytilaspis scales, and is supposed to feed on them. Moniez has described a species, T. wasmanni, as occurring abundantly in nests of certain ants.

The genus Mistiogaster was based on the European $I I$. carpio, and $I$. entomophagus. Our species, M. malus, described by Shimer and Riley, is evidently a different species. It is found on trees infested with scale insects, and particularly in company with the oystershell bark-louse. It feeds on the scale, possibly, however, only after the latter is dead. The body is more elongate than in Tyroglyphus, and the hairs are quite short. In England a species feeds within decaying reeds. The Hypopus of Mistiogaster has a glassy, eye-like spot on each anterior side of the body; it may be an organ of vision, but there is no definite evidence for this view.

To the genus Rhizoglyphus belong a number of species, found on the ground, in decay ing matter, on roots of plants, and in bulbs. The body is slightly more pyriform than in most Tyroglyphids, and the species are of rather large size. We have several species in the United States. One of them is the R. hyacinthi Boisduval ( $R$.

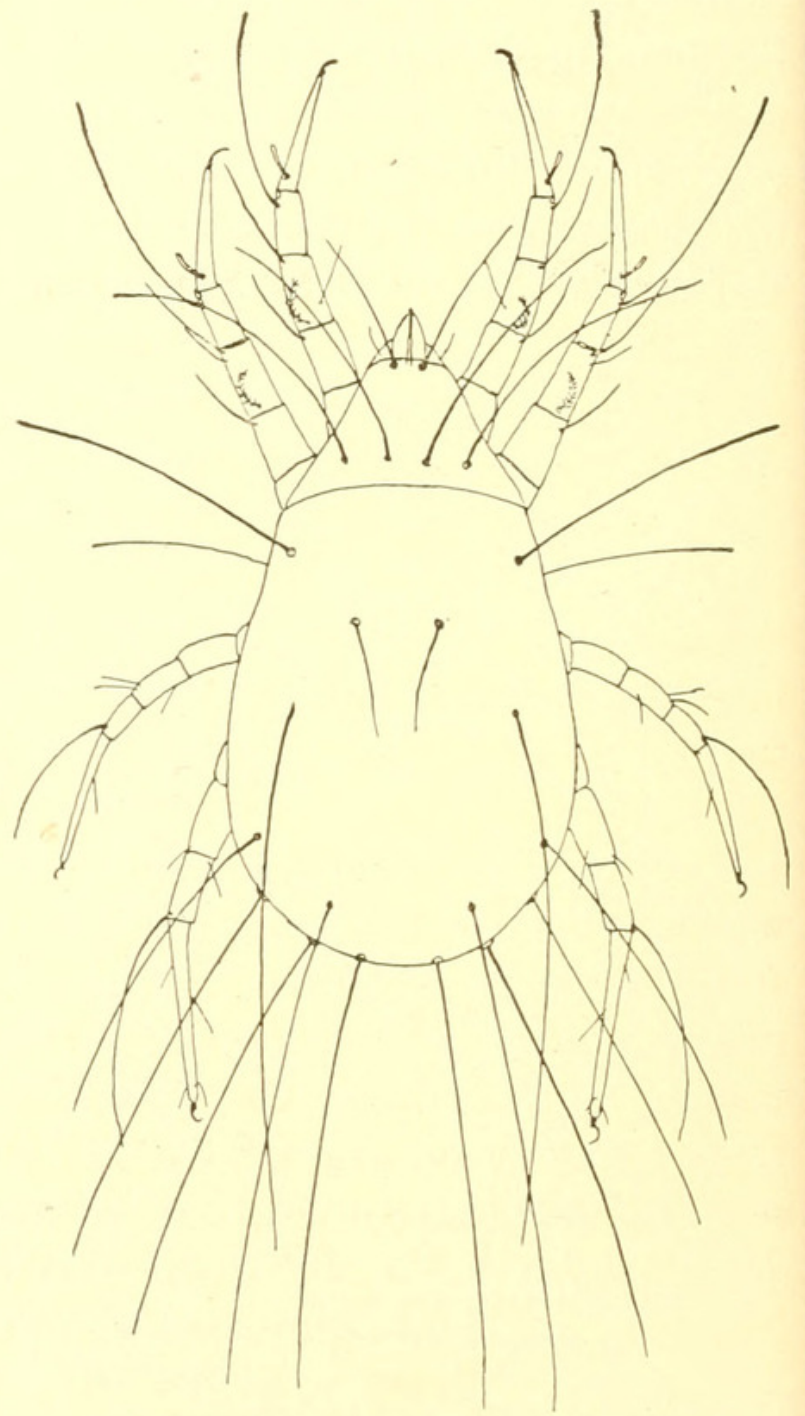

Fig. 163.-TYRoglyPHUS LINTNERI. FEMALE. echinopms Fumouze et Robin). This is the "bulb mite" or "Eucharis 
mite" of the horticulturists, and is responsible for an enormous amount of damage. It burrows into healthy tissue, thereby giving entrance to destructive fungi and bacteria. It is especially common in hothouses, where its ravages on orchids have long been known. No one appears to have found a successful treatment. The best way is to burn the affected bulbs as soon as discovered. Some growers, however, secure good results by the following treatment: The soil of the pots of infested plants is allowed to become dry, then the bulbs taken out and washed in a solution of tobacco water and soft soap, with a small amount of washing soda. Then they are sprinkled with freshly slaked lime and left for two days. Then they are washed with the same solution as before, to which a little petroleum has been added. They are then re-potted and often do well. Mr. Woods has shown that this mite, when infesting Bermuda lilies, can not be destroyed, but much good is accomplished by the use of commercial fertilizers, and rotation of crops.

In Europe it has lately been proved that this, or an allied species, does great damage to the roots of grapevines, and that it may be destroyed by the use of carbon bisnlphide injected into the soil above the infested roots.

Dr. E. P. Felt has described a species, $R$. heteromorphus, which caused injuries to the stems of carnations grown in

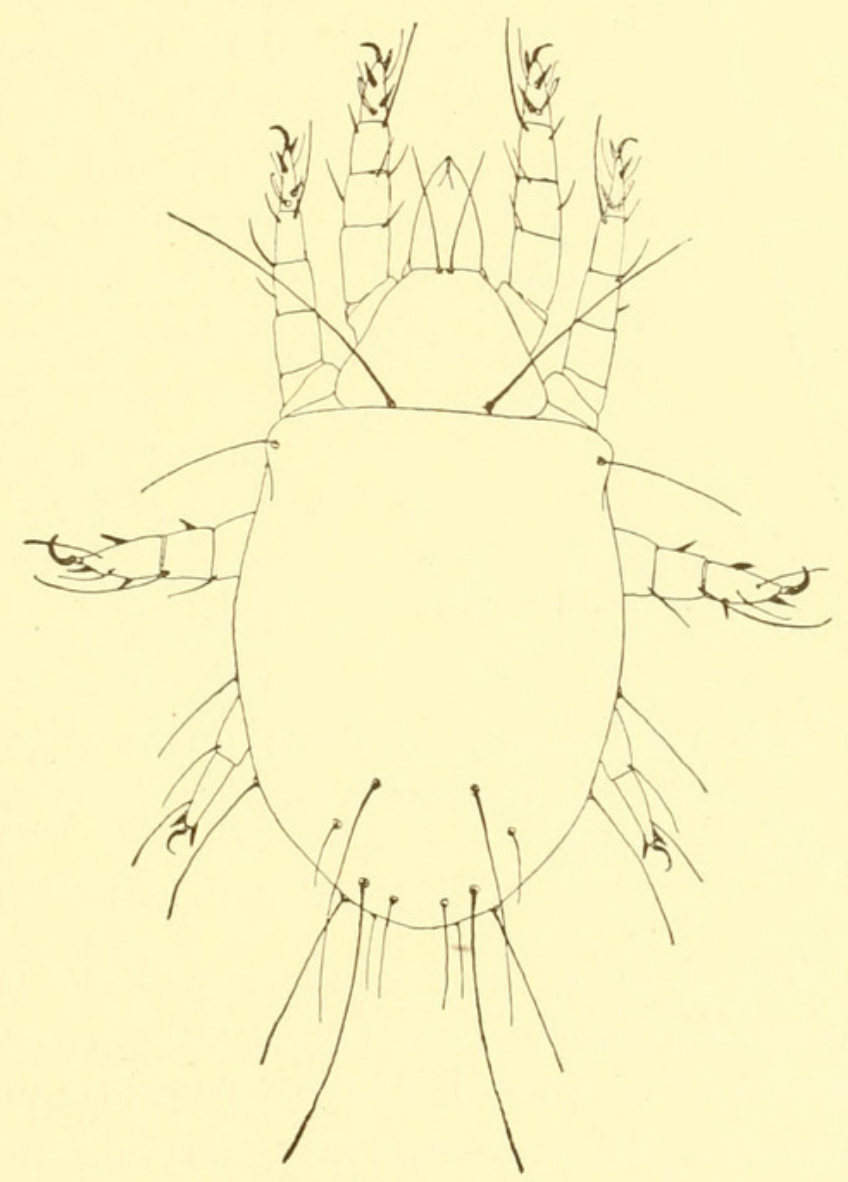

Fig. 164.-RHIZOGLYPHUS RHIZOPHAGUS.

greenhouses. We have seen the same, or closely allied species, on the roots of asparagus. Another species has been found to eat through the grafting wax on budded plants, bore beneath the bark, and so prevent the union of graft and stock. A species described by Riley, R. phylloxerx, was supposed to feed on the Phylloxera, but it doubtless fed on the grape roots.

The typical species of Carpoglyphus, C. passularum, has been found on dried figs in California. It infests dried fruit in Europe. In this genus there is no furrow separating the cephalothorax and abdomen. The position of the long hair on the tibia of legs I and II is different from that of any other Tyroglyphid. This hair is normally near the 
tip of the tibia, but in this genus it arises near the middle of the joint. There are only short hairs on the dorsum of body, but at the tip are two long hairs each side. The Hypopus of this

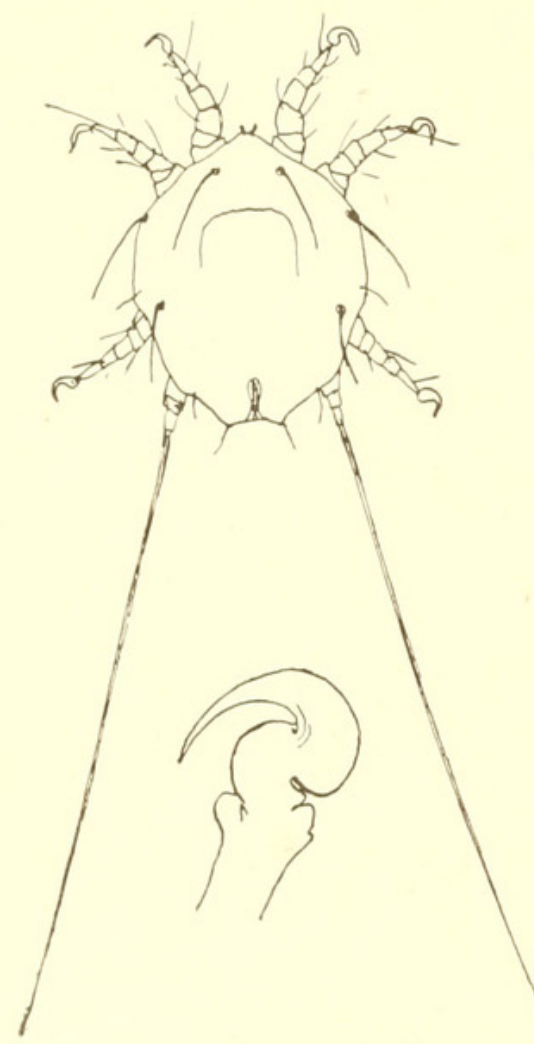

Fig. 165.-TRICHOTARSUS XYLOCOPE; NYMPH, AND CLAW ENLARGED. genus is unknown. It is claimed that the female is ovoviviparous. The species of the genus Trichotarsus (formerly Trichodactylus) are peculiar in that they occur in hypopial form on bees. They have a broad body, without division into cephalothorax and abdomen, and provided with a few short hairs. Two species, T. xylocopx and $T$. osmix, are common in Europe, and both have been recorded from this country. The adult of one species was found in the bee's nest, and has much the appearance of the ordinary Tyroglyphes.

The European genus Hericia is allied to Trichotarsus, and is found in the sap flowing from wounds on trees. Two other European genera, Chortoglyphus and Fusacams, have coriaceous bodies, and the mouth-parts are not visible from above. The former has been taken in old hay and similar substances, and the latter from moles' nests. The genus Lentungula, found on marine algæ in England and Heligoland, is peculiar in having a slender hook-tipped process near the tips of tarsi I and II.

\section{Family CANESTRINIIDA.}

This family, named in honor of the famous Italian acarologist, Giovanni Canestrini, comprises only a few forms of very small size and parasitic on insects. They are related to the Sarcoptidæ, and also apparently to the Tyroglyphidæ. The body is entire, although there is usually an indication of the transverse furrow on the dorsum. The legs are rather short, with few hairs, and terminate in a sucker like that of the Listrophoridx. The mouth-parts are small and concealed in the rostrum; the mandibles generally chelate. The palpi are simple and filiform. There are sometimes two suckers on the hind part of the venter for copulatory purposes. The dorsum bears

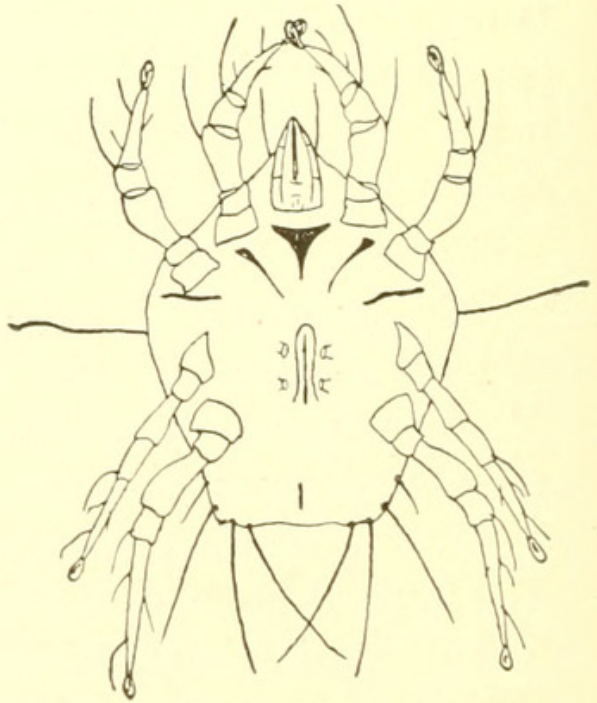

Fig. 166.-Canestrinia sp., female, FROM BELOW.

a few hairs or bristles and some longer ones at tip. Their life history has not been investigated. Most of the species occur on beetles, some under 
the elytra. One species that has been recorded from this country, Hemisarcoptes coccisugus Lignières, is said to live among the egg's of Mytilaspis pomorum. The principal genus is Canestrinia, represented by five or six species.

\section{Family ANALGESID E.}

The bird-mites (Sarcoptides plumicoles of Mégnin) form one of the largest and best-known groups of the Acarina. Since the specimens can be found on the skins of birds, collections have been made in various museums, so that many species occurring in tropical countries are described - a condition not existing in other groups of mites, except the Ixodidæ. The species in the United States, however, have been but little studied. The body of an Analgesid is more or less elongate; the skin is soft and transversely wrinkled; in many forms there are finely granulate dorsal shields, one anterior, and a longer posterior one; there are neither eyes nor stigmata; there is usually a distinction between cephalothorax and abdomen. In front there is a conical projection, the rostrum; the upper part of this is known as the epistoma, and is continuous with the dorsal surface of the body. Beneath the epistoma is a pair of triangular simple mandibles, which often project beyond it. The mandibles are commonly chelate, and finely toothed at the tip. Below the jaws are a pair of maxillæ, which

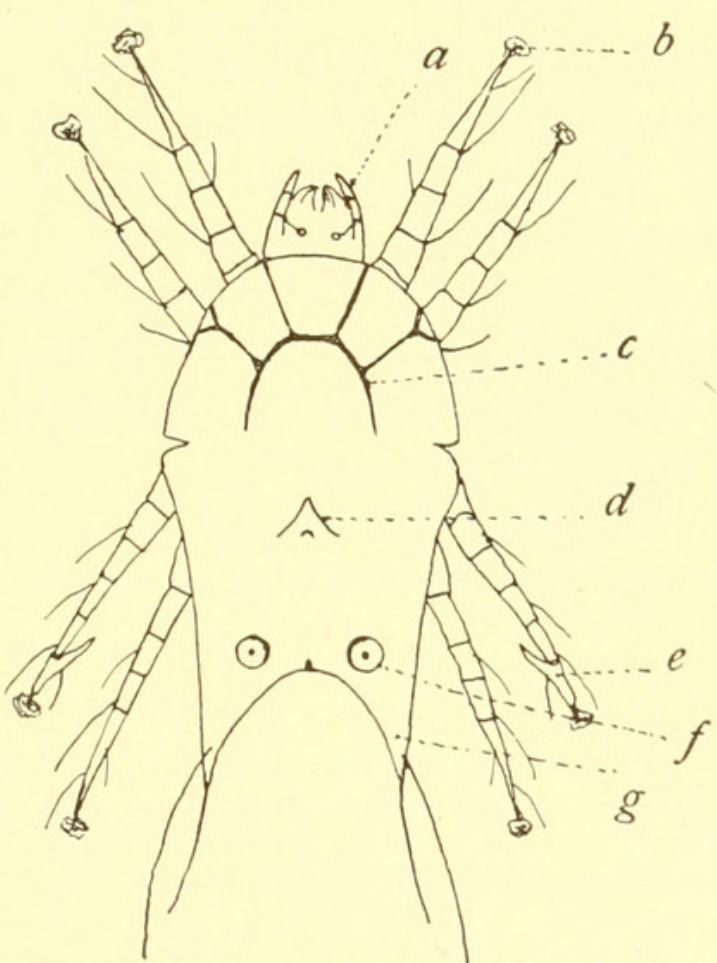

Fig. 167.-ANALgEsid; $a$, PALPUS; $b$, CARONCLE; $c$, EPIMERA; $d$, GENITAL OPENING; $e$, PROCESS; $f$, ANAL SUCKERS; $g$, LOBE. bear on their outer side the simple three-jointed palpi. Below this is the lower lip, and between the two is a ligula or tongue. The legs are commonly short and stout; they are arranged in two groups, the anterior pairs close to the mouth-parts, the posterior pairs toward the end of body. From their insertion on the venter there extend chitinous brown rod-like pieces, the epimera, which form a framework or skeleton for the attachment of muscles and support of the legs. The legs are of five joints, the last ending in a cup or saucer-shaped sucker or ambulacrum. Sometimes there are one or two claws. The legs bear a few hairs or bristles, in a definite arrangement. The two hind pairs of legs often differ in the two sexes, and in the male one is often enlarged or longer than the other, and used as claspers. Sometimes there are projections or apophyses on the legs. In some forms there 
is a backward projection from some of the basal joints of leg I; these are the olecranon processes. On the dorsum are stiff bristles, the

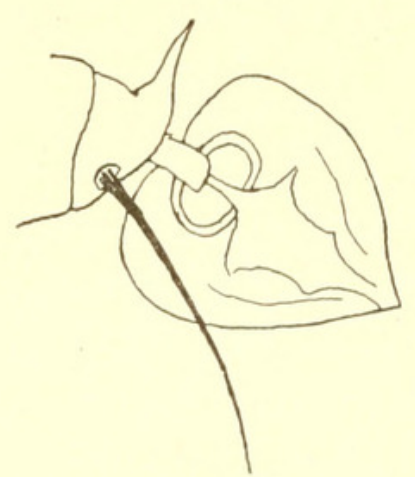

Fig. 168.-CARONCLE OF PTEROLICHUS. size and arrangement of which afford good specific characters. The vulva is situated between the bases of the third and fourth pairs of coxæ; it is usually marked by a curved line, which is termed the lyra. In the male there is a smaller $\mathrm{U}$-shaped mark. The copulatory opening of the female is, however, a small aperture behind the anus. The anal aperture is a simple slit at the tip of the body. Each side of it in the male there is a circular mark or sucking disk; these are the mating or copulatory suckers. The tip of the abdomen is frequently of a different shape in the two sexes. In many genera the male abdomen is deeply bifid or bilobed at tip, while the female has the tip entire. In some forms it is more bifid in the female. In some cases the tip is provided with foliaceous plates or lamellæ. In a few genera there are two forms of the male; in one the mandibles and anterior legs are enlarged.

The development and life history of the bird-

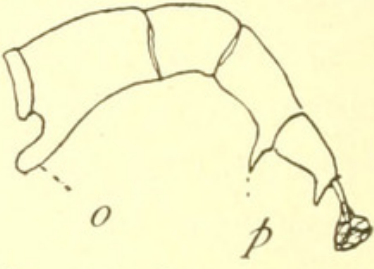

FIG. 169.-LEG OF ANAIGES; $O$, OLECRANON PROCESS; $p$, TARSAL PROCESS. mites are replete with remarkable facts-facts which have puzzled

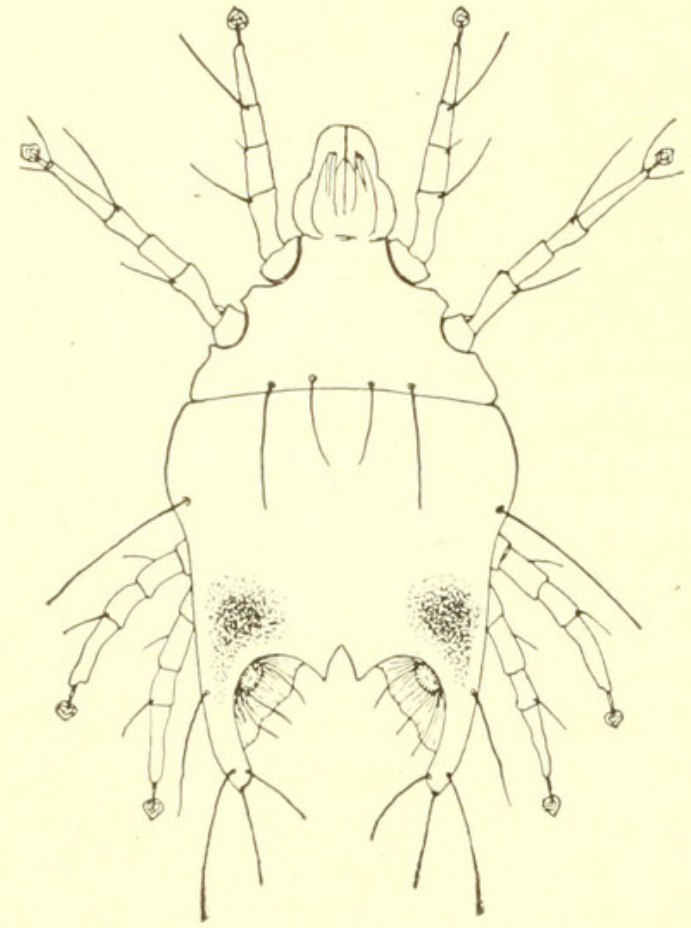

Fig. 170.-PTERolichus SP. (NEAR DELIBATUS), ON CONDOR. investigators for years, and even now not thoroughly understood. The egg is comparatively large, elongate, and slightly curved. The newlyhatched larve have six legs, but in some forms apparently but four. It has been claimed that it is the third pair of legs that is added when the larva transforms to the nymph. The nymph has the general form of the adult, but lacks the genital organs. In certain species there is a hypopial stage developed from the nymph. It is distinguished from the nymph by the absence of mouth-parts, and by having long hairs, instead of a claw, at the tip of leg IV. This stage has on the venter an area of sucking disks similar to that of the Нypopus of the Tyroglyphidx. The adult male is developed from the nymph. But in the case of the female there is a passage form between the nymph and the true adult female. It has 
been called the nymphal or copulating female (femmina accoppiata), for it is in this stage that pairing occurs. 'The male mates with the nymphal female, but pairing is prolonged for several days or until the true adult female is fully developed within this nymphal female. Pairing is performed through a small aperture behind the anus, and not by the vulva, which latter is not developed in the nymphal female and only appears in the adult. The oviduct opens by the vulva. When the true female escapes from the nymphal female, an ego, already of considerable size, is seen within her body.

The Analgeside live upon birds, feeding on the feathers, epidermal scales, etc. They rarely do any damage to the birds, but are usually of service in keeping the skin and feathers clean. They remain on the host after death, often leaving the feathers and congregating on the skin. Although many of the species are now known from but one host, there are some common forms that occur on a considerable number of birds, frequently of different genera. Likewise several species of mites sometimes occur on the same bird.

These mites were for a long time kept in the genus Dermaleichus Koch, but this has been shown to be a synonym of Analges Nitzsch, 1818. Many other genera have been formed in recent years, and a revision of the family by Canestrini, in "Das Tierreich," in 1899, includes 31 genera

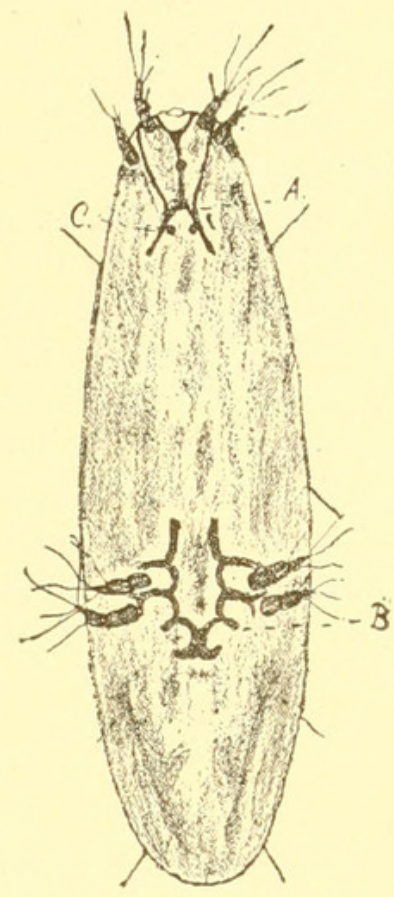

FIG. 171.-HYPODERAS COLUMBA, A STAGE OF FALCULIFER; $a, b, c$, EPIMERA (KELLICOTT). and 7 subgenera. Several, however, are based on very slight characters, and do not appear advisable.

But few species have been recorded from this country. Mr. Tyrrell and Professor Haller described several from Canada, and Doctor Trouessart has taken some from American birds in the Paris museums.

In the following table I have included all known from the United States and Canada, and most of the larger genera that are apt to be found here.

1. Hind legs of the male not lengthened nor enlarged $\ldots \ldots \ldots \ldots \ldots \ldots \ldots \ldots \ldots \ldots$ Some of the hind legs larger or longer than the anterior legs............ 8

2. Hind legs situate more under the body, very short; the fore legs of male with processes on some of the joints, body usually quite broad ........... Freyana Hind legs more lateral; legs I and II without projections in male.......... 3

3. Tip of the male with foliaceous appendages; that of the female bifid, and with stout bristles

Proctophyllodes

Male without such appendages. . . . . . . . . . . . . . . . . . . . . . . . 4

4. Female with tip of abdomen bifid, and provided with stout bristles... Pterodectes Female with tip of abdomen entire ............................. 5

5. Body broad, legs very short; in male two hook-like projections from each side

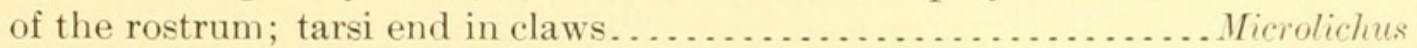

No such projections on rostrum; tarsi rarely end in claws .............. 6 
6. Legs I and II of male longer than the others, and end in claws; two forms of

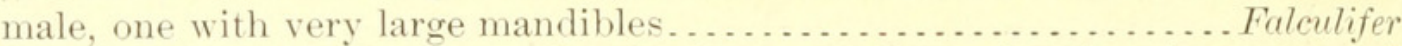

Legs I and II not longer, not ending in claws; one form of male only ....... 7

7. Body soft, weakly chitinized, pale color ...................... Rivoltasia

Body harder, more strongly chitinized; more or less brown in color. . Pterolichus

8. Legs I and II of male with distinct spine-like processes $\ldots \ldots \ldots \ldots \ldots \ldots . . .69$

Legs I and II without such processes . . . . . . . . . . . . . . . . . . . 12

9. Leg III without a sucker, ending in a stout claw; rarely spines on tarsus. Analges

Leg III with a sucker at tip . . . . . . . . . . . . . . . . . . . . . . . . 10

10. Leg III larger than IV, with spines on tarsus . . . . . . . . . . . . Megninia

Leg III scarcely as thick as IV . . . . . . . . . . . . . . . . . . . . . 11

11. Leg III plainly longer than IV . . . . . . . . . . . . . . . . . . . Protalges

Leg III plainly shorter than IV . . . . . . . . . . . . . . . . . . . Pteralloptes

12. Leg IV larger than III . . . . . . . . . . . . . . . . . . . . . . . . . . 13

Leg IV smaller than III ....................................... 15

13. Tip of abdomen of female entire, and usually of male; leg IV very short..... 14

Abdomen of female and usually of male bifid at tip, often deeply so; body slen-

der; leg IV rather slender . . . . . . . . . . . . . . . . . . . . . . . . Alloptes

14. Suckers of tarsi small ...................................... . . . . . . . . . . . . . .

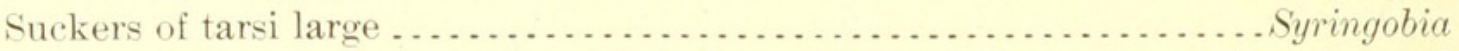

15. Abdomen of male more or less bilobed at tip; leg III usually reaches beyond

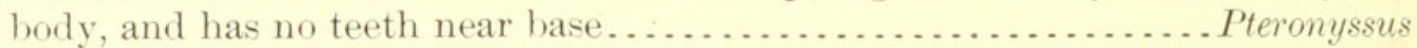
Abdomen of male entire; leg III usually does not reach the tip of body, and has one or two teeth near base on inner side............... Dermoglyphus

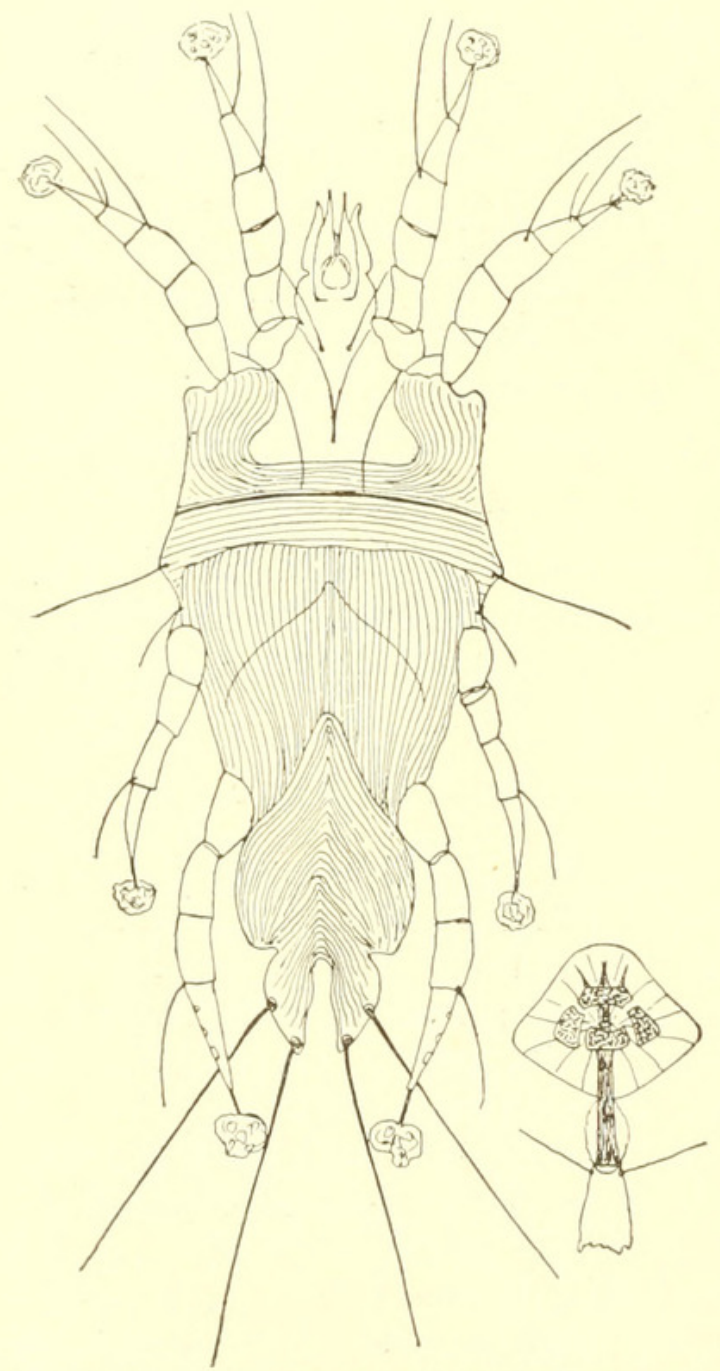

Fig. 172.-ALLOPTES MICROPHETHON, AND CARONCLE.

In Freyana some males have one of the anterior legs, sometimes the left, sometimes the right, greatly enlarged to aid in holding the female. The hind legs arise nearer the middle of the venter than in other genera, and are very short. Two species have been recorded from this country, one, $F$. anserina Koch, on the snow goose, and the other, $F$. caputmedusx Trouessart, on the booby. The latter species is sometimes over 1 millimeter long, one of the largest species of the family. In Pterodectes the body is elongate and slender, the legs all of about equal development, and in both sexes the tip of the abdomen is bilobed, in the female with two stout bristles. There are distinct shields upon the dorsum. The genus Allanalges (Pterocolus) is scarcely different. Professor Haller recorded one species, A. gracilepinnatus, from Canada.

In Proctophyllodes the body is also slightly elongate, and the legs of subequal size. The abdomen in the female is bifid at tip and with two 
stout bristles; in the male it is scarcely bifid and provided with two prominent foliaceous appendages. $P$. reticulifer comes from California.

In Rivoltasia the species are rather short and broad, all legs of about equal size; the male body is deeply bilobed at tip, each lobe provided with a very long hair. They are very small species, and some occur on domestic fowls.

In Microlichus the species are similar to $R$ ivoltasia, but the legs are shorter, and end in distinct claws, and there are two hook-like projections each side of the rostrum near its tip.

In Pterolichus the legs are all subequal in size. There is much variation in the shape of the body, which in the male is bilobed at tip and in the female more or less entire. It is a very large genus, and three species are known to occur in the United States. $P$. aquitinus Trouessart has been taken on the golden and

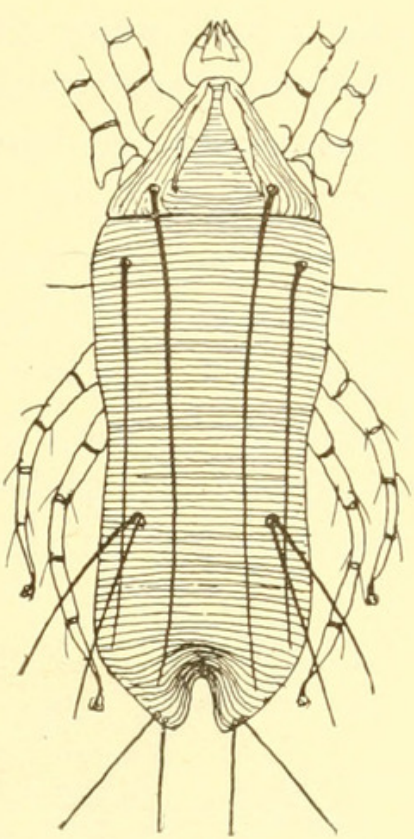

Fig. 173.-ANALGES PASSERINUS, FEMALE.

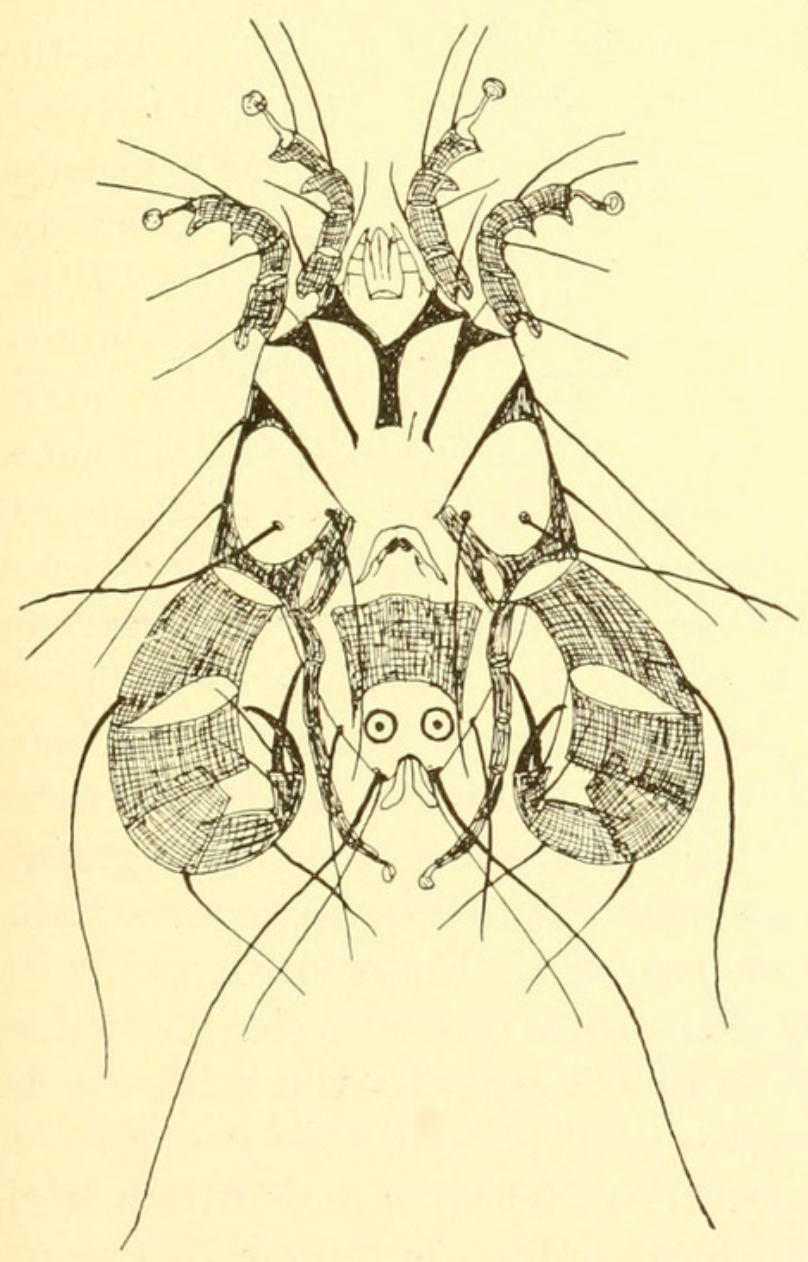

Fig. 174.-ANALGES PASSERINUS, MALE. bald eagles; P. buchholai Canestrini on the godwit and golden

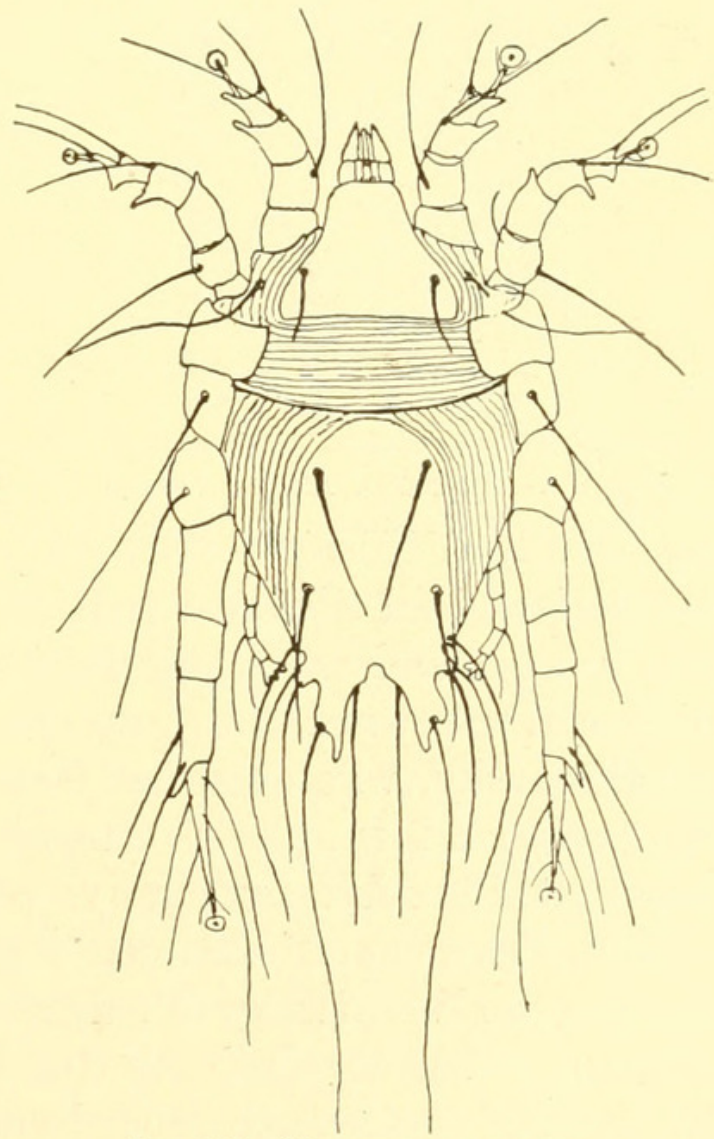

Fig. 175.-MEgNINIA TYRRELLI.

plover; and $P$. longiventer Mégnin and Trouessart on the barred owl. 
The genus Falculifer (formerly Falciger) has but few species, but one of them, $F$. rostratus Buchholz, presents several interesting points. The adult stage differs but little from the normal bird-mite, except that there are two forms of the male - one which has considerable resemblance to the female and the other which has several secondary sexual characters, the anterior pairs of legs being long and heavy and the immovable finger of the mandibles being greatly enlarged and. lengthened. There is, however, an hypopial stage in the life of this mite which has been the theme of much discussion among acarologists for many years. This hypopial form was described in 1861 by Filippi as Irypodectes and by Nitzsch as Hypoderas. Hypodectes is found in various parts of the internal anatomy of birds, generally in the areolar

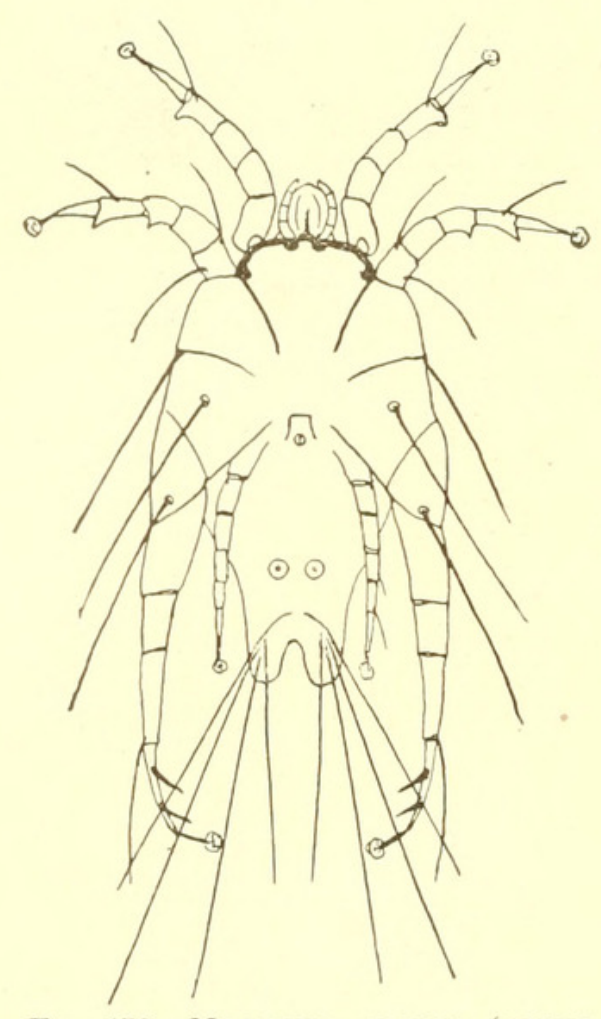

Fig. 176.-MEgNiNiA ALBIDA (AFTER TYRRELL).

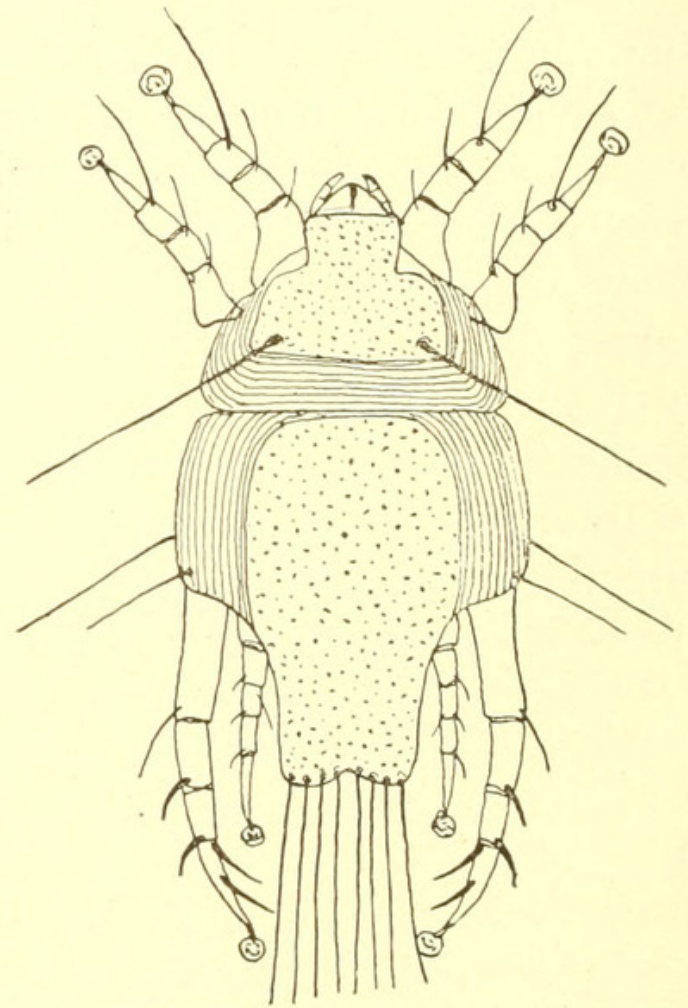

Fig. 177.-PTERonyssus tyrRelli (AFTER HALLER).

and peritracheal tissues. It is of an elongate form, rounded in front and behind, and with eight short legs, two pairs in front and two other pairs toward the posterior end. There are no mouth-organs, and Slosarsky, who examined the anatomy, found no internal structures save a few muscles attached to the legs. From this it was evident that Hypodectes was a nymph in the state of histolysis. Mégnin soon made a more extended study, and found that the mite was a stage in the life-history of a Pterolichus (now placed in the genus Falculifer). Mégnin considers that when the Faculifer finds it is being deprived of shelter and food, by the birds pulling out their feathers, certain normal nymphs transform into the hypopial Hypodectes. This then crawls into the respiratory organs, or into the hair-follicles, burrows some distance, and there remains until normal conditions are 
reestablished when it reappears on the outside. However, it is probable that more is to be learned regarding these subcutaneous forms. In this country Hypodectes has been taken from the pigeon and blue heron, while $\mathrm{Mr}$. Beebe has recorded a similar form from various birds in the New York Zoological Park. This latter form is supposed to have caused the death of a number of birds.

In Pteralloptes the males have the third legs but little larger than front legs, and end in a sucker. They have usually been taken from tropical birds.

In Pteronyssus the male has the third pair of legs much longer than the fourth, which is very small. The tip of the abdomen is nearly truncate in both sexes, but in the male there is often some indication of two lobes. Three species have been described from Canada: $P_{i}$. simplex, on the red-breasted woodpecker; $P$ t. speciosus, on the sap sucker, and Pt. tyrrelli Canestrini (fuscus Tyrrell), on the whitebreasted swallow. Megninia is similar to Pteronyssus, but there are several spinesnear the tip of the third legs, and the tip of the male abdomen is distinctly bifid. They are usually brown in color, and many species are known. Several are described from our birds, as follows: ${ }^{a} M$. aculeatus, on the blue jay; $M$. tyrrelli, on the cat-bird; M. gladiator, on the wild pigeon; $M$. forcipatus

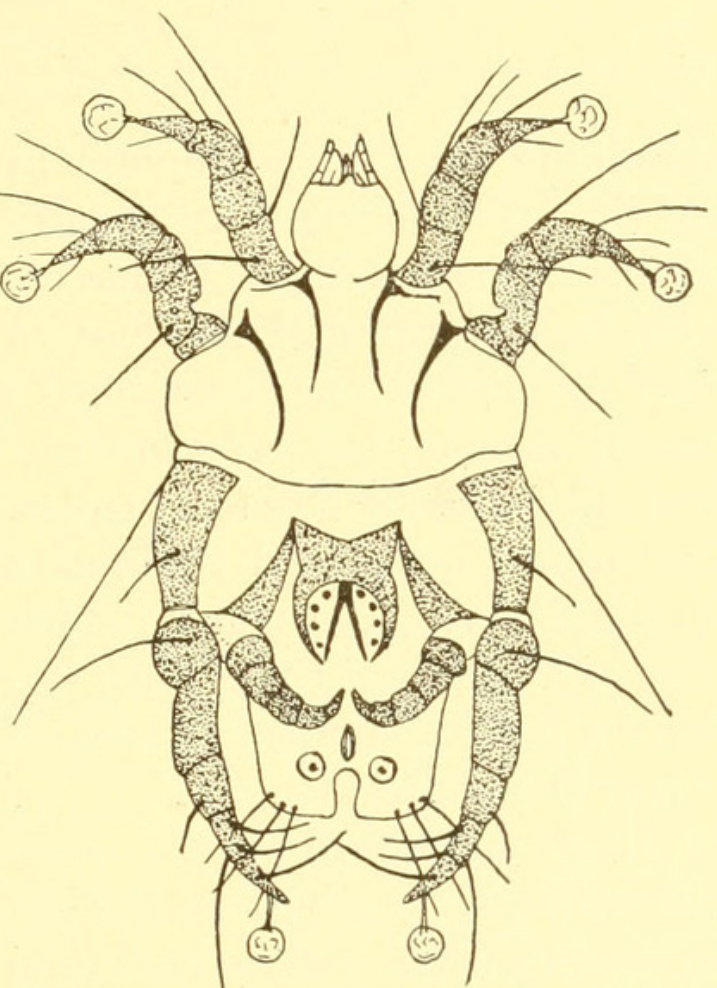

Fig. 178.-Allanalges gracilepinNatus. on sand-pipers; $M$. pici-majoris, on the big sap-sucker, and $M$. albidus on the white-breasted swallow. In Analges the male has the third pair of legs not only longer than the others, but usually very much enlarged in the middle, sometimes enormously so. On legs I and II there are one or two spur-like projections from the tibiæ and tarsi, and on the base of the femur there is a reflexed spur, the olecranon process. The tip of the male abdomen is often pointed, and never deeply bilobed; the female has a rounded tip and elongate body. The tarsal suckers are smaller than in Megninia and Pteromyssus. Five species have been described from American birds: A. tyrami, on the king-bird; A. longispinosus, on the snow-bunting; A. tridentulatus, on the horned lark; A. cremidonotus

a Several of these species, namely, those described by Prof. Haller in the Zeitschr. f. wiss. Zoologie, 1882, are not mentioned in Prof. Canestrini's treatment of the world species in Das Tierreich, Lief. 7, 1899. 
Trouessart from California; A. digitatus Haller, on the Canadian warbler; and the European A. passerimus Linnæus recorded from several small birds.

\section{Family LISTROPHORIDA.}

The members of this family (Sarcoptides gliricoles of Mégnin) are closely related to the bird-mites, but live upon many of the smaller mammals, including bats. They are small, soft-bodied, and with short

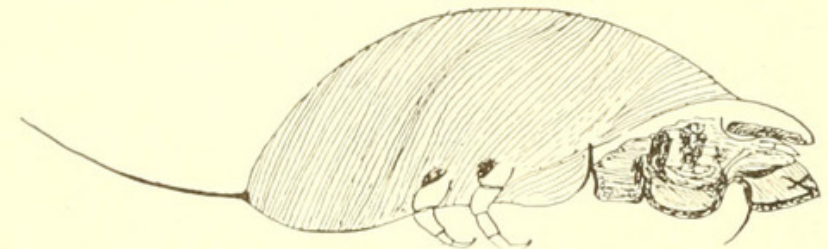

Fig. 179.-SCHIZOCARPUS MNGAUDI, FEMALE, SIDE VIEW. and stout legs, terminating in a sucker and often a slender claw. The body usually tapers a little behind, and the legs are widely separate, one from the other, sometimes each pair is at an equal distance from the adjoining ones. The dorsum has a few short hairs, with longer ones at tip. The surface is usually transversely striate. The rostrum or beak forms a distinct cone on the front of the body; the palpi are simple, filiform, and lie close to the underside of the beak; they are three-jointed. The mandibles are commonly chelate, but very small. The genital apertures are situate between the third and fourth coxie, and the anus at the tip of the body. The males, which are usually of a different shape than the females, have a pair of copulatory suckers near the tip of the venter.

These mites feed on the hairs of small mammals, and each genus has some special apparatus wherewith to hold onto the hair. In Listrophorus the under lip is expanded on each side into a flexible plate which curls around the hair. They occur on rabbits, squirrels, and mice. In Myocoptes the hind pairs of legs are enlarged, the apical joints provided with a few large spurs, and these joints can fold back on the basal joints as a knife-blade. By this arrangement they cling to the hair of

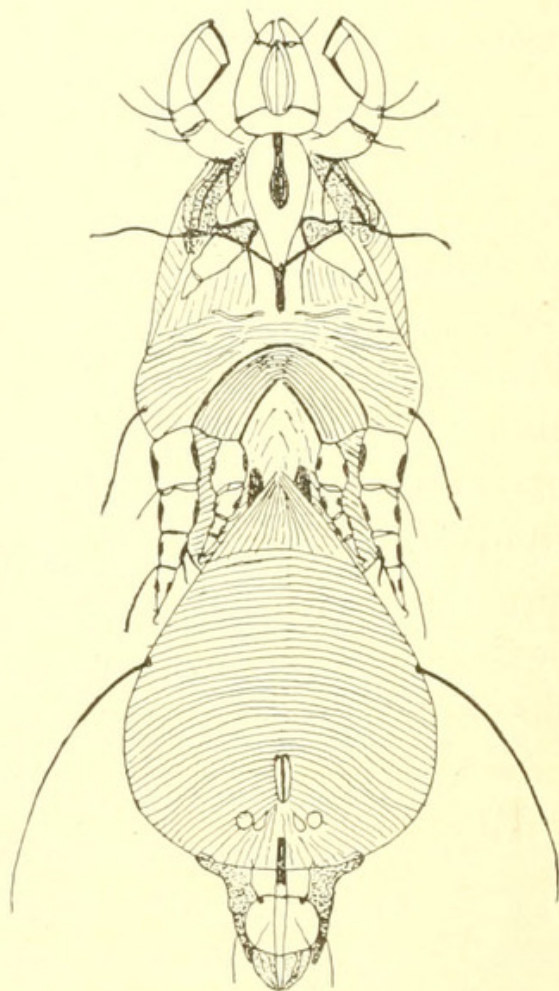

FIG. 180.-SCHIZOCARPUS MNGAUDI, MALE AND FEMAI.E TOGETHER. mice. In Trichacius the hind tarsal joint is flattened, curved, and provided with a spine, which enables the mite to grasp the hair of mice. In Labidocarpus, which occurs on bats, the anterior legs are very short and the last joint enlarged and concave below. By these they clasp hairs. The hind legs are normal. Schizocarpus has a similar arrangement; it occurs on the beaver. In Chirodiscus the anterior legs have the apical joints flattened and curled, but destitute of claws and sucker. 
Little is known regarding their life history. In Labidocarpus the male mates with a nymphal female (as in the Analgesidæ), which moults, and the true female issues only to deposit egg's. Some species of Listrophorus are preyed upon by a species of Cheyletus that uses the rabbit's fur as a hunting forest.

This family is based on the pilicolus habit and the possession of some apparatus to cling to the hair. Since this apparatus is very different in the various genera it has been surmised that the family is not a natural one, but includes forms really belonging to the Analgesidæ, Tyroglyphidæ, and Sarcoptidæ.

The American forms, with the exception of Schizocarpus mingandi on the beaver, have not been investigated. That species is, however, very peculiar in many ways. The male has the third pair of legs large, the fourth very small, and mates with a nymphal female, which possesses but one pair of legs. The adult female is of normal appearance. It has been taken in Texas, California, and Washington, and also occurs in Europe.

Labidocarpus has an elongate, tapering body, annulate with many narrow ridges, and at once reminding one of the Eriophyidæ, to which there is, doubtless, some affinity.

\section{Family SARCOPTIDA.}

The itch mites (Sarcoptides psoriques of Mégnin) have long been familiar through their disgusting parasitism of the human subject. They often burrow within the skin of man and other mammals, and thereby produce intense itching, and a diseased condition known as scabies, mange, or more properly acariasis. The mites are very small, white, and semiglobular in shape. The body is entire, and the surface transversely striated and provided with a few bristles, often short, stout, and sharp-pointed. The legs are short and stout, arranged in two groups. The anterior legs are usually larger than the others. The tarsi commonly terminate in a stout claw. There is generally a long pedicellate sucker, sometimes with a jointed pedicel. The claw or sucker may be absent and in its place a long bristle. The

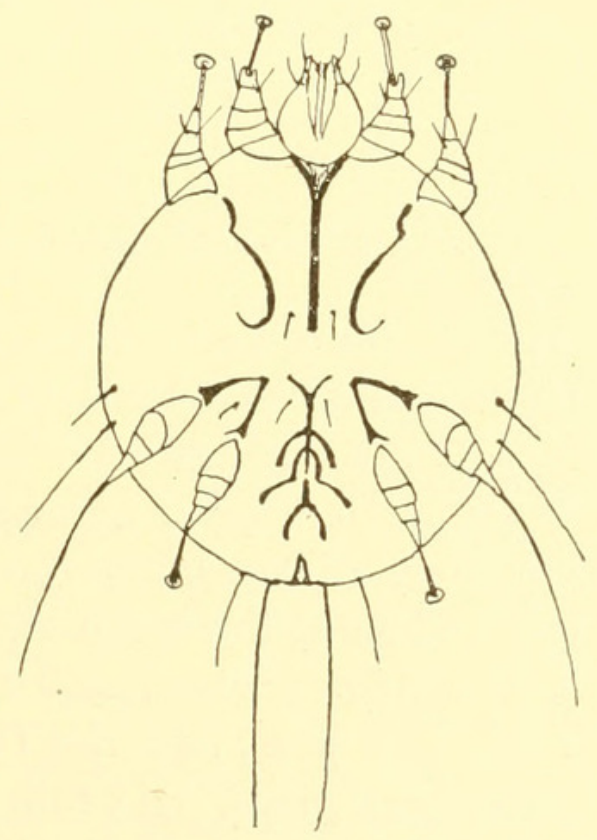

Fig. 181.-SARCOPTES HOMINIS, MAI.E. legs often show a chitinous framework of rings, both transverse and oblique. On the front of the body is a prominent beak. The palpi are small, three-jointed, and appressed to the sides of the beak beneath. 
The mandibles are chelate ${ }^{a}$ and vary in length with the genus. The ventral openings are in the usual position, and in the male there is often a pair of copulatory suckers near the tip. There are frequently sexual differences; some males have the third pair of legs very large and long, while the fourch pair is very small. Sometimes there are plate-like lobes at the tip of male abdomen, and the tarsi may terminate differentiy in the two sexes. The Sarcoptide live in the skin of mammals, including man and a few birds. The female burrows into the skin, depositing eggs on the way. The young, on hatching, start burrows of their own, so that a host is infested in patches. These burrows or cuniculi are close to the surface, and sometimes result in loosening pieces of the epidermis so as to produce a scaly effect or

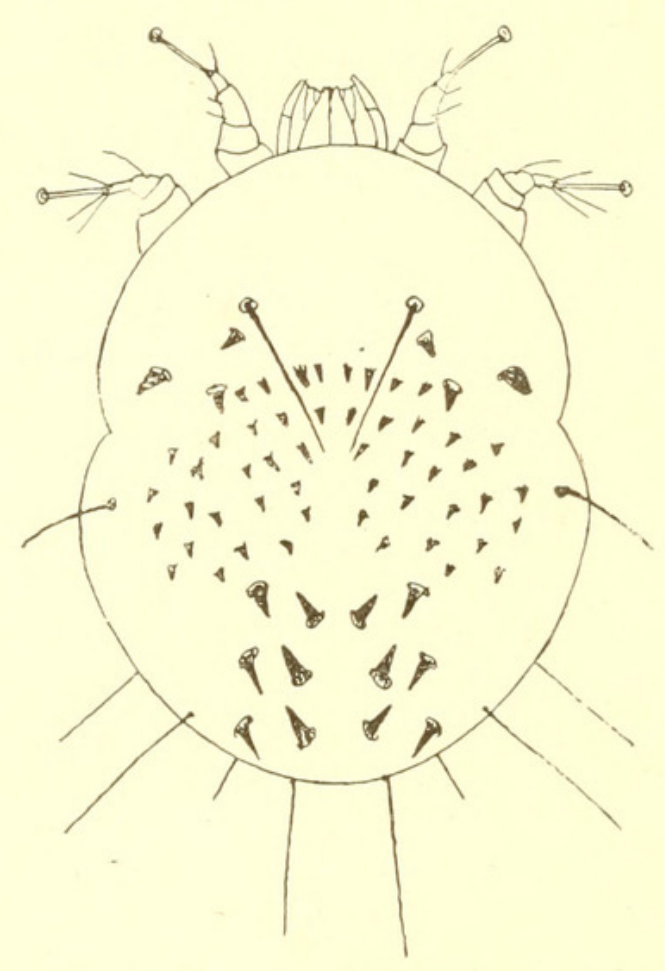

FIG. 182.-SARCOPTES HOMINIS, FEMAJ.E.

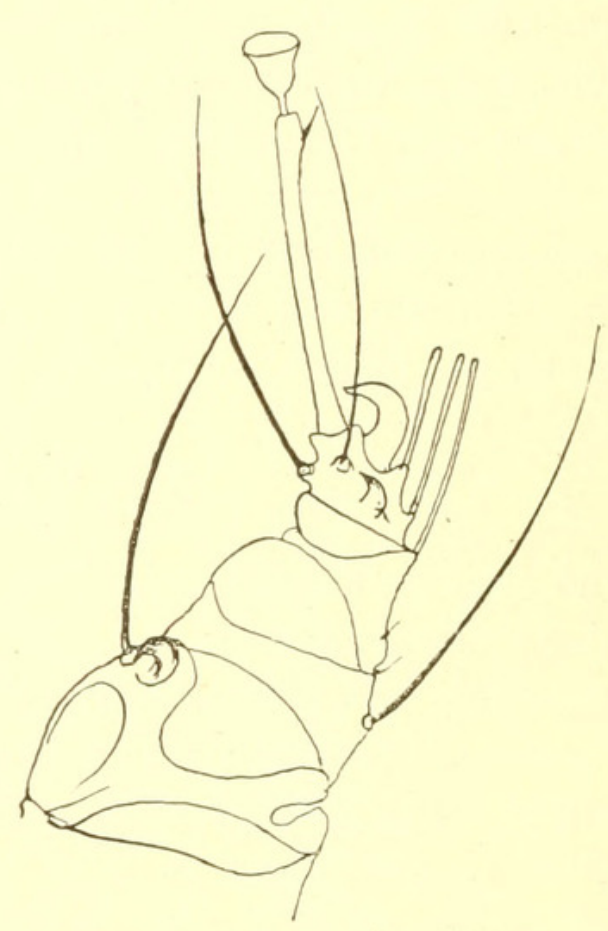

FIG. 183.-LEG OF A SARCOPTES.

crust. Frequently there are vesicles, papules or pustules, which may become ulcerated by scratching. The different species produce different effects, and even the same species when on different animals. When upon a hairy animal, the hair usually falls out in the affected portions. The young Sarcoptes, when newly hatched, has but three pairs of legs; the last ending in a long bristle; and there are no chitinous bands. Some species moult four times before maturity. When adult they pair, and the female wanders a little in search of a good burrowing place. At this time the mites can exist for a long period if removed from their hosts and kept in a moist situation; but if exposed to dryness, they soon die. The burrow is made by eating

a Fürstenberg in his great work, Die Krätzemilben der Menschen, figures two pairs of chelate mandibles; this is a manifest error, and weakens one's faith in his fine figures. 
the tissue, and is of the size of the mite. As the female progresses she leaves behind her a row of from ten to forty large eggs and a considerable amount of "frass." The female, having deposited her complement of eggs, dies at the end of her burrow. As the skin of the host is always wearing off, and constantly being renewed from below, the eggs, when ready to hatch, will be close to the surface, so that the mites may readily escape. Above each burrow there is often a little pimple, containing a watery fluid. There appears to be no

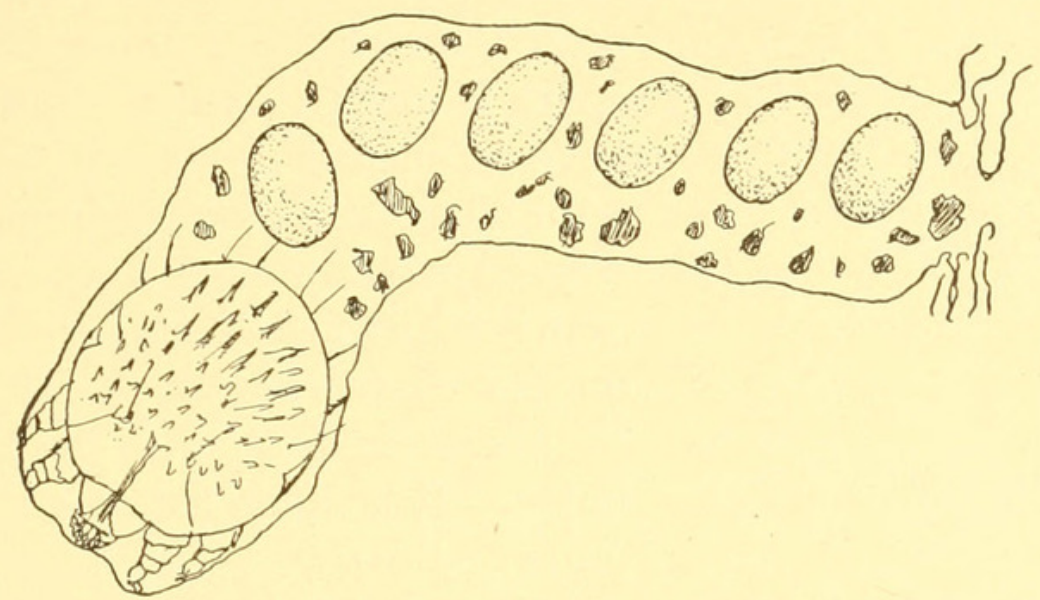

FIG. 184.-SARCOPTES IN HER BURROW, AND EGGS,

means of distribution from individual to individual except by contact. Many of the species that are normally confined to one host can live on other animals and on man. The eggs if kept moist may retain their vitality for a week.

There are but a few genera; the better-known ones may be tabulated as follows:

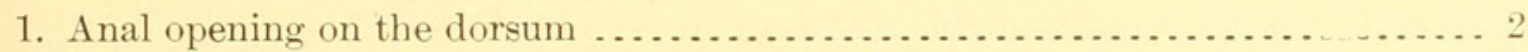

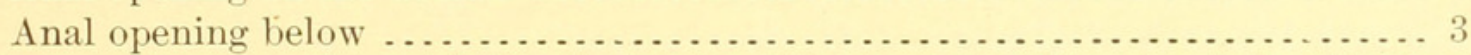

2. On small mammals, not bats; third pair of legs in male without apical suckers.

Notoedres

On bats; third legs in male with suckers .................... Prosopodectes

3. Pedicel of suckers jointed; mandibles styliform and serrate near tip..... Psoroptes

Pedicel not jointed; mandibles chelate . . . . . . . . . . . . . . . . . . . 4

4. No suckers to legs of females; parasitic on birds............... Cnemidocoptes Suckers at least on legs I and II; parasitic on mammals . . . . . . . . . . . 5

5. Legs very short; in male the hind pairs equal in size; body usually short.Sarcoptes Legs more slender; in male the third pair is much larger than the fourth; body

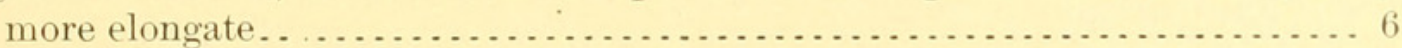

6. Female with suckers to fourth pair of legs . . . . . . . . . . . . . Chorioptes

Female without suckers to fourth legs. . . . . . . . . . . . . . . . . 7

7. Hind part of male abdomen with two lobes. . . . . . . . . . . . . . Caparinia Hind part of male abdomen without lobes.......................... Otodectes

Sarcoptes includes the species parasitic on man, although some others may also occur. The human species is S. scabei. This pest was formerly more common than now, particularly in armies. The intolerable itching caused by the presence of these mites leads to wild and

Proc. N. M. vol. xxviii-04-7 
incessant scratching, which only serves to spread the infection and increase the inflammation.

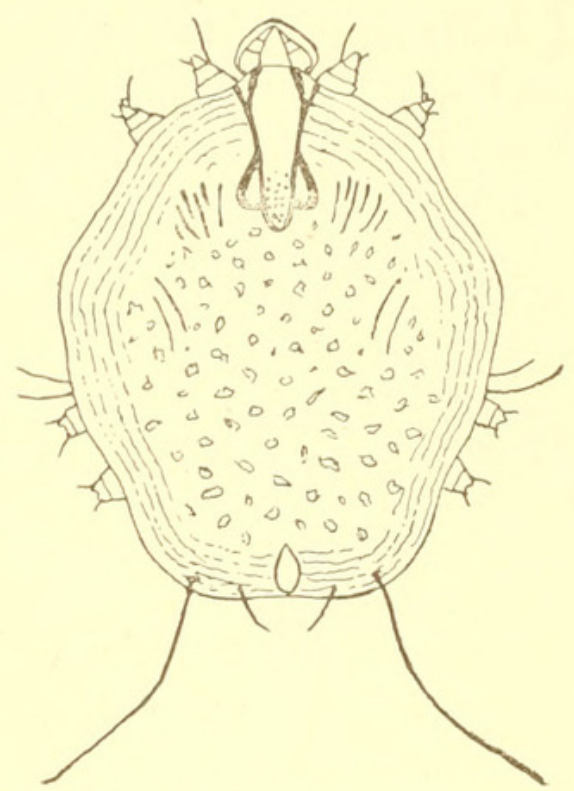

Fig 185.-CNEMIDOCOPTES MUTANS, FEMALE.
Cleanliness is the best preventive. The best remedy is the use of an ointment containing sulphur. If the affected parts are freely bathed in hot water and soapsuds the scaly portions of the skin will be removed, and then the ointment can be applied with a certainty of reaching the mites. The application should be repeated two or three times, each a few days apart, in order to kill any mites that may have hatched since the first application. All underclothes and bedding should be washed in boiling-hot water. The Norwegian itch mite is $S$. scabei-crustosz; it produces a coarse leprous crust infested on the inner surface with myriads of the mites. It is much less common than the other species.

Nearly all of the domestic animals may harbor a species of Sarcoptes peculiar to them. The more common are those of the hog, horse, and sheep. They work like the human species, and are amenable to the same treatment, or that used for sheep-scab.

The species of the genus Psoropteshave piercing mandibles, and do not burrow. One species, $P$. communis var. ovis, is the cause of sheep-scab, a serious disease of this animal throughout the world. The fleece of scabby sheep presents a rough appearance, the wool in places being stuck together in greasy masses. The mites are most abundant around the edges of an infested patch, and increase very rapidly. The eggs hatch in two or three days, and in fifteen days they become mature. The female lives for several weeks and deposits a great number of eggs, commonly in patches of about twenty each.

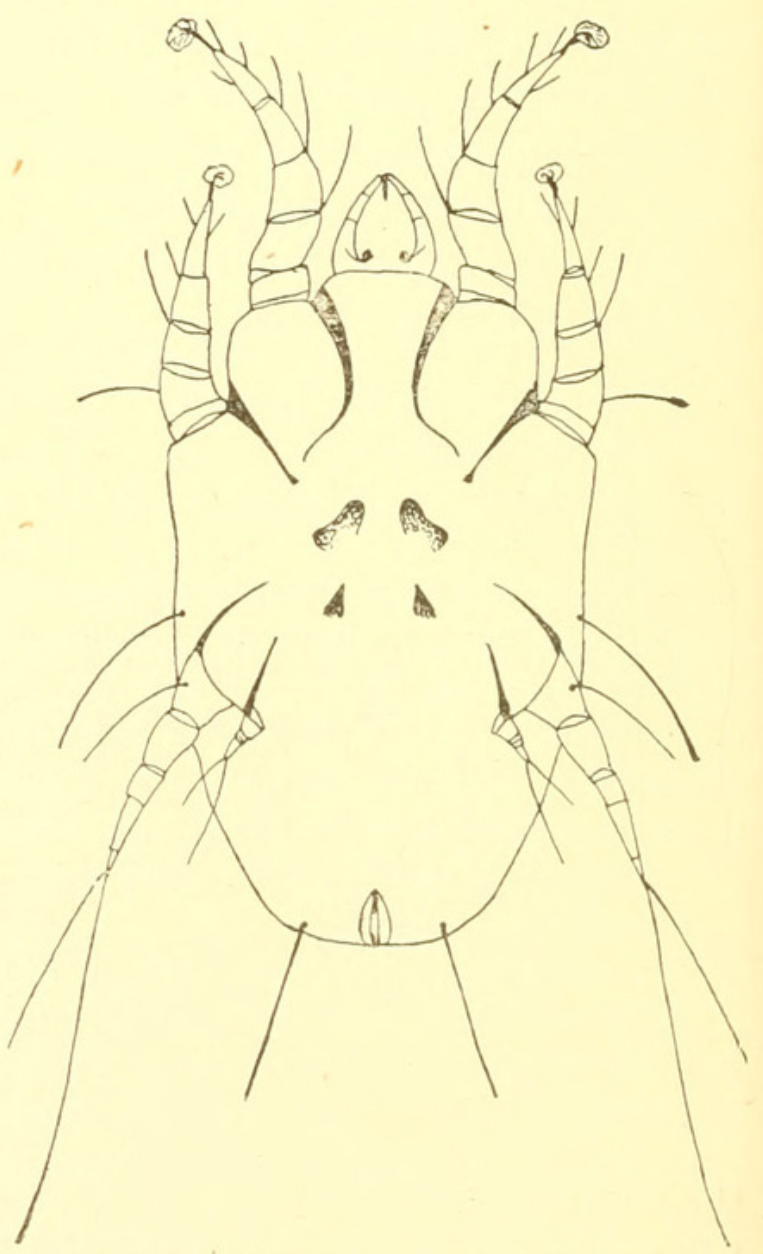

Fig. 186.-Otodectes CyNotis, Female.

By rubbing against posts, trees, and fences wool containing mites and egg's is removed which may infect healthy sheep rubbing against the 
same places from other causes. The loss is usually heaviest in autumn and early winter. Sheep if not treated may soon become so enfeebled through fatigue and lack of rest as to die. The best remedy is to dip the sheep in some poisonous solution. Various dips are in use, mostly based on tobacco, sulphur, tar, or lime. The famous Rutherford dip, which has been very successful, is prepared by using one pound of tobacco, one pound of sulphur, and four gallons of water. The tobacco is steeped for some time in the water. the sulphur is added to this tobacco water, and then the mixture is diluted by the requisite amount of water. It is best used warm. It is customary to give another dip about six or eight days after the first, so as to catch the mites that have hatched since the first dip was applied. Gillette has used an per cent kerosene emulsion, and considers it

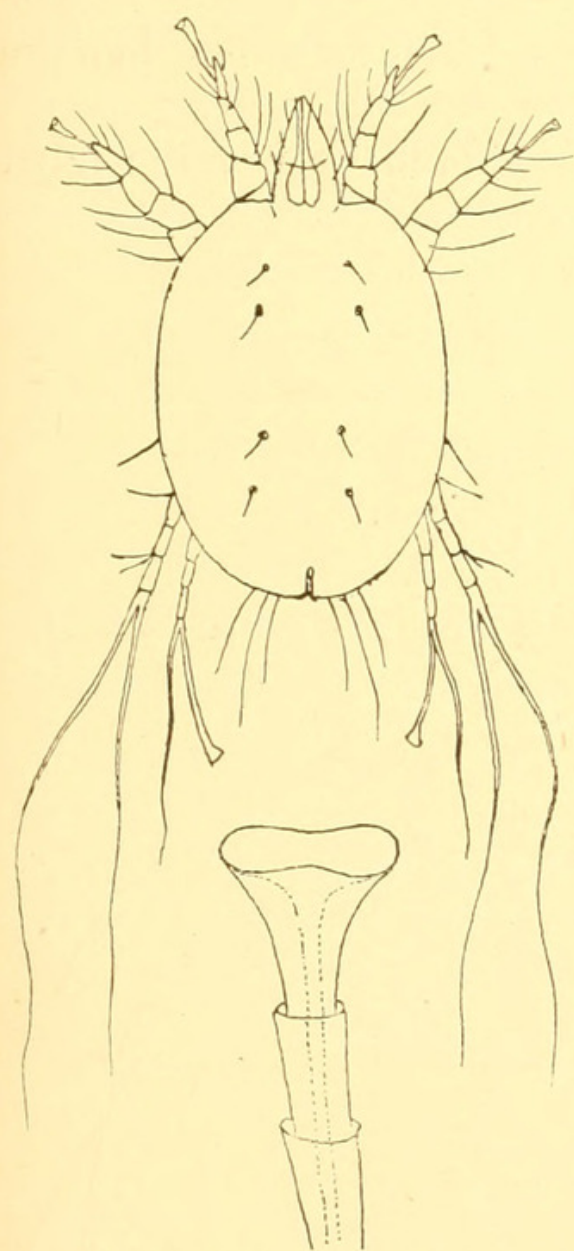

Fig, 188.-PSOROPTES COMMUNIS, VAR. OVIS, FEMALE AND CARONCLE ENLARGED.

they have convulsions or fits. The purulent matter should be carefully removed, and the ears bathed and injected with olive oil containing one-tenth part of naphthol.

The genus Cnemidocoptes contains a number of species that occur on various birds, including poultry. Some live at the base of the 
feathers, others produce a crust of loosened tissue and dead skins similar to that of Norwegian itch. They may begin on the comb or

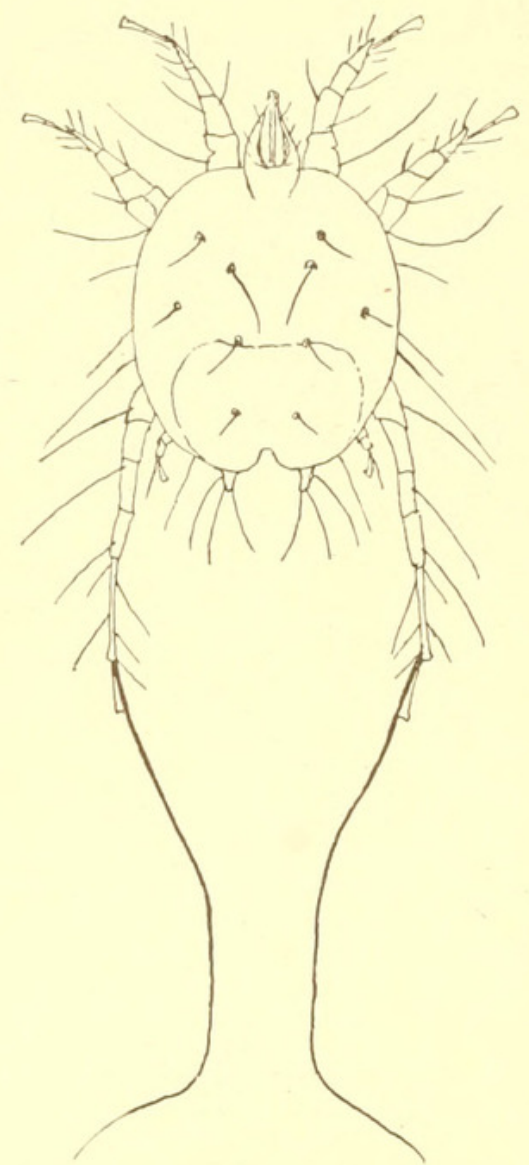

Fig. 189.-Psoroptes COMMUNis, VAR. OVIS, MALE. skin of the feet, but gradually spread down the neck or up the legs. The species are all short and broad, with short legs and with very few hairs above, and these small. They give birth to living six-legged larvæ, which, however, appear to have hatched from eggs while in the body of the parent. C. mutans Robin is the itch mite of domestic fowls, at times a very serious pest. The disease it produces is known as "scaly leg," since the mites are most abundant on the legs. The best remedy is to soak the legs in warm soapy water until the crusts are loosened; then apply sulphur ointment. Bathing the affected portions in a 5 to 10 per cent solution of creolin is also a good remedy; the treatment should be repeated in a few days. The infested fowls should be isolated until cured. Another species, C.gallinæ Railliet, occurs at the base of the feathers, where it burrows and produces a mass of loosened scales. The itching induces the hens to pluck their feathers.

\section{Family CYTOLEICHID E.}

This family (Sarcoptides cysticoles of Mégnin) contains but two species-Cytoleichus (formerly Cytodites) nudus and Laminosioptes (often Symplectoptes) cysticola-both of economic importance. They were discovered in 1870 by Francesco Vizioli in the common fowl. Both are very small, soft-bodied mites, much like a Sarcoptes, but differing in having the vulva longitudinal and the smaller and less prominent mouth-parts. The legs are very short, the anterior pairs the larger, and all separate at base. The tarsus ends in a long sucker, but without claws. Laminosioptes sometimes occurs on the skin, but often bores into the subcutaneous tissue, where it gives rise to a calcareous cyst. Cytoleichus

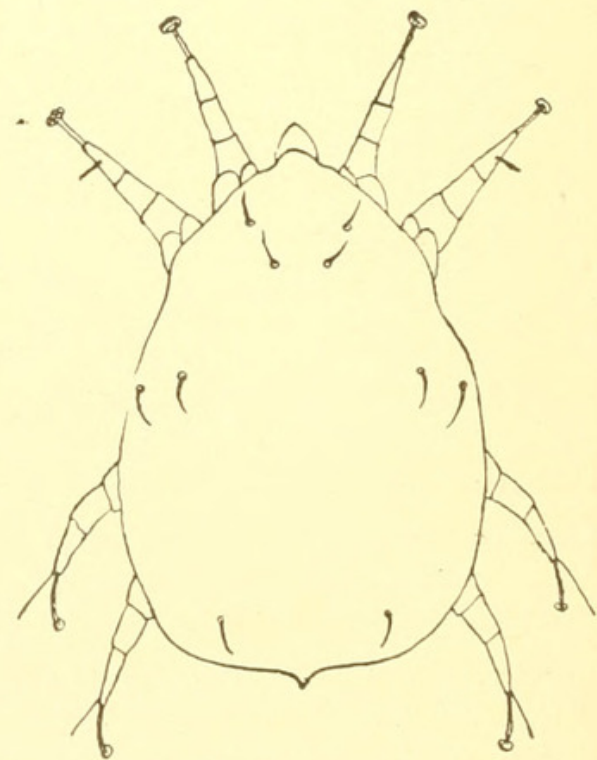

Fig. 190.-CYToleichus NUdUS.

has been found in various parts of the common fowl, but most commonly in the air-passages and air-cells. Here its presence in 
great numbers may produce asphyxia in the host. It has also been suspected of producing peritonitis and enteritis, but Wilcox has shown its presence in perfectly healthy fowls, so that it is not certain that the mite necessarily produces any disease. The mites are probably taken up by the fowl with its food. Although apparently clumsy the mite is exceedingly active, and can penetrate most of the tissues of the body. It is viviparous, and the young at birth have six legs. They also occur on most of the birds related to or associated with poultry. Both species have been taken in this country, but Cytoleichus is the more common.

\section{Family ERIOPHYIDA.}

The members of this family, long known as Phytoptidæ, ${ }^{a}$ are among the most curious forms of the Acarina. They are extremely minute, but make up by their great numbers. They are strictly plant-feeders, and many of them cause galls, fuzzy spots, or other deformations on plants. These galls, unlike many insect galls, have an opening through which the mites may pass. The adult mite has but four legs, all near the anterior part of the body; the pos-

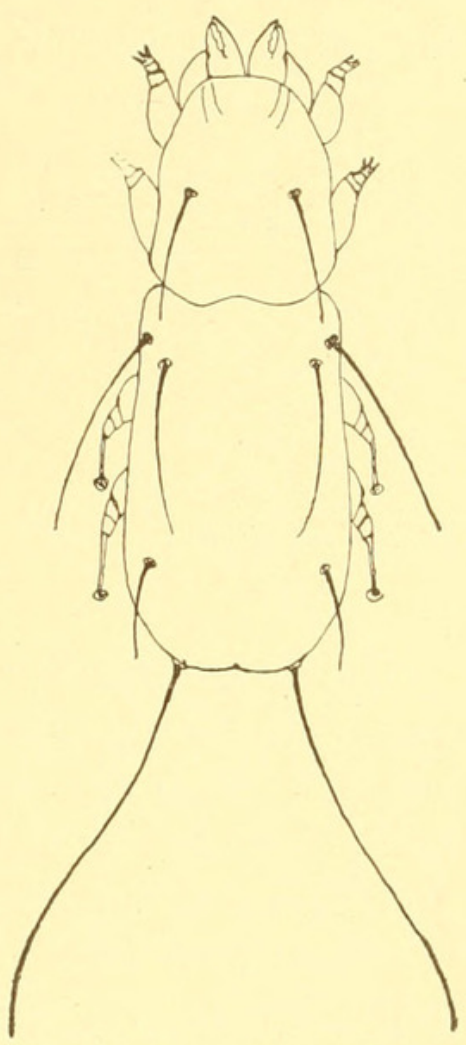

Fig. 191.-LAMinosioptes CYSTICOLA. terior pairs being wholly lacking or represented by fine hairs. The body is divided into two parts - the anterior, short and broad, is the cephalothorax; the posterior, long, tapering, and multi-annulate, is

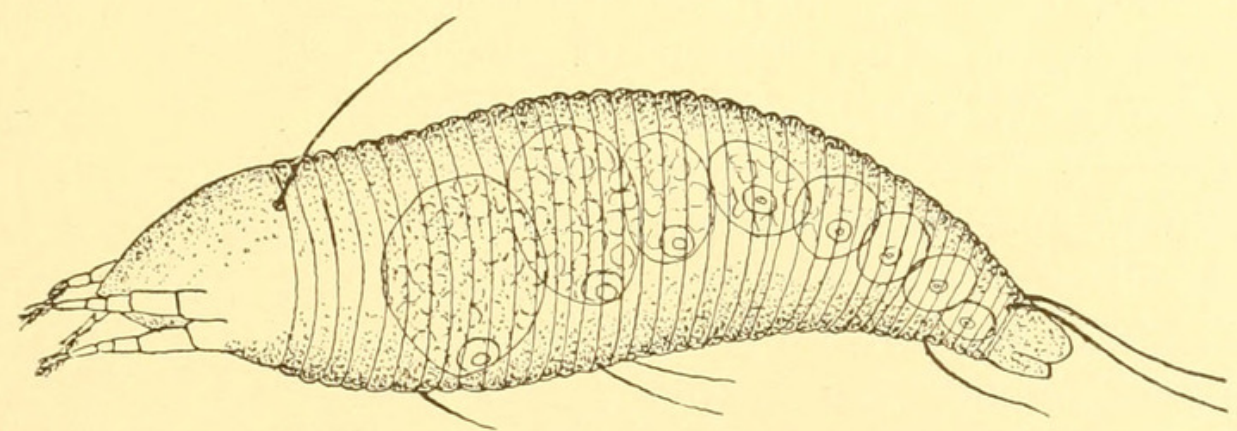

FIG. 192.-ERIOPHYES SP., SIDE VIEW

the abdomen. There is a pair of free three-jointed palpi, and between them the rostrum, from which may project the needle-like mandibles.

$a$ The change of name of this well-known group of mites seems inevitable, although much to be deplored. Eriophyes Siebold has a year's priority over Phytoptus Dujardin. But Siebold did not carefully study these mites at all, and supposed them to be immature creatures. Dujardin recognized their true nature and made many careful observations upon them. European authors, however, have recently adopted Eriophyes. 
Near the base of the abdomen, beneath, is the genital opening, the female epigynum being quite large and prominent; the male epiandrum is much smaller. At the apex of the abdomen is a truncate piece, the telson, from which arise two long hairs, and sometimes other shorter ones. There are also a few other hairs on the body. At the tip of the abdomen is a sucker, which can be extended or retracted at the will of

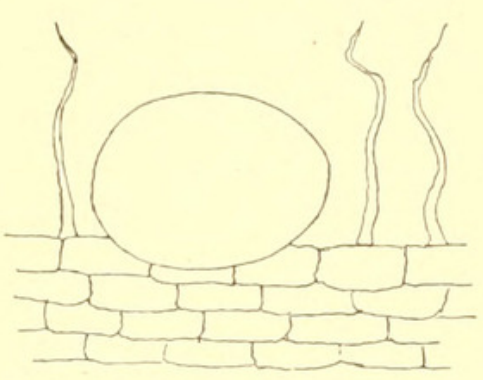

FIG. 193.-EGG OF AN ERIOPHYES IN GALI the animal. The leg's are five-jointed, short, and end in a single tarsal claw, beneath which is a plumose hair, known as the "feather hair.' The cephalothorax often shows various lines or ridges. The number of rings or annulations on the abdomen varies according to the species, and in some forms there are more divisions above than below. In size few of the Eriophyidx reach one-hundredth of an inch, and many are not half as long.

The Eriophyidæ have had a checkered history. The early botanists, unable to see the minute creatures, supposed that the galls and fuzzy spots were fungi, and so described them, the genus Ceplatoneon being founded on distinct galls, Tolvolifex on rolled edges of leaves, and Erineum and Phyllerium on the fuzzy patches.

Dugès in 1832, who was the first to carefully look into these galls, supposed that the mites were immature, since they had but two pairs of legs. He saw the eggs, but supposed that the adult mite had come in the gall to lay the egg's and then went out to deposit eggs elsewhere. In 1851 Dujardin examined some galls, found the mites, and noticed within some of these, objects which he took to be eggs. Therefore he believed these mites to be adults, and named them Phytoptus. A few years later Scheuten examined the pear-leaf blister, found the mites, and decided that they were immature forms, and that the full-grown creature was an eight-legged mite that he found associated with them. This supposed adult he figured and proves to be a Gamasid, which

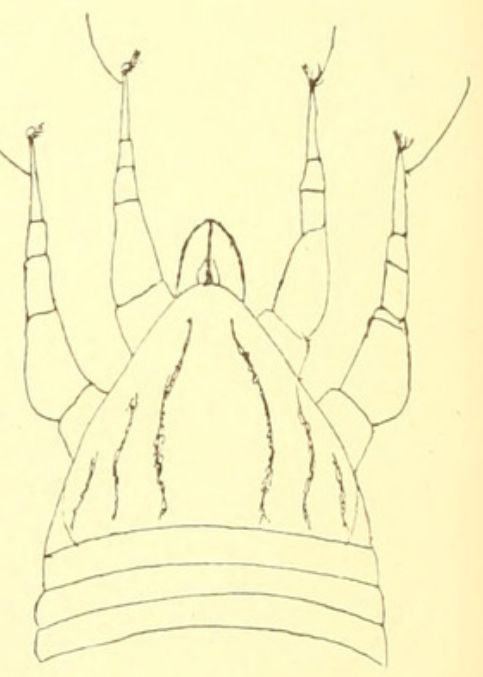

Fig. 194.-ERIOPHYES GOSSYPII, ANTERIOR PART OF BODY. was doubtless feeding on the Eriophyes. Since then many observers have examined these mites and confirmed Dujardin, that they are adult and constitute a separate group of Acari.

The deformations produced by mites on plants have been called acaro-cecidii. Nearly all such deformations are produced by members of this family. The relation of the mite to the gall or erineum is not fully known. An erineum is practically a dense mass of deformed 
hairs. These hairs are usually thickened and twisted, and the whole mass is of an even height. The mites live among these deformed hairs, sucking the juices of thè leaf. As the juice becomes exhausted the erineum becomes reddish or rusty brown in color, and is a very prominent object. At this stage, when the erineum is most easily noticed, one is apt to find few if any mites, as they have left for fresh pastures.

The galls may be on either surface of the leaf, though commonly above. The form is quite characteristic of the species, though there is usually some variation. These galls always have an opening through which the mites can pass. This character will distinguish these galls from those of Diptera and Hymenoptera, but not from Homopterous galls. The opening is often very small and concealed by tufts of hairs. Within, the gall is often partly filled up with folds and projections, and sometimes

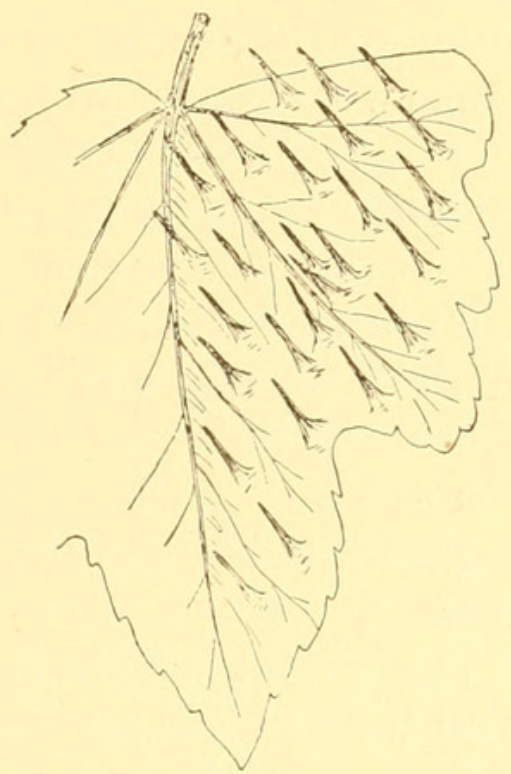

FIG. 195.-NAIL-GALLS OF AN ERIOPHYES. with hairs. In color the gall is at first like the leaf, but gradually turns yellow or reddish, and then brown or black. Sometimes the gall covers a great deal of space, but does not swell up much, in appearance much like a blister.

Galls are formed while the leaf is growing rapidly. It is supposed that the puncture of the plant-cells by the mite

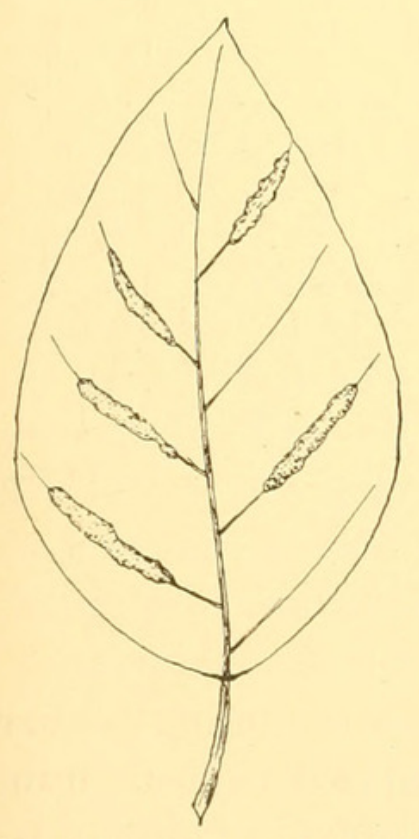

FIG. 196.-RIB-GAIJS OF AN ERIOPHY ES. induces an increased flow of sap in that direction, which causes the spot to grow faster than the surface around it, so that this spot must swell up in the form of a gall. This, however, does not account for the diversity of form of the galls, and why each gall is characteristic of the mite that made it. Some species of Eriophyidæ live in plant-buds, and their feeding prevents the opening of the bud, which after a time dries up and dies. With other species the buds swell to a great size, but never open. Other mites produce a curling or rolling of the edge of the leaf, or a slight folding of the surface. Some live on the surface of fruits, as the orange-rust mite. A few species produce galls or excrescences on twigs, especially near the base of terminal buds. The diseased condition produced by these mites has been termed phytoptose or erinose.

The eggs of the Eriophyidæ are laid upon the surface of the leaf. 
They are attached singly, are nearly spherical in shape, and pale yellowish or grayish in color. The eggs are quite large as compared with the mite. The young, at birth, are helpless and without tarsal appendages, but soon molt and obtain them. The mites can move quite swiftly, considering their size, and sometimes they spread over a tree with wonderful rapidity. The anal sucker aids them in holding on to a surface, but not in locomotion. They molt four times, it is said, before becoming adult, but pass through no changes in structure, except the development of the genital apertures. At each molt there is a resting period when the mite is within its old and now loose skin. With the drying up of the food-plant in the fall the mites seek winter quarters within the buds or beneath the bud-scales. Sometimes, doubtless, they winter under pieces of bark. When in a bud they begin to feed on the leaf, and produce the gall before the bud is fully open.

The Eriophyidx have usually been supposed to have some affinity with the Sarcoptidx; however, I think they show far more relation to the Tarsonemidæ and Tyroglyphidæ. There is not much diversity of form in the family, and generic classification is based on few and rather simple characters. Quite a number of galls have been collected in the United States, but the mites have not been studied except by Professor Garman, who described a few species. Several European acarologists have carefully studied these mites in recent years, but the work of Alfred Nalepa, of Linz, has been preeminent.

The better-known genera maybe separated as follows:

1. Number of abdominal rings on dorsum and venter nearly equal........ Eriophyes Number of abdominal rings on venter nearly twice as many as on dorsum . . . . 2

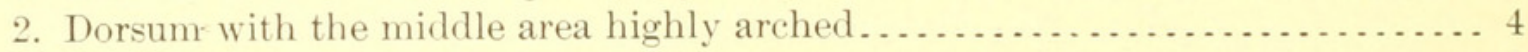

Dorsum of an even curve ...................................... 3

3. End piece of abdomen plainly separated ....................... Anthocoptes

End piece of abdomen not plainly separated ................... Phyllocoptes

4. Some of the dorsal abdominal rings extend backward spine-like on the side

Oxypleurites

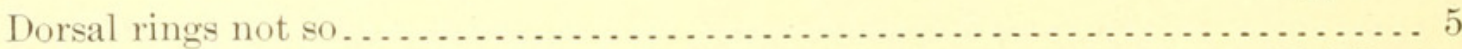

5. Dorsum of abdomen with two longitudinal furrows . . . . . . . . . Epitrimerus

Dorsum without furrows . . . . . . . . . . . . . . . . . . . . . . . Tegonotus

The species, so far known from the United States, have been referred to Erioplyyes, but several of the other genera occur here.

Most notable of all our species is the pear-leaf blister-mite, Eriophyes pyri, an European species whose introduction into this country seems to have been accomplished before 1870 . It is now widely distributed throughout most of the pear-growing region, and also occurs in Australia. It appears to be more injurious in this country than in Europe, and in some cases it is so abundant that the tree sheds nearly all its leaves before the fruit is ripe. The mites pass the winter in the buds, and begin to feed before the leaves are 
unrolled. They form red-blister-like spots nearly one-fourth inch across. These spots become green by June, and then turn brown, and the tissue becomes hard and corky. The opening is on the

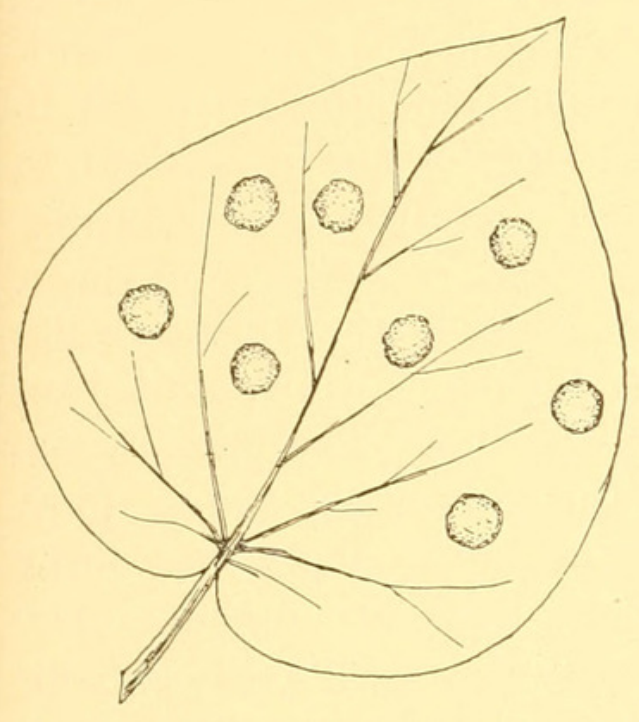

FIG. 198.-ROUND-GALLS OF AN ERIOPHYES.

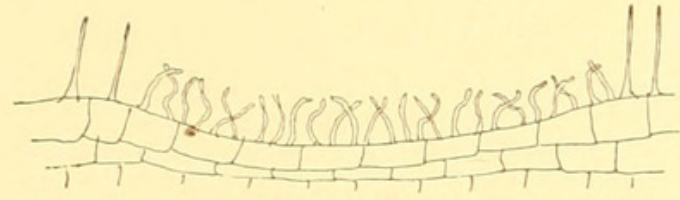

Fig. 197.-SECTION OF AN ERINEUM ON LEAF.

under side. As mites often start galls close together, they soon coalesce and form large blotches. Professor Slingerland has found that they can be practically exterminated by spraying the trees in winter with kerosene emulsion diluted with from five to seven parts of water. This mixture reaches the hibernating mites in the buds, and kills them there.

Another species of considerable economic importance is Eriophyes oleivorus Ashmead, the rust mite of the orange and the silver mite of the lemon. It occurs in Florida and California, and lives on both leaves and fruit. On the foliage the mite causes the leaves to become curled and lose their gloss. On the fruit of the orange the mite produces a hardening of the rind, which becomes brownish in color. The infested orange, although injured in appearance, is better able to stand long shipment, and more juicy than the clean fruit. Upon the lemon the mites cause the rind to become whitened or silvered. The fruit is better for shipment, but the rind is injured for commercial purposes. The circular eggs are deposited on the leaf or fruit, generally in clusters. They hatch in five to ten days. It takes about two weeks to reach maturity. Its food is the essential oil, found in the epidermal cells. Mr. Hubbard, who studied this mite more carefully than anyone else, estimated that there may be 75,000 mites and eggs on a single leaf. The

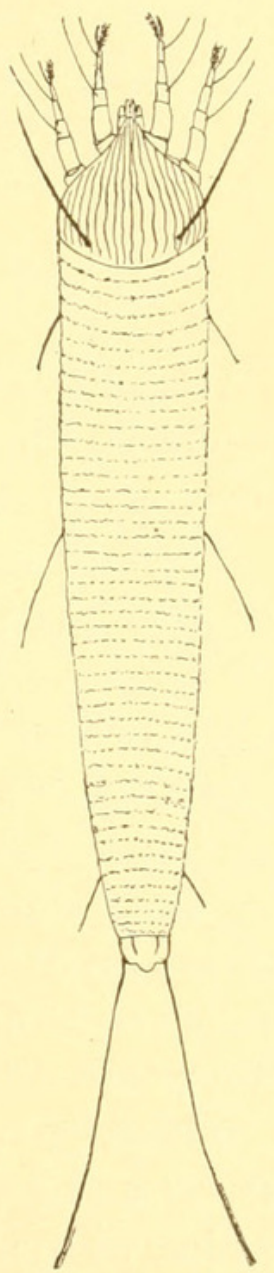

Fig. 199.-ErioPHYES VITIS. best remedy is flowers of sulphur; this may be applied dry, or mixed in with a spraying solution, as kerosene emulsion.

Another injurious species in this country is the plum-twig gall mite, Eriophyes phloocoptes Nalepa (also known as Cecidoptes pruni Amerling). 
It is an European species that has been-imported into this country in recent years. The mites form small subspherical galls at the base of the buds. A cluster may surround the twig. The mites hibernate within the galls, leaving them in the spring to form new ones. The galls are at first plump and smooth, but later become dry and wrinkled, and sometimes crack. Pruning and burning the infested twigs in winter will keep the mites in check. An application of sulphur in the spring, when the mites are active, will, doubtless, destroy many of them.

The black-currant gall mite, Eriophyes ribis, is very injurious to the currant in England. They penetrate the buds, causing them to swell, and badly infested buds die before opening. The mites breed

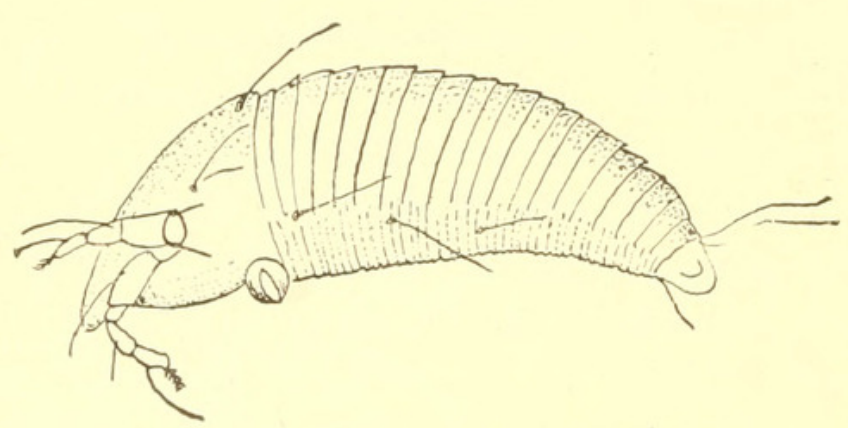

Fig. 200.-PHLEOCOPTES SP., SIDE VIEW. throughout the year. They migrate in the spring when the buds are opening, and may be destroyed at this time by a wash of soft soap and sulphur. It has been observed that this species can stand upright and even jump into the air and be carried some distance by the wind.

In California the Eriophyes vitis Landois often seriously injures the leaves of the grape. The mites produce an erineum on the under surface of the leaf that causes swellings on the upper surface.

The mites pass the winter in the buds or under the bark of the vine. Applications of sulphur will destroy this as well as other species of Eriopliyes. Walnut trees in California are also affected by an Eriophyes which produces blister galls and erineum on the leaves. It appears to be the E. tristriatus Nalepa, of Europe, which has similar habits.

One of our most common species is Eriophyes quadripes Shimer, which produces roundish galls on the leaves of the soft maple. The galls are at first green, but later become purplish and finally black. There are often several hundred galls on one leaf.

Eriophyes gossypii Banks occurs injuriously upon cotton in Montserrat and some other West Indian islands. The mites produce galls which were so numerous as to cover many leaves with a mass of irregular, roughened swellings, curled and distorted. The damage in places was so severe that the cotton had been thrown into the sea. The galls within are densely clothed with long hairs.

Two species are very injurious to the leaves of the tea plant in India and Ceylon, and no good remedies have yet been devised for them. 


\section{Family DEMODECID E.}

To this family belongs but one genus, Demodex, found in the sebaceous glands and hair-follicles of various mammals, including man. The mite is very small, elongate, with eight short, three-jointed legs, and in front a short, median, sucking rostrum. The palpi are appressed to the under surface of the rostrum. The abdomen is tapering, transversely striate above and below, and rounded at tip. There is a large vulva situate at base of the abdominal venter. The egg is fusiform, and gives birth to a hexapod larva, which moults and becomes octopod. Two more moults brings it to maturity. The nymphs greatly resemble the adults, and the sexes differ but little.

D. folliculom Simon, the species found on man, was long supposed to be the cause of "blackheads" and comedomes on the face. Medical authorities claim that the mites do not cause "blackheads," and that they occur in healthy as well as diseased follicles. The mites migrate over the skin to enter new glands. They occur on children as well as adults, and in all parts of the world.

D. phylloides Csokor has been found in Canadian swine, causing white tubercles on the skin, from the size of a pin-head to that of a pea. Within each of these abscesses a number of the Demodex were crowded together. They did not appear to affect the health of the animal. D. bovis Stiles was

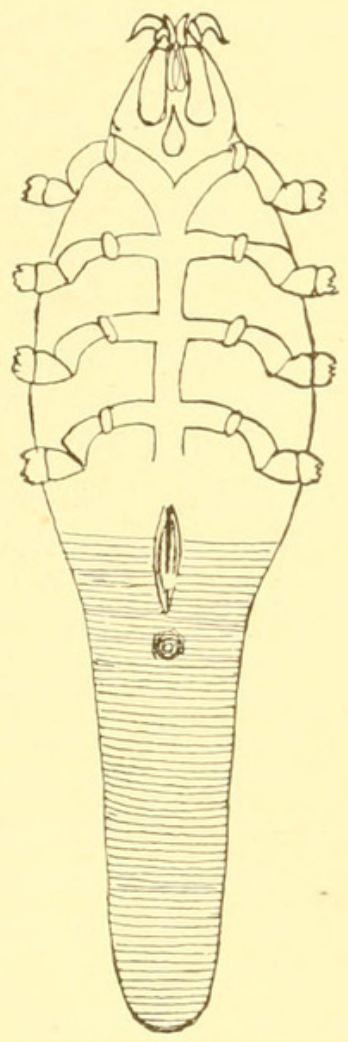

Fig. 201.-DEMODEX FOLLICULORUM. recorded from hides of cattle in the United States. They formed swellings, about the size of a pea, on the skin. Within each there were a great number of mites. The presence of these tubercles lessens the value of the hide to a considerable degree. Herds could douftless be cleaned by dipping in some liquid similar to the sheep and cattle dips now in use against other mites.

\section{LIST OF WORKS USEFUL IN THE STUDY OF AMERICAN ACARINA.}

N. Banks. Some new American Acarina. Trans. Amer. Entom. Soc., XXI, 1894, pp. 209-222.

1895 , pp. 1-16.

- The red Spiders of the United States. Bull. no. 8, Techn. ser., Div. Entom., U. S. Dept. Agric., 1900 , pp. $65-77$.

A. Berlese. Acari, Myriopoda et Scorpiones hucusque in Italia reperta. Patavia, 1880. [Issued in mixed fascicles; the parts on Prostigmata (Trombidiidæ), Gamasidæ, Oribatidæe, and Sarcoptoidea are finished.] 
G. Cinestrini. Prospetto dell' Acarofauna Italiana, Padova, 7 parts, 1885-1897.

- and P. Kramer. Demodecidæ et Sarcoptidæ. Das Tierreich, 7 Lief., 1899, pp. 193.

E. Claparède. Studien an Acariden. Zeitschr. f. wiss. Zool., XVIII, 1869, pp. 445546,11 pls.

A. L. Donnadiev. Recherches pour servir à l'histoire des Tétranyques. Ann. Soc. Linn. Lyons, XXII, 1875, pp. 29-180, 12 pls.

A. Dugìs. Recherches sur l'ordre des Acariens. Ann. Sci. natur. (2), I, 1836, Zool., pp. $18-63$.

E. Ehlers. Die Krätzmilben der Vögel; Ein Beitrag zur Kenntniss der Sarcoptiden. Zeitschr. f. wiss. Zool., XXII, 1873, pp. 228-253, 2 pls.

H. F. Fürstenberg. Die Krätzmilben der Menschen und Thiere. Leipzig (Folio). 1861, 240 pp., 15 pls.

H. Garman. The Phytopti and other injurious plant-mites. 12th Rept. State Entom., Illinois, 1883, pp. 123-143.

P. Gervais. Histoire nat. des Insectes Apterès, III, Paris, 1844. pp. 132-288.

(i. Haller. Zur Kenntniss der Tyroglyphiden und Verwandten. Zeitschr. f. wiss. Zool., XXXIV, 1880, pp. 255-295, 3 pls.

- Die Milben als Parasiten der Wirbellosen, insbesondere der Arthropoden. Halle, 1880, $90 \mathrm{pp}$.

L. Karpelles. Beiträge zur Naturgeschichte der Milben. Berl. Entom. Zeitschr., 1884, pp. 1-34.

F. Komsike. Die Nordamerikanische Hydrachniden. Abh. Verein Bremen, XIII, 1900, pp. 167-276.

P. Kramer. Beiträge zur Naturgeschichte der Milben. Archiv. f. Naturgesch., XLII, 1876, pp. 28-45.

- Zur Naturgeschichte einiges Gattungen aus der Familie der Gamasiden. Archiv. f. Naturgesch., XLII, 1876, pp. 46-105, 2 pls.

- Die Familie der Bdelliden. Archiv. f. Naturgesch., XLII, 1876, pp. 183-196, 1 pl.

- Grundzüge zur Systematik der Milben. Archiv. f. Naturgesch., XLIII, 1877, pp. $215-248$.

P. MÉgnis. Mémoire sur l'organization et la distribution zoologique des Acariens de la famille des Gamasides. Journ. Anat. et Physiol., 1876, pp. 288-336, 2 pls.

- Mémoire sur les Métamorphoses des Acariens en général, et en particulier sur celles des Trombidions. Ann. Sci. Natur. (6), IV, 1876, pp. 20, 2 pls.

— Monographie de la tribu des Sarcoptides Psorique. Rev. et Mag. Zool. (3), V, 1877, pp. 46-213; 7 pls. in VI, 1878.

- Mémoire sur les Cheylétides parasites. Journ. Anat. et Physiol., 1878, pp. 416-441, 2 pls.

_ Les Acariens parasites du tissu cellulaire et des réservoirs aériens chez les oiseaux. Journ. Anat. et Physiol., 1879, pp. 123-153.

_ Les parasites et les maladies parasitaires. Paris, 1880, 478 pp., 26 pls.

A. D. Michael. British Oribatidæ. Ray Soc., I, 1883, 333 pp., 29 pls.; II, 1887, 324 pp., 31 pls.

— The Hypopus question, or the life-history of certain Acarina. Journ. Linn. Soc., Zool., XVII, 1884, pp. 371-394, 1 pl.

— British Tyroglyphidæ. Ray Soc., I, 1901, 291 pp., 12 pls.; II, 1903, 183 pp., 17 pls.

Oribatidæ. Das Tierreich, 3. Lief., 1898, 93 pp.

R. Moniez. Notes sur quelques espèces de Tyroglyphides qui vivent aux dépens des matières alimentaires et des produits pharmaceutiques. Revue Biol. Nord France, VI, 1894, pp. $442-460$. 
H. A. Mongan. Ticks and Texas fever. Bull. No. 56, La. Agric. Exp. Station, 1899, pp. 14 , pls. 9 .

A. Murray. Economic Entomology, Aptera. South Kensington Museum Science Handbooks, London, 1897, pp. 93-374.

A. Nalefa. Beiträge zur Systematik der Phytoptiden. Sitz. Akad. Wien, Math.Natur. Cl., XCVIII, 1889 , pp. 112-156, 9 pls.

Zur Systematik der Gallmilben. Sitz. Akad. Wien, Math.-Natur. Cl., XCIX, 1890, pp. 40-69, 7 pls.

— Eriophyidæ (Phytoptidæ). Das Tierreich, 4 Lief., 1898, 74 pp.

G. Neumann. Révision de la famille des Ixodidés. Mém. Soc. Zool. France, 1896, pp. 1-44; 1897, pp. 324-420; 1899, pp. 107-294.

H. Nicolet. Histoire naturelle des Acariens qui se trouvent aux environs de Paris. Archives du Muséum d'hist. nat. de Paris, VII, 1854-55.

E. Nordenskiöld. Beiträge zur Kenntnis der Morphologie und Systematik der Hydrachniden. Acta Soc. Sci. Fenn., XXIV, No. 5, 1899, 74 pp., 2 pls.

C. Nörner. Beitrag zur Kenntniss der Milbenfamilie der Dermaleichiden. Verh. zool.-bot. Ges. Wien, 1883, pp. 91-106, 2 pls.

H. Osborn and L. M. Underwoon. Preliminary list of the species of Acarina of North America. Can. Entom., 1886, pp. 4-12.

A. C. Oudemans. List of Dutch Acari. 7 parts. Tijdsch. voor Entom., XXXIX and XL, 1896-97; and supplements, XLIII to XLV, 1900-1902.

R. Piersig und H. Lohmans. Hydrachnidæ und Halacaridæ. Das Tierreich, 13 Lief., 1901, pp. 336.

C. Robin et P. Megnin. Mémoire sur les Sarcoptides plumicoles. Journ. Anat. et Physiol., 1877, pp. 209-248; 391-429; 498-520; 629-656; 10 pls.

D. E. Salmon and C. W. Strles. The cattle ticks of the United States. 17th Rept. Bureau Animal Industry, U. S. Dept. Agric. (1902), pp. 380-491, 257 figs.

E. Trouessart. Revue synoptique de la famille des Halacaridæ. Bull. Sci. France, Belgique, XX, 1889, pp. 225-251.

- Considérations générales sur la classification des Acariens. Revue Sci. Nat. de l'Ouest, Paris, 1891, pp. 289-308; 1892, pp. 20-54.

J. B. Tyrrell. On some Canadian ectoparasitic Sarcoptidæ. Journ. Ottawa Field Nat. Club, III, 1882 ; pp. 43-48, 1 pl.

R. H. Wolcotт. On the North American species of the genus Atax. Trans. Amer. Micr. Soc., XX, 1899, pp. 193-259, 5 pls.

- On the North American species of the genus Curvipes. Trans. Amer. Micr. Soc., 1901; pp. 201-256, 5 pls.

On the North American species of Limnesia. Trans. Amer. Micr. Soc., 1903, pp. 139-161, 2 pls. 



\section{INDEX.}

Abrolophus $=$ Rhyncholophus

Acanthonotus $=$ Oxypleurites

Acarellus $=$ Hypopus

Acariasis ...

Acaro-cecidii

Achorolophus = Rhyncholophus .

Actineda $=$ Anystis

Adobe tick.

Agaue ...

Aleurobius

Allanalges. . .

Alloptes . .

Alycus.

Amblyomma...$\ldots \ldots \ldots \ldots \ldots \ldots \ldots \ldots \ldots \ldots \ldots \ldots$

Ambulacrum

Ameronothus = Scutovertex

Ammonia $=$ Cyta

Analges ....

Analgesidæ.

Analloptes $=$ Pteralloptes

Ancystropus.

dngelia $=$ Nothrus

Angelitos...

Antennophorus

Anthocoptes.

Anurania $=$ Arrenurus

Apectolophus $=$ Rhyncholophus .

Areola.

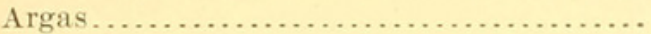

Argasidæ

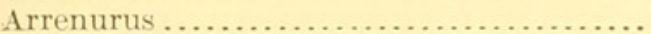

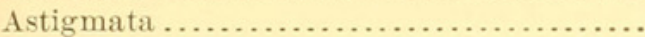

Astoma. . .

Atax.

Atractides

Aturus. .

Bdella ................

Bdellidæ

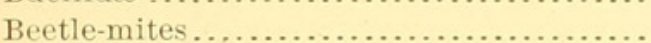

Belba $=$ Oribata

Bird-mites.

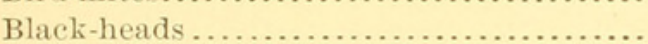

Boophilus ..............................

Bradybates $=$ Thyas

Brain . .

Brevipalpus $=$ Tenuipalpus

Bryobia

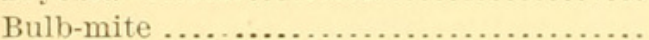

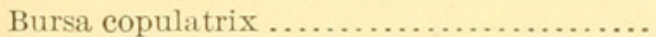

Cæculidæ.

Cæculus

Cæpophagus $=$ Rhizoglyphus.

Caligonus ...
Page.

Camerostome

Campognatha $=$ Hygrobates

Canestrinia......................... 87

Page.

Canestrinidæ ........................ 86

Caparinia ........................... 99

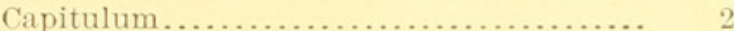

Carabodes ............................ $\quad 72$

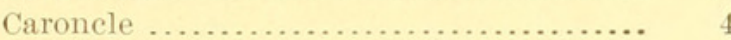

Carpais $=$ Gamasus

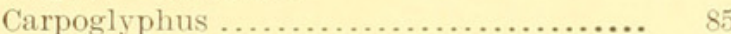

Cattle tick .......................... 47

Cecidoptes $=$ Eriophyes.

Celæno $=$ Trachytes

Celænopsis ......................... $\quad{ }_{57}$

Celeripes $=$ Pteroptus.

Cellularia $=$ Hypoderas.

Cephaloneon .......................... 102

Cepheus $=$ Notaspis.

Cheyletia............................ 19

Chevletidæ............................ 17

Cheyletiella ............................ 19

Cheyletus ............................. 19

Chicken-mite........................... 60

Chicken tick ......................... 46

Chirodiscus ............................ 94

Chorioptes ............................ 99

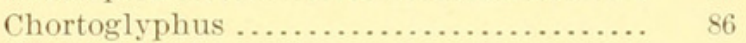

Chrithoptes .......................... $\quad 77$

Chyzeria .......................... 33

Cilliba............................ 68

Claviceps $=$ Galumna.

Cnemidocoptes ....................... 99

Cochleophorus $=$ Neumania

Coloboceras ........................ 41

Criniscansor $=$ Myocoptes.

Crista.................................. 28

Cryptognathus ......................... 28

Cryptostigmata....................... 9

Curvipes $=$ Piona

Cymberemæus......................... $\quad 72$

Cyrtolælaps........................... 57

Cyta ................................ 17

Cytodites $=$ Cytoleichus

Cytoleichidæ .......................... 100

Cytoleichus........................... 100

Damæus $=$ Oribata

Dameosoma $=$ Oribata

Demodex........................... 107

Demodicidæ........................... 107

Deraiophorus........................ 64

Dermacentor ........................... 48

Dermaleichus $=$ Analges .

Dermanyssidæ...................... 59

Dermanyssus ........................... 60

Dermatocoptes $=$ Psoroptes.

Dormatodectes = Psoroptes. 
Dermatophagus $=$ Chorioptes

Dermatoryctes $=$ Cnemidocoptes.

Dermoglyphus.

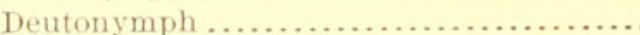

Deutovum ..............................

Dimorphus = Megninia.

Dinvehus...

Discopoma $=$ Cilliba

Disparipes.

Distigmatus $=$ Tetranychus

Diversipes .............................

Dog tick .................................

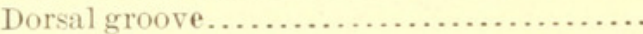

Ductus ejeculatorius

Dugesia $=$ Smaridia

Ear tick

Emeus $=$ Hyletastes

Entozoon $=$ Demodex

Epiandrum ...

Epicrius . . .

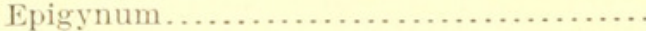

Epistoma ................................

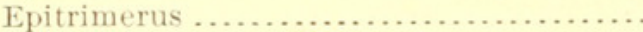

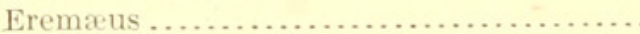

Erineum .................................

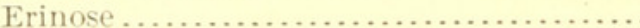

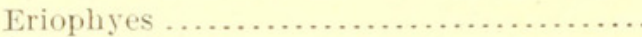

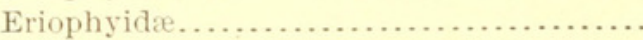

Ervnetes.

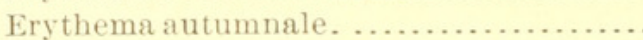

Erythracarus $=$ Erythræus.

Erythræidæ

Erythreus

Eschatocephalus $=$ Hæmalastor .

Eupalopsis..............................

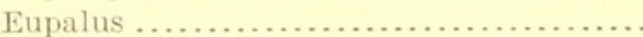

Eupodes .................................

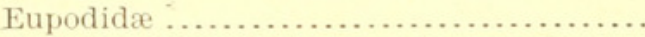

Eusarcoptes $=$ Sarcoptes

Expulsory vesicles.

Eylais

Falculifer

Fedrizzia ..............................

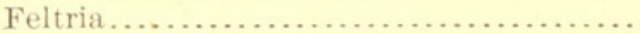

Fowl tick $=$ Chicken tick.

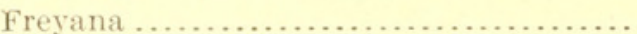

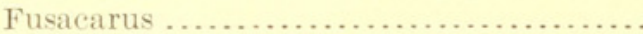

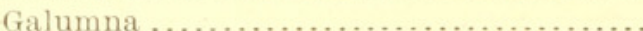

Gamasellus ...............................

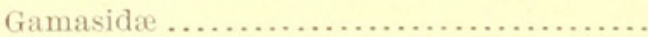

Gamasus.

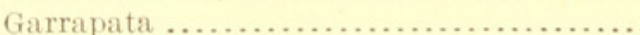

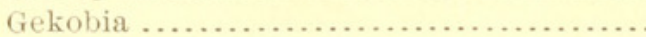

Glyciphagus ...

Glycyborus = Glyciphagus.

Glyphopsis .

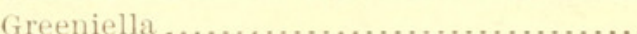

Grocer's itch.............................

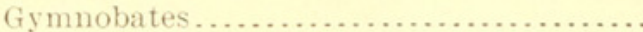

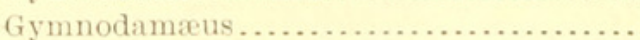

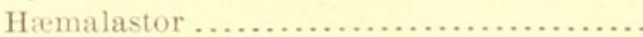

Hæmaphysalis

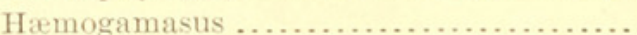

Halacaridæ.
Page.

Halacarus .......................... ${ }_{42}$

Halarachne........................... 61

$90 \quad$ Haller's organ....................... 43

54 Haptosoma = Schizocarpus

8 Harpyrhynchus.

Harvest-mite

Heart-water .

Hemialges = Megninia

Hemisarcoptes

Hericia .

Heteronychus $=$ Tetranychus.

Heteropus $=$ Pediculoides

Histiogaster

Histiostoma ........

Holostaspis = Macrocheles

Homopus = Glyciphagus.

Hoplophora = Hoploderma

Hoplopus $=$ Cæculus .

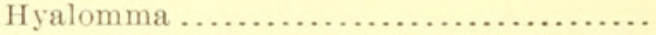

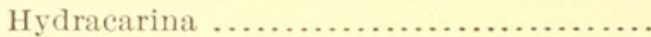

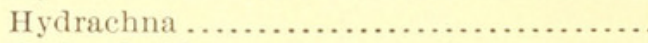

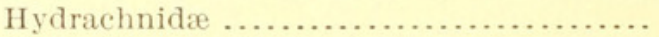

Hydrodroma $=$ Hydryphantes.

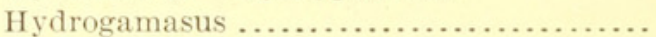

Hydryphantes ........................... 37

Hygrobates .............................. 39

Hyletastes ............................. 57

Hypoaspis = Lælaps.

Hypochthonius.

Hypodectes. . . . n

Hypoderas...

22 Hypostome

Imparipes
Iphiopis ...

Iphis = Hyletastes

Itch-mites

Ixodes

Ixodidæ

Krameria $=$ Pterolichus

Krendowskia...

Labidophorus ............................

Lælaps................................. 58

Lamella ............................... 65

Laminosioptes....................... 100

Lebertia ............................... 38

Leiognathus $=$ Liponyssus.

Leiosoma $=$ Liacarus

Lentungula............................ $\quad 86$

Leptus................................ 31

Liacarus

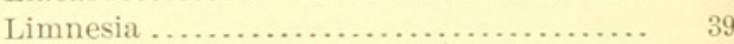

Limnochares ........................ 38

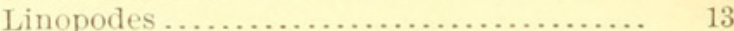

Liodes $=$ Neoliodes .

Liroaspis

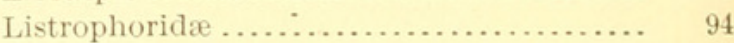

Listrophorus.......................... 94

Lone-star tick ........................ 49

Louping-ill ............................ 49

Macrocheles........................... 58
Liponyssus .............................. 60 
Malignant jaundice.

Page.

Mange. . .

Mediolata $=$ Eupalopsis

Megamerus = Eupodes.

Megapus $=$ Atractides.

Megisthanus.

Megninia...

Mesostigmata.

Metapodia.

Metasternalia

Metastigmata

Miana bug...

Michaelichus $=$ Freyana.

Microcheles $=$ Zercon.

Microlichus

Microspalax $=$ Freyana

Microtrombidium .

Mideopsis

Molgus $=$ Bdella

Monieziella = Histiogaster.

Noubata bug .

Murcia $=$ Galumna.

Myobia

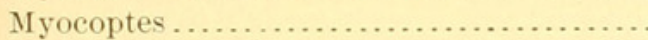

Myrmonyssus.

Najadicola.

Nautarachna

Neoliodes...

Neophyllobius

Neozetes $=$ Serrarius

Neumannia

Nicoletiella. . .

Nodipalpus $=$ Histiostoma.

Norneria $=$ Rhagidia

Notaspis

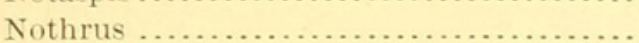

Notoedres

Notophallus

Nycteridocoptes $=$ Prosopodectes.

Nymph . . .

Ocypetus

Olecranon process

Oligonychus $=$ Tetranychus.

Ophiodes

Oppia = Eremæus

Oral tube.

Oribata.

Oribatella

Oribatidæ

Oribatodes.

Oribatula $=$ Eremæus.

Oripoda

Ornithodoros

Otodectes....

Ottonia = Microtrombidium.

Oustaletia $=$ Pterolichus.

Oxypleurites

Pachylælaps..............................

Pajahuellos.

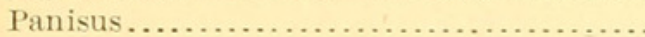

Paralges $=$ Dermoglyphus.

Parasitus $=$ Gamasus .

Pear mite...

Pediculoides......

Pelops

Penthaleus

Proc. N. M. vol, xxviii-04-8
Peplonyssus

Page.

Peritreme .......

Petrobia $=$ Bryobia.

Phthiracarus

Phycobius $=$ Carpoglyphus

Phyllerium .......................... 102

Phyliocoptes ............................ 104

Phyllostoma $=$ Histiostoma.

Physogaster $=$ Pediculoides.

Phytocoptes $=$ Phyllocoptes.

Phytoptose

Phytoptus = Eriophyes.

Picobia .............................. 21

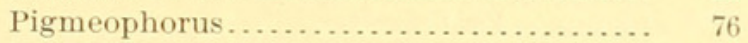

Pinolias ............................. 46

Piona................................ 40

Pneumonyssus ........................ 61

Podapolipus ............................ $\quad 76$

Podocinum ............................ $\quad 56$

Polyaspis ............................. 63

Pontarachna ........................... 37

Porose areas ......................... 42

Porrhostaspis $=$ Gamasus.

Proctophyllodes ....................... $\quad 50$

Prosopodectes ........................... 99

Prostigmata ............................ . 9

Protalges ............................ $\quad 90$

Protolichus $=$ Pterolichus

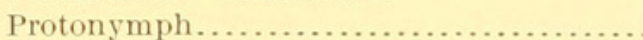

Pseudalloptes $=$ Pterolichus.

Pseudo-stigmatic organ ................. 64

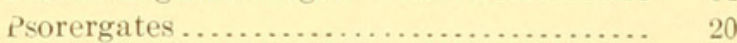

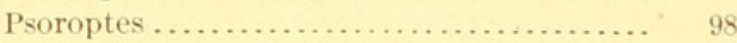

Pteralloptes .......................... 93

Pterocolus $=$ "Trouessartia.

Pterodectes........................... 99

Pterolichus ........................... 91

Pteronyssus........................... 99

Pteroptus ............................. $\quad 59$

Ptilonyssus .......................... 60

Raillietia........................... 57

Raphignathus ........................ 24

Red bug ............................. 31

Red-spiders............................ 23

Red-water.......................... 43

Rhagidia ............................ 14

Rhinonyssus.......................... 61

Rhipicephalus....................... 47

Rhipistoma....................... 48

Rhizoglyphus ....................... 84

Rhombognathus....................... 41

Rhyncholophidæ....................... 28

Rhyncholophus ..................... $\quad 30$

Rivobates $=$ Hygrobates

Rivoltasia ........................... 91

Rouget ............................ 31

Sarcoborus $=$ Harpyrhynchus.

Sarcopterus......................... 20

Sarcoptes........................... 97

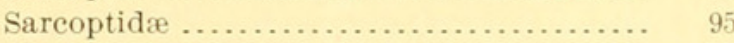

Scabies ............................... 95

"Scaly-leg" ........................... 100

Scaptognathus........................ 41

Schizocarpus .......................... 95

Scirus.................................. 17

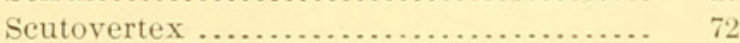


Scyphius $=$ Rhagieia.

Page.

Seiodes

Seiulus $=$ Seius .

Seius

Serrarius

Serrator $=$ Histiostoma

Sheep-scab

Simonea $=$ Demodex .

Siteroptes.

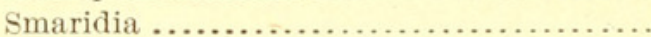

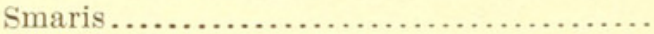

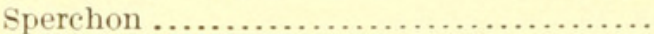

Spermatheca ............................

Sphærogyna $=$ Pediculoides.

Spinturnix $=$ Pteroptus

Steatozoon $=$ Demodex

Steganaspis...

Sternostomum

Stigmæodes = Stigmæus

Stigmæus ... .

Stilochirus $=$ Lælaps

Sugar mite ....

Symbiotes $=$ Chorioptes

Symplectoptes $=$ Laminosioptes.

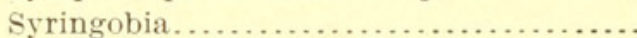

Syringobial stage........................

Syringophilus

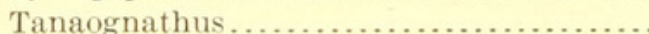

Tarsonemidæ.

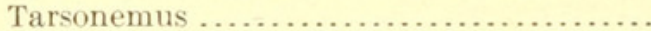

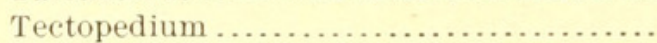

Tegeocranus $=$ Carabodes .

Tegonotus

Tenuipalpus

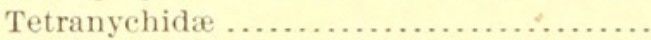

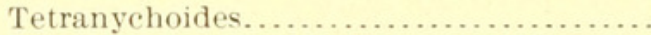

Tetranychopsis.

Tetranychus.

Page.

57

7

57

66

98

41

76

29

29

39

6

39

39
61
Thalassarachna

Thecarthra $=$ Pterolichus.

Thyas................................ 38

Ticks ............................ 42

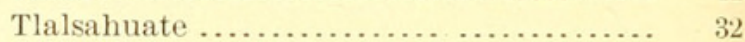

Trachytes ............................ 63

Trichobius $=$ Trichoecius

Trichodactylus $=$ Trichotarsus.

Trichœeius ......................... 94

Trichotarsus......................... $\quad 86$

Trimerus $=$ Epitrimerus .

Tritia $=$ Phthiracarus

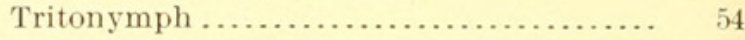

Trombella .......................... 33

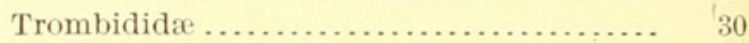

Trombidium......................... 32

Trouessartella $\ldots \ldots \ldots \ldots \ldots \ldots \ldots \ldots \ldots \ldots . \quad 41$

Trouessartia $=$ Allanalges.

Turicata ............................ 46

Tydeus .............................. 14

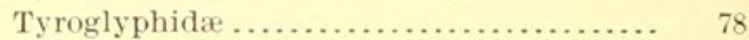

Tyroglyphus.......................... 83

Tyrrellia........................... 38

Unionicola $=\mathrm{A}$ tax

Uropoda ............................. 63

Uropodella ........................... 64

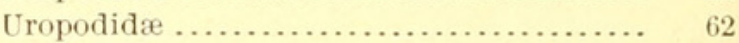

Uroseius .............................. 63

Vasa deferentia ........................ 6

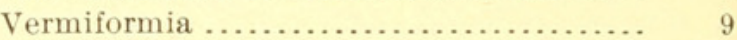

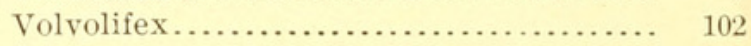

Water-mites .......................... 34

Xoloptes................................ 90

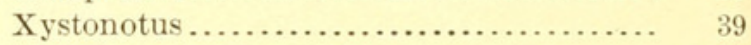

Zereon................................ 57

Zetes = Galumna. 


\section{$2 \mathrm{BHL}$ Biodiversity Heritage Library}

Banks, Nathan. 1904. "A treatise on the Acarina, or mites." Proceedings of the United States National Museum 28(1382), 1-114.

https://doi.org/10.5479/si.00963801.28-1382.1.

View This Item Online: $\underline{\text { https://www.biodiversitylibrary.org/item/52788 }}$

DOI: https://doi.org/10.5479/si.00963801.28-1382.1

Permalink: https://www.biodiversitylibrary.org/partpdf/51055

\section{Holding Institution}

Smithsonian Libraries

\section{Sponsored by}

Smithsonian

\section{Copyright \& Reuse}

Copyright Status: Public domain. The BHL considers that this work is no longer under copyright protection.

This document was created from content at the Biodiversity Heritage Library, the world's largest open access digital library for biodiversity literature and archives. Visit BHL at https://www.biodiversitylibrary.org. 